\title{
WATER-QUALITY ASSESSMENT OF THE KENTUCKY RIVER BASIN, KENTUCKY: NUTRIENTS, SEDIMENTS, AND PESTICIDES IN STREAMS, 1987-90
}

By Kim H. Haag and Stephen D. Porter

U.S. GEOLOGICAL SURVEY

Water-Resources Investigations Report 94-4227

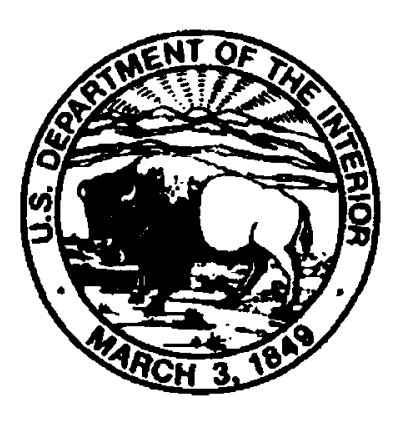

Louisville, Kentucky 


\section{U.S. DEPARTMENT OF THE INTERIOR \\ BRUCE BABBITT, Secretary}

U.S. GEOLOGICAL SURVEY

Gordon P. Eaton, Director

For additional information write to:

District Chief

U.S. Geological Survey

District Office

2301 Bradley Avenue

Louisville, KY 40217
Copies of this report can be purchased from:

U.S. Geological Survey

Earth Science Information Center

Open-File Reports Section

Box 25286, MS 517

Denver Federal Center

Denver, CO 80225 


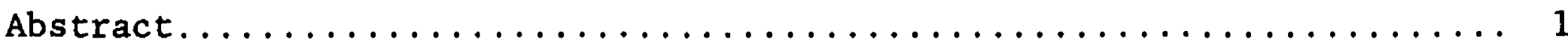

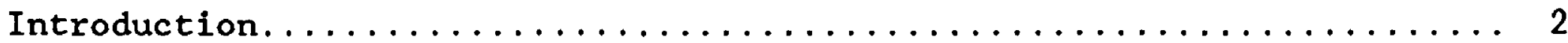

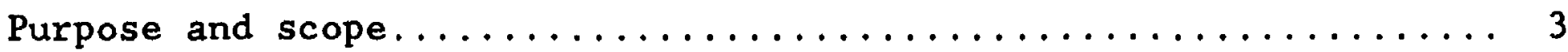

Surface-water-quality issues in the Kentucky River Basin........ 4

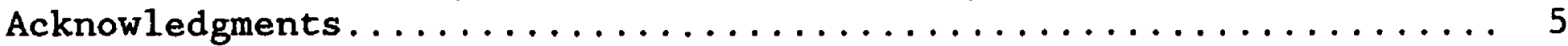

Description of the Kentucky River Basin................... 5

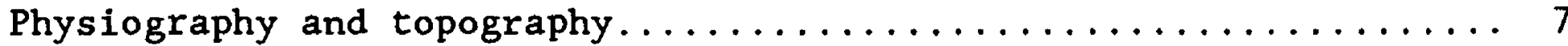

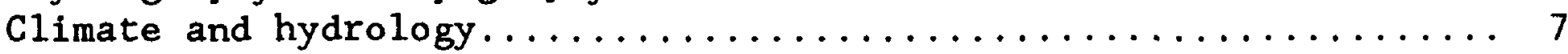

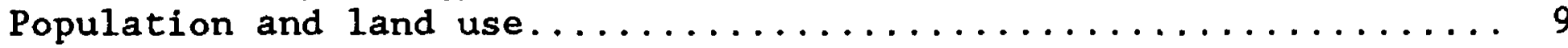

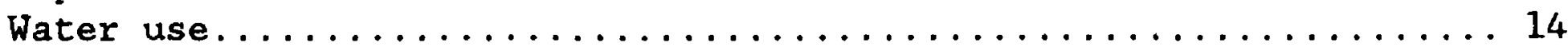

Constituent sources and effects on surface-water quality .......... 14

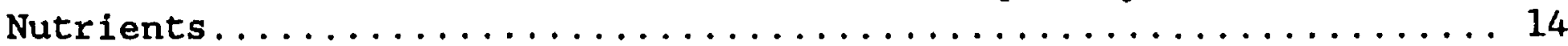

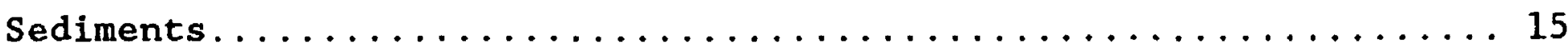

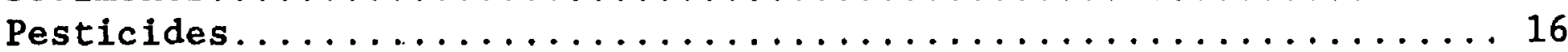

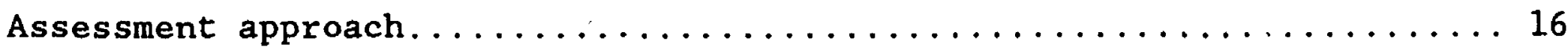

Design of field investigations...................... 17

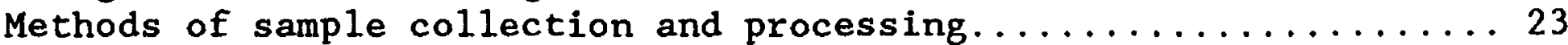

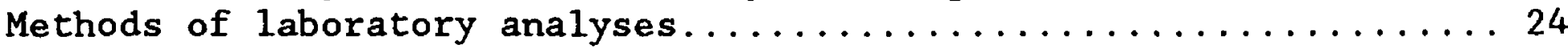

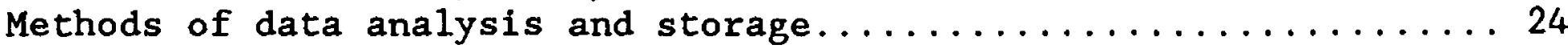

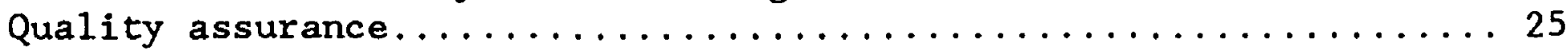

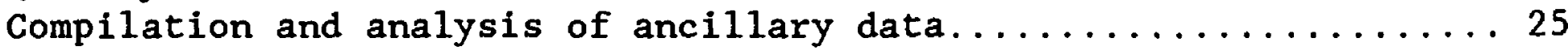

Assessment of nutrients, sediments, and pesticides in streams.......27

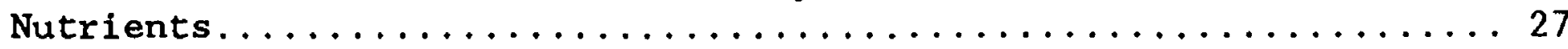

Basin-scale distribution. .......................... 27

Spatial and temporal distribution.............. 28

Estimation of nutrient loads and yields........... 28

Relation of nutrients to discharge, other constituents,

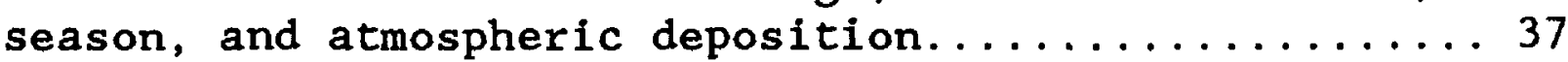

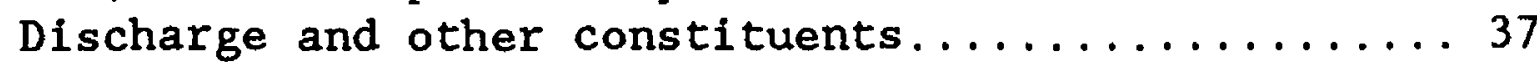

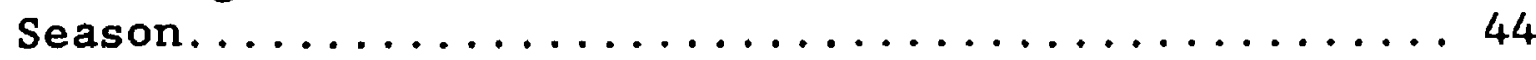

Atmospheric deposition................ 44

Subbasin-scale distribution...................... 45

Relation of nutrients to point-source discharges......445

Relation of nutrients to land use and soils.........662

Relation of nutrients to ground-water sources of constituents........................668

Relation of nutrients to phytoplankton populations in the main stem........................... 72

Relation of nutrients to phytoplankton populations in tributary streams..................... 82

Seasonal nutrient-phytoplankton relations..........884

Temporal trends in nutrient concentrations............ 84

Suspended sediments......................... 88

Spatial and temporal distribution................ 88

Estimation of suspended-sediment loads and yields......... 91

Relation of suspended-sediment concentrations to discharge.... 91

Relation of suspended-sediment concentrations to other

constituents............................ 98 
Relation of suspended-sediment concentrations during low flow to land use and point sources................ 98

Temporal trends in suspended-sediment concentrations........998

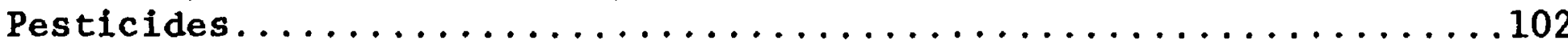

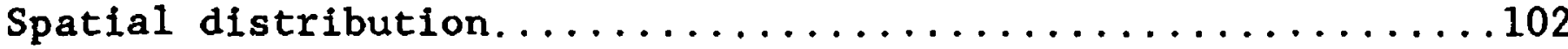

Detection in water samples....................... 102

Accumulation in streambed sediments..............113

Occurrence of pesticides in fish and macroinvertebrate tissue...................................

Relation of pesticides to land uses and other human

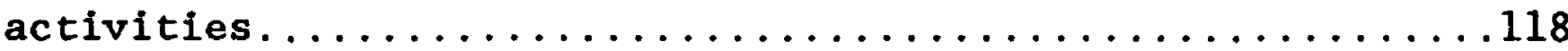

Agricultural land use.........................

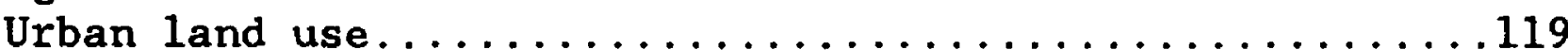

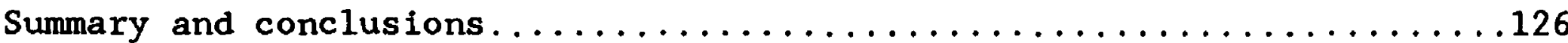

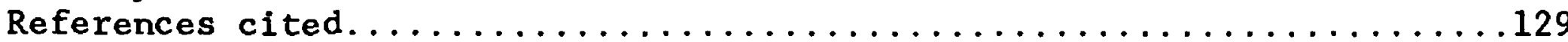

\section{ILLUSTRATIONS}

Figure 1. Map showing Kentucky River Basin................. 6

2. Map showing physiographic regions of the Kentucky River

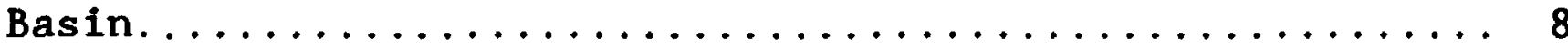

3. Graph of daily mean discharge and instantaneous discharge at time of sampling for the Kentucky River at Lock 2, April 1987 through March 1990................... 10

4. Flow-duration curves of discharge of the Kentucky River

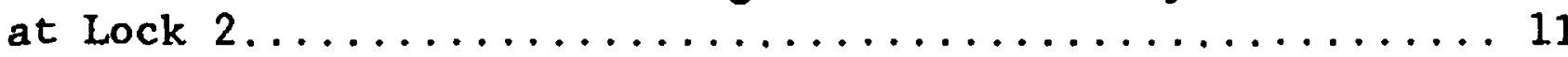

5-8. Maps showing:

5. Population, by county, in the Kentucky River

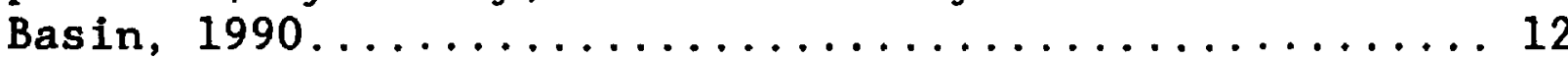

6. Changes in population in counties in the Kentucky River Basin from 1980 to $1990 \ldots \ldots \ldots \ldots \ldots \ldots \ldots \ldots$

7. Location of fixed stations in the Kentucky River Basin............................. 18

8. Location of synoptic sites in the Kentucky River Basin sampled during August 24-28, 1987, and

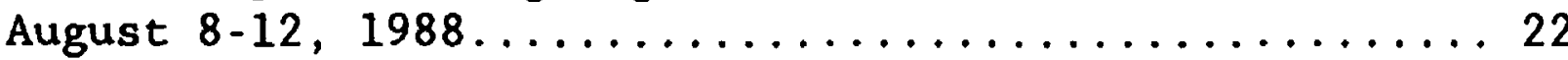

9. Boxplots of annual summary of total phosphorus and total nitrogen concentrations in the Kentucky River at Lock 2 and in Elkhorn Creek at Frankfort, Ky., Apri1 1987-March 1990

10-14. Graphs showing:

10. Variations in mean monthly discharge and mean monthly total phosphorus concentration in the North Fork Kentucky River at Jackson, 1987-90...............39

11. Variations in mean monthly discharge and mean monthly total nitrogen concentration in the Kentucky River at Lock $2,1987-90 \ldots \ldots \ldots \ldots \ldots \ldots \ldots$. . . . . . . . . . . 40 
12. Relation between flow duration and total phosphorus concentration at the fixed stations in the Kentucky River Basin, 1987-90................41

13. Relation between flow duration and nitrate nitrogen concentration at the fixed stations in the Kentucky River Basin, 1987-90..............442

14. Relation between flow duration and total nitrogen concentration at the fixed stations in the Kentucky River Basin, 1987-90..............43

15-27. Maps showing:

15. Instantaneous discharge from wastewater-treatment plants in the Kentucky River Basin, August 1991..... 54

16. Instantaneous loads of ammonia nitrogen from wastewater-treatment plants in the Kentucky River Basin, August 1991.................. 55

17. Concentrations of total phosphorus at synoptic sites in the Kentucky River Basin, August 8-12, $1987 \ldots \ldots .56$

18. Concentrations of total ammonia nitrogen at synoptic sites in the Kentucky River Basin,

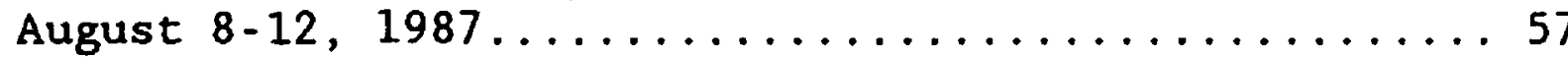

19. Concentrations of dissolved nitrite plus nitrate nitrogen at synoptic sites in the Kentucky River Basin, August $8-12,1987 \ldots \ldots \ldots \ldots \ldots \ldots \ldots \ldots$

20. Percentage of total stream discharge attributable to wastewater-treatment-plant discharge in subbasins of the Kentucky River Basin, August $1987 \ldots \ldots \ldots \ldots 59$

21. Percentage of total nitrogen load attributable to wastewater-treatment-plant discharge in the Kentucky River Basin, August $1987 \ldots \ldots \ldots \ldots \ldots \ldots$

22. Harvested cropland, by county, in the Kentucky River

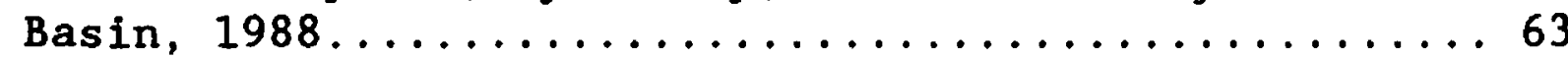

23. Numbers of beef cattle, by county, in the Kentucky River Basin, 1988.......................664

24. Tobacco production, by county, in the Kentucky River

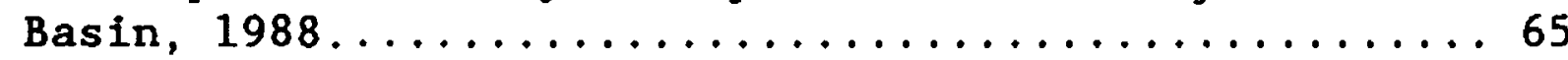

25. Sales of nitrogen fertilizers, by county, in the Kentucky River Basin, 1988................66

26. Sales of phosphorus fertilizers, by county, in the Kentucky River Basin, 1988.............667

27. Characteristic phosphorus content of soils in the Kentucky River Basin....................70

28. Graph of smoothed mean chlorophy11 a and total phosphorus concentrations in the Kentucky River. Data points are means of values for August 1987 and August $1988 \ldots \ldots \ldots \ldots 73$

29. Graph of smoothed mean chlorophyl1 a and nitrite plus nitrate nitrogen concentrations in the Kentucky River. Data points are means of values for August 1987 and August 1988 . 


\section{ILLUSTRATIONS - - Continued}

Page

30. Diagram showing location of major tributarles, navigation locks, and municipal wastewater-treatment plants (WWTP) with respect to the main stem of the Kentucky River.......................... 75

31-35. Graphs showing:

31. Smoothed mean chlorophyll a concentration and mean turbidity in the Kentucky River. Data points are means of values. for August 1987 and August $1988 \ldots \ldots 76$

32. Smoothed mean algal cell density and mean chlorophyll a concentration in the Kentucky River. Data points are means of values for August 1987 and August 1988..778

33. Smoothed mean chlorophyll a concentration and mean percent saturation of dissolved oxygen in the Kentucky River. Data points are means of values

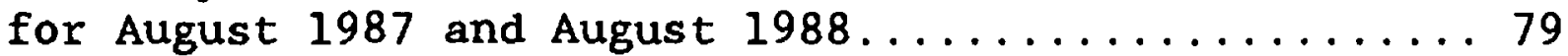

34. Mean chlorophyll a concentration and mean net rate of oxygen production in the Kentucky River. Data points are means of values for August 1987 and

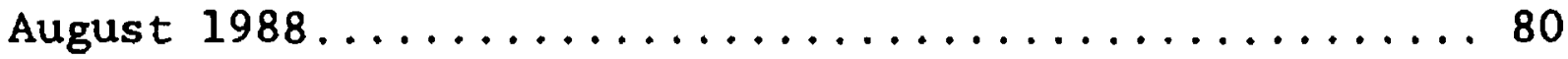

35. Mean chemical oxygen demand in the Kentucky River. Data points are means of values for August 1987

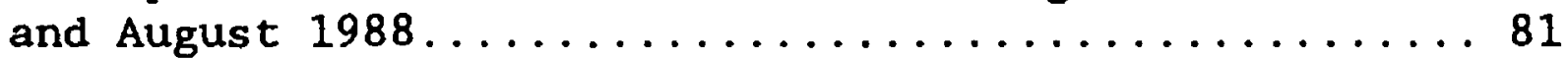

36. Map of chlorophyll a concentration in streams of the Kentucky River Basin, August $1987 \ldots \ldots \ldots \ldots$......... 83

37. Graph showing smoothed mean suspended-sediment concentration

in the Kentucky River, April 1987-March 1990........... 92

38. Boxplots of summary of annual suspended-sediment concentrations in the North Fork Kentucky River at Jackson and in the Kentucky River at Lock 2,

April 1987-March 1990...................... 93

39-42. Graphs showing:

39. Variations in mean monthly suspended-sediment concentrations and discharge in the North Fork Kentucky River at Jackson, April 1987-March 1990..... 95

40. Variations in mean monthly suspended-sediment concentrations and discharge in the Middle Fork

Kentucky River at Tallega, April 1987-March 1990...... 96

41. Variations in mean monthly suspended-sediment concentrations and discharge in the Kentucky River at Lock 2, April 1987-March 1990.

42. Smoothed mean suspended-sediment and mean total phosphorus concentrations in the Kentucky River. Data points are means of values for August 1987

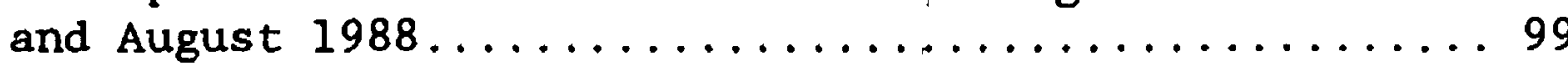

43-53. Maps showing:

43. Instantaneous loads of total suspended solids from wastewater-treatment plants in the Kentucky River Basin, August 1991...........100 
44. Turbidity in streams of the Kentucky River Basin,

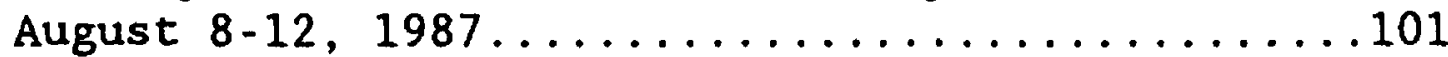

45. Surface-water sampling sites for pesticides in the Kentucky River Basin, 1988-90..........105

46. Streambed-sediment sampling sites for pesticides in the Kentucky River Basin, 1988-90........106

47. Detections of pesticides in surface-water samples in the Kentucky River Basin, 1988-90........111

48. Detections of pesticides in streambed-sediment samples in the Kentucky River Basin, 1988......116

49. Agricultural sales of atrazine, by county, in the

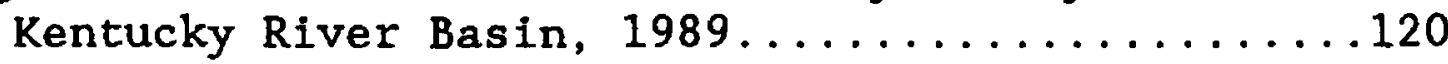

50. Agricultural sales of 2,4-D, by county, in the

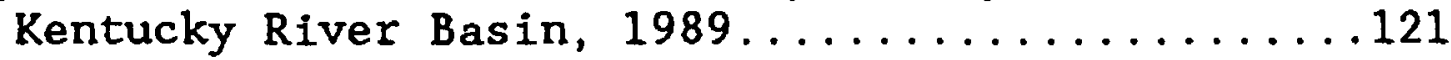

51. Agricultural sales of alachlor, by county, in the Kentucky River Basin, 1989................122

52. Agricultural sales of diazinon, by county, in the Kentucky River Basin, 1989...............123

53. Agricultural sales of malathion, by county, in the Kentucky River Basin, $1989 \ldots \ldots \ldots \ldots \ldots \ldots \ldots \ldots 124$

\section{TABLES}

Tab1e 1. Characterization of the seven fixed stations in the Kentucky River Basin.......................... 19

2. Location of synoptic sites in the Kentucky River Basin................................. 20

3. Statistical summary of nutrient concentrations at selected stations in the Kentucky River Basin................ 29

4. Nutrient-transport summary at selected stations in the Kentucky River Basin........................... 34

5. Water-quality constituents at synoptic sites in the Kentucky River Basin in subbasins unaffected by wastewatertreatment-plant discharges, August 1987 and August 1988.... 46

6. Water-quality constituents at synoptic sites in the Kentucky River Basin and estimated effluent loads of suspended solids and ammonia nitrogen from upstream wastewater-treatment plants.................. 47

7. Annual and seasonal fertilizer sales, by county, in the Kentucky River Basin, July 1986-June 1987............669

8. Average concentrations of nitrite and nitrate in ground water, by county, in the Kentucky River Basin, 1950-87.... 71

9. Trend-test results for nutrients at selected stations in the Kentucky River Basin..................... 85

10. Statistical summary of suspended-sediment concentrations at selected stations in the Kentucky River Basin......... 89

11. Summary of suspended-sediment transport at selected stations in the Kentucky River Basin........................ 94 
12. Incidence of detection of insecticides in water and streambedsediment samples in the Kentucky River Basin, 1988-90.....103

13. Incidence of detection of herbicides in water samples in the Kentucky River Basin, 1988-90..................... 104

14. Concentrations of pesticides detected in water samples from streams in the Kentucky River Basin, 1988-89.......... 107

15. Concentrations of pesticides detected in water samples from streams in the Kentucky River Basin, 1990.............109

16. Maximum concentrations of pesticides detected in streambedsediment samples from streams in the Kentucky River

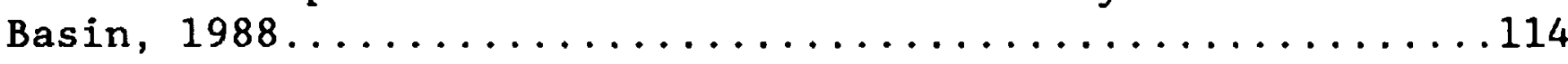

17. Estimated use of selected herbicides and insecticides by lawn-care companies in counties of the Kentucky River

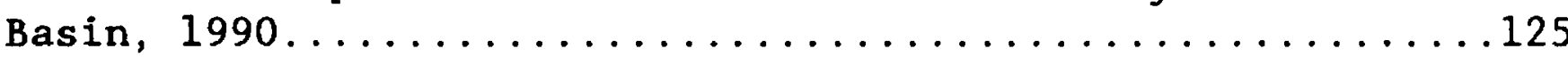

\section{CONVERSION FACTORS AND ABBREVIATIONS}

\section{Multiply}

inch (in.)

foot $(\mathrm{ft})$

mile (mi)

square mile $\left(\mathrm{mi}^{2}\right)$

ounce, fluid (oz)

foot per second ( $f t / s)$

cubic foot per second $\left(\mathrm{ft}^{3} / \mathrm{s}\right)$

million gallons per day (Mgal/d)
By

25.4

0.3048

1.609

2.590

0.02957

0.3048

0.02832

0.04381
To obtain

millimeter

meter

kilometer

square kilometer

1iter

meter per second

cubic meter per second

cubic meter per second

Temperature in degrees Fahrenheit $\left({ }^{\circ} \mathrm{F}\right)$ can be converted to degrees Celsius $\left({ }^{\circ} \mathrm{C}\right)$ as follows:

$$
{ }^{\circ} \mathrm{C}=\left({ }^{\circ} \mathrm{F}-32\right) / 1.8
$$

Abbreviated water-quality units used in this report: Various measurements associated with water quality are given in metric units. Sample volumes are given in liters (L) and milliliters (mL). Descriptions of some sampling equipment are given in millimeters (mm), and pore sizes of filters are given in micrometers $(\mu \mathrm{m})$. Chemical concentrations are given in milligrams per liter $(\mathrm{mg} / \mathrm{L})$, micrograms per liter $(\mu \mathrm{g} / \mathrm{L})$, milligrams per kilogram $(\mathrm{mg} / \mathrm{kg})$, or micrograms per kilogram $(\mu \mathrm{g} / \mathrm{kg})$. Milligrams per liter is a unit expressing the concentration of chemical constituents in solution as weight (milligrams) of solute per unit volume (liter) of water. One thousand micrograms per liter is equivalent to one milligram per liter. For concentrations less than $7,000 \mathrm{mg} / \mathrm{L}$, the numerical value is the same for concentrations in parts per million (ppm). 
Total analyses of constituent concentrations in the suspended-sediment fraction are reported either as a ratio of constituent weight in micrograms $(\mu g)$ to sediment weight in grams ( $g$ ) or as a percentage by weight. Sediment fraction surface area is reported as square meters $\left(\mathrm{m}^{2}\right)$ per gram ( $\mathrm{g}$ ) of sediment.

Water year: The 12 -month period from October 1 through September 30 . The water year is designated by the calender year in which it ends.

Standard abbreviations used in station names:

$\begin{array}{llllll}\text { Cr } & \text { Creek } & \text { M } & \text { Middle } & \text { R } & \text { River } \\ \text { Fk } & \text { Fork } & \text { N } & \text { North } & \text { S } & \text { South } \\ \text { Ky } & \text { Kentucky } & \text { nr } & \text { near } & & \end{array}$


WATER-QUALITY ASSESSMENT OF THE KENTUCKY RIVER BASIN, KENTUCKY: NUTRIENTS, SEDIMENTS, AND PESTICIDES IN STREAMS, 1987-90

By Kim H. Haag and Stephen D. Porter

\begin{abstract}
Data were collected to describe the spatial and temporal variability of nutrients, suspended sediment, and pesticides in the Kentucky River Basin, Kentucky, from April 1987 through March 1990. Nutrient and suspended-sediment samples were collected monthly at seven fixed stations in the 7,000-squaremile basin. Synoptic studies of nutrients and suspended sediments included water-sample collection at a total of 74 sites in both August 1987 and August 1988. The distribution of pesticides was studied by collecting samples at a limited number of fixed stations and synoptic sites during the 3-year period. Efforts were made to identify the causative factors affecting instream concentrations and loads of target constituents.
\end{abstract}

Nutrient concentrations did not vary significantly from year to year at the fixed stations. Although no statistically significant correlations were found between concentrations of nutrients and discharge, high concentrations of phosphorus were found at high discharges in nonurban areas, and high concentrations of total nitrogen were found at the upper and lower extremes of discharge near the mouth of the Kentucky River. Significant correlations were found between concentrations of total phosphorus and suspended sediment. At many sampling sites in urban areas, most of the stream nitrogen load was primarily attributable to wastewater-treatment-plant (WWTP) effluent, even where only a small proportion of the total stream discharge was attributable to WWTP effluent. At synoptic sites downstream from WWTP's, instream nitrogen concentrations were among the highest measured in the Kentucky River Basin.

No significant correlations were found among 1 and-use types and concentrations of nitrogen at the fixed sites. Concentrations of phosphorus were positively correlated with urban and agricultural land use but negatively correlated with forest and mining land use. The high phosphorus content of Bluegrass Region soils was an important source of phosphorus in streams draining that area. Correlations between forms of phosphorus and nitrogen and land-use type were similar at synoptic sites but were not significant statistically.

Phytoplankton chlorophyl1 a concentrations in the Kentucky River main stem were positively correlated with concentrations of total phosphorus and total ammonia plus organic nitrogen during low flows. The positive correlation of chlorophyll a with total ammonia plus organic nitrogen indicates that a considerable proportion of total nitrogen was transported as algal biomass during periods of low discharge. The highest algal-cell densities and the highest concentrations of chlorophyll a were found in the lower Kentucky River, downstream from river mile 180. In tributary streams, phytoplankton chlorophyll a concentrations were also positively correlated with concentrations of total phosphorus and total ammonia plus organic nitrogen. In August 1987 and August 1988, several streams receiving urban sources of nutrients contained low concentrations of phytoplankton 
chlorophyll a, but demonstrated high levels of algal productivity, an indication that periphyton probably dominated the algal community in those streams. Streams affected by agricultural sources of nutrients contained higher densities of phytoplankton than streams that drained forested areas. Median chlorophyl1 a concentrations and algal cell densities were substantially lower in streams that drained surface-mined areas than in streams that drained agricultural and urban areas.

The median concentration of suspended sediment was lowest in Elkhorn Creek at Frankfort and highest in the North Fork of the Kentucky River, where mining is a principal land use. The trend in suspended-sediment

concentrations during the 3-year study period was a downstream decrease in the Kentucky River main siem from the headwaters to the mouth during the 3-year study period. Mean suspended-sediment concentrations for the study period were correlated with discharge at the fixed sites; concentrations were always lower in summer, typically a low-flow period. No significant correlations were found among suspended-sediment concentrations and any of the nutrient forms studied in the Kentucky River Basin, with the exception of phosphorus. No correlations were found between land use and total suspended-sediment concentrations, but the level of resolution of land-use data may not have been adequate to reflect differences at the subbasin scale. A significant 15-yearlong downward flow-adjusted trend in suspended-sediment concentrations was indicated at a site near the mouth of the Kentucky River.

Atrazine was found in water samples throughout the Kentucky River Basin. Other herbicides frequently found were 2,4-D, alachlor, metoalchlor, and dicamba. Diazinon, malathion, and parathion were the most frequently detected organophosphate insecticides in water samples, particularly in the Elkhorn Creek Basin. Analyses of streambed-sediment samples resulted in frequent detections of several organochlorine insecticides, including aldrin, chlordane, DDT, DDE, dieldrin, endrin, endosulfan, heptachlor, heptachlor epoxide, and 1indane. Many of the pesticides detected in the Kentucky River Basin were in counties of the Bluegrass Region, where agricultural land use is dominant. Residential pesticide application in urban areas in several counties in the Bluegrass Region might also affect the presence of pesticides in surface streams.

\section{INTRODUCTION}

Elevated concentrations of nutrients, suspended sediments, and pesticides cause many problems in surface-water systems at local, regional, and national scales. Issues associated with these three classes of water-quality constituents are related to one another in many respects. These classes of constituents commonly have urban and rural point and nonpoint sources in common, they interact in various ways depending on ambient surface-water conditions, and they directly and indirectly affect the biotic community in streams. Although nutrients, sediments, and pesticides also affect other water-quality characteristics individually and collectively, the importance of these interactions warrants their treatment together in a single report.

Nutrients and suspended sediments are among the most well studied of the numerous characteristics used to assess water quality. As used in this 
report, the term "nutrients" refers to that group of constituents that are essential for plant growth, including various forms of nitrogen and phosphorus. Surface waters differ in background concentrations of nutrients and suspended sediments as a function of basin geology, geomorphology, and geochemistry. Basin topography, soil type, and land cover also dictate, in large measure, the erosional capacity of drainage areas and, consequently, the amount and size of suspended sediments in receiving streams in the basin. The input of nutrients and suspended sediments to surface waters is increased by human activities associated primarily with agriculture, wastewater treatment, industrial effluent, urban runoff, coal mining and oil production, and construction. Furthermore, interactions among suspended sediments and nutrients are significant because of the ability of sediment particles to adsorb some nutrient forms.

Much less well studied are the various pesticides that reach surface waters in runoff largely from cropland, pastureland, and residential property. In addition, knowledge of the fate and transport of herbicides and insecticides and their effects on the biological communities in aquatic systems is incomplete. The ability of sediment particles to adsorb and transport organic compounds increases the distribution of pesticides and may affect their concentration in surface waters.

The U.S. Geological Survey (USGS), as part of the USGS National WaterQuality Assessment (NAWQA) program, has studied the streams in the Kentucky River Basin to assess surface-water quality. Data were collected for assessments of the sources, occurrence, distribution, and fate of nutrients, sediments, and pesticides in the basin. The information generated in these studies is available to water managers, policymakers, and the public to improve the effectiveness of water-quality management and the assessment of proposed changes in land- and water-management practices.

\section{Purpose and Scope}

This report presents results of the Kentucky River Basin pilot NAWQA project. The report includes descriptions of (1) the distributions and trends in concentrations of selected nutrients, sediments, and pesticides in streams, (2) the distributions and trends of these constituents to natural physical and chemical processes as well as human factors that affect water quality, and

(3) the possible interactions of these constituents and potential effects of observed water-quality on aquatic biota.

The temporal and spatial distribution of nutrients, sediments, and pesticides was evaluated by use of several sources of data. Water and suspended-sediment samples were collected monthly at seven fixed stations during April 1987-March 1990. Water and sediment samples were also collected during low-flow synoptic (spatial distribution) surveys at 74 stations in August 1987 and 74 stations in August 1988. Water-quality data collected by the Kentucky Natural Resources and Environmental Protection Cabinet, Division of Water (KDOW) during 1986-89 at 11 fixed stations in the Kentucky River Basin ( 4 of which were also being monitored by the USGS) were analyzed in conjunction with NAWQA data to enhance the understanding of the spatial distribution of constituent concentrations, loads, and trends. 


\section{Surface-Water-Quality Issues in the Kentucky River Basin}

The following brief overview of the historical data on water-quality conditions in the Kentucky River Basin provides a context for the discussion of relevant issues related to nutrients, sediments, and pesticides.

Concentrations of total phosphorus ranged from 10 to $3,700 \mu \mathrm{g} / \mathrm{L}$ in 251 water samples collected in the basin during 1951-86 (Smoot and others, 1991). Highest total phosphorus concentrations were found in streams receiving sewage effluent. High total phosphorus concentrations were also found throughout the Bluegrass Region, which is underlain by phosphatic limestone (Smoot and others, 1991). Spatially, total phosphorus concentrations increase steadily from the headwater reaches to the river mouth; temporally, however, no trends are evident from the available data.

The high phosphorus content of soils in the Inner Bluegrass Region (>150 ppm) promotes growth of nitrogen-fixing plant species, which are responsible for relatively high ambient nitrogen concentrations. The few data available for the period 1979-86 indicate a slightly upward trend in total nitrogen concentrations from the headwaters to the mouth of the river.

In the Kentucky River Basin, suspended-sediment concentrations ranged from less than 1.0 to $18,000 \mathrm{mg} / \mathrm{L}$ in surface-water samples collected during 1979-86 (Smoot and others, 1991). More than 90 percent of the suspended sediment in the basin is silt and clay (Flint, 1983). The basin includes about $1,070 \mathrm{mi}^{2}$ of disturbed land and $1,700 \mathrm{mi}$ of eroding streambanks and roadbanks that contribute to stream-sediment loads. Such nonpoint-source runoff has noticeably degraded about 40 percent of the streams in the basin (Kentucky Environmental Quality Commission, 1992). Decreases in suspended. sediment concentrations were found at 7 of 11 sites during 1976-86 (Smoot and others, 1991). These decreases may reflect the recent adoption of no-till practices for tobacco, corn, and soybeans, which are the major crops in the basin. Stream reaches draining areas disturbed by mining and the associated deforestation exhibited higher suspended-sediment concentrations than streams in areas devoted to pasture and row-crop agriculture.

Herbicide and insecticide use has increased in recent years in the Kentucky River Basin (Gianessi, 1986). Only one analysis of a water sample for herbicides was identified in the compiled data base for 1976-86. Of the three target analytes in that sample, 2,4,5-T and 2,4-D were detected but silvex was not. In the Kentucky River Basin, atrazine and butylate together account for more than half of all herbicide used (Smoot and others, 1991); however, analyses for these and other common herbicides are not available. Organochlorine insecticides, including benzene hexachloride, chlordane, lindane, dieldrin, P,P-DDD, and P,P-DDE, were detected in numerous samples of stream sediment and fish tissue during 1976-86 (Smoot and others, 1991). Analyses for organophosphorus insecticides were limited to two samples, in which no detectable concentrations were found.

Many streams in the basin continue to support a large and diverse aquatic faunal community. These include reaches of Eagle Creek and E1khorn Creek; parts of the Dix River system; Red River; and reaches of the Middle and South Forks of the Kentucky River. Extensive data are available on the abundance 
and distribution of aquatic biota in the Kentucky River Basin. Bradfield and Porter (1990) reviewed and summarized much of this information, including biological data collected by Federal, State, and private institutions. Surface-water quality is generally suitable to support designated uses, according to Federal and State water-quality criteria (Kentucky Natural Resources and Environmental Protection Cabinet, 1992). The 1986 report to Congress for Kentucky (Kentucky Natural Resources and Environmental Protection Cabinet, 1986) assessed water-quality conditions for approximately 900 of the 3,450 river miles in the Kentucky River Basin and found that only 6 percent of the river miles assessed were significantly contaminated (White and others, 1987). However, expected increases in population and industrial growth will increase water use, and several municipal dischargers will require additional treatment facilities to prevent water-quality violations (Kentucky Environmental Quality Commission, 1992). Moreover, continued agricultural development could potentially increase inputs of nutrients, sediments, and pesticides. Accelerated eutrophication of surface waters from nutrient inputs from municipal point sources and agricultural nonpoint sources is possible. The effects of these changing conditions on aquatic life are not yet determined.

\section{Acknowledgments}

The NAWQA project liaison committee for the Kentucky River Basin provided continued guidance and input to this project. Members of the committee included representatives from the U.S. Fish and Wildlife Services; Kentucky Department of Agriculture; Kentucky Natural Resources and Environmental Protection Cabinet; Kentucky Department of Fish and Wildlife Resources; Kentucky Geological Survey; and Kentucky Water Resources Research Institute.

Many people and organizations assisted in the preparation of this report. The authors are especially grateful to Ernest Collins of the Kentucky Division of Pesticides, Vicki Ray of the Kentucky Natural Resources and Environmental Protection Cabinet, and Corine Wells of the Kentucky Division of Water.

\section{DESCRIPTION OF THE KENTUCKY RIVER BASIN}

The Kentucky River Basin, located in east-central Kentucky, has a drainage area of about $7,000 \mathrm{mi}^{2}$ and includes about $3,500 \mathrm{mi}$ of streams (Smoot and others, 1991). The main stem of the Kentucky River originates in southeastern Kentucky and flows northwestward approximately $405 \mathrm{mi}$ to its confluence with the Ohio River at Carrollton (fig. 1). Major tributaries include the North, Middle, and South Forks Kentucky River; Red River; Dix River; Elkhorn Creek; and Eagle Creek. The Kentucky River drains all or parts of 39 counties in the state and serves as a source of drinking water for 95 percent of the basin population. 


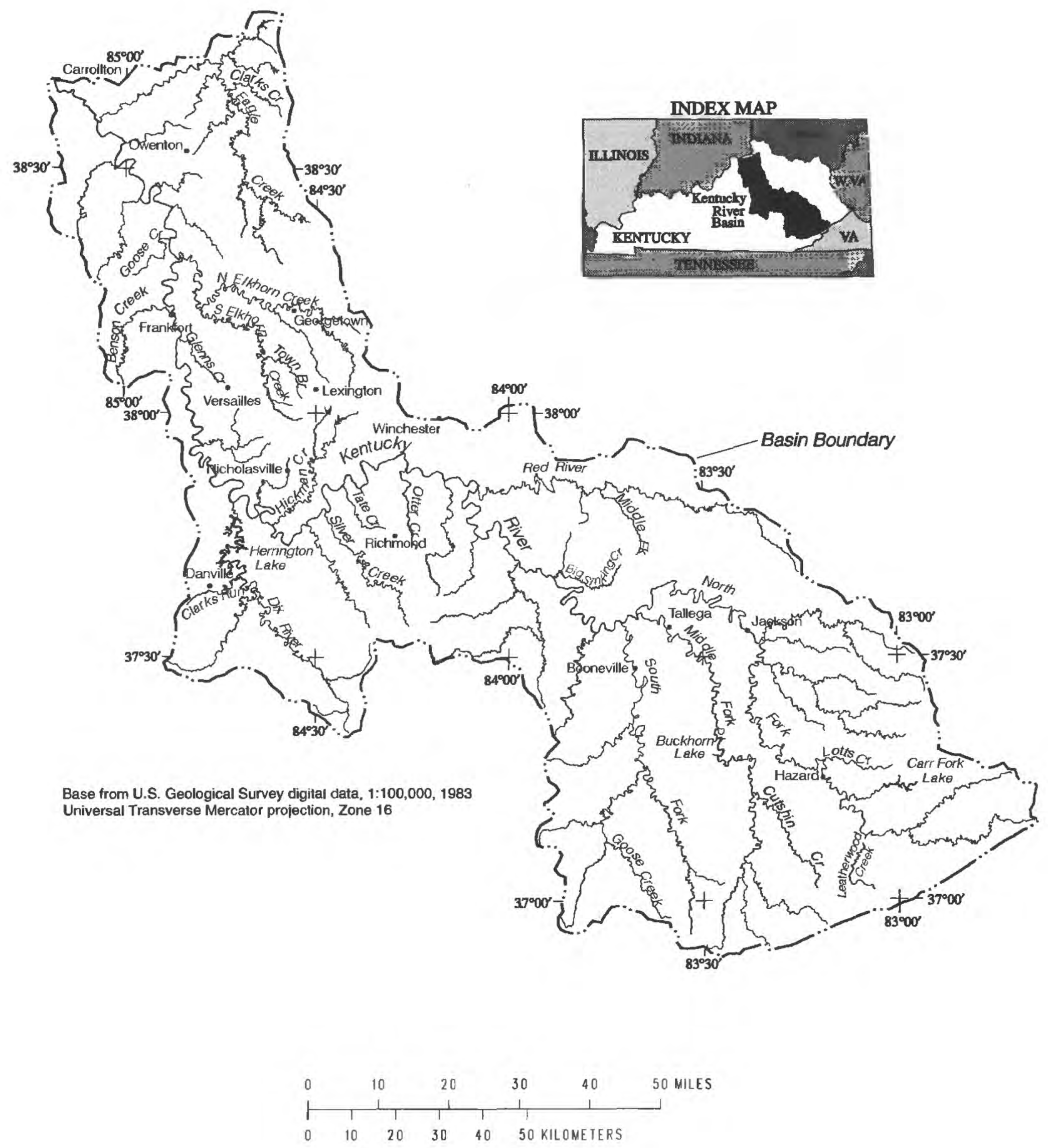

Figure 1. Kentucky River Basin. 


\section{Physiography and Topography}

Detailed descriptions of the physiography, geology, and land-use patterns in the Kentucky River Basin are given by Smoot and others (1991) and S.D. Porter (U.S. Geological Survey, written commun., 1993). The basin consists of four physiographic regions: the Eastern Kentucky Coal Field, the Knobs, the Inner Bluegrass, and the Outer Bluegrass (fig. 2). Surface-water characteristics, 1and-use patterns, and population distribution differ among the regions. These variations are discussed with respect to their effects on water quality.

The southern part of the basin lies within the Eastern Coal Field Region. Elevations range from 1,000 to $3,200 \mathrm{ft}$ above sea level, and terrain consists of narrow valleys and narrow, steep-sided ridges. Soils, which are moderately deep and generally well drained, are formed from siltstones, sandstones, and shales. Approximately 98,000 acres of land have been directly affected by coal-mining activities.

The Knobs Region, characterized by its distinctive conical and flattopped hills, separates the Eastern Coal Fields Region from the Bluegrass Region in Kentucky. Broad valleys underlain by shale separate the sandy limestone and sandstone caprock of the hills. Elevations range from 600 to more than 1,600 ft above sea level. Soils are shallow and clayey and are poorly drained because of a dense subsurface layer of compacted silt overlying shale (U.S. Department of Agriculture, 1981).

The Inner Bluegrass Region is in the north-central part of the basin and is characterized by gently rolling upland underlain by thick-bedded phosphatic limestone. Elevations range from 800 to $1,000 \mathrm{ft}$ above sea level. Considerable surface and subsurface solution of bedrock has resulted in extensive karst topography in this region. Soils developed from the phosphatic limestone are moderately deep, are fairly well drained and consist of silty loam over a clayey subsoil.

The remaining, northern part of the basin lies within the Outer Bluegrass Region. Elevations range from 800 to $1,000 \mathrm{ft}$ above sea level, and areas near streams are dissected and rugged. The Outer Bluegrass Region is underlain by thin-bedded limestone interbedded with considerable shale. Some surface and subsurface solution has resulted in small sinkholes and subdued karst topography. Soils are moderately deep, fairly well drained, and generally suitable for farming.

\section{Climate and Hydrology}

The climate and hydrology of the Kentucky River Basin are described in detail by Smoot and others (1991). In brief, the climate is temperate and humid. Mean annual temperature is $56^{\circ} \mathrm{F}\left(13^{\circ} \mathrm{C}\right)$; daily mean temperatures vary from $25^{\circ} \mathrm{F}\left(-4^{\circ} \mathrm{C}\right)$ in January and February to $87^{\circ} \mathrm{F}\left(31^{\circ} \mathrm{C}\right)$ in July and August (U.S. Department of Agriculture, 1981). Annual precipitation averages 46 in. and ranges from $40 \mathrm{in.}$ in the northern part of the basin to $48 \mathrm{in.}$ in the 


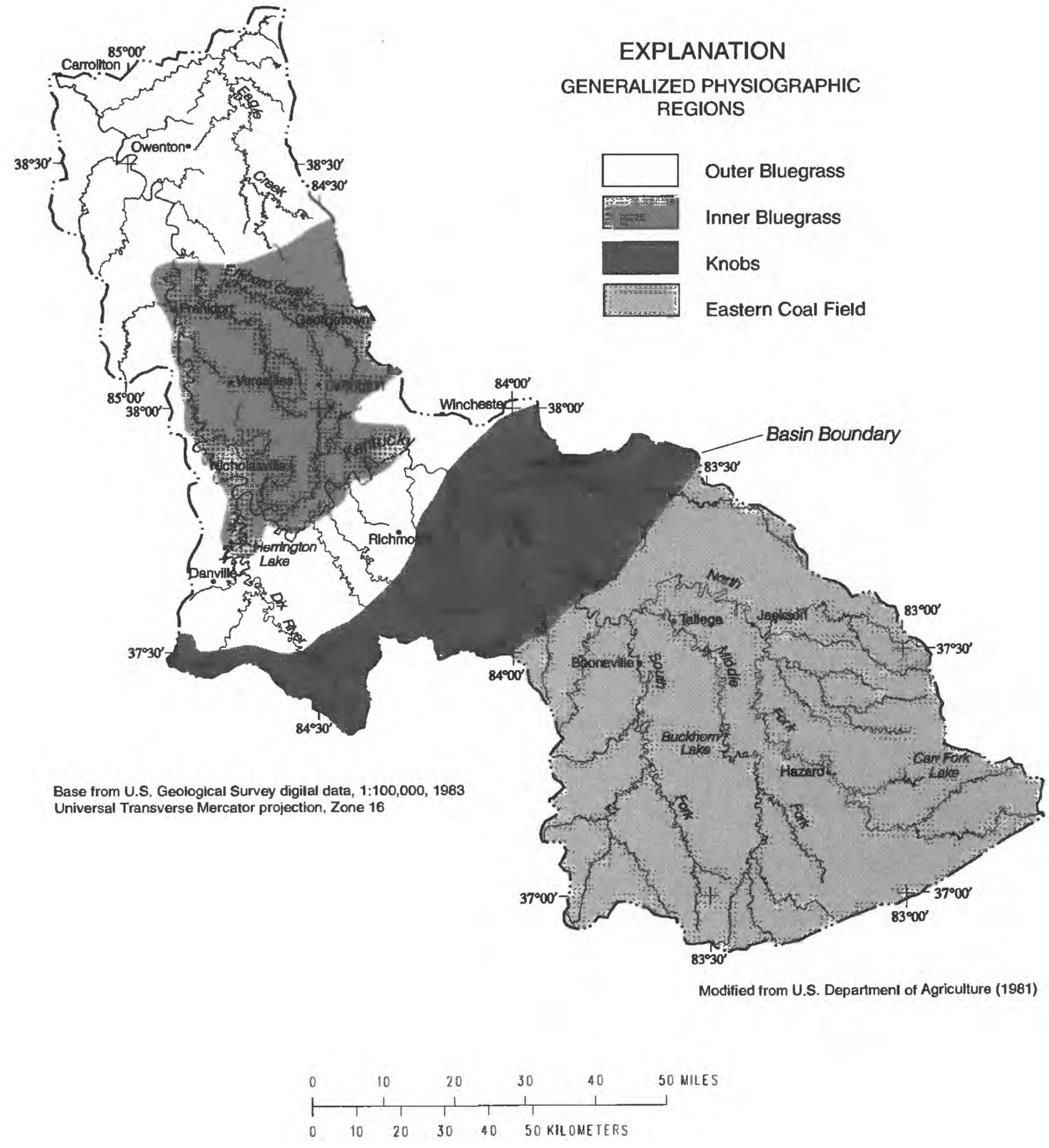

Figure 2. Physiographic regions of the Kentucky River Basin. 
southern part (Elam and others, 1972). Mean annual precipitation at Lexington during 1975-90 was $44.4 \mathrm{in.} \mathrm{March} \mathrm{is} \mathrm{typically} \mathrm{the} \mathrm{wettest} \mathrm{month,} \mathrm{and} \mathrm{October}$ is the driest.

Runoff and ground-water recharge in the basin vary temporally and spatially (Smoot and others, 1991). Basinwide, 28 percent of the annual precipitation results in surface runoff, and 9 percent enters the ground. Runoff is greater in the mountains of the Eastern Coal Field Region than in the Inner and Outer Bluegrass Regions. Within the Bluegrass Region, considerable rainfall enters the ground water directly through sinkholes.

Streamflow varies throughout the basin, in response to differences in geology, topography, and land use. Streams flowing across the highly permeable karst terrain of the Bluegrass regions commonly consist of dry and flowing reaches, depending on the extent of karst development. The average annual unit flow of streams in the study area is $1.4\left(\mathrm{ft}^{3} / \mathrm{s}\right) / \mathrm{mi}^{2}$. During hydrologic extremes, however, unit flows differ substantially. Unit peak flow in the basin ranged from $344\left(\mathrm{ft}^{3} / \mathrm{s}\right) / \mathrm{mi}^{2}$ at Cutshin Creek at Wooton to $18.3\left(\mathrm{ft}^{3} / \mathrm{s}\right) / \mathrm{mi}^{2}$ in the Kentucky River at Lock 2. The 7-day 10-year low-flow discharges for 1976-86 ranged from zero in the Dix River to $3.7 \mathrm{ft}^{3} / \mathrm{s}$ in the Red River. A hydrograph of daily mean discharge and instantaneous discharge at the time of water-quality sampling during April 1987-March 1990 (Toms and others, 1988; Garcia and others 1989, 1990) at Lock 2 on the Kentucky River is shown in figure 3. The flow-duration curve at Lock 2 (fig. 4) shows the percentage of time that a given discharge was equaled or exceeded at this downstream site at the time of sampling, during the period of the NAWQA sampling, and during the period of record. With the exception of extremely low flows, sampling at the fixed stations during this study covered the entire range of the flow duration.

The flow of the Kentucky River main stem is regulated by 14 lock and dam structures that maintain at least $6 \mathrm{ft}$ of water for navigation from a point just downstream of the confluence of the North, Middle, and South Forks to the mouth. The Kentucky River Basin has no natural lakes. A total of 15 reservoirs in the basin have a combined volume of 286,000 acre-ft and a combined surface area of 6,530 acres (Miller and others, 1975). Three major reservoirs--Herrington, Buckhorn, and Carr Fork (fig. 1)--make up 75 percent of total reservoir surface area and 90 percent of total reservoir volume. The operation of reservoirs for flood control and low-flow augmentation has resulted in moderation of postimpoundment flow extremes, typified by comparatively low high-flow periods and comparatively high low-flow periods (fig. 5).

\section{Population and Land Use}

Population in the Kentucky River Basin was estimated at 64y,260 in 1990 (Decker, 1991) and is concentrated in a few counties (fig. 5). Population in the basin increased slightly (2.7 percent) from 1980 to 1990 . Fourteen counties increased in population (fig. 6), whereas at least 10 counties lost population during that interval. The largest increases were in counties surrounding the Lexington metropolitan area, and the greatest losses were in the Eastern Coal Field Region. 


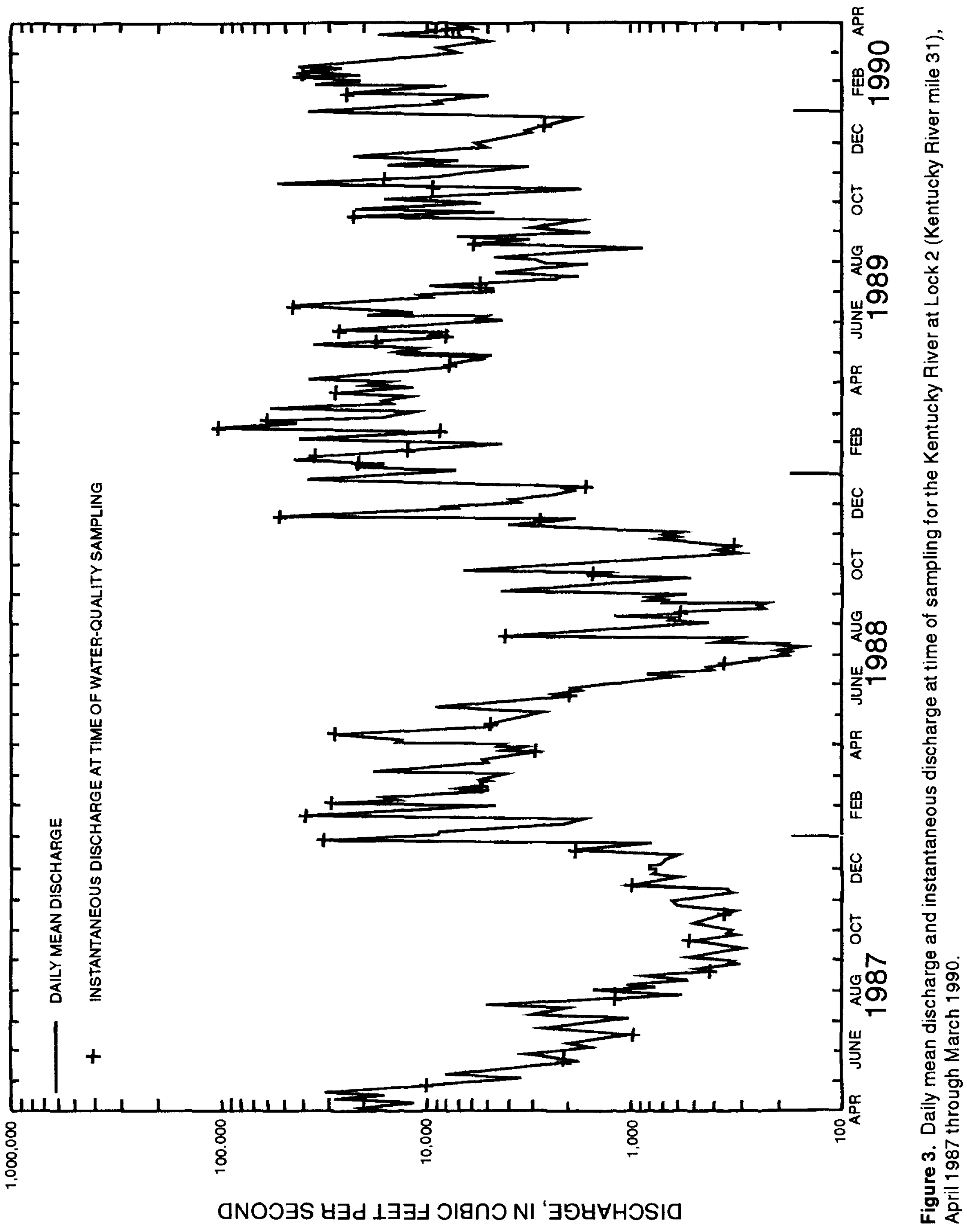




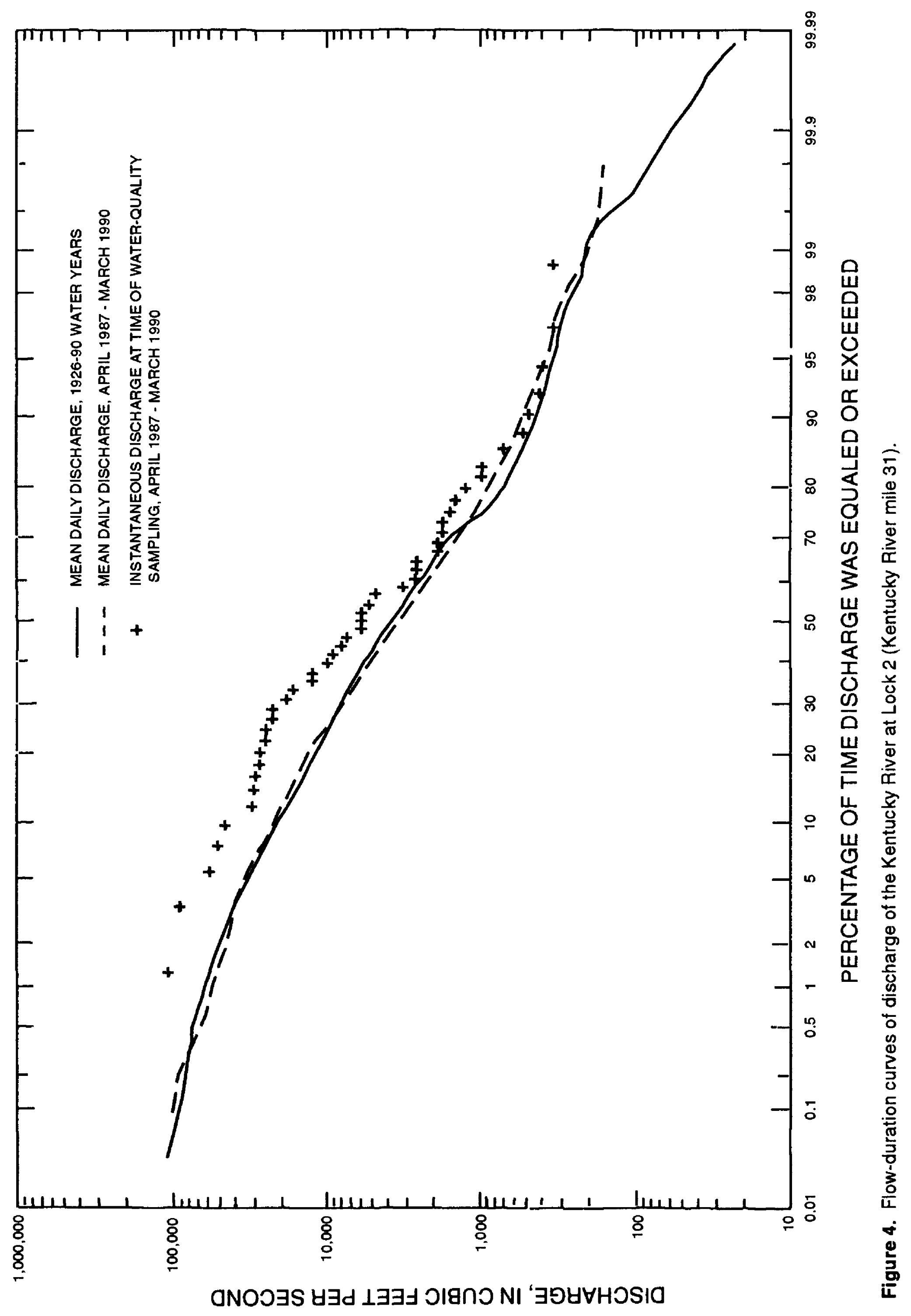




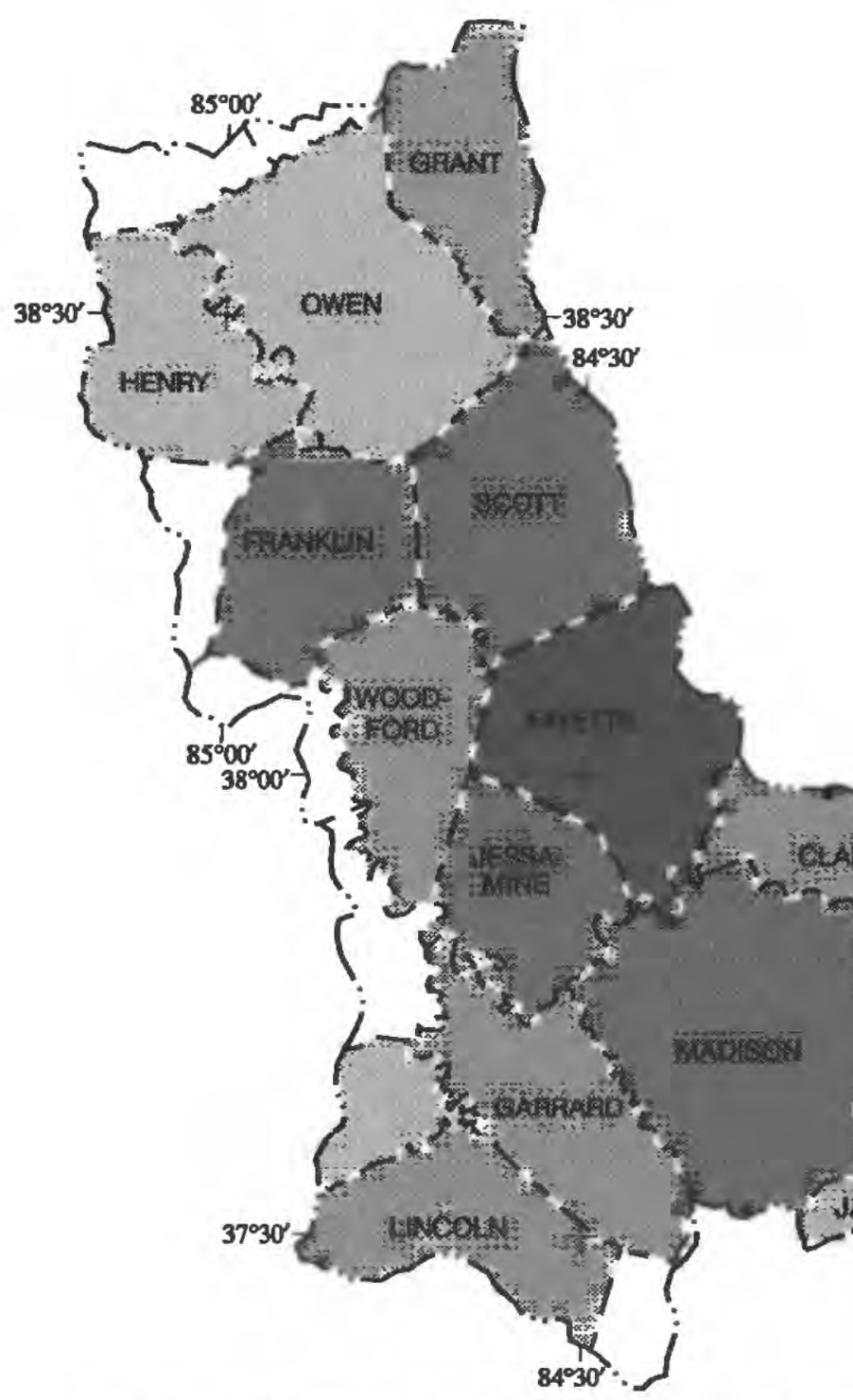

Base from U.S. Geological Survey digital data, 1:100,000, 1983 Universal Transverse Mercator projection, Zone 16

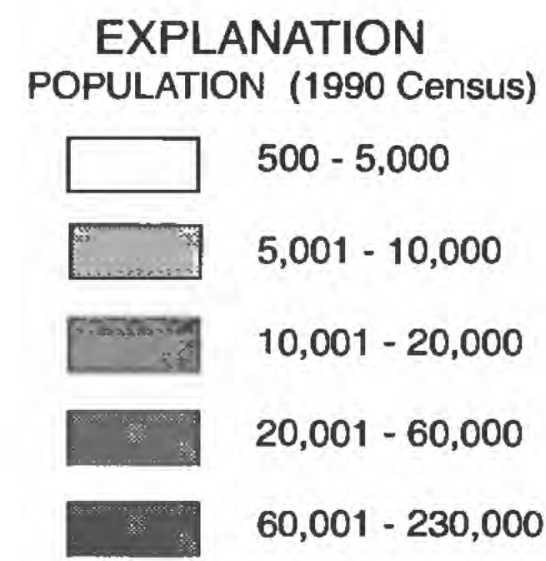

$84^{\circ} 00^{\circ}$

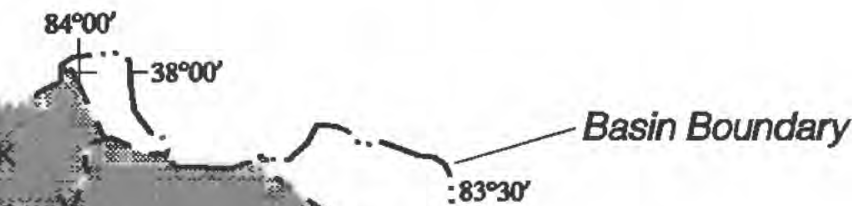

woure

Esmet:
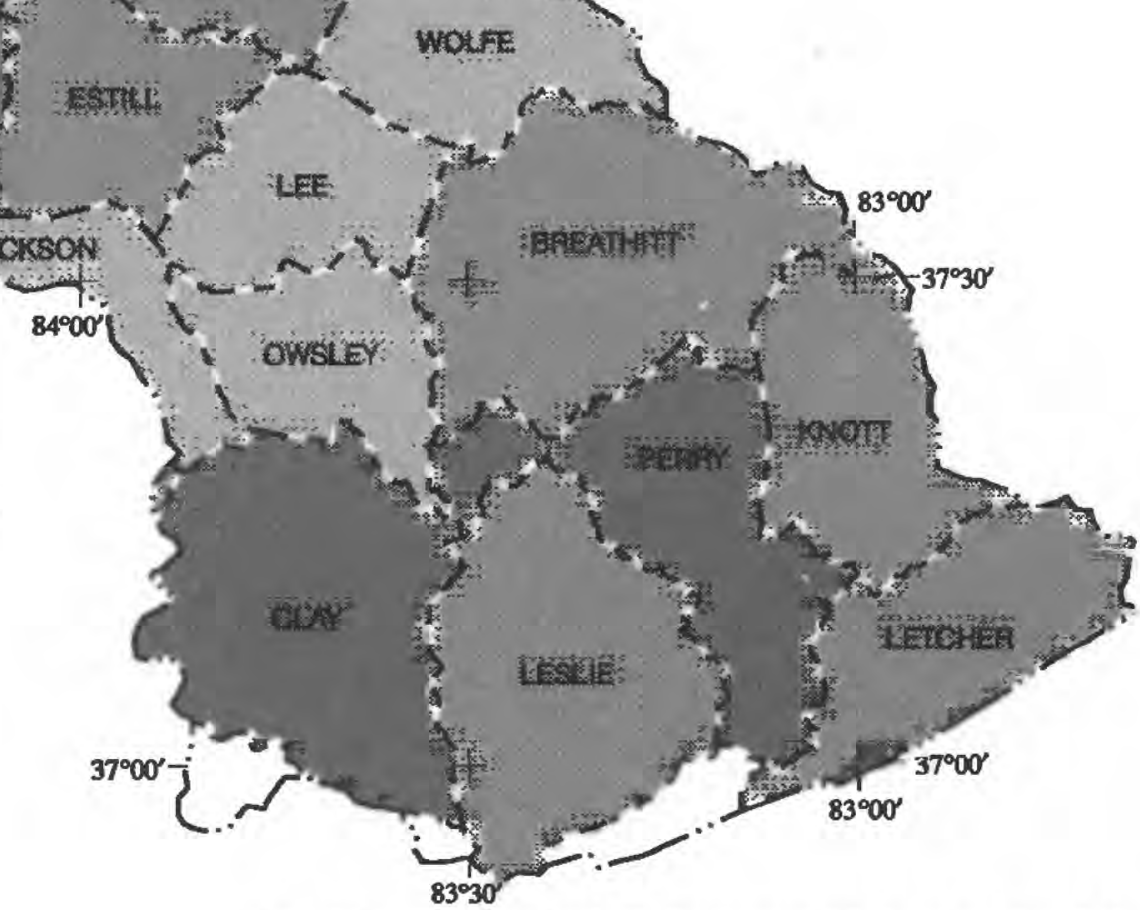

Population data from Kentucky Economic Statistics, Department of Existing Business and Industry, Division of Research and
Planning, 1991

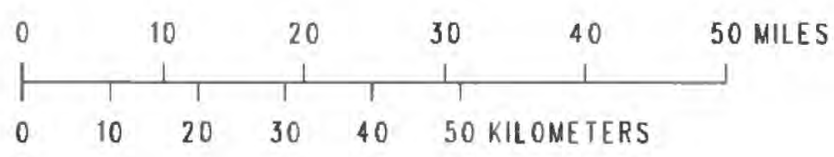

Figure 5. Population, by county, in the Kentucky River Basin, 1990. 


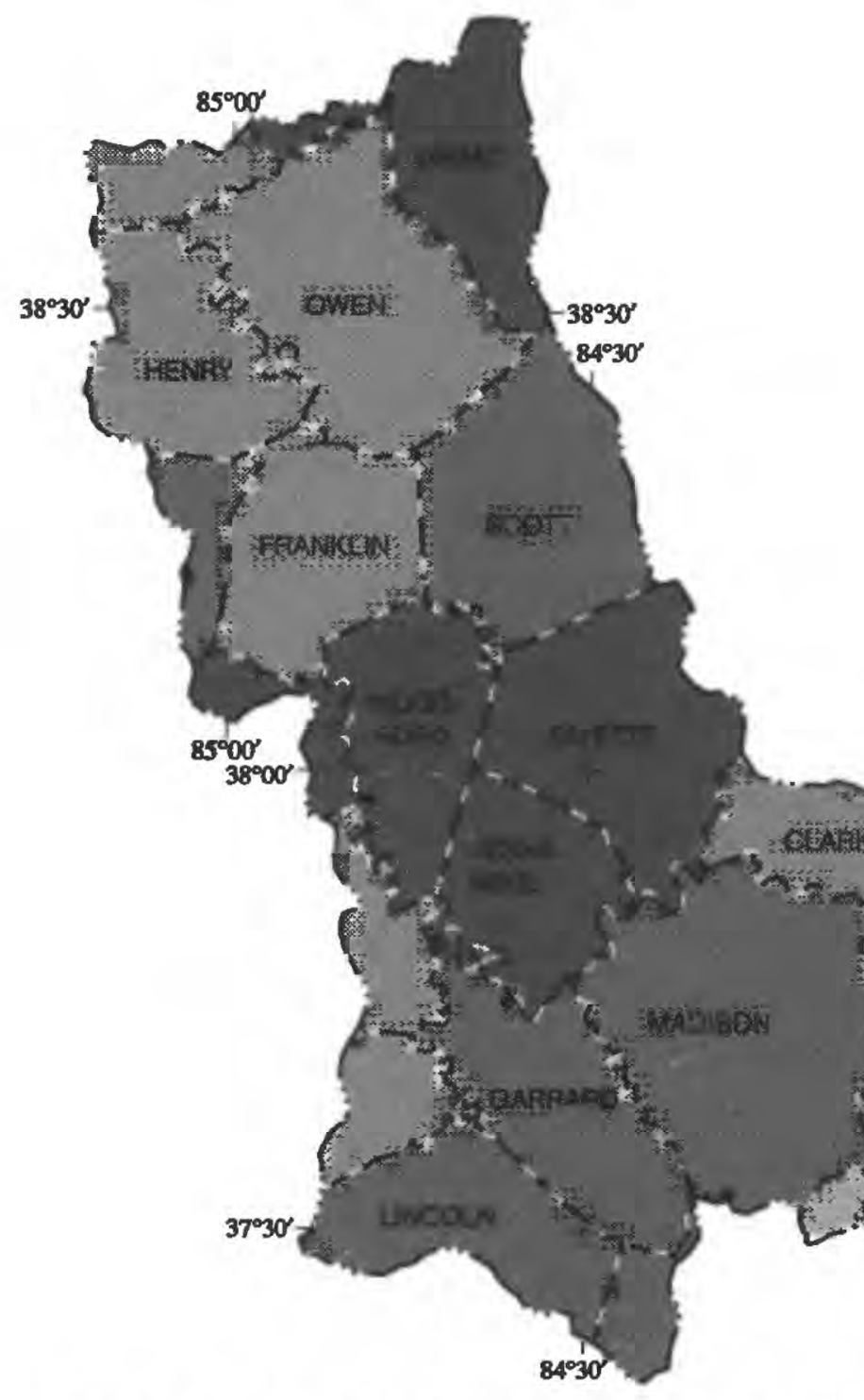

Base from U.S. Geological Survey digital data, 1:100,000, 1983 Universal Transverse Mercator projection, Zone 16

\section{EXPLANATION \\ POPULATION CHANGE, IN PERCENT}

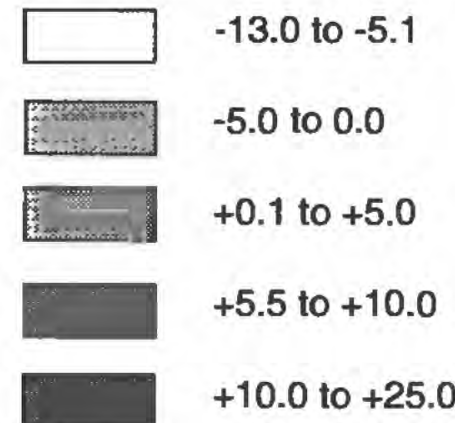

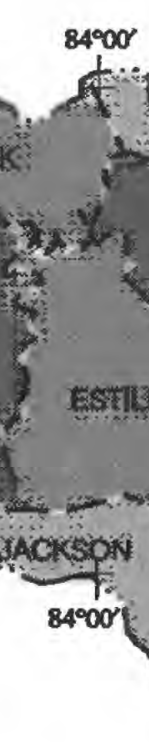
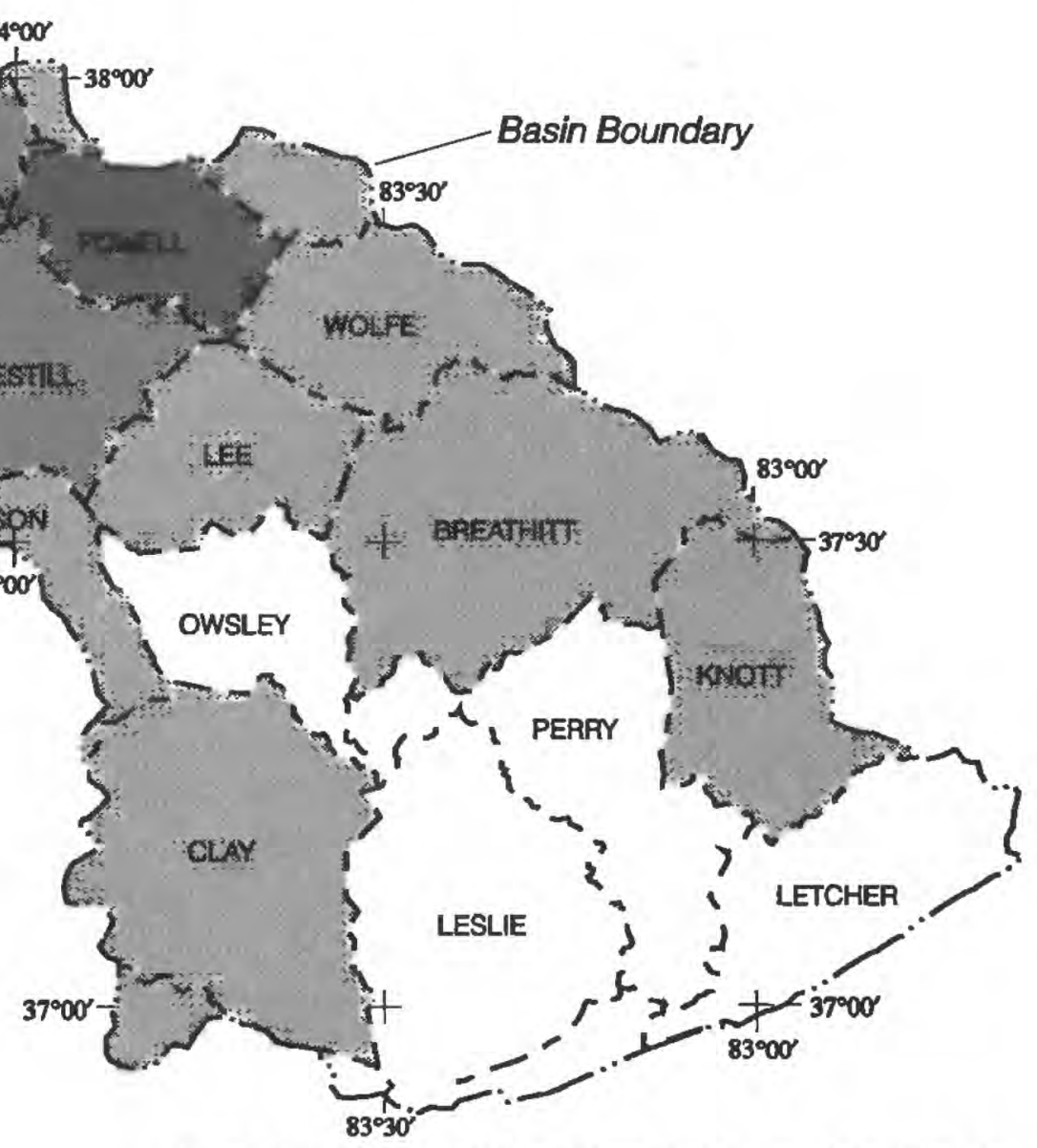

Population data from Kentucky Economic Statistics, Department of Existing Business and Industry, Division of Research and
Planning, 1991

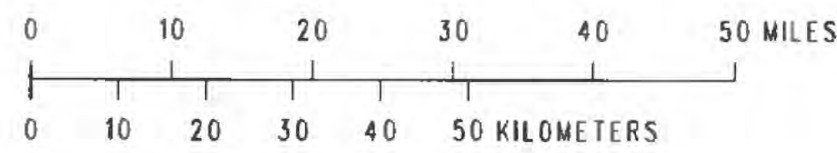

Figure 6. Changes in population in counties in the Kentucky River Basin from 1980 to 1990. 
Major land uses include forestry, agriculture, coal mining, and oil and gas production; the amount of urban land also is substantial (Smoot and others, 1991). Forests make up more than 50 percent of the basin land area, although they are concentrated principally in the Eastern Coal Field Region. More than 90 percent of the timber volume is hardwood species, principally hickory and poplar; the remainder consists of pines and eastern red cedar. Approximately 40 percent of the basin is devoted to agriculture, primarily in the Inner and Outer Bluegrass Regions. Corn, soybeans, wheat, and tobacco are the dominant crops, and livestock includes horses, dairy and beef cattle, poultry, sheep, and goats. Bituminous coal is mined in the Eastern Coal Field Region and about 25 percent of the State's coal production is from the Kentucky River Basin. Oil and gas production are confined to the Knobs Region. Principal municipalities include Carrollton, Frankfort, Georgetown, Lexington, Danville, Richmond, and Hazard.

\section{Water Use}

In the Kentucky River Basin, water withdrawal differs considerably among subbasins, ranging from $1.66 \mathrm{Mgal} / \mathrm{d}$ in the Middle Fork Kentucky River to $70.04 \mathrm{Mgal} / \mathrm{d}$ in the lower Kentucky River. In all subbasins, the principal use of water withdrawn from surface supplies is for potable water supply. Surface water provides 95 percent of the public water supply basinwide. The largest municipalities supplying water are Lexington, Frankfort, and Richmond. Other water uses include industrial supply, recreation, commercial navigation, and propagation of fish and wildlife. The demand for water in the Bluegrass Region increased almost 20 percent between 1982 (64 Mgal/d) and 1987 (76 Mgal/d) (Don Hassall, Bluegrass Area Development District, written commun., 1992).

A total of 11 municipal wastewater-treatment facilities discharge more than $1 \mathrm{Mgal} / \mathrm{d}$ of effluent into the Kentucky River Basin. In addition, 30 small municipal wastewater-treatment plants each discharge wastewater quantities of less than $1 \mathrm{Mgal} / \mathrm{d}$. Approximately 250 small nonmunicipal wastewater-treatment facilities are permitted to operate within the Kentucky River Basin. At least 29 industrial facilities discharge more than $1 \mathrm{Mgal} / \mathrm{d}$ of wastewater to surface waters in the Kentucky River Basin.

\section{CONSTITUENT SOURCES AND EFFECTS ON SURFACE-WATER QUALITY}

Nutrients, sediments, and pesticides were identified as high-priority water-quality issues in the NAWQA program by the USGS in conjunction with Federal, state, and local agencies and with the input of the NAWQA advisory council. A brief description of these constituents and a general summary of their occurrence and behavior in aquatic ecosystems are provided in this section.

\section{Nutrients}

Nutrients are essential to the ecological functioning of all ecosystems. Aquatic ecosystems depend on the conversion of solar energy into energy-rich 
organic molecules by primary producers such as algae and higher plants. Primary producers, in turn, are consumed by herbivores and omnivores, which transform and transfer energy through the system. The sustained growth of freshwater algae and higher plants requires a supply of nutrients (Smith, 1979, 1983), principally phosphorus and nitrogen, which are derived from precipitation and runoff from the land surface. Various biogeochemical processes serve to recycle nutrients and other minerals throughout the aquatic ecosystem.

Phosphorus is most often the limiting nutrient for growth of aquatic algae and other primary producers in aquatic systems. Inorganic phosphorus or orthophosphate--present primarily as fluorapatite, $\mathrm{Fl}_{3} \mathrm{Ca}_{5}\left(\mathrm{PO}_{4}\right)-$ is abundant in soils that originate from phosphatic limestone. Inorganic fertilizer applied to agricultural and domestic crops is another significant source of inorganic phosphorus. Organic phosphates, known as metaphosphates or polyphosphates, are derived principally from human and animal wastes that include decaying plant and animal material, sewage effluent, and septic-tank leachate. Dissolved phosphorus is readily taken up by photosynthetic organisms in surface waters, so concentrations in pristine waters seldom exceed a few tenths of a milligram per liter (Hem, 1985). Excess phosphorus can result in algal blooms, which are aesthetically unappealing and may cause taste and odor problems in waters serving as drinking-water sources. Decomposition of algal blooms causes depletion of dissolved oxygen, to the detriment of associated aquatic biota.

Nitrogen is the other principal nutrient essential for plant growth. Nitrogen is available to algae and higher plants in several forms in aquatic systems, including ammonia, nitrite, and nitrate. Interconversion of these forms is usually mediated by biota, principally microorganisms. Among the major human sources of nitrogen are municipal and industrial wastewater, feedlot runoff, inorganic fertilizers, leachate from landfills, and atmospheric deposition. Natural sources of nitrogen include fixation of atmospheric nitrogen by blue-green algae and the Rhizobium group of bacteria. Nitrogen concentrations in pristine waters are typically less than $1 \mathrm{mg} / \mathrm{L}$ (Hem, 1985). Excess nitrogen results in overabundance of algae, which can cause taste and odor problems as well as depletion of dissolved oxygen. Excessive nitrate concentrations in drinking water also pose a threat to human health.

\section{Sediments}

Fluvial sediment is defined as fragmentary material that originates primarily from weathering of rocks and is transported by, suspended in, or deposited from water (Federal Interagency Sedimentation Project, 1963). Fluvial sediment includes chemical and biological precipitates, as well as decomposed organic material (Edwards and Glysson, 1988). Sheet and channel erosion are the principal processes by which sediment particles enter into surface waters. Erosion is a function of land cover, surface slope, soil erodibility, and precipitation intensity. Fine sediments such as silt and clay move downstream at roughly the same velocity as the water and are kept in suspension by turbulence, whereas the coarser sediments are transported only occasionally during high flows. 
Aquatic biota can be dislodged by scour and smothered by sediment transported and deposited by flowing water. Elevated suspended-sediment concentrations can render water aesthetically unsatisfactory for recreational use. The ability of suspended-sediment particles to adsorb nutrients and pesticides and other manmade organic compounds can lead to accelerated dispersal and accumulation of these constituents in streams (Smith and others, 1988; Adams and others, 1992). Alternatively, if toxic substances remain sorbed to fine-grained sediments and are less available to biota for accumulation and transfer up the food chain, then sorption to sediments may be beneficial. The fate of contaminated sediments is not well understood, however, and long-term changes in resuspension, mobilization, and dissolution are uncertain (American Society of Civil Engineers, Task Committee on Sediment Transport and Aquatic Habitats, Sedimentation Committee, 1992).

\section{Pesticides}

Herbicides are the most widely used agricultural pesticides in the United States and are a1so applied in urban settings. More than 120 chemicals are registered for herbicide use, and many formulations include numerous additives, adjuvants, and associated compounds. The postapplication residual life of herbicides ranges from a few days to more than a year, depending on the compound, soil type, and environmental conditions. A number of the triazines, which are nitrogen-containing herbicides, sorb readily to the soil and leach slowly in soils with more than 1 percent organic matter. Atrazine is the most commonly used herbicide in this class, which also includes simazine and metribuzin. Numerous other herbicides are widely used in agricultural settings, among them 2,4-D, alachlor, metolachlor, and dicamba.

Many insecticides are used in agricultural and residential settings. The fate of these compounds is affected by several environmentally dependent processes such as solubilization, runoff, leaching, bioaccumulation, and degradation (Biggar and Seiber, 1987). Principal classes of insecticides are chlorinated hydrocarbons, organophosphates, carbamates, and pyrethroids. Chlorinated hydrocarbons such as DDT, DDD, and methoxychlor are persistent in the environment and tend to accumulate in tissues and sediments because of their hydrophobic nature.

\section{ASSESSMENT APPROACH}

Water-quality data for the Kentucky River Basin NAWQA pilot study were collected and analyzed to determine (1) the spatial, temporal, and streamflowrelated variability of constituents throughout the basin; (2) the effects of point-source discharges such as municipal and industrial effluents, on water quality; and (3) the effects of runoff from nonpoint sources, such as agricultural operations, on water-quality conditions. The target variables selected were constituents that are relevant to local, regional, or national water-quality issues, including nutrient enrichment, sedimentation, chemical contamination, and overall acceptability of water for use (Hirsch and others, 1988). 


\section{Design of Field Investigations}

The Kentucky River Basin assessment of nutrients focused on point- and nonpoint-source contamination that may significantly affect relatively long reaches of principal streams of the basin. Constituents of interest included nitrate, nitrite, and ammonia nitrogen, as well as orthophosphate and phosphorus (Griffin and others, 1994). Fixed-station sampling and two synoptic studies were done to assess spatial and temporal distribution of these constituents.

Seven fixed stations were located within the basin (fig. 7; table 1). These stations were selected after consideration of variations in geographic and hydrographic resolution, major tributaries, land use, water use, and the availability of historic water-quality or streamflow data. Special consideration was given to locations upstream from major public-water-supply intakes, below urban or industrial areas, and in relatively homogenous subbasins. Fixed stations were sampled monthly for specific target constituents over a 3-year period from April 1987 through March 1990. Additional high-flow sampling was also done at these stations, generally at times when streamflow exceeded a flow duration of 10 percent. These high-flow data were required to improve the accuracy of constituent-load estimates because constituent-load transport often is greatest during high-flow periods (Griffin and others, 1994). A detailed description of station locations, sample collection, WATSTORE codes and detection levels for constituents at the fixed-station network in the Kentucky River Basin has been compiled by Griffin and others (1994).

Synoptic studies (studies that involve nearly simultaneous measurements at multiple sites) were done to evaluate water quality for a brief period of time over a broad geographical area. Single samples were taken at many sites to provide information on the occurrence and distribution of selected nutrients during stable, low-flow conditions when the effects of point-source discharges predominate. A total of 74 sites were sampled during August 24-28, 1987; and 74 sites were sampled during August 8-12, 1988. Sites were selected on the basis of physiography, land use, point-source discharges, and separations from one another of no more than 25 river miles (table 2, fig. 8). Nutrient samples from the fixed stations and synoptic sites were analyzed for concentrations of total phosphorus, dissolved phosphorus, ammonia nitrogen plus total organic nitrogen, ammonia nitrogen plus dissolved organic nitrogen, dissolved ammonia nitrogen, dissolved nitrate plus nitrate nitrogen, and dissolved nitrate nitrogen.

Relations among nutrients and algae in the Kentucky River Basin were assessed by collecting monthly phytoplankton samples from October 1987 through August 1988 at the seven fixed stations. Water samples were collected concurrently with algal samples and analyzed to determine $\mathrm{pH}$ and dissolvedoxygen concentration. The majority of the algae and associated water samples collected at the fixed stations ( 322 of 357 ) were collected between 8:00 a.m. and 4:30 p.m., but it was not possible to collect the samples at a consistent time of day during the 3-year study. Algae samples at the fixed stations were supplemented with algae samples collected during the synoptic surveys in August 1987 and August 1988. These algae samples and associated water samples were also generally collected between $8: 00 \mathrm{a} \cdot \mathrm{m}$. and 4:30 p.m. 


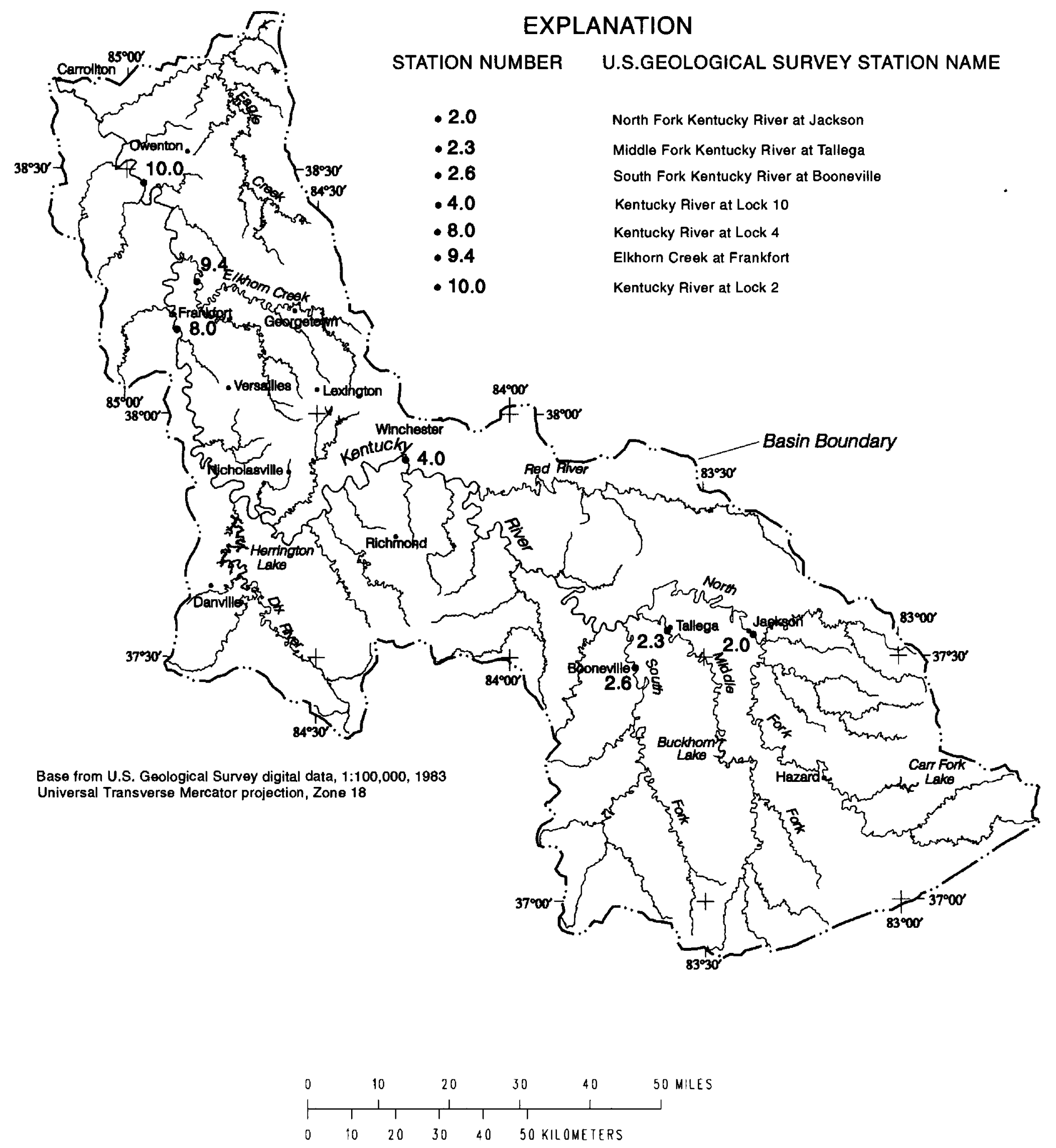

Figure 7. Location of fixed stations in the Kentucky River Basin. 
Table 1. Characterization of the seven fixed stations in the Kentucky River Basin

$\left[\mathrm{mi}^{2}\right.$, square miles; $\mathrm{ft}^{3} / \mathrm{s}$, cubic feet per second; $(\mathrm{ft} / \mathrm{s}) / \mathrm{mi}^{2}$, cubic feet per second per square mile; data from Melcher and Ruhl, 1984]

\begin{tabular}{|c|c|c|c|c|}
\hline $\begin{array}{c}\text { Station name } \\
\text { (Station number) }\end{array}$ & $\begin{array}{l}\text { Drainage } \\
\text { area } \\
\left(\mathrm{mi}^{2}\right)\end{array}$ & $\begin{array}{l}\text { Average } \\
\text { discharge } \\
\left(\mathrm{ft} t^{3} / \mathrm{s}\right)\end{array}$ & $\begin{array}{l}7 \text {-day } \\
10 \text {-year } \\
\text { low flow } \\
(\mathrm{ft} / \mathrm{s})\end{array}$ & $\begin{array}{l}\text { Average } \\
\text { specific } \\
\text { discharge } \\
{\left[\left(f t^{3} / \mathrm{s}\right) / \mathrm{mi}^{2}\right]}\end{array}$ \\
\hline $\begin{array}{l}\text { North Fork Kentucky } \\
\text { River at Jackson } \\
(2.0)\end{array}$ & 1,101 & 1,360 & 3.1 & 1.24 \\
\hline $\begin{array}{l}\text { Middle Fork Kentucky } \\
\text { River at Tallega } \\
(2.3)\end{array}$ & 537 & 730 & .6 & 1.36 \\
\hline $\begin{array}{l}\text { South Fork Kentucky } \\
\text { River at Booneville } \\
(2.6)\end{array}$ & 722 & 1,060 & 1.1 & 1.47 \\
\hline $\begin{array}{l}\text { Kentucky River at } \\
\text { Lock } 10 \text {, near Winchester } \\
(4.0)\end{array}$ & 3,955 & 5,271 & 42.0 & 1.33 \\
\hline $\begin{array}{l}\text { Kentucky River at } \\
\text { Lock 4, near Frankfort } \\
(8.0)\end{array}$ & 5,410 & 7,110 & 175.0 & 1.31 \\
\hline $\begin{array}{l}\text { Elkhorn Creek at } \\
\text { Frankfort } \\
(9.4)\end{array}$ & 473 & 609 & 6.5 & 1.29 \\
\hline $\begin{array}{l}\text { Kentucky River at } \\
\text { Lock 2, near Lockport } \\
(10.0)\end{array}$ & 6,180 & 8,320 & 206.0 & 1.35 \\
\hline
\end{tabular}


Tabla 2. Location of synoptic sites in the Kentucky River Basin

["Synoptic site code" corresponds to sempling sites shown in figure 8; "site number" refers to U.S. Geological Survey downstream-order number]

\begin{tabular}{|c|c|c|c|c|c|}
\hline $\begin{array}{l}\text { site } \\
\text { number }\end{array}$ & site neme & $\begin{array}{l}\text { Synopt ic } \\
\text { site } \\
\text { code }\end{array}$ & $\begin{array}{l}\text { Drainage } \\
\text { area, } \\
\text { in square } \\
\text { miles }\end{array}$ & Lati tude ${ }^{1}$ & Long i tude ${ }^{1}$ \\
\hline 03277305 & N Fk Ky R at Ice & AA & 85 & 370632 & 825149 \\
\hline 03277360 & Rockhouse $\mathrm{Cr} \mathrm{nr}$ Letcher & $\mathbf{A B}$ & 51.5 & 370910 & 825628 \\
\hline 03277410 & Leatherwood $\mathrm{Cr}$ at Cornettsville & $A C$ & 49.7 & 370735 & 830505 \\
\hline 03277470 & Carr Fork at Scuddy & $A D$ & 79.7 & 371209 & 830513 \\
\hline 03277550 & N Fk Ky R at Combs & BA & 480 & 371558 & 831303 \\
\hline 03277690 & N Fk Ky R at Chavies & CA & 575 & 372052 & 832112 \\
\hline 03277835 & Troublesome $\mathrm{Cr}$ At Dwarf & $\mathrm{CB}$ & 59.9 & 372030 & 830707 \\
\hline 03279005 & Troublesome $\mathrm{Cr} \mathrm{nr}$ Clayhole & CC & 195 & 372802 & 831647 \\
\hline 03279400 & Quicksand $\mathrm{Cr}$ at Lunah & $\mathrm{CD}$ & 101 & 373331 & 831104 \\
\hline 03279700 & Quicksand $\mathrm{Cr}$ at Quicksand & CE & 203 & 373211 & 832055 \\
\hline 03280000 & N Fk Ky R at Jackson & DA & 1,101 & 373246 & 832221 \\
\hline 03280120 & N Fk KY R at Frozen Creek & EA & 1,134 & 373534 & 832523 \\
\hline 03280500 & N Fk Ky R nr Airdale & FA & 1,294 & 373700 & 833800 \\
\hline 03280551 & M Fk KY R at Asher & $\mathbf{F B}$ & 70.6 & 370310 & 832400 \\
\hline 03280600 & M Fk Ky R nr Hyden & FC & 202 & 370813 & 832217 \\
\hline 03280700 & Cutshin $\mathrm{Cr}$ at Wooton & FD & 61.3 & 370954 & 831829 \\
\hline 03280900 & M Fk Ky R at Buckhorn & FE & 420 & 372045 & 832807 \\
\hline 03280940 & M Fk Ky R nr Shoulderblade & $\mathbf{F F}$ & 475 & 372914 & 832850 \\
\hline 03281000 & M Fk Ky R at Tallega & FG & 537 & 373318 & 833538 \\
\hline 03281017 & Red Bird R nr Spring Creek & FH & 53 & 370253 & 833239 \\
\hline 03281040 & Red Bird R nr Big Creek & FI & 155 & 371043 & 833535 \\
\hline 03281100 & Goose $\mathrm{Cr}$ at Manchester & FJ & 163 & 370907 & 834537 \\
\hline 03281200 & S Fk Ky R at Oneida & FK & 486 & 371623 & 833850 \\
\hline 03281351 & Sexton $\mathrm{Cr} \mathrm{nr}$ Taft & $\mathbf{F L}$ & 71.6 & 372133 & 834059 \\
\hline 03281500 & S Fk KY R at Booneville & FM & 722 & 372845 & 834038 \\
\hline 03282000 & Ky $R$ at Lock 14, Heidelberg & GA & 2,657 & 373319 & 834606 \\
\hline 03282048 & Sturgeon $\mathrm{Cr} \mathrm{nr}$ Ida May & GB & 110 & 373215 & 834658 \\
\hline 03282075 & Big sinking $\mathrm{Cr}$ nr Crystal & GC & 23.4 & 373822 & 834705 \\
\hline 03282100 & Furnace Fk nr Crystal & GD & 9.94 & 374121 & 835127 \\
\hline 03282170 & Station Camp $\mathrm{Cr}$ at Wagersville & GE & 116 & 373715 & 835734 \\
\hline 03282190 & Redlick $\mathrm{Cr} \mathrm{nr}$ station Camp & GF & 69.5 & 373801 & 835901 \\
\hline 03282250 & Ky $R$ at Irvine & HA & 3,138 & 374155 & 835832 \\
\hline 03282500 & Red R $\mathrm{nr}$ Hazel Green & HB & 65.8 & 374844 & 832750 \\
\hline 03283200 & Red $R$ at Highway 77 & HC & 184 & 375000 & 833936 \\
\hline 03283320 & M Fk Red R nr Slade & HD & 25.4 & 374814 & 834233 \\
\hline 03283370 & Cat $\mathrm{Cr} \mathrm{nr}$ stanton & HE & 8.30 & 374955 & 834841 \\
\hline 03283500 & Red $R$ at Clay City & HF & 362 & 375153 & 835601 \\
\hline 03283815 & Ky R nr Doylesville & IA & 3,771 & 375140 & 840940 \\
\hline 03283820 & Muddy $\mathrm{Cr}$ at Elliston & IB & 37.0 & 374427 & 840922 \\
\hline
\end{tabular}


Table 2. Location of synoptic sites in the Kentucky River Basin--Cont inued

["Synoptic site code" corresponds to sampling sites shown in figure B; "site number" refers to U.S. Geological Survey downstrean-order number]

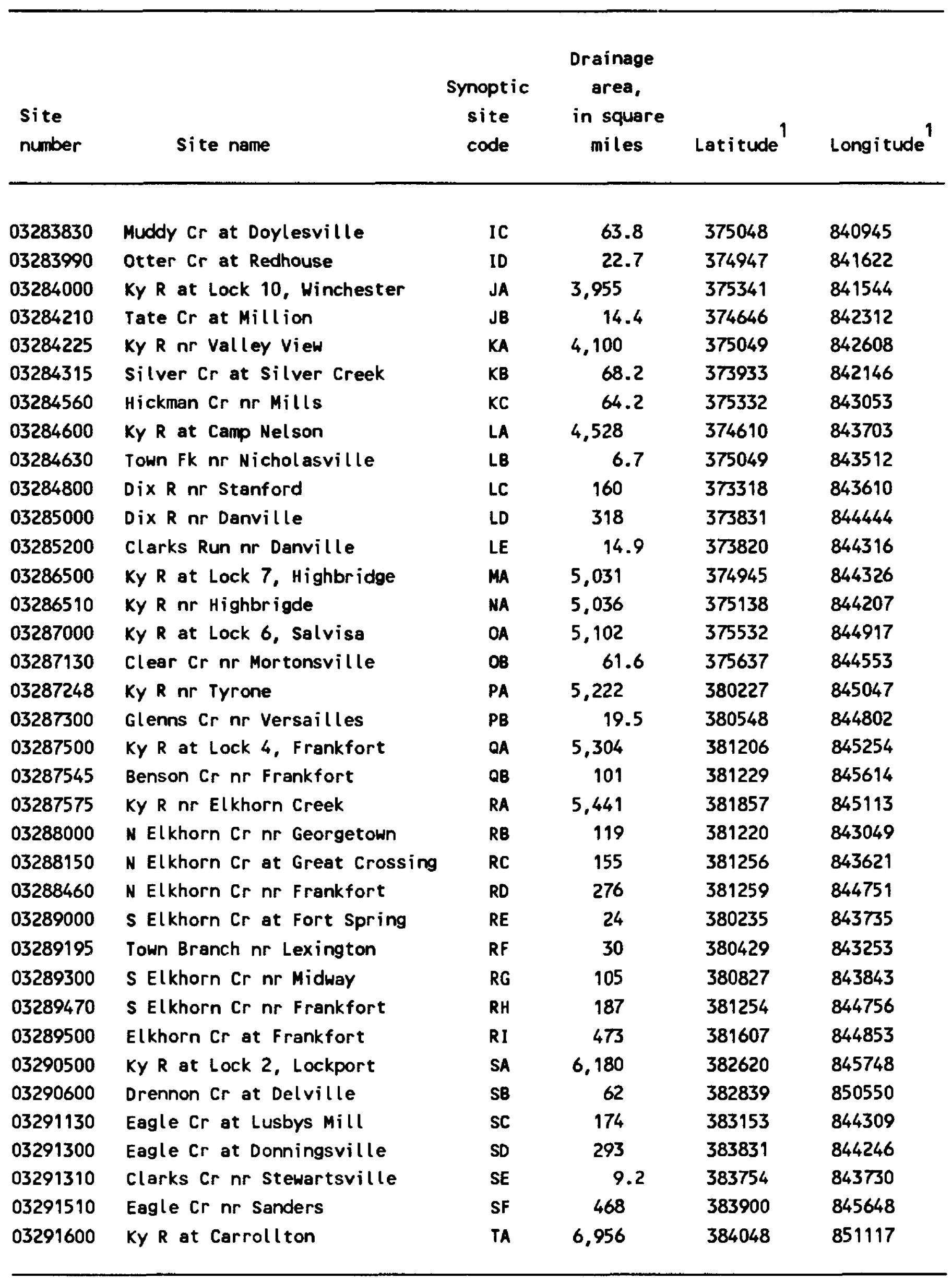

${ }^{1}$ Degree, minute, and second symbols are omitted. 


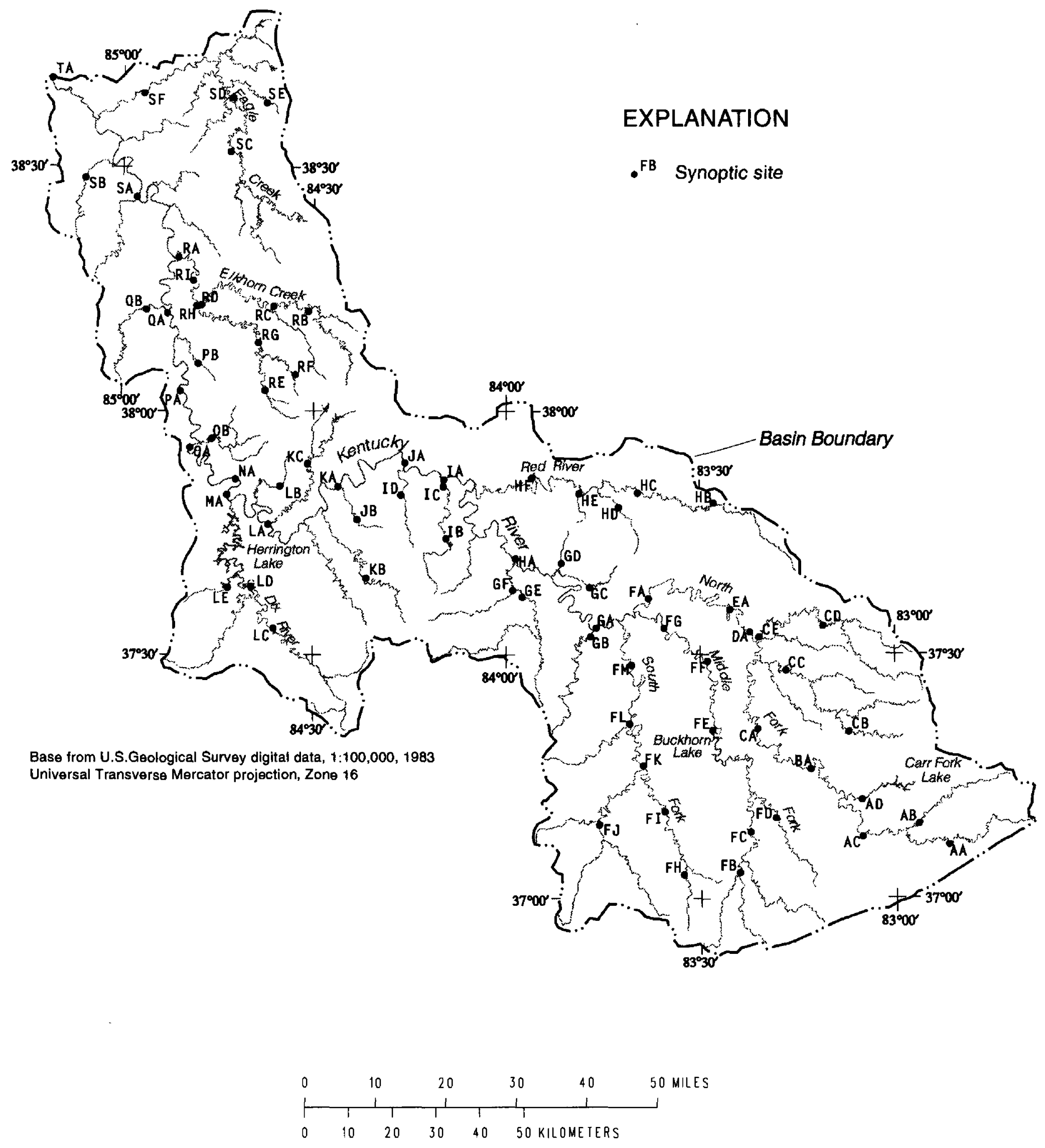

Figure 8. Location of synoptic sites in the Kentucky River Basin sampled during August 24-28, 1987, and August 8-12, 1988. 
Samples for phytoplankton analyses were collected by the equal-dischargeincrement/equal-width-increment (EDI/EWI) method described by Ward and Harr (1990). Subsamples for phytoplankton were withdrawn from the same water sample collected for nutrient determinations. Phytoplankton samples were processed in the field as described by Britton and Greeson (1989) and transported to the University of Louisville Biology Department for analyses of chlorophyl1 a content and phytoplankton-community composition. Chlorophyl1 a concentration was determined by the fluorometric method, as described by Weber (1973) and Clesceri and others (1989). Phytoplankton-community composition was determined by identifying and enumerating a minimum of 500 algal cells from each sample.

Suspended sediment was collected monthly at the seven fixed stations for the 3-year study period. Sediment samples were also collected during multiple high-flow events because of the demonstrated effect of high flows on annual load estimates (Singh and Durgunoglu, 1992). In addition, suspended-sediment data were collected during each of the nutrient synoptic surveys in 1987 and 1988.

The pesticide assessment included multiple components. During the water years 1988-89, selected sampling for hydrophilic pesticides was done at 14 sites in the basin. Sampling for chlorophenoxy acid and triazine herbicides and organophosphorus insecticides was done during runoff events to identify and quantify specific compounds and classes of compounds in surface waters. During runoff events in the summer to early fall of 1990, nine sites were sampled for chlorophenoxy acid and triazine herbicides and for organophosphorus and carbamate insecticides. A fixed-station, fixed-interval (every 2 months) sampling network was maintained during water year 1991 at four sites in the basin; the samples were analyzed for chlorophenoxy acid herbicides, dicamba, picloram, and triazine herbicides. A low-flow synoptic survey was done in November 1988 to determine the occurrence and distribution of organochlorine compounds in streambed sediments at 26 locations in the basin.

\section{Methods of Sample Collection and Processing}

Water samples for nutrients and suspended sediment were collected by use of a USGS D-77 or DH-81 sediment sampler and a cross-section-integrated sampling method. The sediment samplers are designed to collect a sample that represents the width and depth of a stream cross section. The cross-sectionintegrated sampling method is described as an equal-width-increment (EWI) method (Guy and Norman, 1970; Ward and Harr, 1990). At least seven verticals were sampled at each station during this study, except during high flows, when four to five verticals were sufficient. Additional details can be found in Griffin and others (1994).

At each cross section, water samples from all verticals were composited into a $14 \mathrm{~L}$ churn splitter for processing. Composited samples to be analyzed for total concentrations of nutrients, suspended sediments, and pesticides were transferred directly from the churn splitter to their respective containers. Samples for the analysis of dissolved constituents were passed through a $0.45 \mu \mathrm{m}$ polycarbonate filter by use of a peristaltic pump. 
Additional details of sample collection and processing can be found in Ward and Harr (1990).

Composited surficial streambed-sediment samples were collected from small and large streams during the low-flow synoptic study in the fall of 1987 . The fine-fraction $(<63 \mu \mathrm{m})$ sediments submitted for chemical analyses were collected by dry sieving at sites on small streams and by wet sieving at sites on large streams (S.D. Porter, U.S. Geological Survey, written commun., 1993).

\section{Methods of Laboratory Analyses}

U.S. Geological Survey laboratory methods for nutrient and suspendedsediment analyses are described in Fishman and Friedman (1989). Methods for analysis of pesticides are described by Wershaw and others (1987). All chemical analyses on water and water-sediment mixtures were done in the USGS National Water Quality Laboratory in Arvada, Colo. The size distribution of the sand and finer fraction of suspended sediment was analyzed by the USGS sediment laboratory in Louisville, Ky.

\section{Methods of Data Analysis and Storage}

Censored data (individual measurements "less than" analytical limits of detection) were set to the indicated detection limit or fit to a log-normal distribution depending on the type of analysis to be done (He1sel, 1991). Statistical analyses were done by use of System for Statistics (SYSTAT) ${ }^{1}$ (Wilkinson, 1989). The use of the term "significant" in this report indicates that the probability of Type I statistical error was less than 5 percent $(p<0.05)$. Statistical correlations are discussed only if the absolute value of the correlation coefficient $(r)$ exceeded $0.75(r>0.75)$.

Boxplots (Tukey, 1977) were constructed to provide graphical displays of the median, interquartile range, quartile skew, and extreme data values for selected constituents. A boxplot was not constructed if fewer than 10 observations for a site were available. Boxplots consist of a box drawn from the 25 th percentile to the 75 th percentile (the interquartile range). A horizontal line is drawn across the box at the median, and the two box parts thus depict the quartile skew. Vertical lines (whiskers) are drawn from the quartiles to the largest data value less than or equal to the upper quartile plus 1.5 times the interquartile range (upper adjacent value) and the smallest data value greater than or equal to the lower quartile minus 1.5 times the interquartile range (lower adjacent value). Values more extreme in either direction than these values are plotted individually. Those from 1.5 to 3.0 times the interquartile range (outside values) are plotted with an asterisk. Data more extreme than 3.0 times the interquartile range (faroutside values) are plotted with a circle.

${ }^{1}$ Any use of trade, product, or firm names in this publication is for descriptive purposes only and does not constitute endorsement by the U.S. Geological Survey. 
Relations among nutrients and chlorophyl1 a concentrations and the effects of phytoplankton processes on other water-quality conditions were evaluated by pairwise correlations with nutrient chemistry, Do concentration, and $\mathrm{pH}$. Data were $\log$ transformed where necessary to normalize the data and meet the assumptions of statistical tests. The net rate of oxygen production (NROP) by algae was estimated by measuring the DO concentration before sunrise (minimum), subtracting this value from a second DO measurement made during midmorning to late morning, and dividing the result by the amount of time that had elapsed between measurements, as follows:

$$
\mathrm{NROP}=\mathrm{DO} / \Delta \mathrm{t},
$$

where NROP is the rate of oxygen production, in milligrams of dissolved oxygen per liter per hour;

Do is the change in dissolved oxygen concentration; and, $\Delta t$ is the time interval, in hours.

This calculation provides an estimate of net primary productivity but does not account for rates of oxygen diffusion, which are a function of water temperature and the difference in oxygen saturation between water and air (Odum, 1956).

Water-quality data collected during the study were stored in files of the USGS National Water Storage and Retrieval System (WATSTORE) and the National Water Information System--85.1 (NWIS) data bases (Hutchinson, 1975; Edwards and others, 1986).

\section{Quality Assurance}

The guidelines for quality assurance and quality control (QA/QC) in the NAWQA program are outlined in Mattraw and others (1989). Specific QA/QC procedures in practice during the Kentucky River Basin pilot study are described by Griffin and others (1994). Sample duplicates were collected for nutrient and suspended-sediment analysis at the fixed sites to assess samplecollection variability. Results are reported by Griffin and others (1994). Analytical laboratory QA/QC practices are detailed by Friedman and Erdmann (1983) and Fishman and Friedman (1989). The USGS National Water Quality Laboratory quality-assurance practices are described by Jones (1987).

\section{Compilation and Analysis of Ancillary Data}

Ancillary data were collected from a variety of sources to identify the factors affecting surface-water quality in the Kentucky River Basin. A small amount of data on the $\mathrm{pH}$ and chemistry of precipitation near the Kentucky River Basin was collected at four sites by the National Atmospheric Deposition Program in 1990 (National Atmospheric Deposition Program, 1991). For purposes of this report, values reported for sites in Letcher, Rowan, and Washington Counties (the latter two counties are located near but not in the Kentucky River Basin) were considered in calculating ranges of annual mean concentrations of ammonia and nitrate in precipitation and dry fall (L.J. Puckett, U.S. Geological Survey, written commun., 1992). 
The KDOW has compiled an extensive data base on water quality. KDOW data cited or used in this report were collected during 1975-86 (Smoot and others, 1991) at the following locations: North Fork of the Kentucky River at Jackson; Middle Fork Kentucky River at Tallega; South Fork Kentucky River at Booneville; and in the main stem of the Kentucky River at Lock 4 at Frankfort. These stations are hereafter referred to as "paired stations." The KDOW routinely collects water-quality data by surface-grab sampling, whereby samples are collected in an open container from a single point at or near the stream surface. Detailed information on collection methods and quality assurance have been published (Kentucky Natural Resources and Environmental Protection Cabinet, 1988a). Surface-grab samples would not be expected to be an accurate representation of nonuniform water-quality conditions in a stream cross section, particularly with respect to suspended-sediment and sedimentassociated constituents. Therefore, concentrations of water-quality constituents reported by the KDOW typically will be different than concentrations of water-quality constituents collected from paired stations by means of the cross-sectionally integrated, flow-weighted composite sampling used by the USGS (Martin and others, 1993).

Data characterizing the effluent water quality from individual WWTP's were summarized from Discharge Monitoring Reports (DMR) required for pointsource discharges by the KDOW under the Kentucky Pollution Discharge Elimination System (KPDES) program. The DMR data used to estimate instantaneous discharge and instantaneous ammonia nitrogen loads in this report were those collected in 1991 during the month closest to the synoptic surveys in August 1987 and 1988, because DMR data for 1987 and 1988 were not available. The percentage of stream discharge and stream nitrogen load attributable to WWTP effluent in 1987 and 1988 was then estimated in subbasins of the Kentucky River Basin based on the available DMR data. The instantaneous nitrogen load from WWTP effluent was conservatively estimated and was assumed to be equal to the instantaneous effluent load of ammonia as reported in DMR. These estimates may underestimate the actual effluent load of ammonia as reported in DMR if WWTP's treat effluent ammonia prior to discharge; however, data on the extent of ammonia treatment were not available.

The sources of the land use data in this report are the 1983 National Atmospheric and Space Administration high-altitude aerial photographs and National High-Altitude Photography program photographs digitized at a scale of $1: 250,000$ (U.S. Geological Survey, 1986). These data were used to assign a dominant land use type for the subbasins upstream of each fixed station, and also for each subbasin upstream of each of the synoptic sites. Although the land-use data base lacked sufficient resolution for some types of analyses, it provided the best data available at the time of the study.

In correlation analyses involving land use in subbasins upstream from the synoptic sites, a weighting factor was used to assign the dominant land use. Land use was labeled "forest" in a subbasin if the proportion of forested land was greater then 50 percent. Land use was labeled "agriculture" if the proportion of agricultural 1 and was greater than 50 percent and the proportion of urban land was less than 13 percent. Land use was labeled "urban" if the proportion of urban land use was greater than 13 percent. 
Estimates of crop acreage and livestock numbers in the Kentucky River Basin are based on data collected by the U.S. Department of Agriculture (USDA) 1982 Census of Agriculture. This information has been updated with information available in the "Kentucky Agricultural Statistics 1990-1991" handbook (Kentucky Agricultural Statistics Service, 1991).

The Environmental Resources Branch (ERB) of the Office of Policy Analysis, U.S. Environmental Protection Agency (USEPA), has developed a data base of commercial fertilizer sales information, at the county level, for the period June 1986-July 1987. The data for Kentucky, which include nitrogen, phosphorus, and potash, were provided by the National Fertilizer Development Center of the Tennessee Valley Authority. The data set contains fertilizer sales by the season of sale; namely, spring (January through June) and fall (July through December). Amounts of the various forms of nitrogen fertilizer, including ammonium nitrate, anhydrous ammonia, nitrogen solutions, urea, and miscellaneous other forms, also are identified.

The Cooperative Extension Service of the University of Kentucky College of Agriculture has compiled data on pesticide use by Kentucky certified applicators. The Kentucky Division of Pesticides has developed a "LAWN" data base that contains information on agrichemicals applied by lawn-care companies that serve urban residential and commercial customers. The file contains application-rate data by county for calender year 1990 .

Resources for the Future (RFF), Renewable Resources Division, has developed estimates for pesticide use in the Kentucky River Basin (Gianessi, 1986). These estimates are drawn from the RFF National Pesticide Usage Inventory. The inventory consists of 184 pesticides, in terms of their active ingredients, applied to 76 cropland types and 2 noncropland uses (nurseries and urban applicators) for the year 1982. Data are available by county and by hydrologic unit.

\section{ASSESSMENT OF NUTRIENTS, SEDIMENTS, AND PESTICIDES IN STREAMS}

\section{Nutrients}

The spatial distribution and temporal variability of nutrients in streams of the Kentucky River Basin was assessed by collecting water samples monthly at 7 fixed stations during the entire study period and at 74 synoptic sites during low-flow periods in August 1987 and August 1988. Ancillary data on the potential sources of nutrients in the basin also were compiled and analyzed.

\section{Basin-Scale Distribution}

The basin-scale distribution of phosphorus and nitrogen forms was assessed by collecting data at the seven fixed stations during 1987-90. Comparable data for these constituents collected by the KDOW during 1986-89 are included for purposes of discussion. 
Spatial and temporal distribution

Average concentrations of dissolved orthophosphorus ranged from a minimum of less than $0.01 \mathrm{mg} / \mathrm{L}$ at several of the upstream fixed stations to a high of $2.3 \mathrm{mg} / \mathrm{L}$ in Elkhorn Creek (table 3). Concentrations found in Elkhorn Creek were significantly higher than concentrations at any of the other fixed stations. Concentrations of total phosphorus ranged from less than $0.01 \mathrm{mg} / \mathrm{L}$ at stations upstream from Lock 4 to a maximum of $5.7 \mathrm{mg} / \mathrm{L}$ in Elkhorn Creek at Frankfort. Median concentrations ranged from 0.02 to $0.72 \mathrm{mg} / \mathrm{L}$; again, the concentrations were significantly higher at Elkhorn Creek than at the other six fixed stations. Concentrations of total phosphorus reported by the KDOW were slightly lower at virtually all paired stations, presumably because of differences in collection methods (as discussed in an earlier section of this report).

Median concentrations of dissolved ammonia nitrogen (table 3) ranged from 0.02 to $0.04 \mathrm{mg} / \mathrm{L}$. Concentrations in Elkhorn Creek were significantly higher than those in the North Fork Kentucky River at Jackson, the Middle Fork Kentucky River at Tallega, and the South Fork Kentucky River at Booneville; however, differences were not significant among concentrations in the Kentucky River at Lock 10, Lock 4, and Lock 2. Concentrations of total ammonia plus organic nitrogen ranged from 0.30 to $0.90 \mathrm{mg} / \mathrm{L}$, and concentrations were significantly higher in Elkhorn Creek at Frankfort than at any of the other fixed stations. Concentrations for each of these constituents reported by the KDOW are slightly lower at paired stations. Median concentrations of dissolved nitrite plus nitrate nitrogen ranged from $0.2 \mathrm{mg} / \mathrm{L}$ in the Middle Fork Kentucky River at Tallega to $3.5 \mathrm{mg} / \mathrm{L}$ in Elkhorn Creek at Frankfort. The maximum concentration of total nitrite plus nitrate $(13.0 \mathrm{mg} / \mathrm{L})$ during the period of this study occurred in South Elkhorn Creek near Midway, according to data collected by KDOW. Concentrations of dissolved nitrite plus nitrate in Elkhorn Creek at Frankfort were significantly higher than at any of the other stations. Concentrations in the Kentucky River at Lock 2 were not significantly different from those at Lock 4, but they were higher than those at all the other fixed stations except Elkhorn Creek at Frankfort.

Nutrient concentrations varied little at most of the fixed stations among years for the duration of the study. Concentrations of total phosphorus and nitrogen (fig. 9), as well as concentrations of the other nutrient forms, were similar during 1987-90 in the Kentucky River at Lock 2 (fig. 9) and at the other sites on the main stem of the Kentucky River (data not shown in fig. 9). At Elkhorn Creek (fig. 9), however, concentrations of total phosphorus and total nitrogen appeared to be higher in 1987 than in the other years.

\section{Estimation of nutrient loads and yields}

Transport estimates, expressed as mean annual loads, for dissolved orthophosphorus (table 4) ranged from 236 tons in Elkhorn Creek at Frankfort to 618 tons in the Kentucky River at Lock 2. Transport estimates for total phosphorus at the seven fixed stations were fairly low in the upper end of the basin, ranging from 32.6 tons in the Middle Fork Kentucky River at Tallega to 94.2 tons in the North Fork Kentucky River at Jackson (table 4). Loads were an order of magnitude higher in the Kentucky River main stem, where mean 


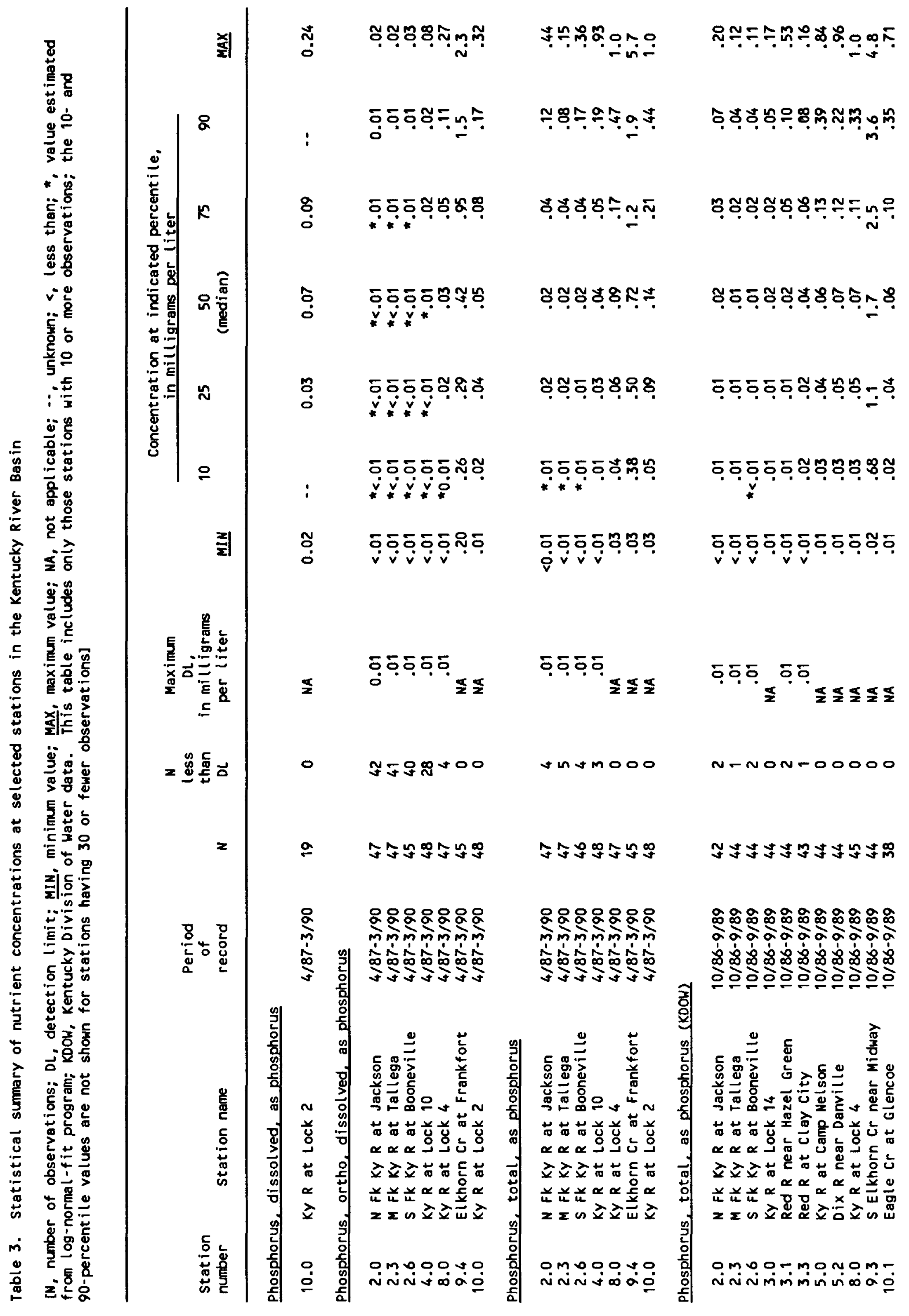




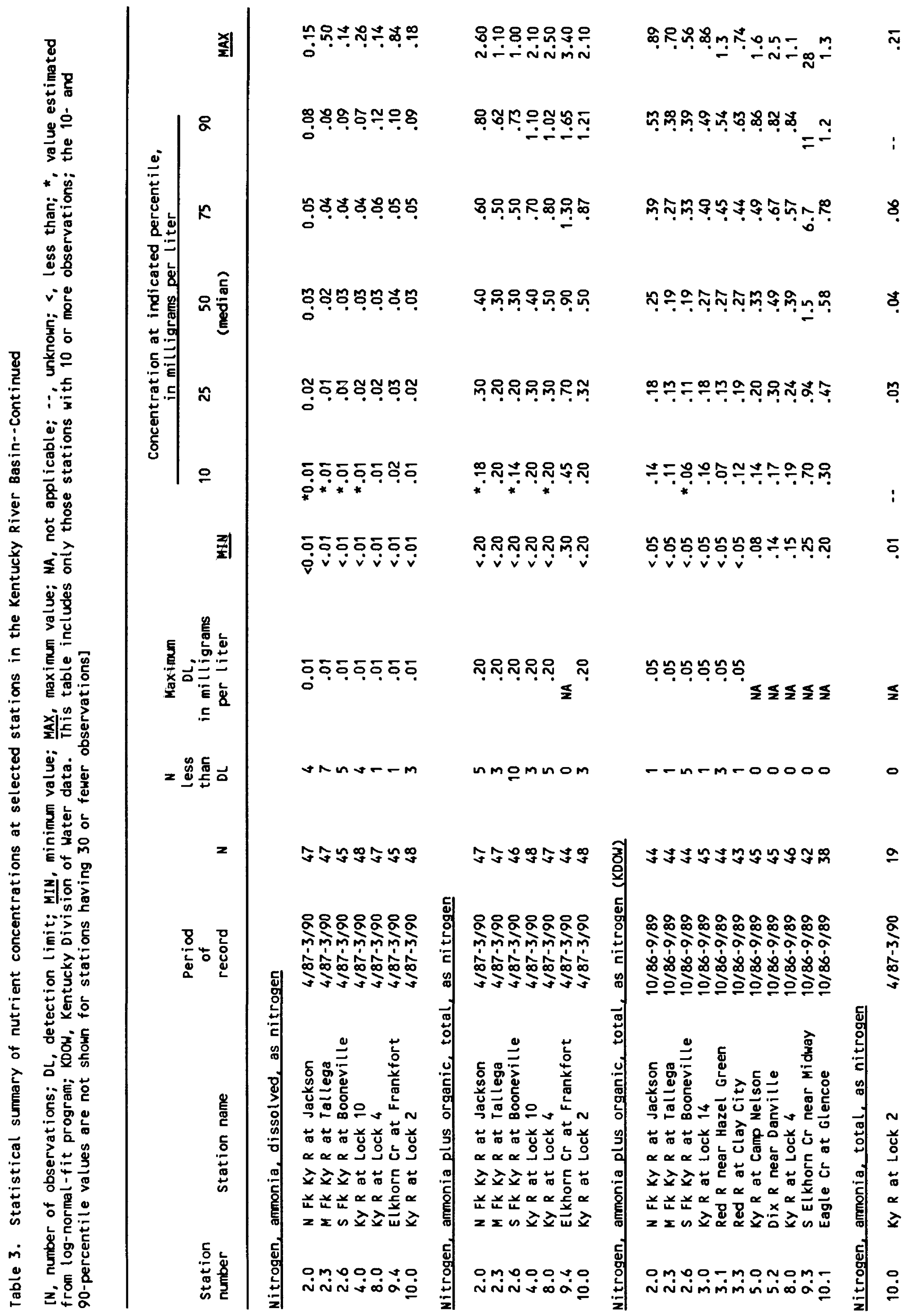




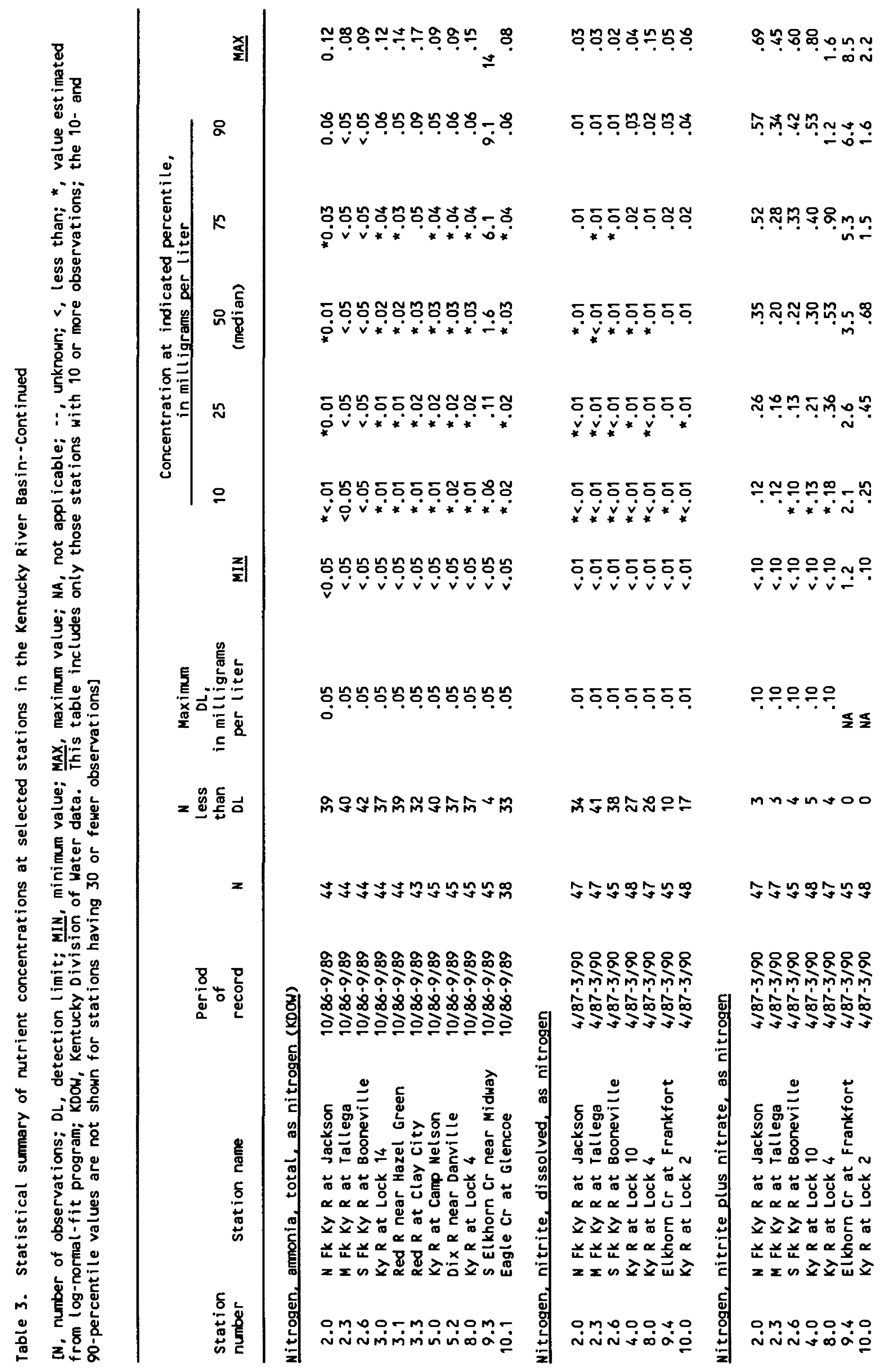




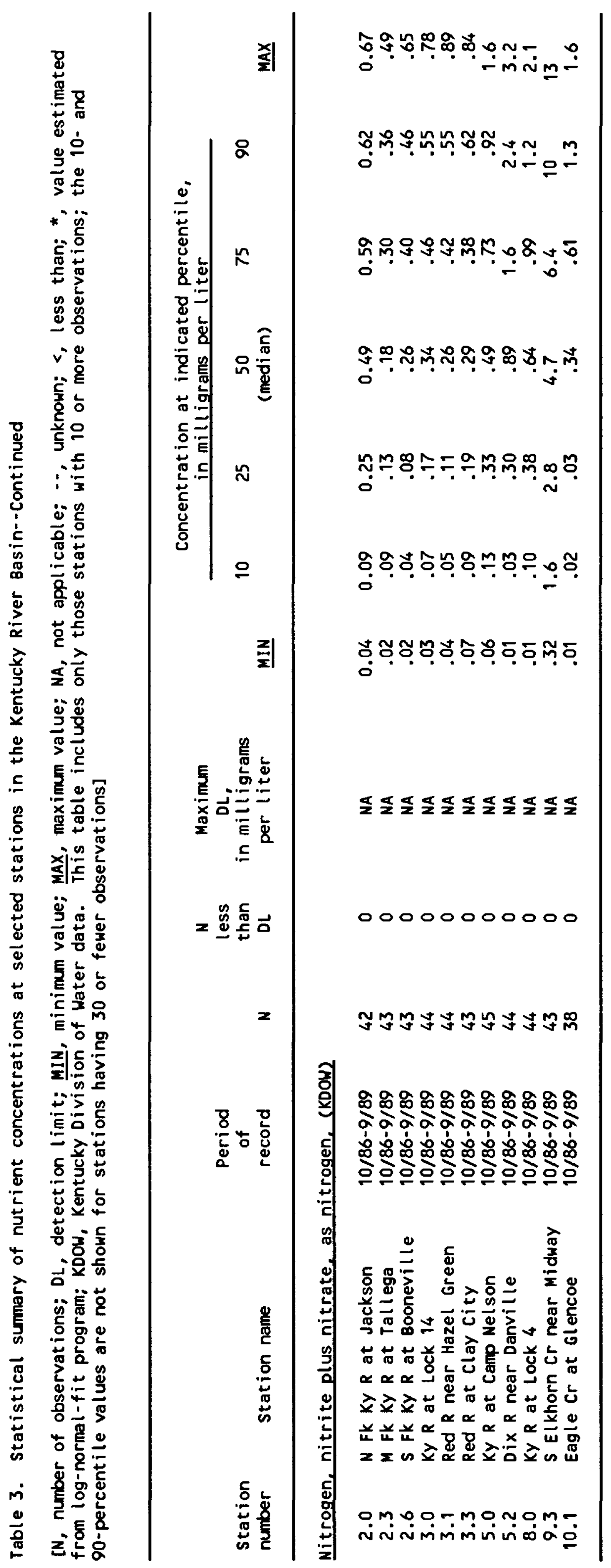



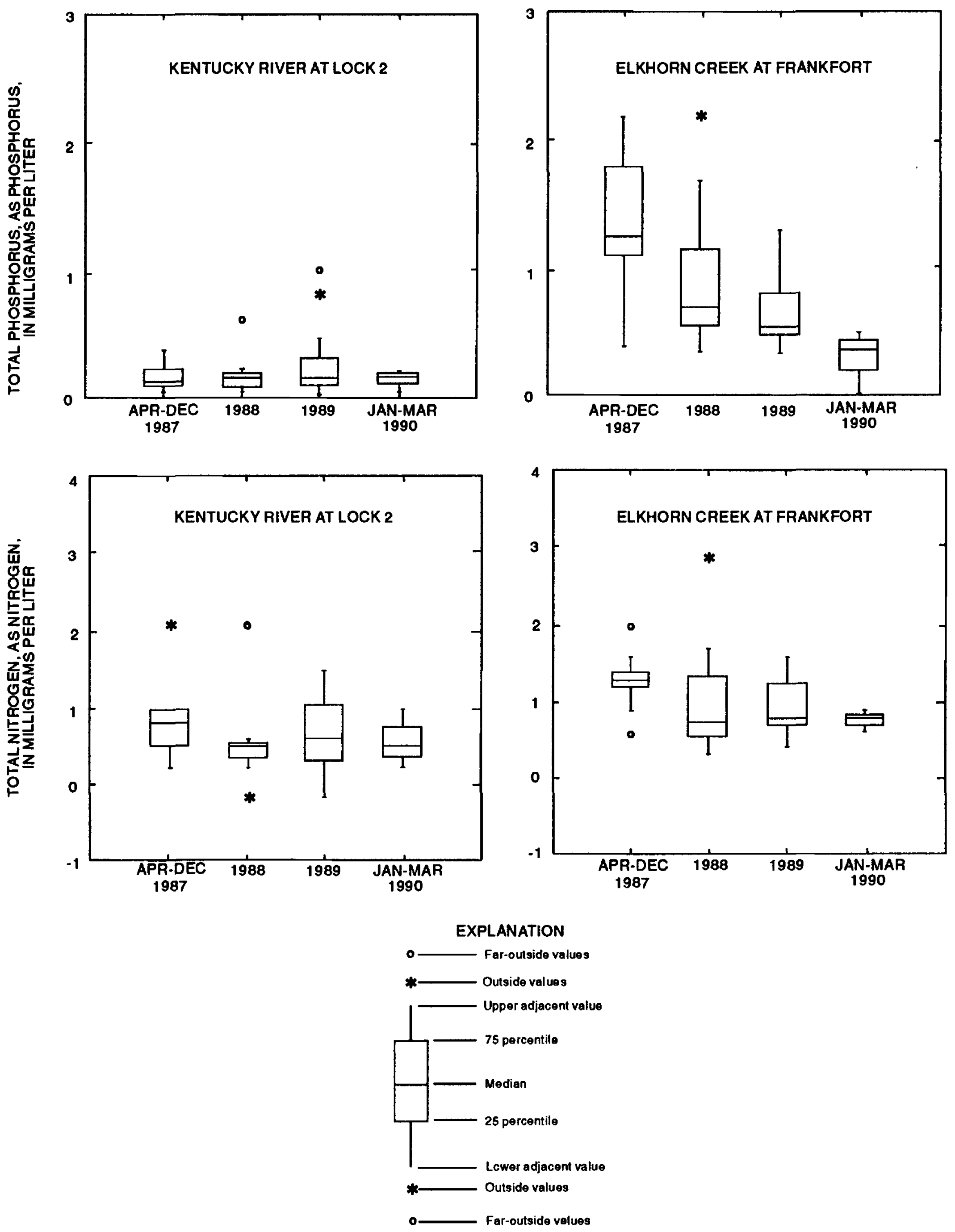

Flgure 9. Annual summary of total phosphorus and total nitrogen concentrations in the Kentucky River at Lock 2 and in Elkhorn Creek at Frankfort, Ky., April 1987-March 1990. 


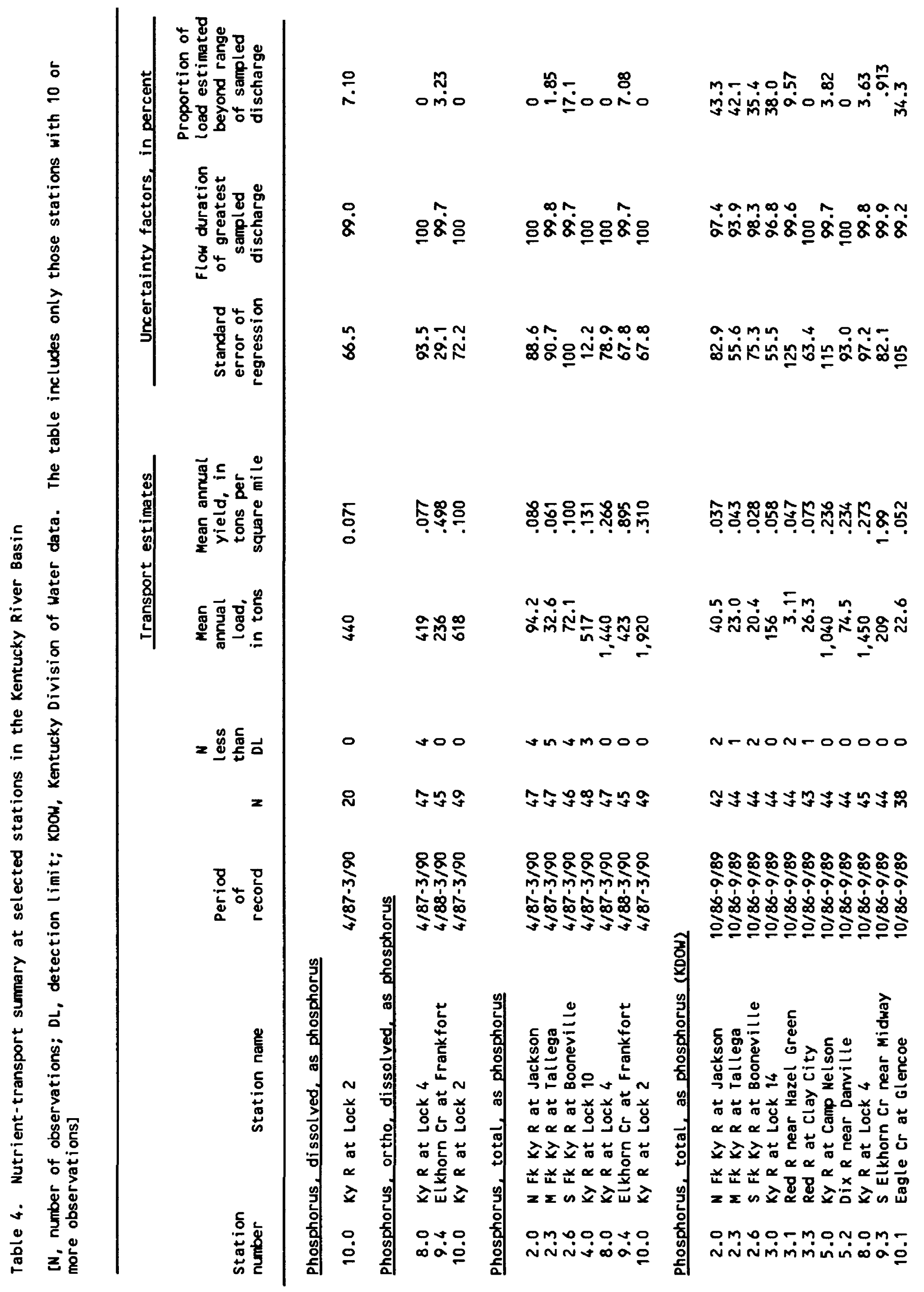




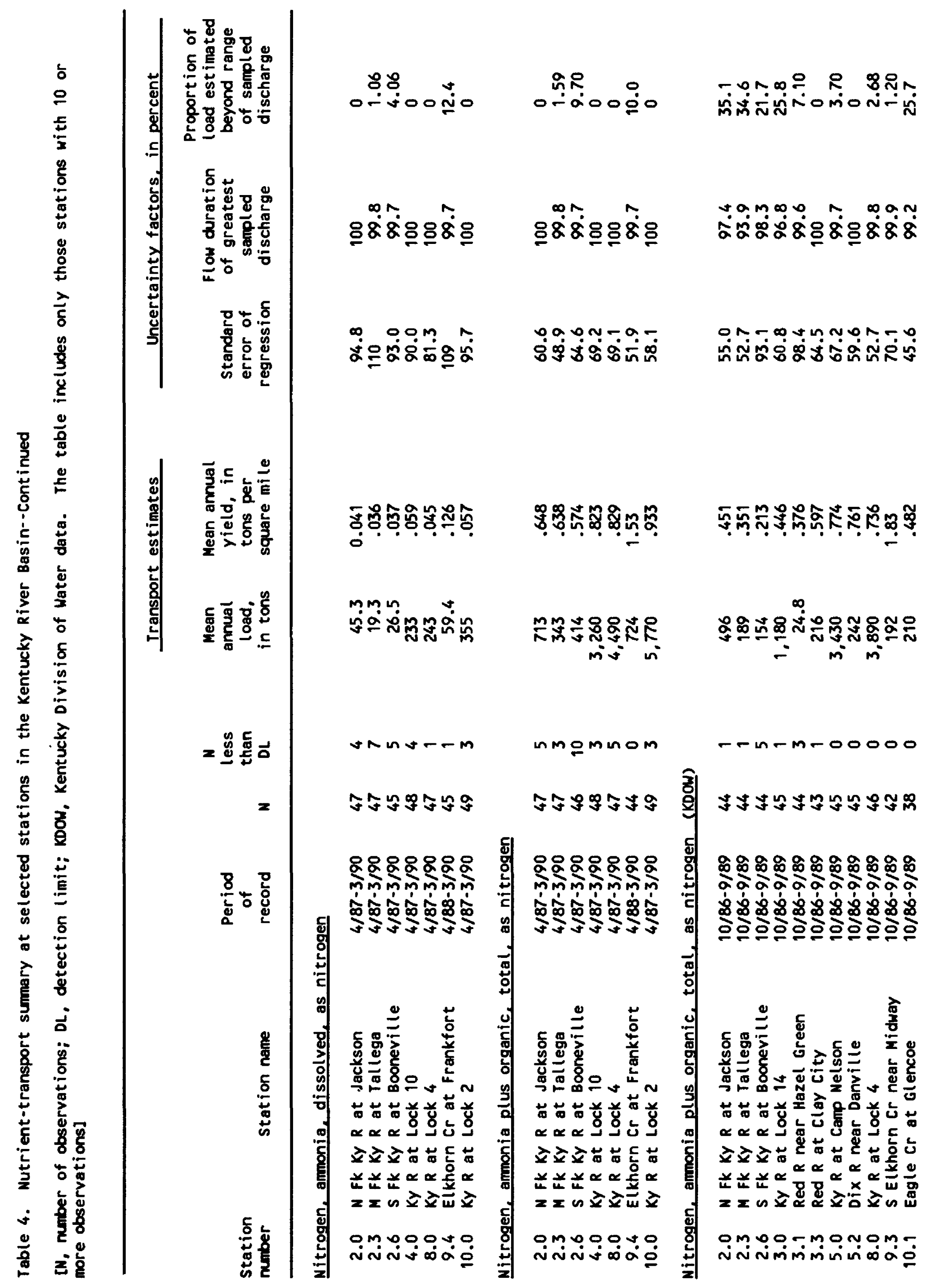




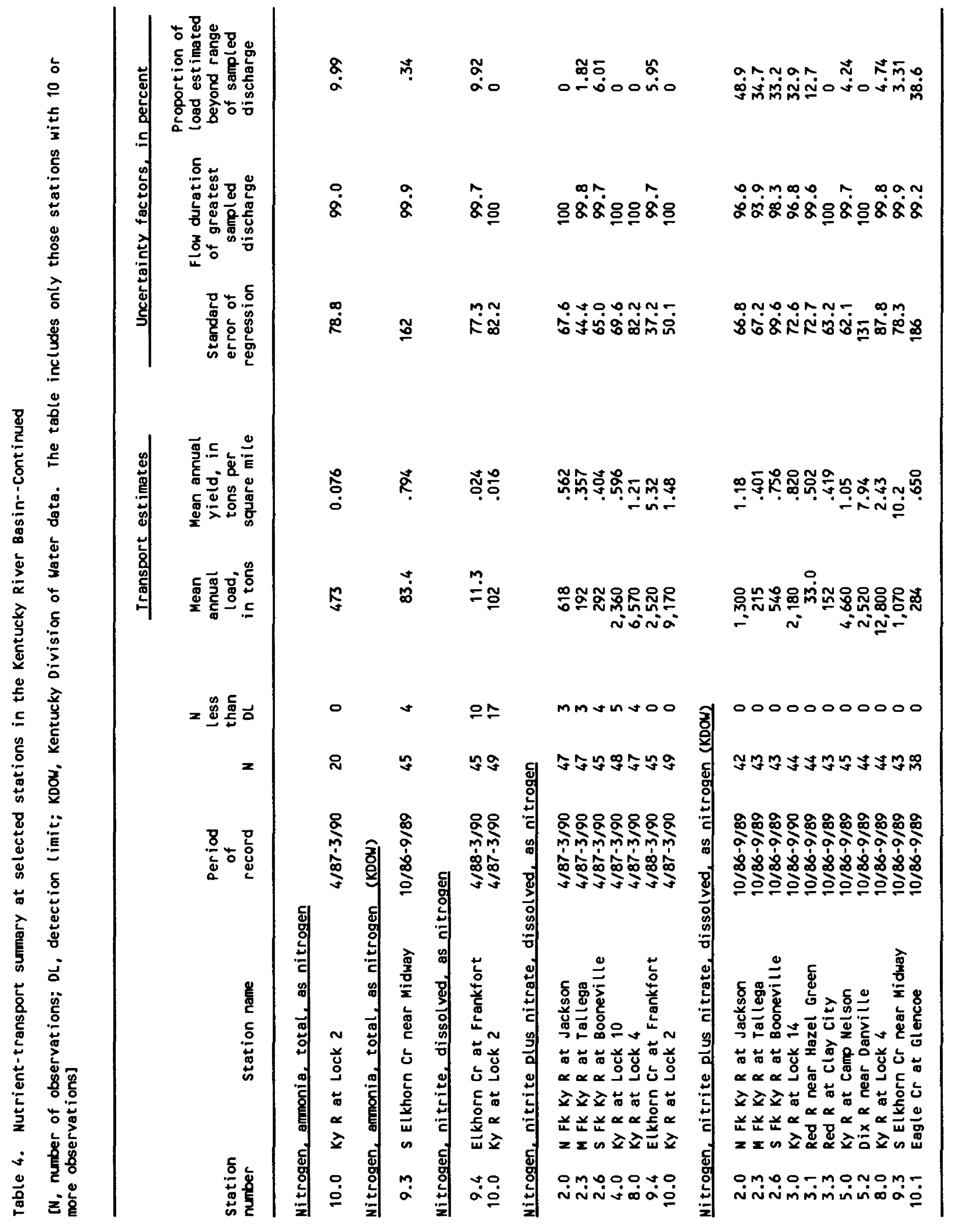


annual loads for total phosphorus were 1,440 tons at Lock 4 and 1,920 tons at Lock 2. Total phosphorus loads at the kDOW stations were lower in the upstream end of the basin, presumably because of differences in samplecollection methods and less frequent KDOW sampling during high flow.

Mean annual loads of dissolved ammonia nitrogen (table 4) were lowest in the Middle Fork Kentucky River at Tallega (19.3 tons) and highest in the Kentucky River at Lock 2 (355 tons). Annual load estimates of ammonia plus organic nitrogen ranged from 343 tons in the Middle Fork Kentucky River at Tallega to a high of 5,770 tons in the Kentucky River main stem at Lock 2 . Estimated loads reported by the KDOW from paired stations were consistently lower. Transport estimates (mean annual loads) for dissolved nitrite plus nitrate nitrogen ranged from 192 tons to 9,170 tons at the seven fixed stations. Mean annual loads of nitrite plus nitrate at KDOW paired stations were nearly double, with the exception of the Middle Fork Kentucky River at Ta1lega.

Yield estimates for phosphorus, like load estimates, are relatively low at the upstream sites in the Kentucky River but are progressively higher downstream. Mean annual yield estimates for dissolved orthophosphorus were much higher in E1khorn Creek (0.498 ton $\left./ \mathrm{mi}^{2}\right)$ than at stations on the main stem $\left(0.077\right.$ to 0.100 ton $\left./ \mathrm{mi}^{2}\right)$. Mean annual yield estimates for total phosphorus were also highest in Elkhorn Creek $\left(0.895\right.$ ton $\left./ \mathrm{mi}^{2}\right)$ compared to the other fixed sites $\left(0.061\right.$ to $\left.0.31 \mathrm{ton} / \mathrm{mi}^{2}\right)$. Yield estimates of total phosphorus reported by the KDOW were lower than NAWQA estimates at paired stations; however, data collected by KDOW indicate that the highest yield in the Kentucky River Basin for total phosphorus was at South Elkhorn Creek near Midway (1.99 ton/mi ${ }^{2}$ ).

Mean annual yields of dissolved ammonia were lowest in the Middle Fork Kentucky River at Tallega $\left(0.036 \mathrm{ton} / \mathrm{mi}^{2}\right)$ and highest in Elkhorn Creek at Frankfort $\left(0.126\right.$ ton $\left./ \mathrm{mi}^{2}\right)$. Mean annual yield estimates for ammonia plus organic nitrogen ranged from 0.574 to 1.53 ton $/ \mathrm{mi}^{2}$ at the NAWQA fixed stations and from 0.213 to 0.736 ton $/ \mathrm{mi}^{2}$ at $\mathrm{KDOW}$ paired stations. Mean annual yields of nitrite plus nitrate nitrogen were again lowest in the Middle Fork Kentucky River at Tallega $\left(0.357\right.$ ton $\left./ \mathrm{mi}^{2}\right)$ and highest in Elkhorn Creek at Frankfort (5.32 ton $\left./ \mathrm{mi}^{2}\right)$. A similar pattern of yield estimates is seen in KDOW data, but yields were higher at KDOW paired stations.

Relation of nutrients to discharge, other constituents, season, and atmospheric deposition

The concentration and distribution of nutrients in the Kentucky River Basin is related to stream discharge, other water-quality constituents, season, and atmospheric deposition.

Discharge and other constituents.--No significant correlations between nutrient concentrations and discharge were found at any of the fixed stations, with the exception of Elkhorn Creek at Frankfort, where a significant negative correlation ( $r=-0.937$ ) between discharge and orthophosphate was found. However, patterns were found between some forms of nutrients and discharge. High concentrations of phosphorus occurred at high discharges in the North 
Fork of the Kentucky River at Jackson (fig. 10) and at the other fixed stations, with the exception of E1khorn Creek. In the Kentucky River at Lock 2, concentrations of total nitrogen appeared to be higher at low and high discharges than at intermediate discharges (fig. 11).

One approach to an analysis of nutrients in the Kentucky River Basin is to examine the relation between flow duration and nutrient concentrations. The flow-duration curve (fig. 5 ) is a method of showing the percentage of time when specified discharges are equaled or exceeded in a selected period of time (Searcy, 1969). When total phosphorus was plotted along the flow-duration curve (fig. 12), similar patterns were found for four upstream sites: the highest concentrations were at high flow (flow duration less than 20 percent). Total phosphorus averaged only about $0.1 \mathrm{mg} / \mathrm{L}$ at these sites. A similar pattern was found for the Kentucky River at Lock 4 and Lock 2, but total phosphorus concentrations were much higher, possibly because of inputs from WWTP's. Total phosphorus concentrations were highest in E1khorn Creek, and the relation between total phosphorus concentrations and flow duration was different from that found for the four upstream stations. Phosphorus concentrations exceeded $1.2 \mathrm{mg} / \mathrm{L}$ at low flow (flow duration greater than 80 percent) and declined at higher flows (flow duration less than 30 percent). The pattern probably resulted from the predominance of WWTP effluent during low flow. The higher concentrations of total phosphorus at highest flows is most 1ikely attributable to overland runoff during precipitation. Bypass of untreated wastewater by WWTP's during storms also may contribute to high nutrient loadings.

No clear differences were seen between the fixed stations when ammonia nitrogen concentrations were plotted along the flow-duration curve; however, differences between stations were evident for nitrate concentrations

(fig. 13). With the exception of Elkhorn Creek, nitrate nitrogen concentrations were lowest at low flows (flow duration greater than 70 percent) and increased to a maximum at highest flows (flow duration less than 50 percent), presumably because of the increase in surface runoff. In Elkhorn Creek, the opposite was found: concentrations declined as flow increased because of the predominance of WWTP effluent during low flow. Moreover, concentrations of nitrate nitrogen were much higher in E1khorn Creek at all points on the flow-duration curve than at any of the other fixed stations. Concentrations of total nitrogen were lowest at intermediate flows (fig. 14), when dilution of point sources is maximal and surface runoff is moderate. Concentrations of total nitrogen were almost always highest in E1khorn Creek at any specified flow duration than at the other fixed stations.

At the fixed stations, concentrations of total nitrogen and dissolved nitrite plus nitrate were significantly correlated with concentrations of dissolved and total phosphorus. With few exceptions, no significant correlations were found among these nutrients and other water-quality constituents.

On the basis of data from the synoptic sites in 1987, correlations were significant between nitrite plus nitrate nitrogen and dissolved phosphorus, dissolved orthophosphorus, and total phosphorus. In 1988, dissolved ammonia nitrogen and dissolved organic carbon were significantly correlated. When 


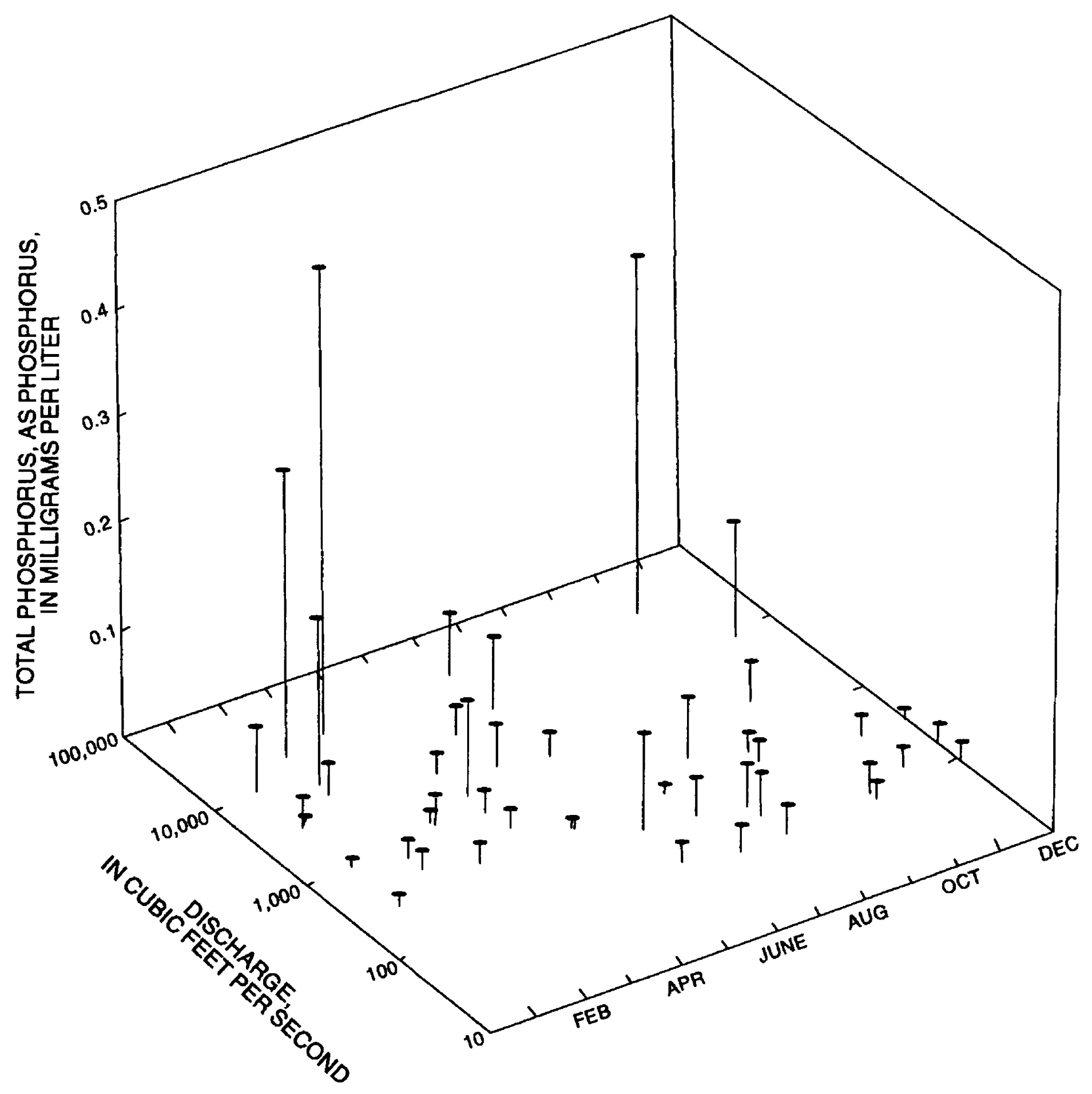

Flgure 10. Variations in mean monthly discharge and mean monthly total phosphorus concentration in the North Fork Kentucky River at Jackson, 1987-90. 


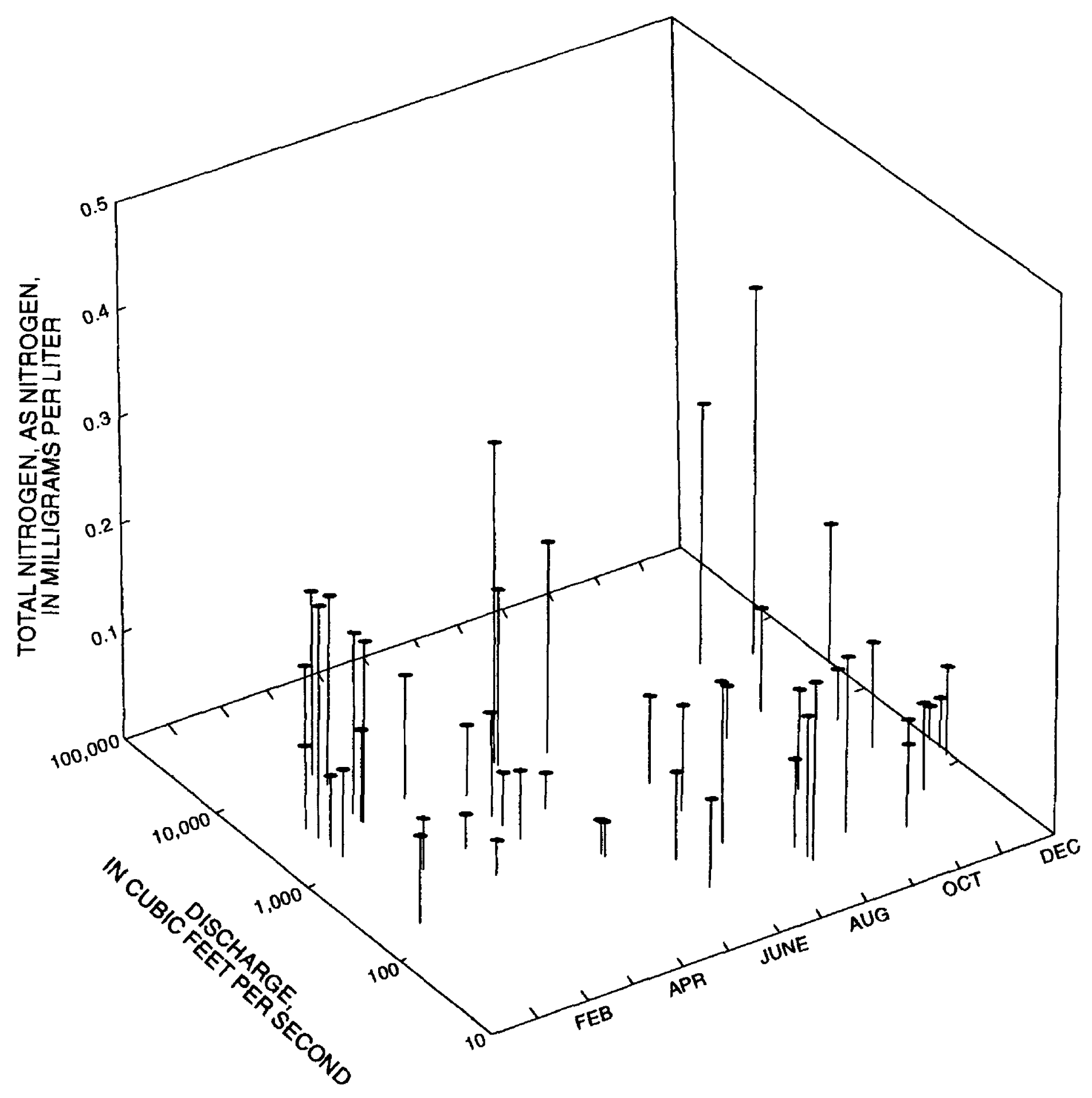

Figure 11. Variations in mean monthly discharge and mean monthly total nitrogen concentration in the Kentucky River at Lock 2, 1987-90. 

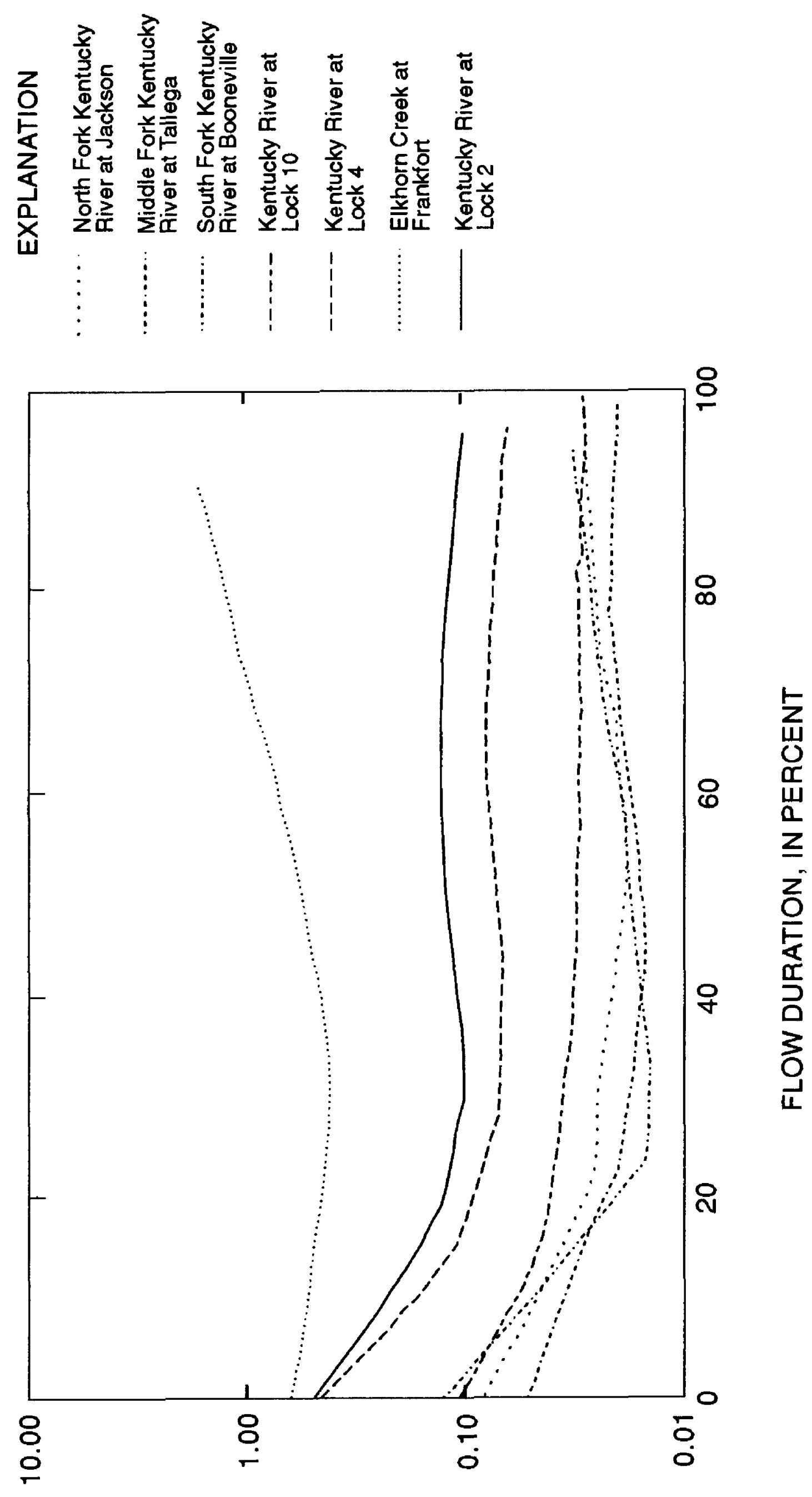

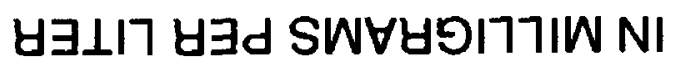

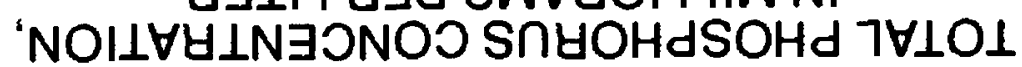



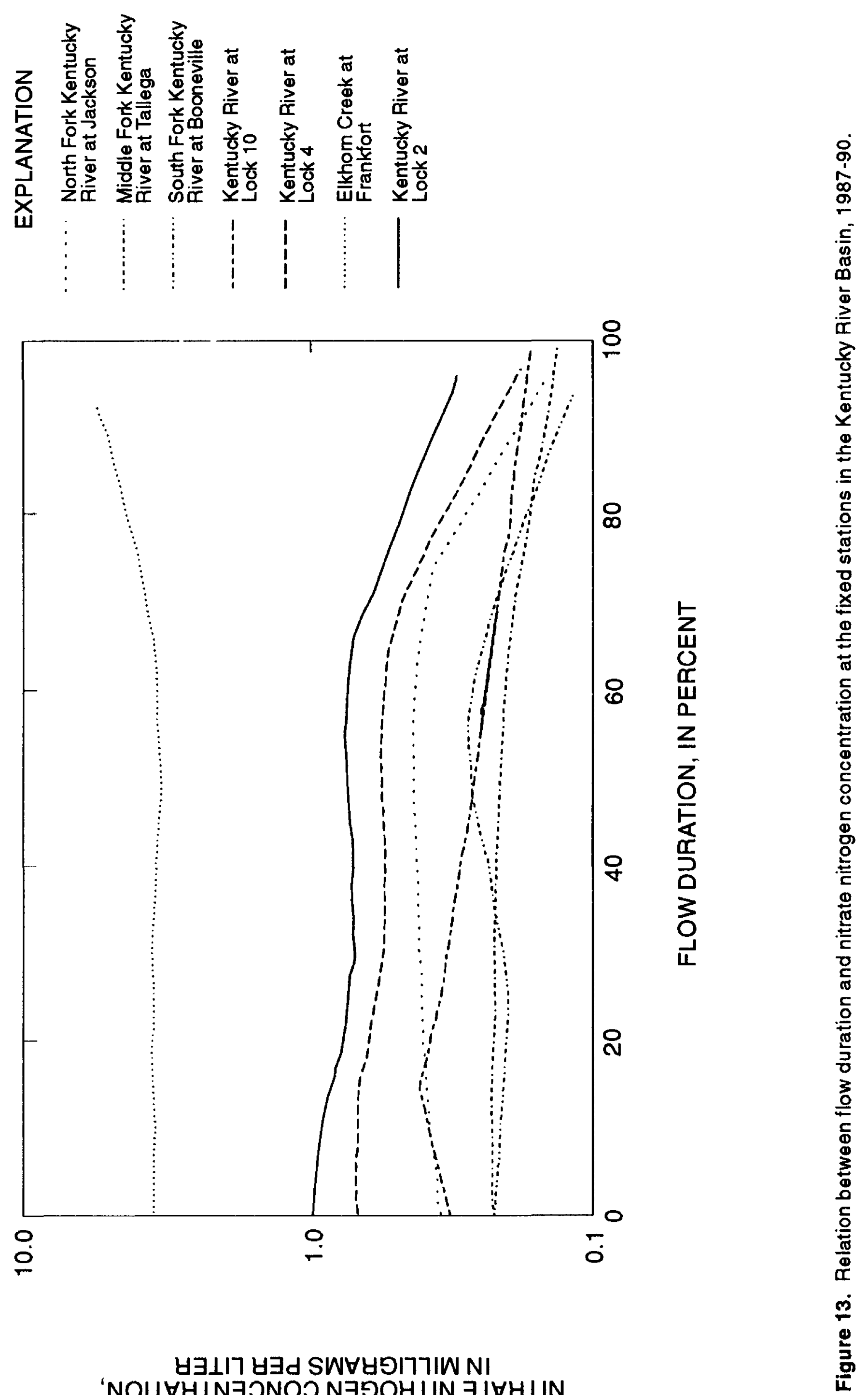

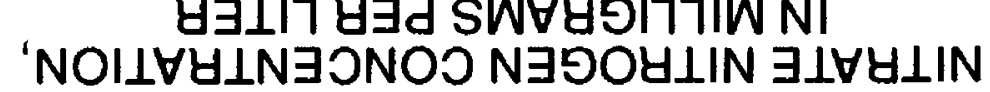



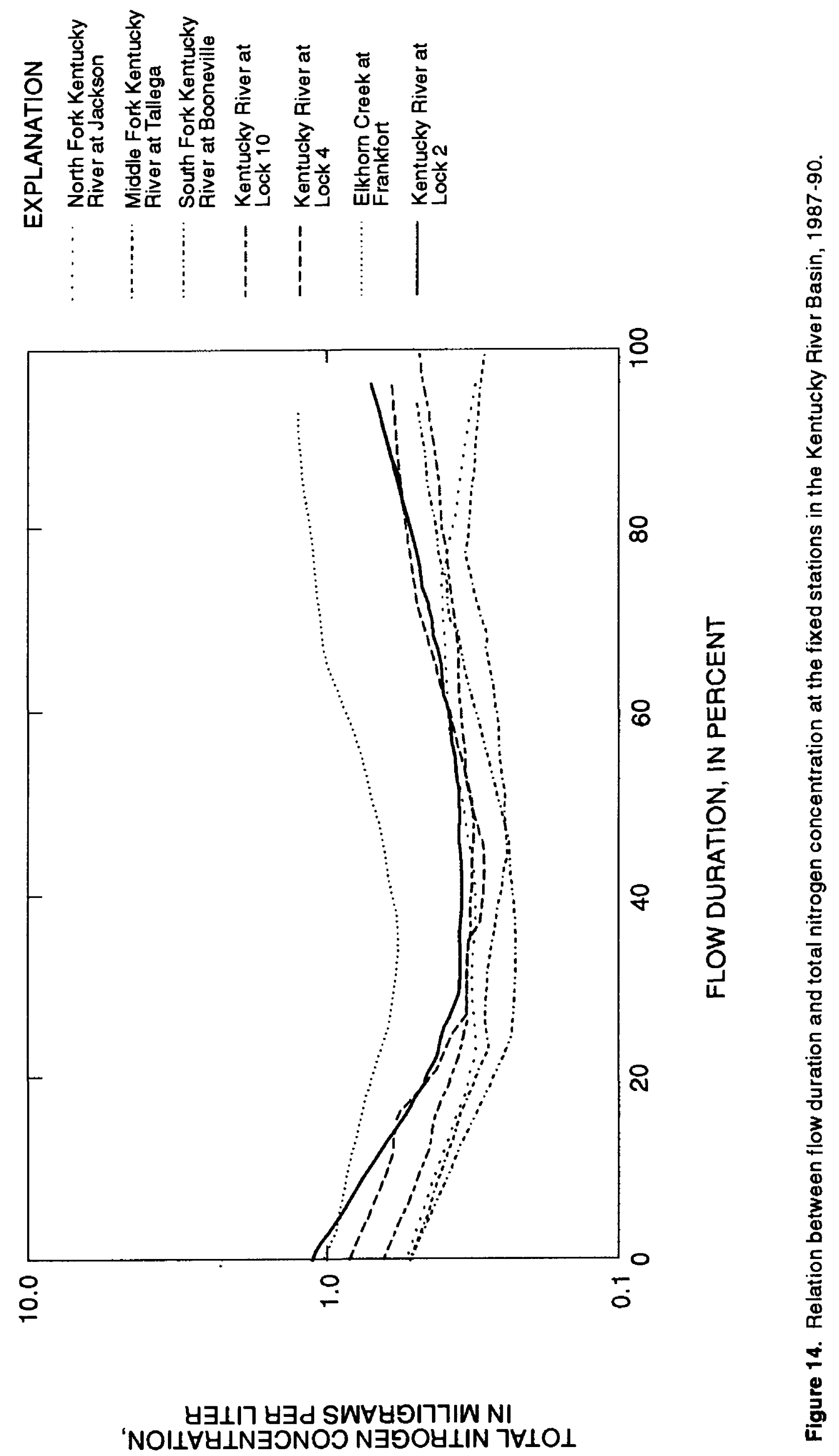
data from both water years were combined, correlations were significant among total suspended sediment, total phosphorus, and dissolved nitrite plus nitrate nitrogen.

Season.--The relation between season and total phosphorus concentrations is significant in Elkhorn Creek and in the Kentucky River at Lock 2 but not at any of the other fixed stations. In Elkhorn Creek, total phosphorus concentrations were higher in summer and fall (low flow) than in winter and spring (high flow) because of reduced dilution of WWTP sources of phosphorus. In the Kentucky River at Lock 2, total phosphorus concentrations were significantly higher in fall and winter than in spring and summer. Seasonal differences in orthophosphorus were significant for Elkhorn Creek as well as for two other fixed stations. Orthophosphorus concentrations were significantly lower in summer than in any other season at Lock 4, possibly because of uptake by algae, and were significantly higher in winter at Lock 2 than during other seasons of the year.

No significant differences in ammonia nitrogen concentrations with respect to season were found for any of the fixed stations other than Lock 4, where concentrations were significantly higher in summer. No significant differences in nitrate nitrogen or total nitrogen were attributable to season at any of the fixed sites. However, seasonal patterns were seen in nitrite plus nitrate nitrogen concentrations. At Lock 10, Lock 4, and Lock 2, nitrite plus nitrate nitrogen concentrations were lowest in spring and summer, whereas at the Middle Fork at Tallega, concentrations were highest in winter.

Atmospheric deposition.--Atmospheric deposition is an important nonpoint source of nitrogen in streams (Puckett, 1994). Estimates have been developed for the contribution of ammonia and nitrate nitrogen from precipitation in the Kentucky River Basin (L.J. Puckett, U.S. Geological Survey, written commun., 1992). These estimates are based on wet- and dry-precipitation data collected during 1984-90 at sites in Letcher, Rowan, and Washington Counties. An estimated 14,124 tons of total nitrogen are deposited in the Kentucky River Basin annually. This mass of nitrogen in the form of atmospheric deposition is equivalent to the total estimated amount of nitrogen applied as fertilizer in the Kentucky River Basin (14,046 tons).

The relative contributions of nitrogen from atmospheric deposition and fertilizers in the Kentucky River Basin differ from those in the other NAWQA pilot project study units (Wilber and Davis, 1993). In the Yakima River Basin, the total annual application of nitrogen fertilizer was approximately 19,650 tons, whereas estimated atmospheric deposition of nitrogen was 3,911 tons. In the upper Illinois River Basin, an estimated 174,920 tons of nitrogen fertilizer was applied annually, compared to 7,500 tons of nitrogen that fell as atmospheric deposition. In the Kansas River Basin, total nitrogen fertilizer applied was approximately 213,760 tons annually, whereas the estimated annual nitrogen deposition from precipitation was 25,745 tons. These comparisons indicate that dominant nitrogen sources vary among watersheds and that atmospheric deposition of nitrogen remains a factor to be considered in watershed studies (Puckett, 1994). 


\section{Subbasin-Scale Distribution}

The distribution of nutrients in subbasins throughout the Kentucky River Basin was assessed by collecting data at the synoptic sites in August 1987 and August 1988. Data characterizing the effluent water quality from individual WWTP's were summarized from Discharge Monitoring Reports required under the Kentucky Pollution Discharge Elimination System (KPDES) program. Figures presented in this section show the results from 1987. With few exceptions, which are mentioned, data for 1988 corroborate results for 1987.

\section{Relation of nutrients to point-source discharges}

In eight subbasins of the Kentucky River Basin, no WWTP discharges occurred immediately upstream from the synoptic sites sampled in 1987 and 1988 (table 5). These subbasins are in the upper part of the Kentucky River Basin along the North, Middle, and South Forks, where population density is low and the principal land use is forest. Concentrations of dissolved orthophosphorus were all at or below the detection limit, as were many of the reported concentrations of dissolved nitrite plus nitrate nitrogen. The high concentration of total nitrogen at Redlick Creek near Station Camp and of dissolved nitrite plus nitrate nitrogen in Quicksand Creek at Lunah may have been related to untreated residential wastewater effluent or partially treated residential wastewater from sources such as septic tanks. Given that the samples were collected in both years during low flow, only small contributions to instream nutrient concentrations would be expected from nonpoint sources such as agricultural runoff. Concentrations of all forms of phosphorus and nitrogen were relatively low when compared to sites in the basin receiving WWTP effluent (table 6).

The distribution of wastewater-treatment plants in the Kentucky River Basin ( $f i g .15$ ) and their instantaneous ammonia nitrogen loads (fig. 16) reflects population distribution; the largest discharges are near the municipalities of Lexington, Frankfort, Danville, Richmond, and Hazard. Analyses of nutrient concentrations in receiving streams indicate significant effects of WWTP's throughout the basin, particularly downstream from urban areas. Concentrations of total phosphorus were greater than $0.5 \mathrm{mg} / \mathrm{L}$ (fig. 17) at numerous synoptic sites in the Bluegrass and Knobs Regions in August 1987, principally downstream from the urban areas 1 isted above. Concentrations of ammonia nitrogen exceeded $0.1 \mathrm{mg} / \mathrm{L}$ at many sites in the Kentucky River Basin in August 1987 ( $f i g .18$ ) and August 1988 (data not shown in fig. 18). These include several sites in the upstream part of the basin. Concentrations of nitrite plus nitrate nitrogen (fig. 19, table 6) exceeded $10.0 \mathrm{mg} / \mathrm{L}$ at two synoptic sites: Hickman Creek near Mills (KC) ( $14 \mathrm{mg} / \mathrm{L}$ in 1987 and $25 \mathrm{mg} / \mathrm{L}$ in 1988) and Clarks Creek near Stewartsville (SE) (11 mg/L in 1987 and $16 \mathrm{mg} / \mathrm{L}$ in 1988). In August 1988 Town Branch near Lexington (RF) had a concentration of nitrite plus nitrate nitrogen of $11 \mathrm{mg} / \mathrm{L}$. Numerous sites in both years had concentrations of nitrite plus nitrate nitrogen between 1.0 and $10.0 \mathrm{mg} / \mathrm{L}$.

The percentage of instantaneous stream discharge (fig. 20) and instantaneous stream nitrogen load (fig. 21) attributable to WWTP effluent during low flow was estimated in subbasins of the Kentucky River Basin. The 


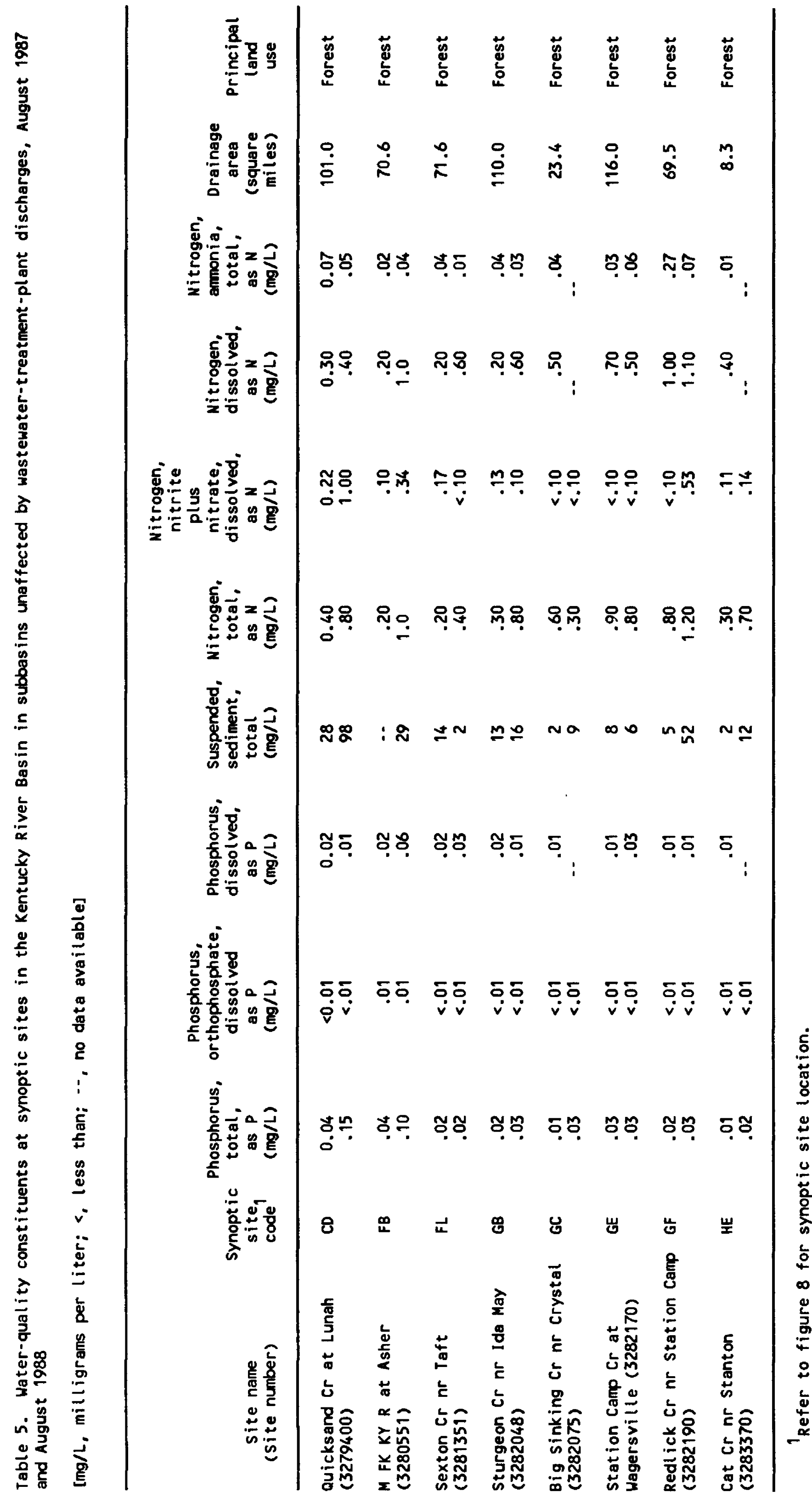




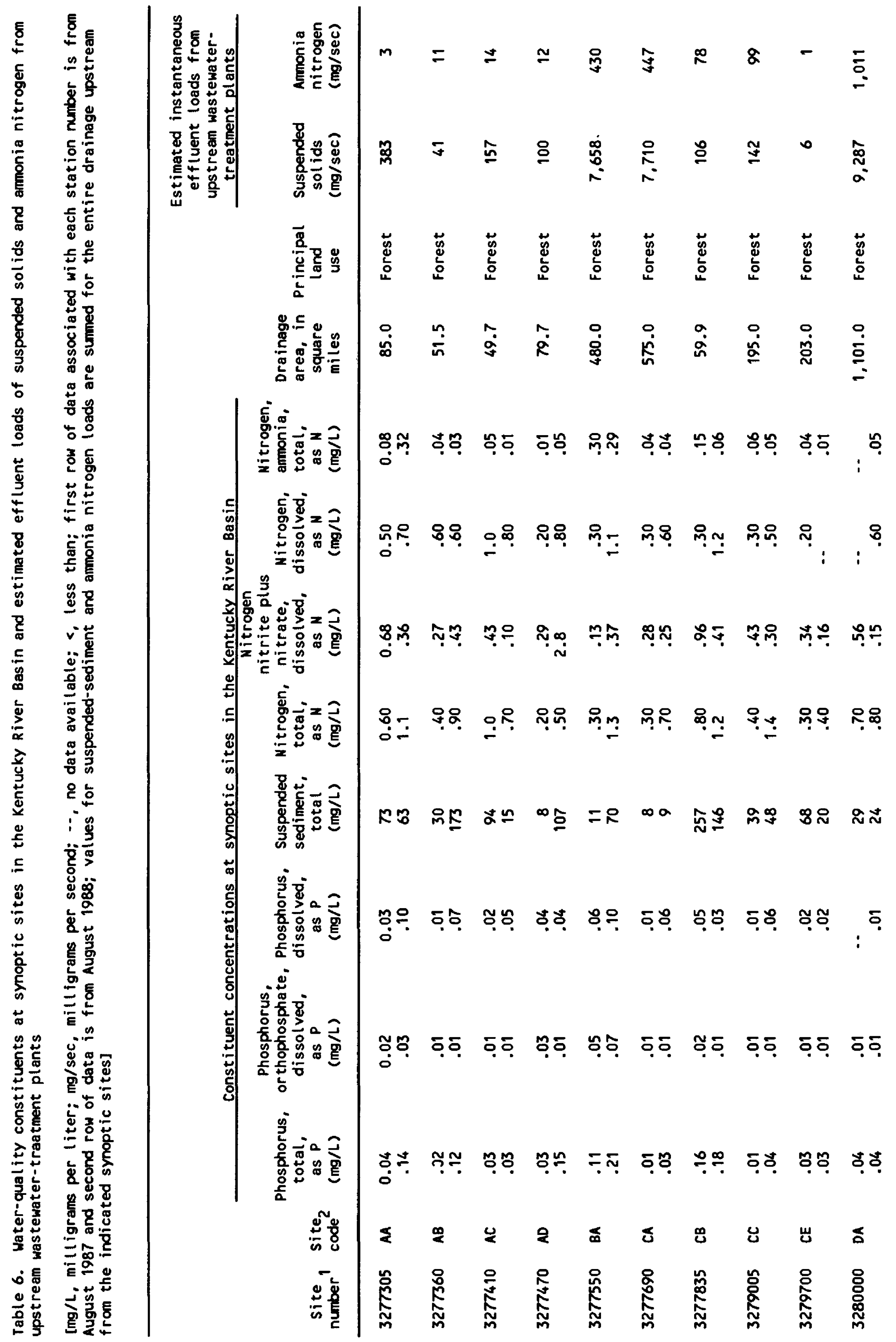




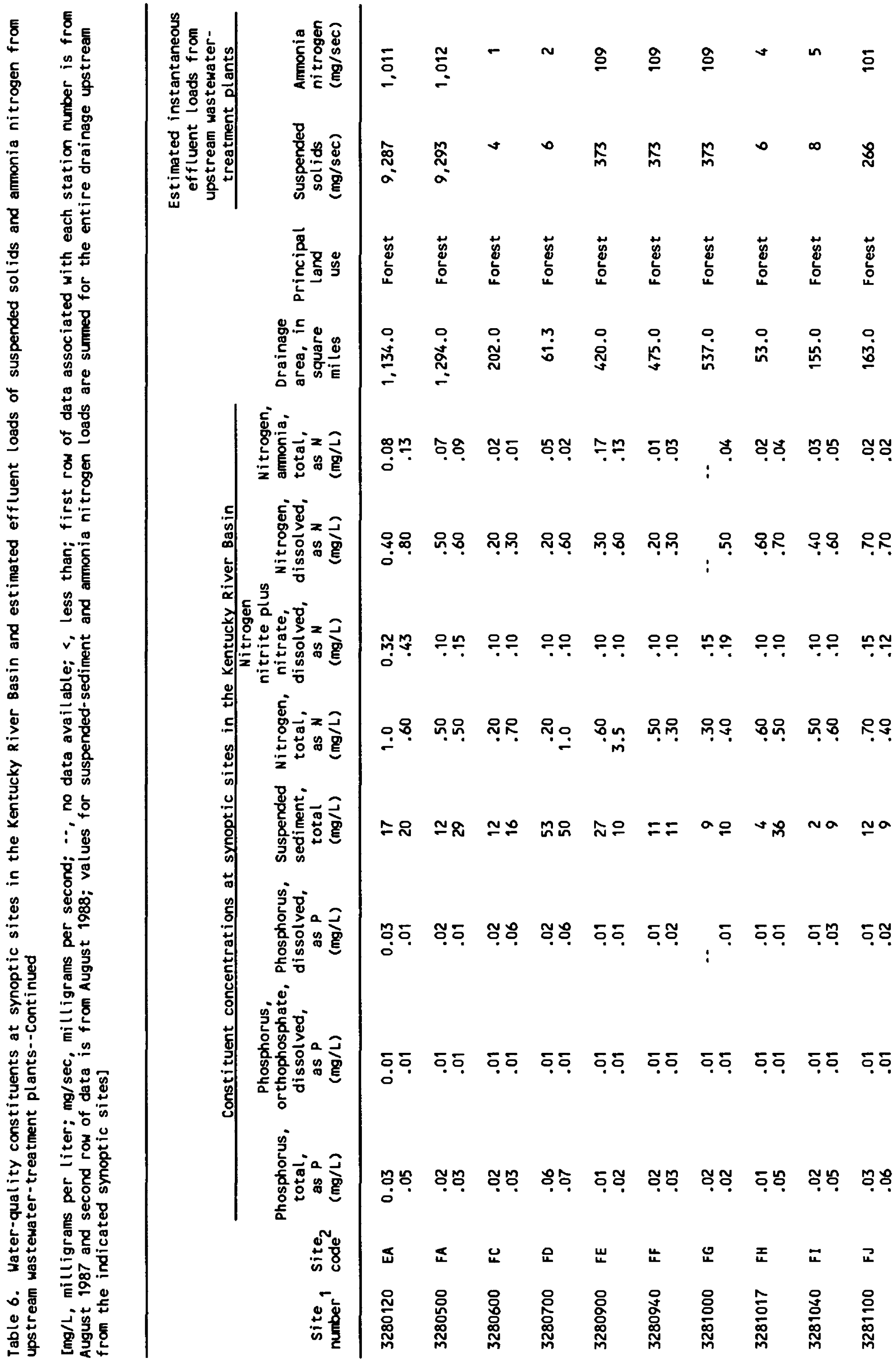




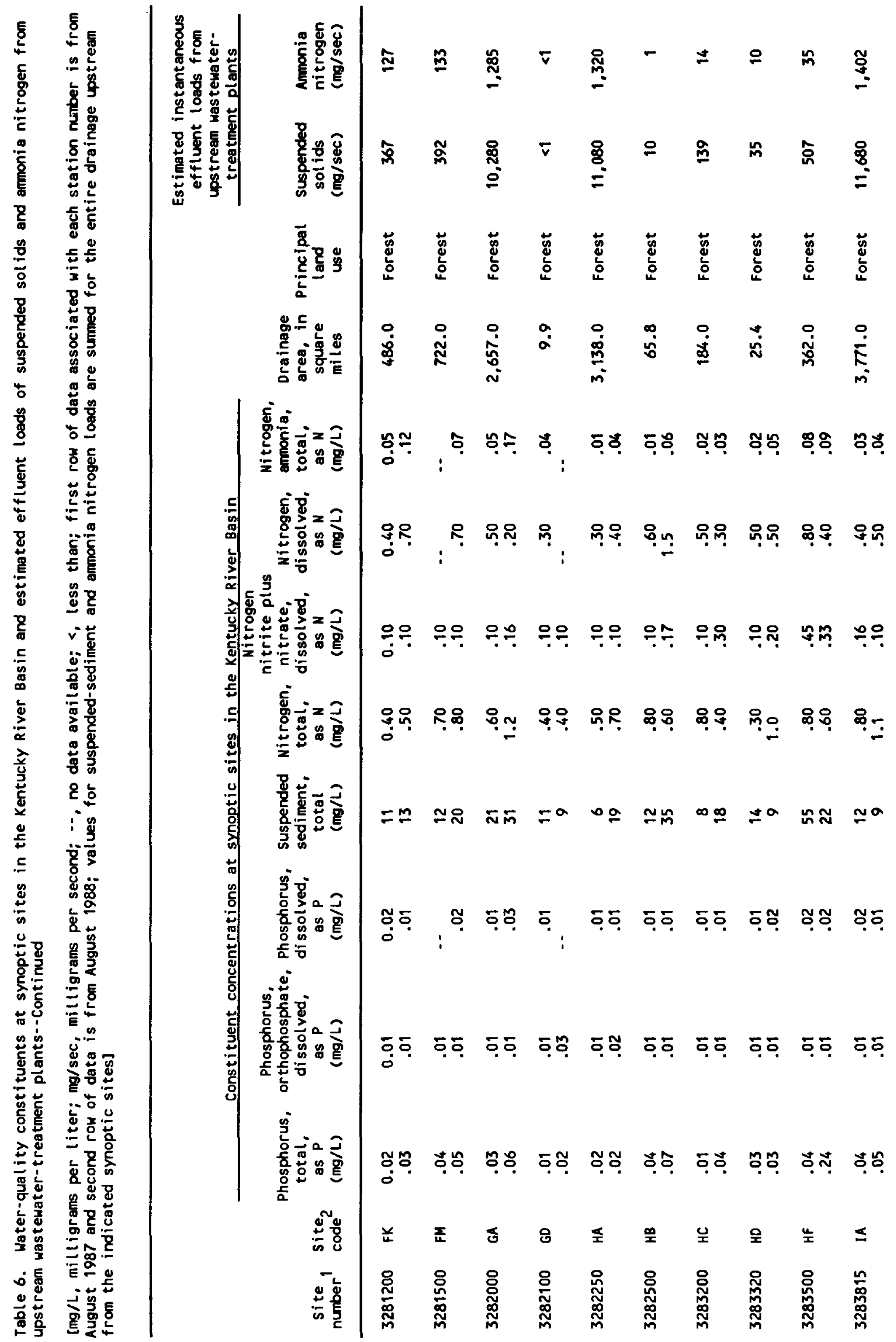




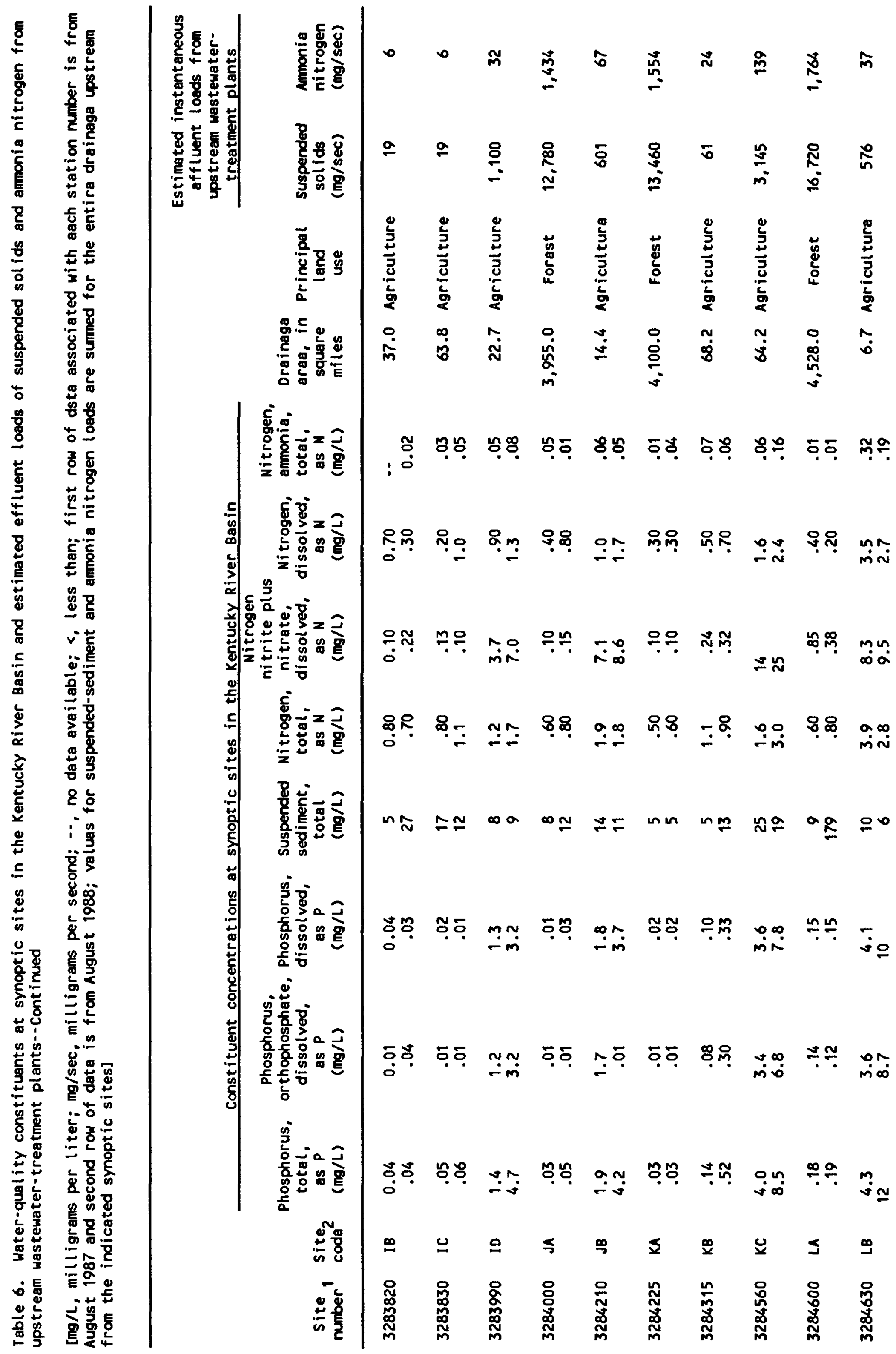




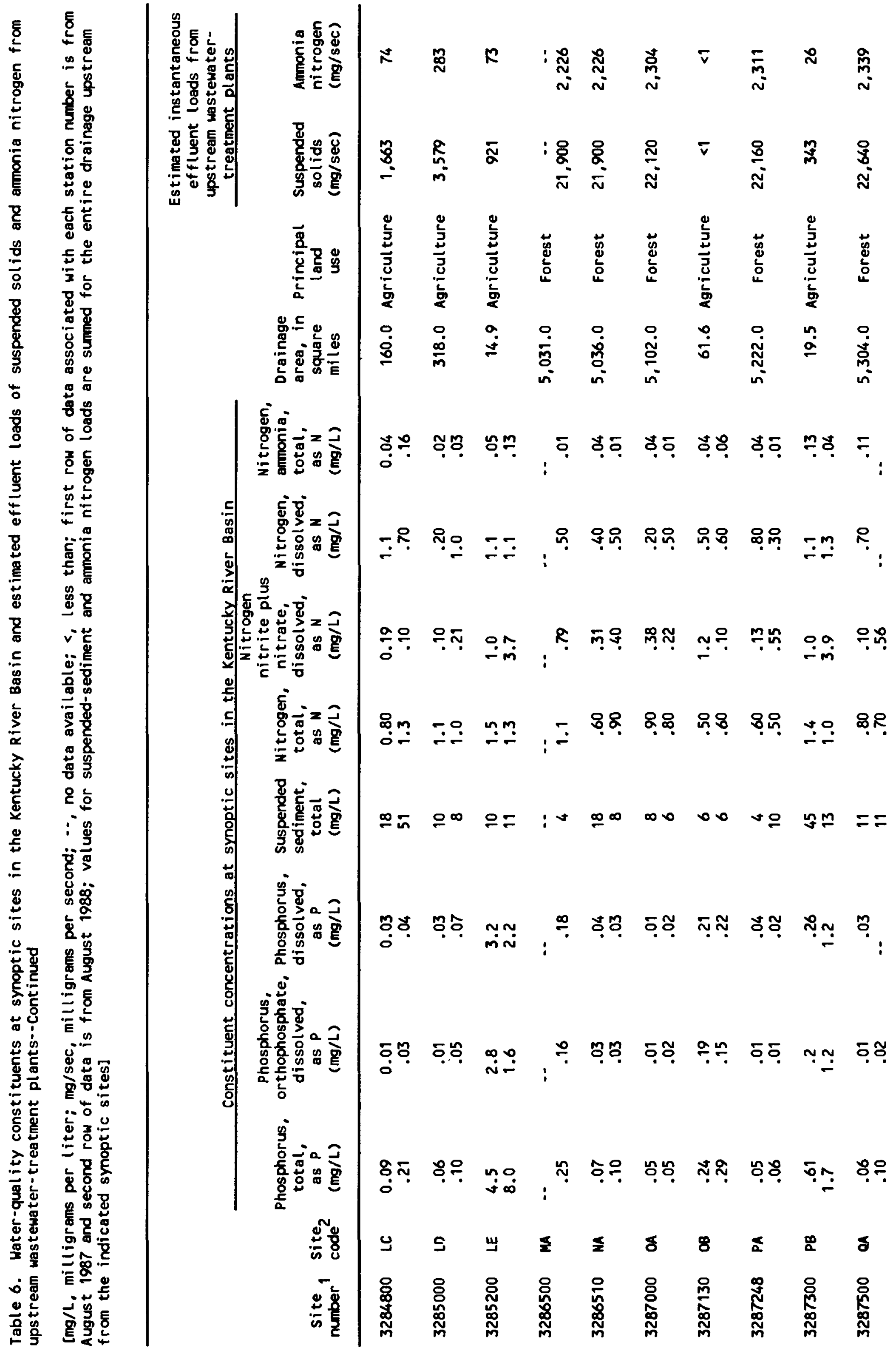




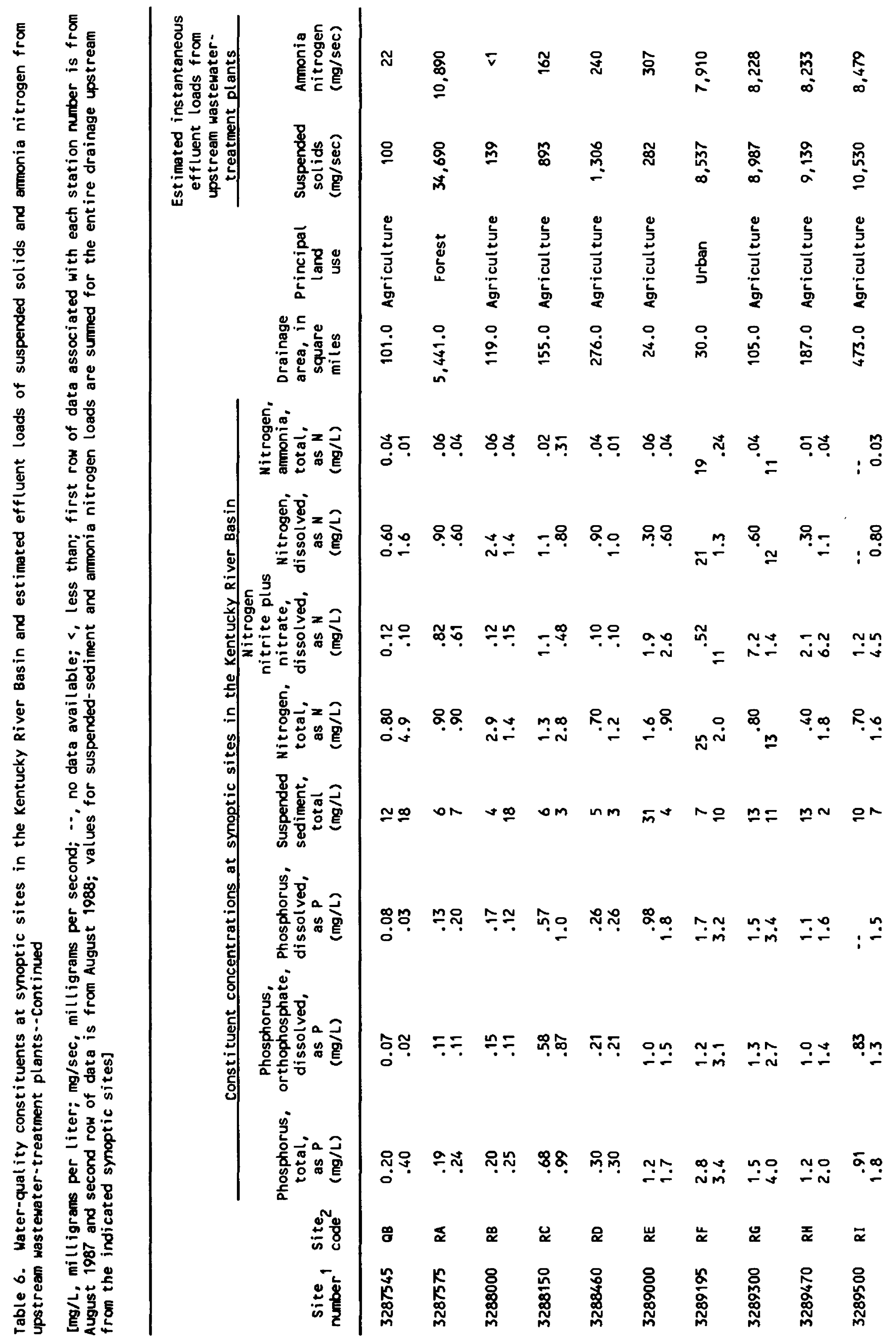




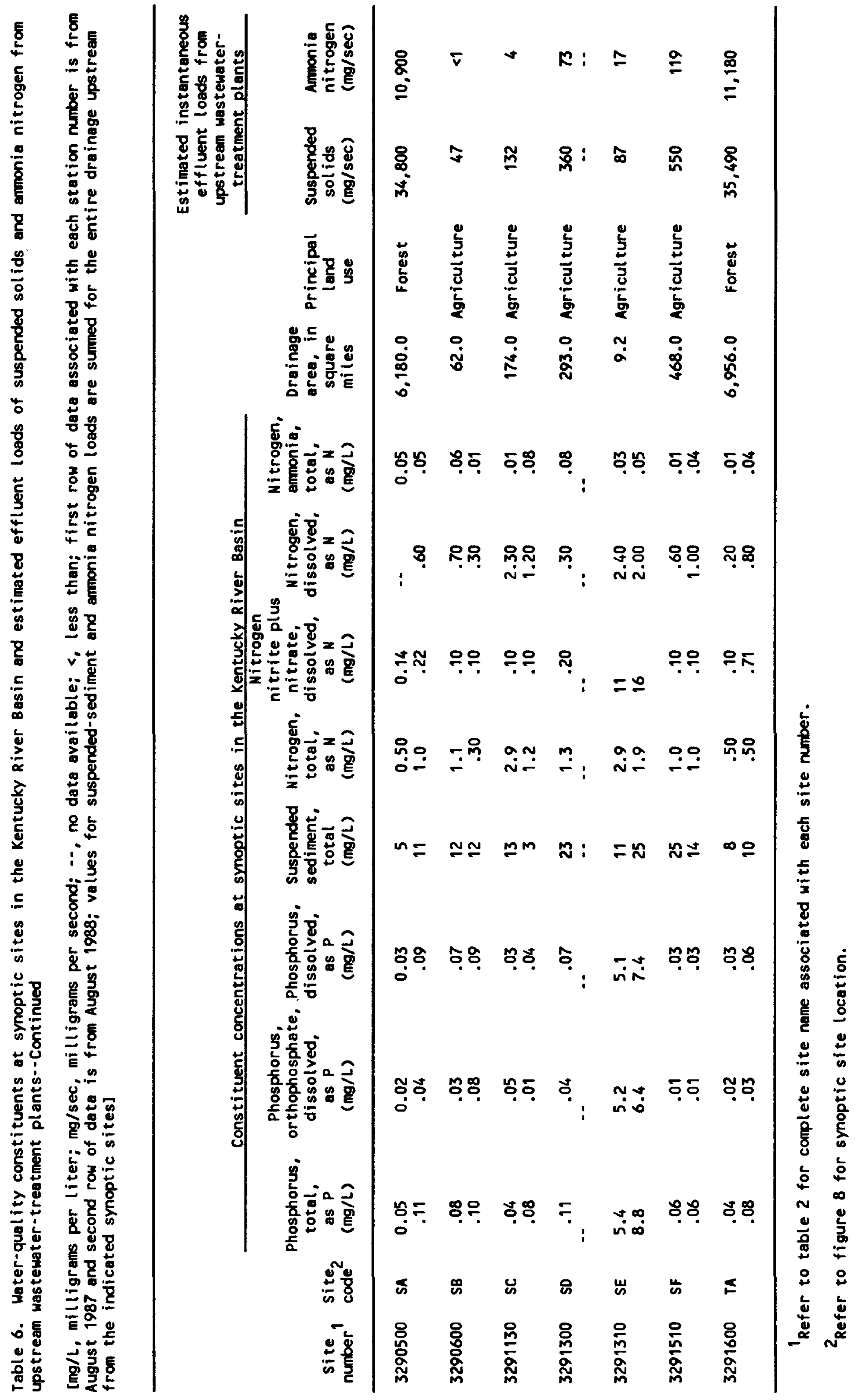




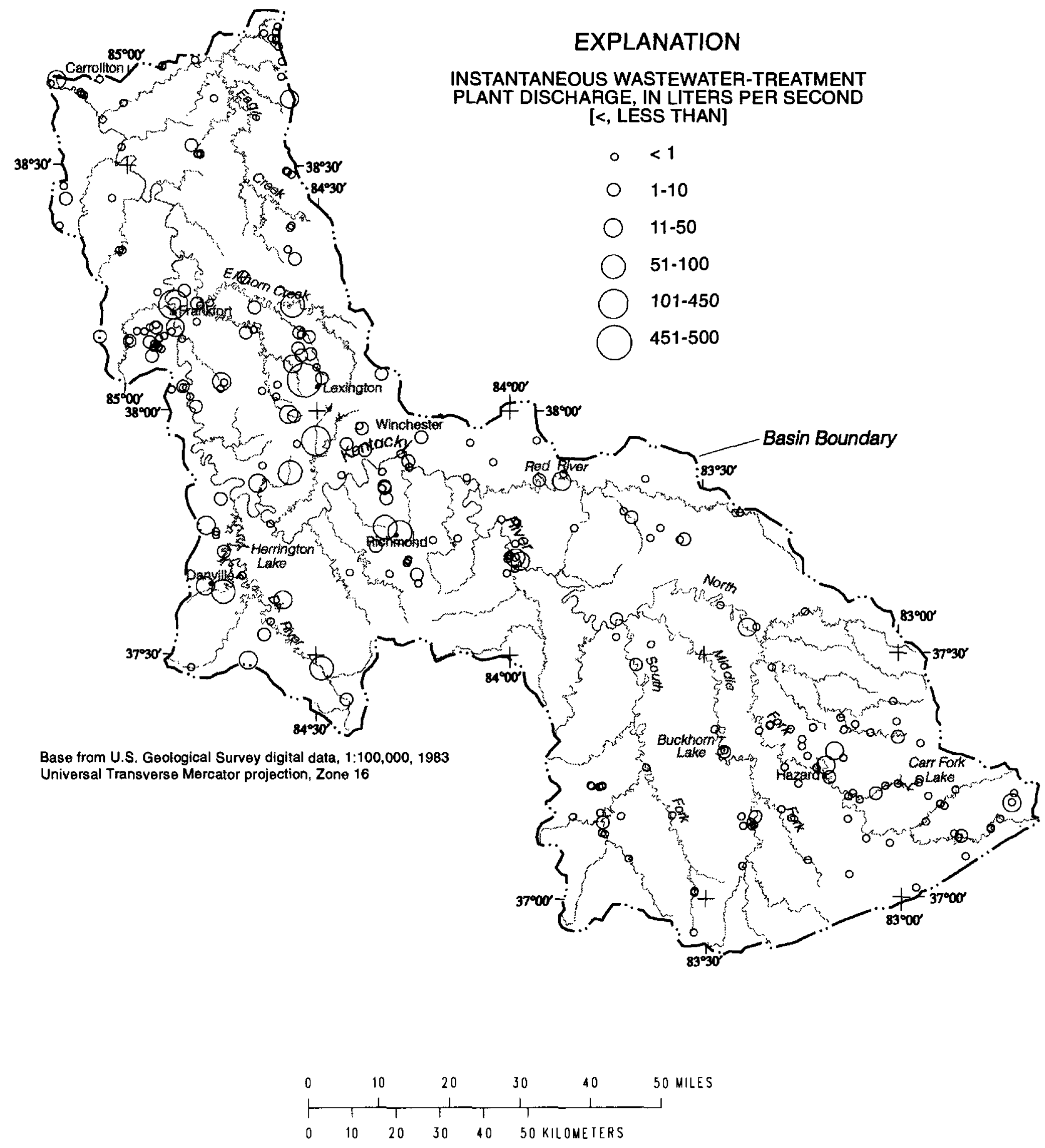

Figure 15. Instantaneous discharge from wastewater-treatment plants in the Kentucky River Basin, August, 1991. 


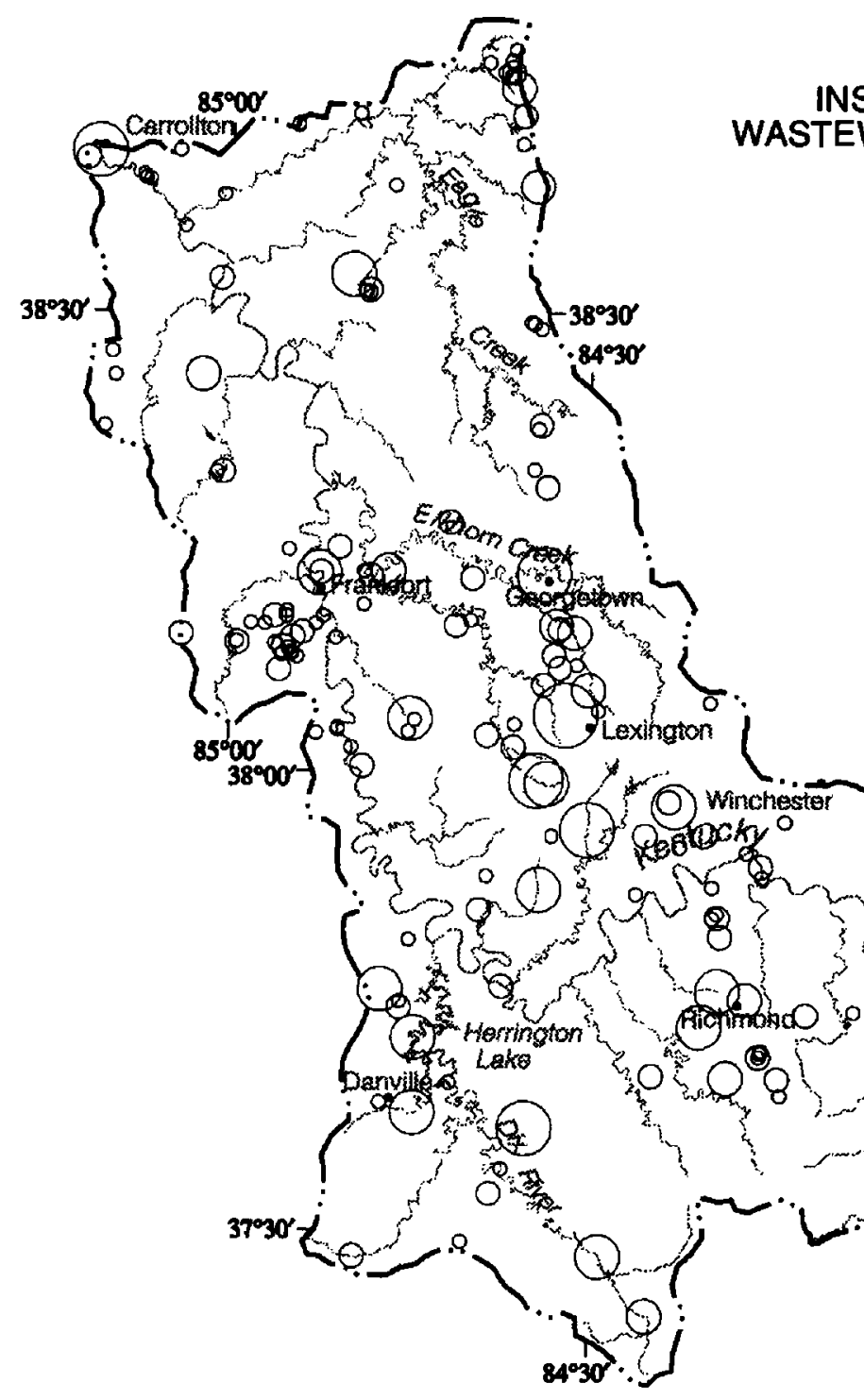

Base from U.S. Geological Survey digital data, $t: 100,000,1983$ Universal Transverse Mercator Projection, Zone 16

\section{EXPLANATION}

INSTANTANEOUS LOADS OF AMMONIA NITROGEN, FROM MENT PLANTS, IN MILLIGRAMS PER SECOND [>, GREATER THAN]
$0-1$
O $1-10$
○ $11-25$
O 26-100
(101-500
$\bigcirc>500$

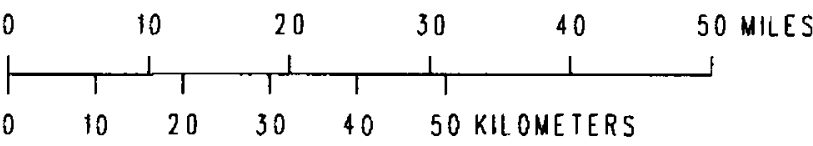

Figure 16. Instantaneous loads of ammonia nitrogen from wastewater-treatment plants in the Kentucky River Basin, August, 1991. 


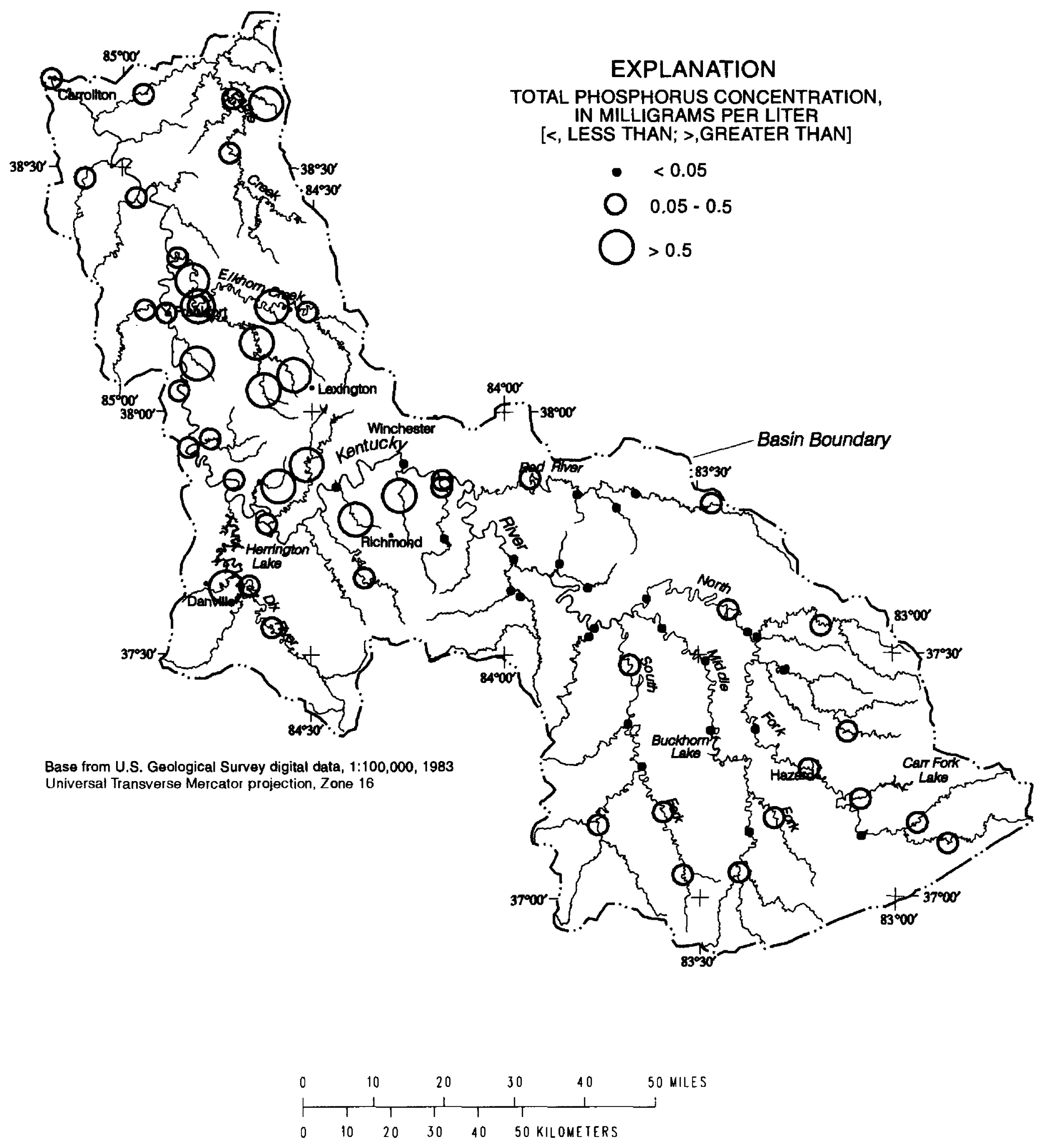

Figure 17. Concentrations of total phosphorus at synoptic sites in the Kentucky River Basin, August 8-12, 1987. 


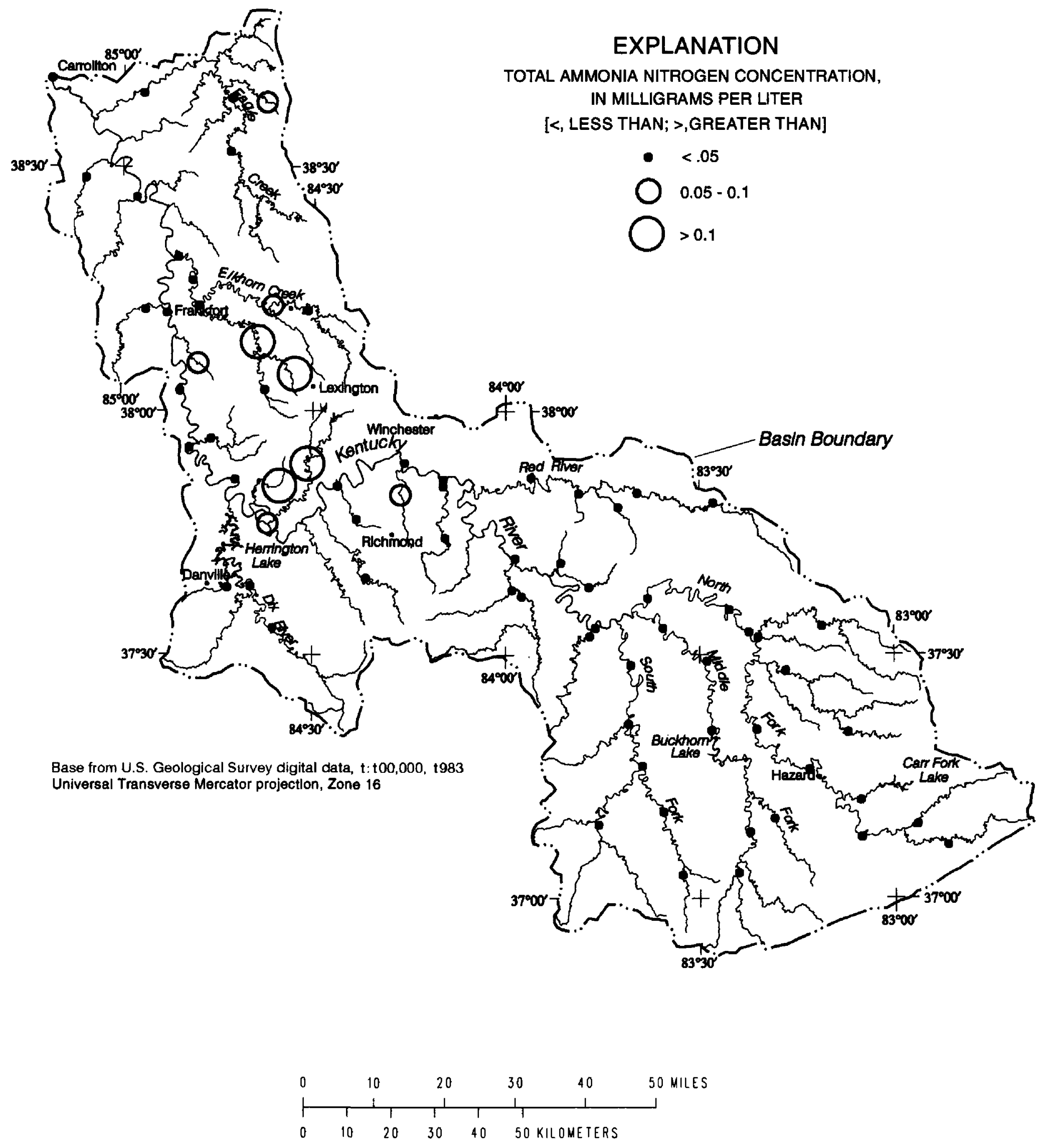

Figure 18. Concentrations of total ammonia nitrogen at synoptic sites in the Kentucky River Basin, August 8-12, 1987. 


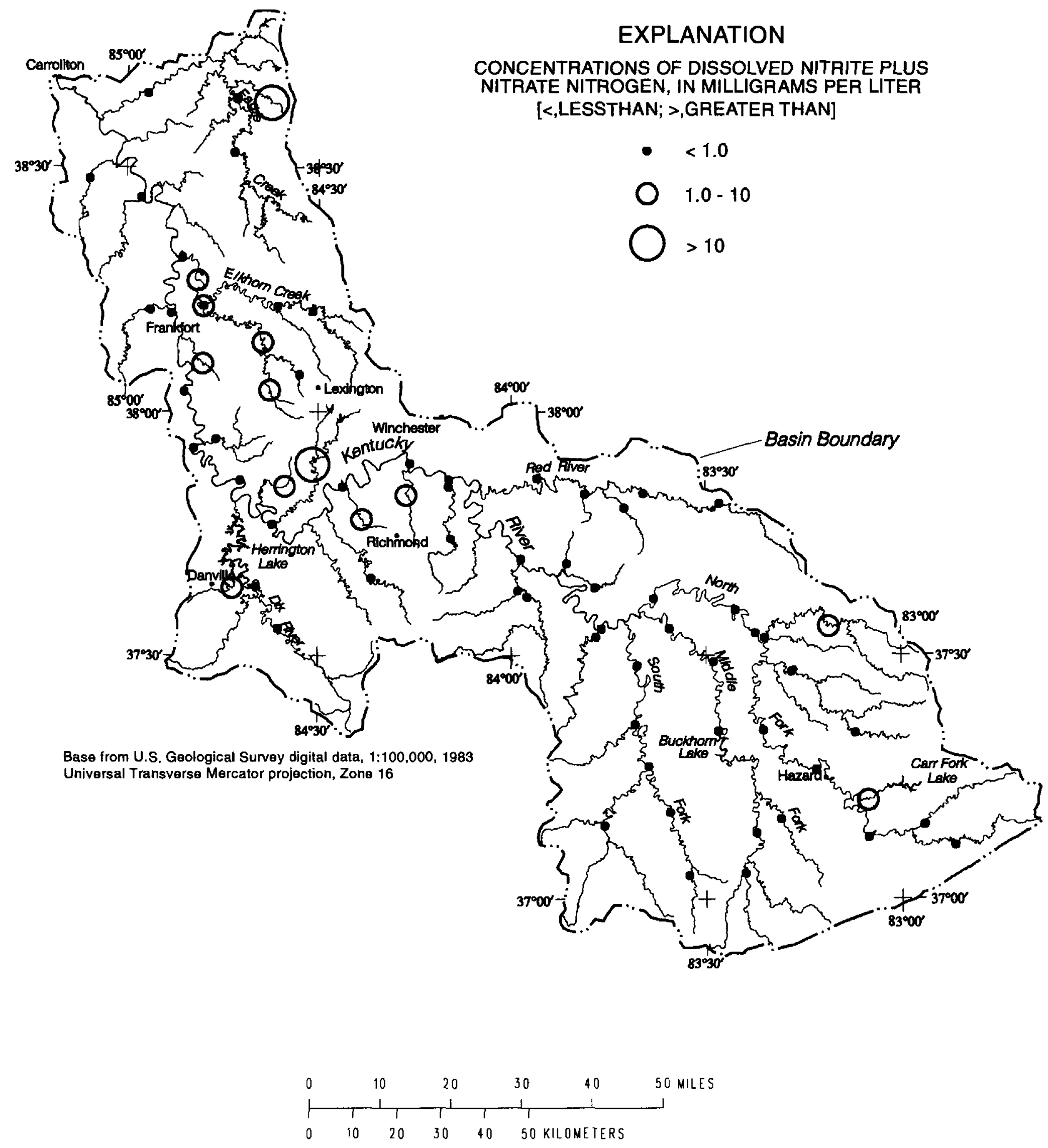

Figure 19. Concentrations of dissolved nitrite plus nitrate nitrogen at synoptic sites in the Kentucky River Basin, August 8-12, 1987. 


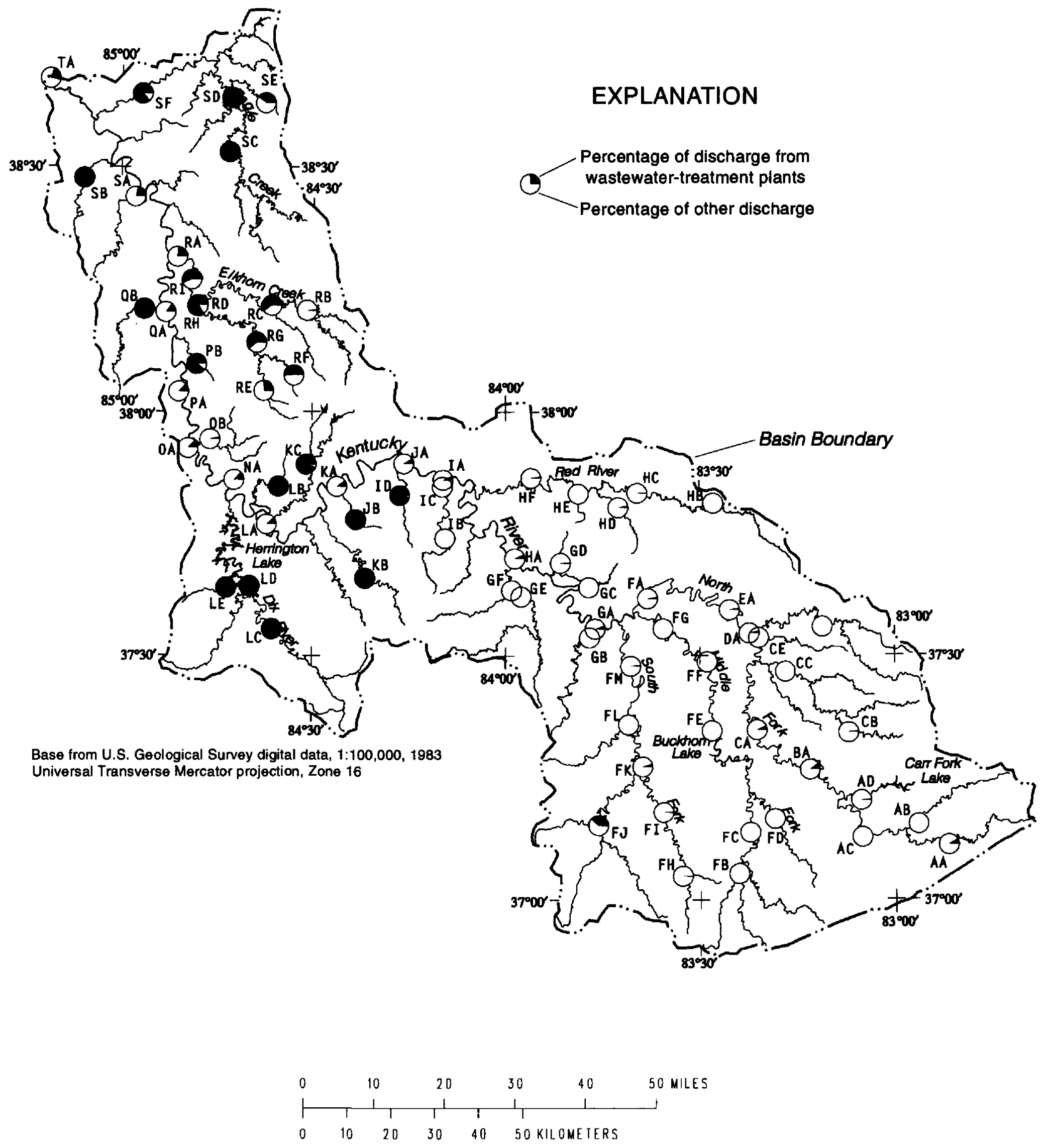

Figure 20. Percentage of total stream discharge attributable to wastewater-treatment-plant discharge in subbasins of the the Kentucky River Basin, August 1987. 


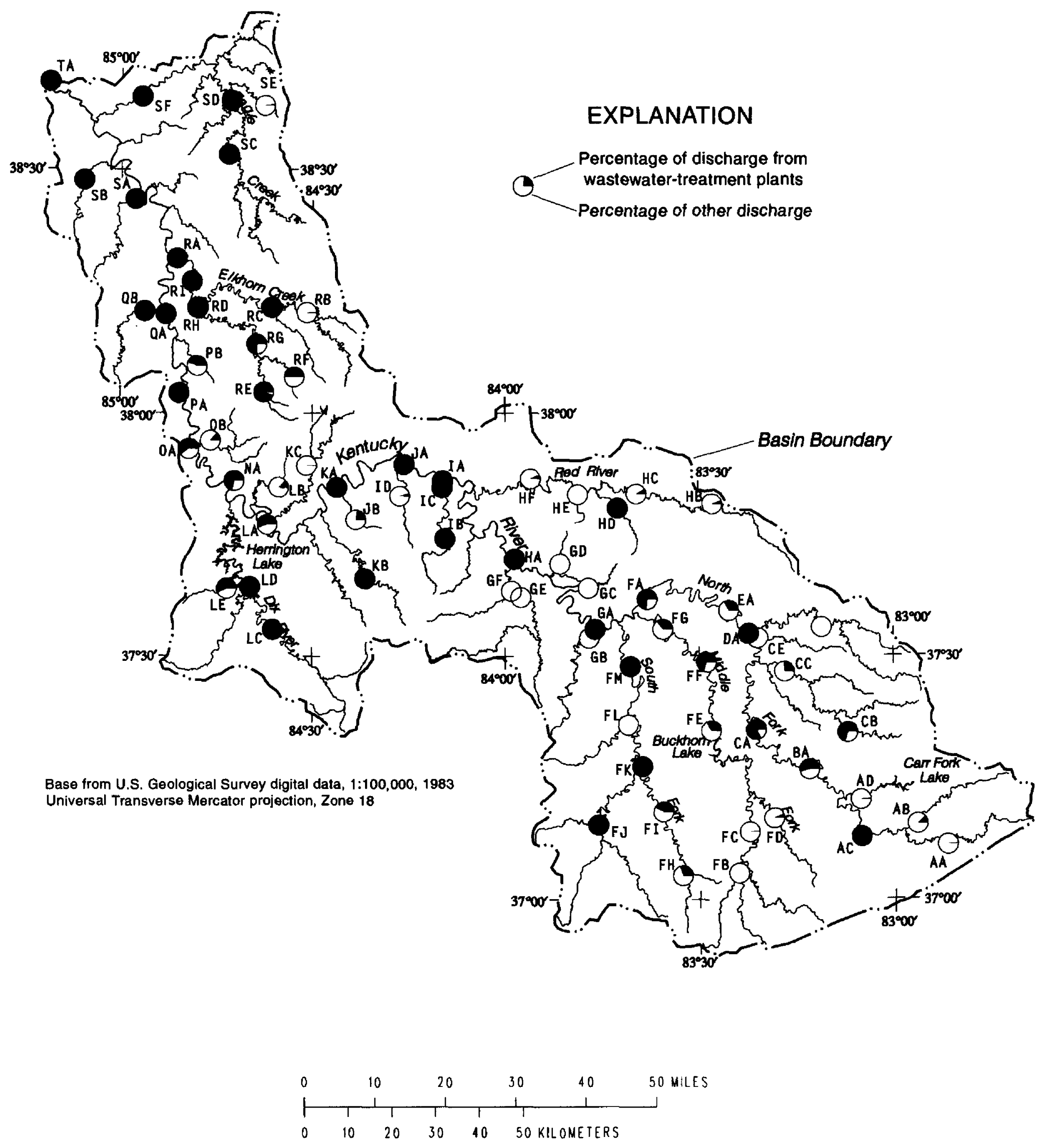

Figure 21. Percentage of total nitrogen load attributable to wastewater-treatment-plant discharge in the Kentucky River Basin, August 1987. 
instantaneous nitrogen load from WWTP effluent was conservatively estimated and was assumed to be equal to the instantaneous ammonia loads reported in table 6 .

In the upper part of the basin, WWTP effluent rarely makes up more than 10 percent of total stream discharge (fig. 20). One exception is at Goose Creek at Manchester (synoptic site FJ), where WWTP effluent accounted for about 39 percent of streamflow in 1987 . Stream concentrations of total nitrogen $(0.4$ and $0.7 \mathrm{mg} / \mathrm{L})$ and total phosphorus $(0.03$ and $0.06 \mathrm{mg} / \mathrm{L}$ ) were relatively low at site FJ in 1987 and 1988 (table 6). At this site, however, most of the estimated instantaneous stream nitrogen load was attributable to WWTP effluent. Similarly, in the South Fork Kentucky River at Oneida (FK) and at Booneville (FM) and in Leatherwood Creek at Cornettsville (AC) and the North Fork Kentucky River at Jackson (DA), most of the instantaneous stream load of nitrogen was attributable to WWTP effluent during low flow, although less than 1 percent of the total stream discharge was attributable to WWTP effluent.

In the Red River Subbasin, effluent from WWTP's contributed less than 5 percent of total stream discharge (fig. 20). Likewise, the contribution to the instantaneous stream nitrogen load from WWTP effluent was less than 10 percent, with one exception: on the Middle Fork Red River near Slade (HD), most of the instantaneous stream nitrogen load was attributable to WWTP effluent (fig. 21). At this site (HD), the concentration of total phosphorus was $0.03 \mathrm{mg} / \mathrm{L}$ and the concentrations of total nitrogen were 0.03 and $1.0 \mathrm{mg} / \mathrm{L}$ (table 6).

In the main stem of the Kentucky River downstream from the confluence with the Red River, there are several sites where most of the instantaneous stream nitrogen load is attributable to WWTP effluent, including the site near Doylesville (IA), the site at Lock 10 (JA), and the site near Valley View (KA). Concentrations of stream total nitrogen at these sites ranged from 0.60 to $1.1 \mathrm{mg} / \mathrm{L}$, and total phosphorus ranged from 0.03 to $0.05 \mathrm{mg} / \mathrm{L}$ (table 6). In the Kentucky River at Camp Nelson (LA), the proportion of stream nitrogen coming from WWTP effluent was about 56 percent. This proportion increased gradually downstream to 71 percent at the site near Highbridge (NA), and exceeded 90 percent from the site near Tyrone (PA) to the confluence of the Kentucky River with the Ohio River at Carrollton (TA), with the exception of Glenns Creek near Versailles (PB). At all of these main-stem sites, the proportion of total stream discharge attributable to WWTP effluent was always less than 20 percent ( $\mathrm{fig} .20$ ). Total nitrogen concentrations at these sites ranged from 0.50 to $0.90 \mathrm{mg} / \mathrm{L}$, and concentrations of total phosphorus ranged from 0.04 to $0.24 \mathrm{mg} / \mathrm{L}$ (table 6).

In August 1987, WWTP effluent accounted for near1y 100 percent of the stream discharge under low-flow conditions at several sites in the Dix River Basin. On the main stem of the Dix River (sites LC and LD), almost all of the instantaneous stream nitrogen load was from WWTP effluent. In Clarks Run near Danville (LE), however, only 58 percent of the instantaneous stream nitrogen load was from this source.

In the Elkhorn Creek Subbasin, with the exception of sites RB, RF, and RG, almost all of the instantaneous load of nitrogen was attributable to WWTP 
effluent even though, on average, only 50 percent of total stream discharge was from WWTP's. Concentrations of total nitrogen were very high at some of these sites, including Town Branch at Lexington (RF; $25 \mathrm{mg} / \mathrm{L}$ ) and South Elkhorn Creek near Midway (RG; $13 \mathrm{mg} / \mathrm{L}$ ). Sites in this subbasin had the highest instantaneous effluent nitrogen loads in the basin (table 6). Most total nitrogen concentrations in this subbasin exceeded $1.0 \mathrm{mg} / \mathrm{L}$, and concentrations of total phosphorus were as high as $4.0 \mathrm{mg} / \mathrm{L}$.

\section{Relation of nutrients to land use and soils}

Nonpoint sources of nutrients in the Kentucky River Basin include urban and agricultural inputs. Urban centers are most numerous in the Bluegrass Regions and include Lexington, Frankfort, Richmond, Danville, Georgetown, and Carrollton (fig. 1). Farm acreage exceeds 150,000 acres in Clark, Fayette, Henry, Owen, and Scott Counties and is as great as 250,000 acres in Madison County (fig. 22) (Kentucky Agricultural Statistics Service, 1991).

Beef cattle are the dominant livestock. However, many horses are raised in the Inner Bluegrass counties of Fayette, Jessamine, Scott, and Woodford. In Kentucky, beef cattle and horses are not typically kept in confined areas. Thus, the manure is widely distributed, and inputs to surface waters are not pulsed or concentrated (University of Kentucky, 1993a). In 1988, beef cattle numbered 50,000 to 60,000 in Madison and Lincoln Counties and 30,000 to 50,000 in Clark, Garrard, Scott, and Woodford Counties (fig. 23) (Kentucky Agricultural Statistics Service, 1991).

Dairy cattle, hogs, and poultry in Kentucky are commonly raised in confined-animal enterprises, but most of this type of animal production is outside the Kentucky River Basin. In 1988, numbers of dairy cattle were highest in Madison and Garrard Counties (>5,000 head), typically much less than 1,000 head in counties of the Bluegrass and Knobs Regions, and less than 100 head per county in the remainder of the basin. Hog production ranged from 2,000 to 5,000 head per county in most of the Bluegrass Region. Poultry production was highest in Madison and Breathitt Counties (10,000 to 20,000 birds) and ranged from 1,000 to 10,000 birds in many of the other counties in the basin (Kentucky Agricultural Statistics Service, 1991).

One major source of nitrogen and phosphorus is inorganic fertilizers applied to croplands. Statewide, more than 180,000 tons of fertilizer are applied annually, principally to corn, soybeans, and tobacco, and to a lesser extent to grass hay and pastures (University of Kentucky, 1993a). In the Kentucky River Basin in 1988, corn production was highest in Clark, Fayette, Madison, and Scott Counties, whereas soybean and tobacco production was widespread in all the counties of the Inner and Outer Bluegrass Region. Tobacco production (fig. 24) was highest in Fayette and Madison Counties $(>3,500$ acres). In the Kentucky River Basin, counties ranking highest in tons of fertilizer sold (501 to 1,500 tons) were Fayette, Madison, Lincoln, and Henry. Counties that ranked highest in nitrogen fertilizer sales were these four, as well as Scott and Woodford (fig. 25). Counties that ranked relatively high (101 to 500 tons) in phosphorus fertilizer sales were Garrard, Scott, and Owen, in addition to these four (fig. 26). An estimated 


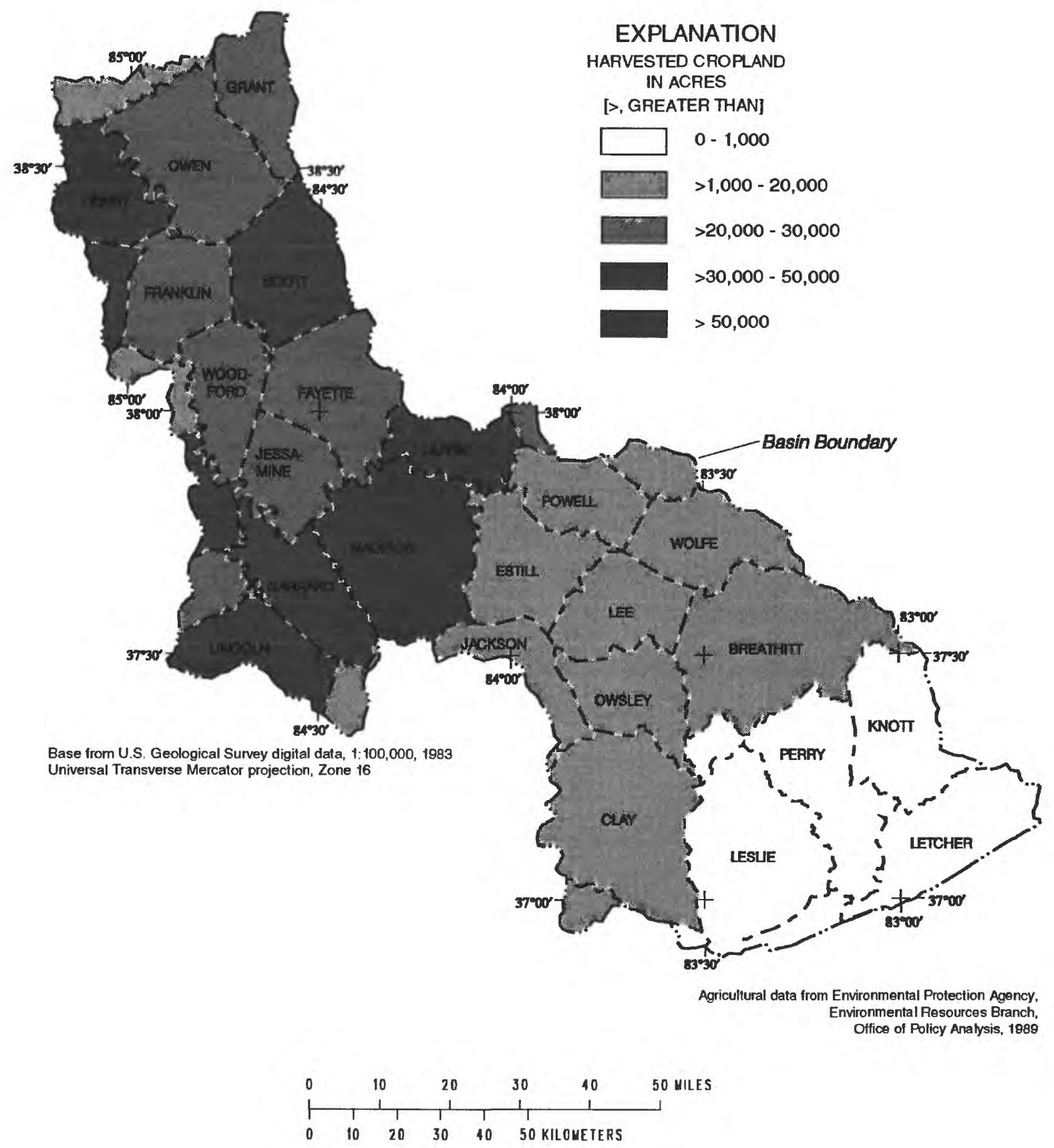

Figure 22. Harvested cropland by county in the Kentucky River Basin, 1988. 


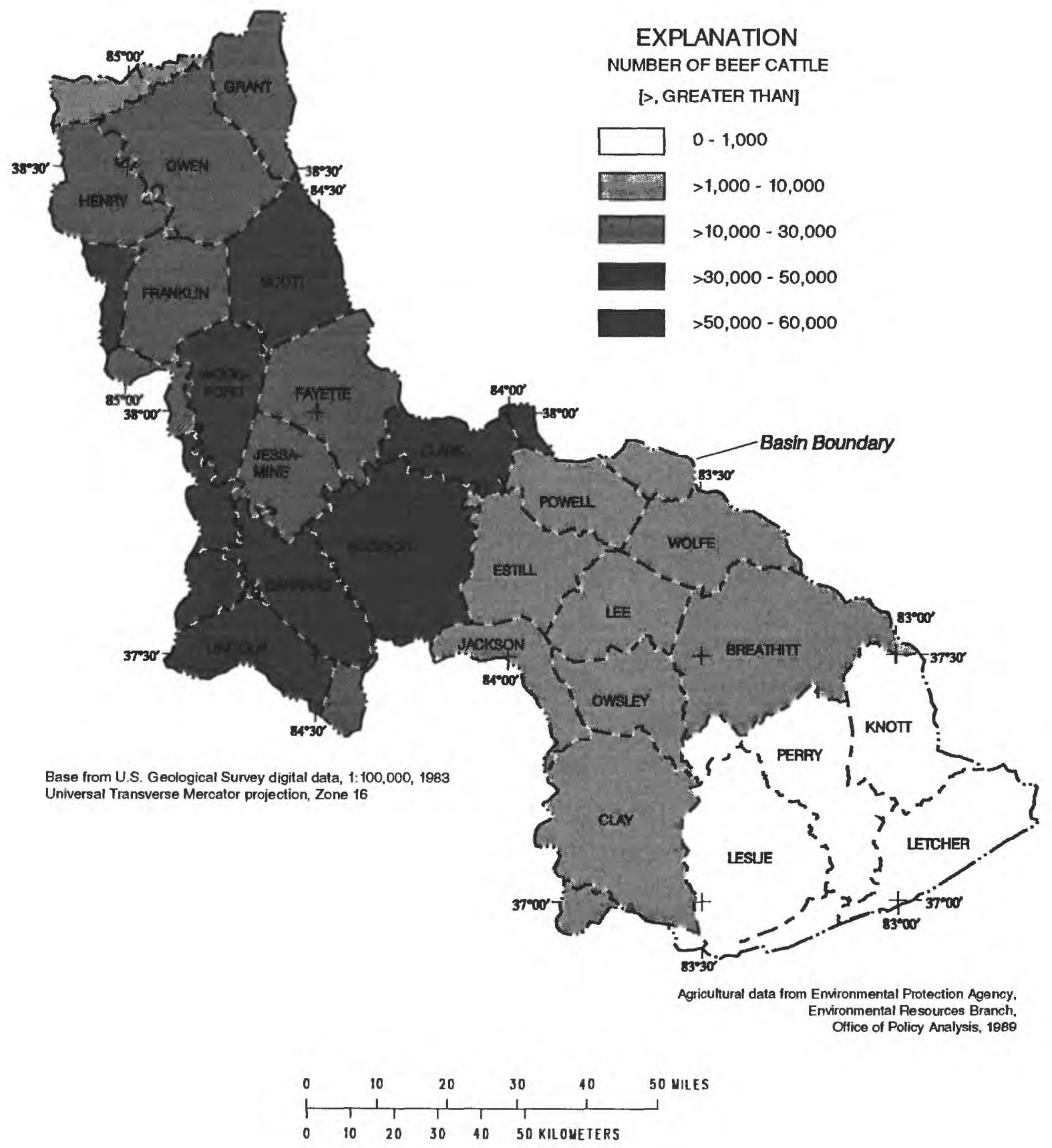

Figure 23. Numbers of beef cattle, by county, in the Kentucky River Basin, 1988. 


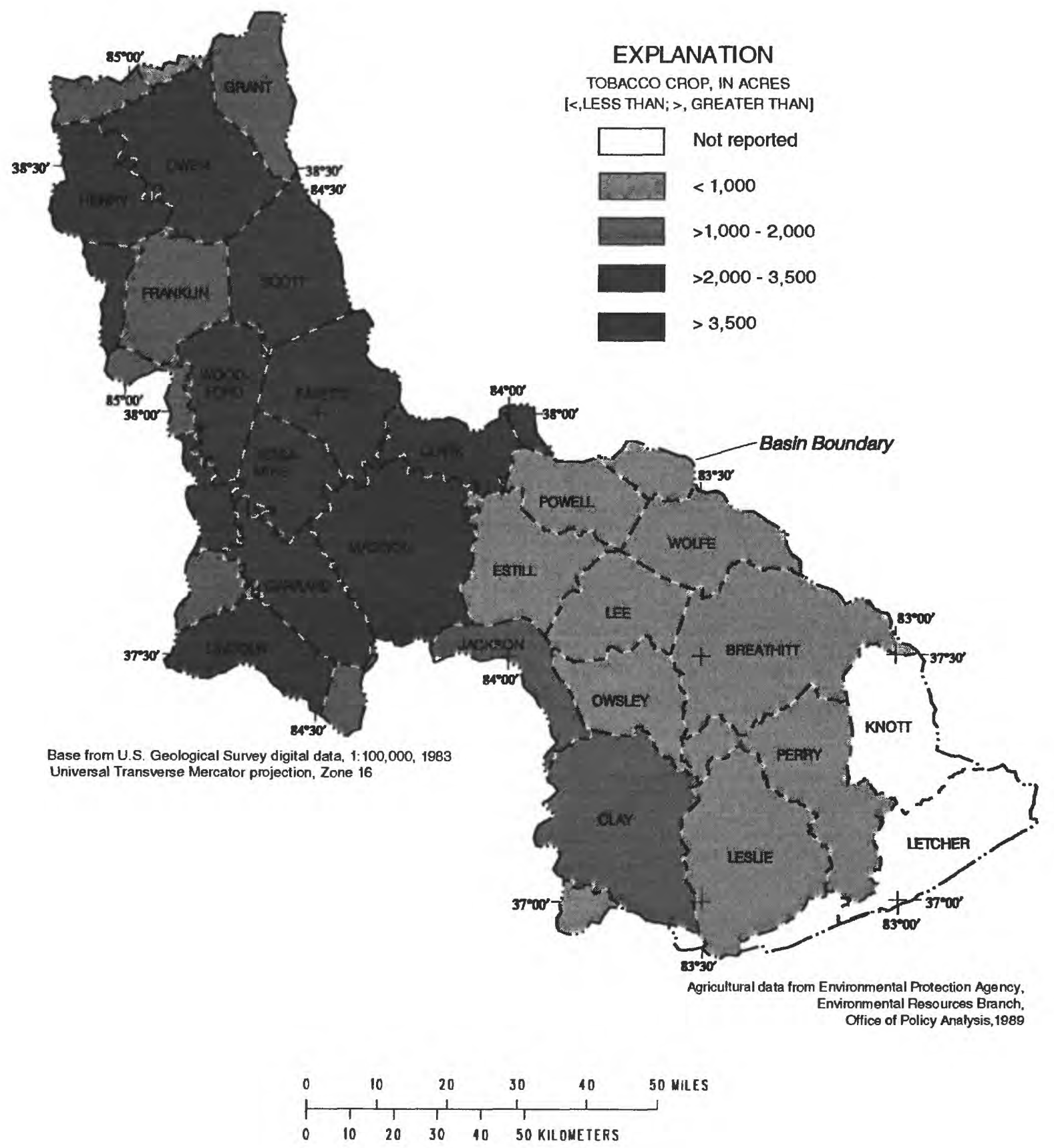

Figure 24. Tobacco production, by county, in the Kentucky River Basin, 1988. 


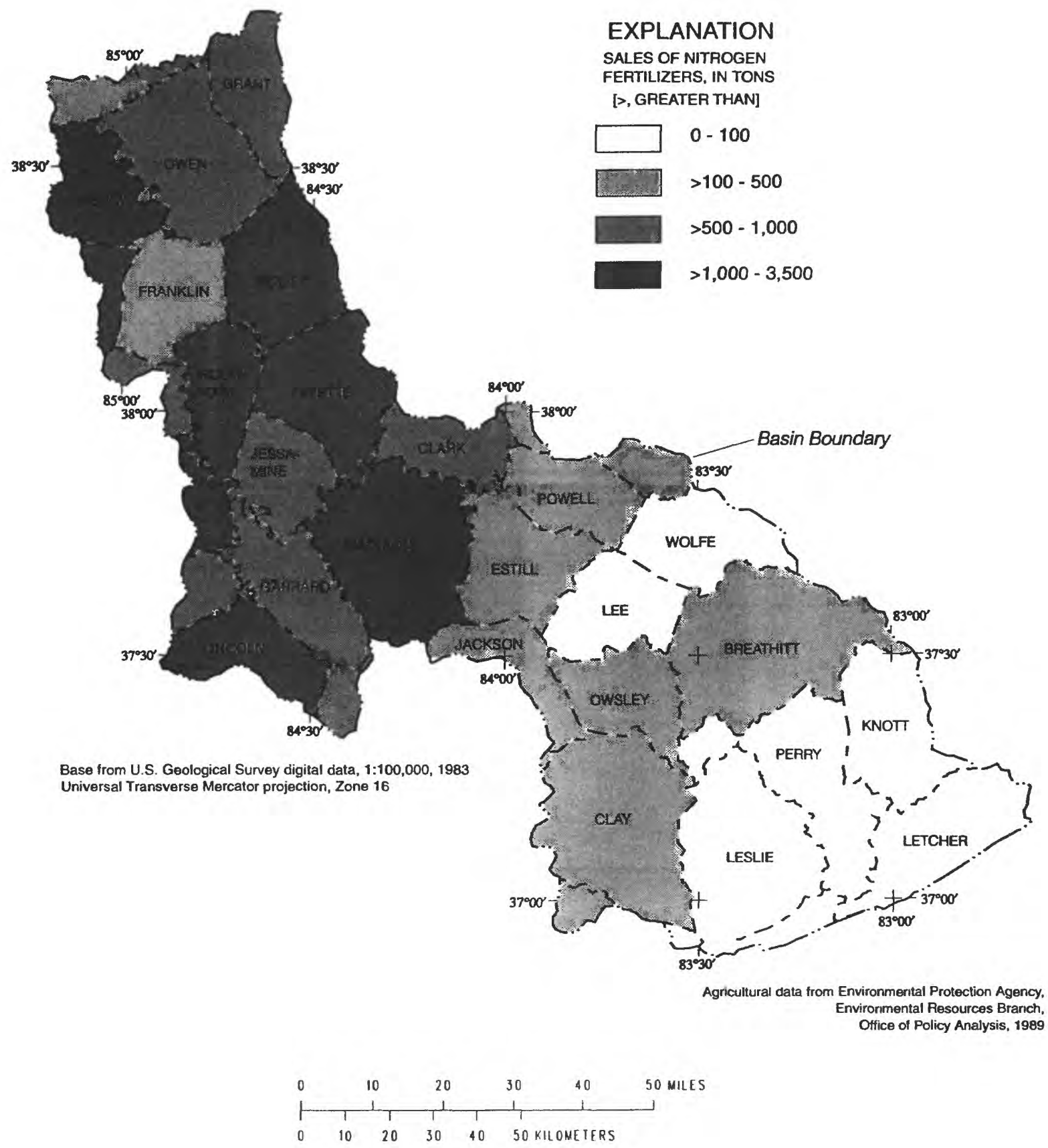

Figure 25. Sales of nitrogen fertilizers, by county, in the Kentucky River Basin, 1988. 


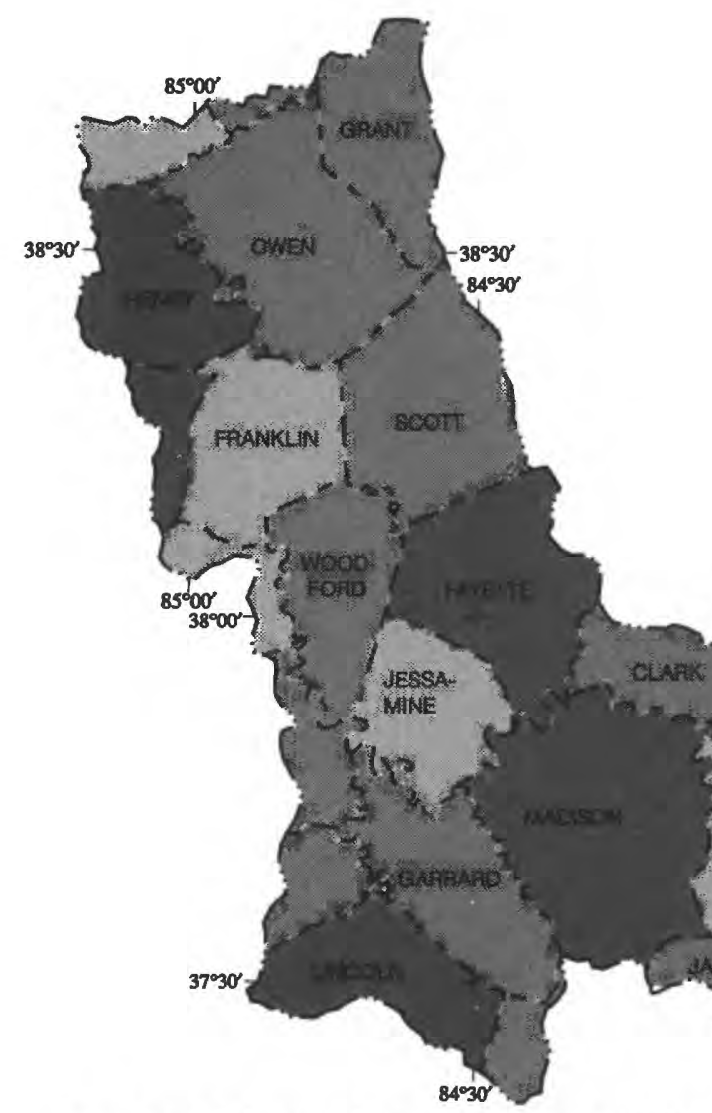

Base from U.S. Geological Survey digital data, 1:100,000, 1983 Universal Transverse Mercator projection, Zone 16

\section{EXPLANATION}

SALES OF PHOSPHORUS FERTILIZERS, IN TONS

[ $>$, GREATER THAN]

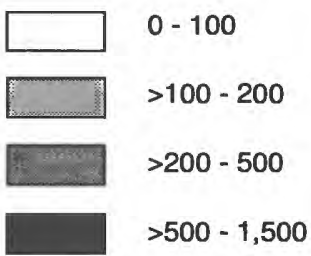

$44^{\circ} 00^{\circ}$

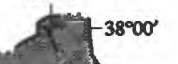

$-38^{\circ} 00^{\circ}$

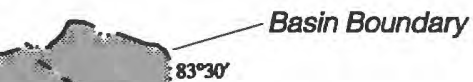

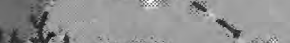

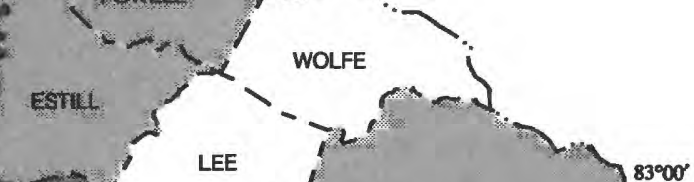

(1)

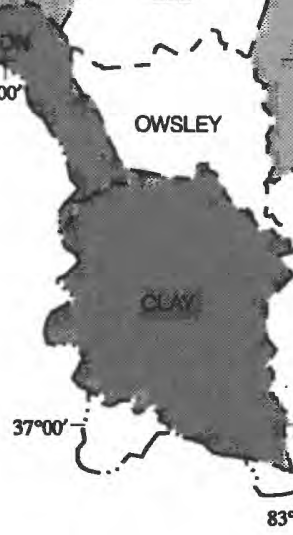
Environmental Resources Branch, Office of Policy Analysis, 1989

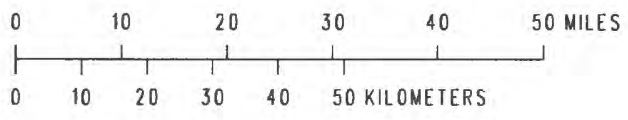

Figure 26. Sales of phosphorus fertilizers, by county, in the Kentucky River Basin, 1988. 
14,058 tons of total nitrogen and 6,330 tons of total phosphorus were sold as fertilizer in the Kentucky River Basin annually from July 1986 through June 1987 (table 7).

The data base also includes information on seasonal sales patterns of fertilizer. In the Kentucky River Basin, most fertilizer is sold (and is presumed to be applied) in the spring (table 7). The implications for surface-water quality are that large concentrations of nutrients could be flushed from cropland and transported in surface waters in response to late spring and early summer rainfall (Thurman and others, 1992).

No significant correlations between land use and total phosphorus, total nitrogen, nitrate nitrogen, nitrite nitrogen, or ammonia were found when all data from the fixed stations were combined. Concentrations of dissolved phosphorus and orthophosphorus were significantly and positively correlated with urban land use and agricultural land use, and were significantly but negatively correlated with forest and mining land use. Although patterns were similar at the synoptic sites, correlations were not significant between these nutrient and land-use variables. A finer resolution of land use type including related factors such as soil type, crop type, and land-management practices would facilitate more conclusive analyses of the relations between land-use type and fertilizer-derived nutrients in streams (Beaulac and Reckhow, 1982).

The phosphorus content of soils in the Inner and Outer Bluegrass Regions affects the concentrations of nutrients in surface water (fig. 27). Soils with highest concentrations of phosphorus $(>150 \mathrm{ppm})$ are in Fayette, Franklin, Jessamine, Scott, and Woodford Counties. These counties contain many of the synoptic sites within the Kentucky River Basin where phosphorus concentrations were elevated.

\section{Relation of nutrients to ground-water sources of constituents}

Collection of data on ground-water quality was not a part of the Kentucky River NAWQA pilot study design, but historical ground-water-quality data for some nutrient forms are available in files of the USGS office in Louisville (Faust and others, 1980). Data were collected between 1950 and 1987 in a few of the counties in the Kentucky River Basin (table 8). Average concentrations of dissolved nitrite ranged from $0.02 \mathrm{mg} / \mathrm{L}$ as nitrogen in Powel1 County to $0.32 \mathrm{mg} / \mathrm{L}$ as nitrogen in Jessamine County. Average concentrations of dissolved nitrate ranged from $0.28 \mathrm{mg} / \mathrm{L}$ in Leslie County to $2.50 \mathrm{mg} / \mathrm{L}$ as nitrogen in Jessamine County. Average concentrations of total nitrate ranged from $0.02 \mathrm{mg} / \mathrm{L}$ as nitrogen in three counties to $2.48 \mathrm{mg} / \mathrm{L}$ as nitrogen in Madison County.

Studies are ongoing in Kentucky to assess the quality of ground water and the extent of nitrate contamination. A reconnaissance of ground-water resources in the Kentucky River Basin is presented by Currens and others (1991). Preliminary data collected by the Kentucky Department of Agriculture during 1990-91 (University of Kentucky, 1993a) in Woodford and Jessamine Counties indicate average concentrations of $2.41 \mathrm{mg} / \mathrm{L}$ nitrate nitrogen in ground water. Less than 5 percent of the water withdrawn in the basin is from 
Table 7. Annual and seasonal fertilizer sales, by county, in the Kentucky River Basin, July 1986-June 1987

[Amounts are in tons. Data from U.S. Environmental Protection Agency, Office of Policy Analysis, Environmental Resources Branch, 1989]

\begin{tabular}{|c|c|c|c|c|c|c|}
\hline \multirow[b]{2}{*}{ County } & \multicolumn{3}{|c|}{ Nitrogen fertilizers, total sales } & \multicolumn{3}{|c|}{ Phosphorus fertilizers, total sales } \\
\hline & Annual & Spring & Fall & Annual & Spring & Fall \\
\hline Anderson & 154.29 & 150.81 & 3.48 & 44.62 & 43.93 & 0.68 \\
\hline Bell & 2.40 & 2.18 & .21 & 3.23 & 2.90 & .32 \\
\hline Boone & 16.28 & 11.46 & 4.82 & 8.92 & 7.08 & 1.84 \\
\hline Boyle & 285.01 & 220.40 & 64.60 & 109.56 & 90.96 & 18.59 \\
\hline Breathitt & 172.55 & 168.92 & 3.62 & 128.20 & 122.72 & 5.48 \\
\hline Carroll & 134.97 & 121.62 & 13.34 & 64.97 & 63.95 & 1.02 \\
\hline Clark & 493.74 & 435.79 & 57.94 & 205.02 & 189.18 & 15.84 \\
\hline clay & 268.00 & 235.14 & 32.85 & 233.78 & 178.77 & 55.00 \\
\hline Estill & 165.51 & 156.21 & 9.30 & 126.09 & 120.10 & 5.99 \\
\hline Fayette & $1,629.28$ & $1,234.25$ & 395.03 & 550.22 & 475.50 & 74.71 \\
\hline Frankl in & 386.76 & 365.14 & 21.61 & 119.62 & 111.40 & 8.22 \\
\hline Gallatin & 142.94 & 127.30 & 15.64 & 73.67 & 67.22 & 6.44 \\
\hline Garrard & 875.21 & 719.24 & 155.96 & 343.63 & 315.59 & 28.04 \\
\hline Grant & 469.08 & 448.94 & 20.14 & 218.77 & 210.37 & 8.40 \\
\hline Harlan & 3.56 & 3.22 & .33 & 3.74 & 3.69 & .04 \\
\hline Henry & $1,064.08$ & 964.62 & 99.45 & 413.56 & 388.84 & 24.71 \\
\hline Jackson & 178.03 & 171.46 & 6.57 & 119.98 & 113.36 & 6.62 \\
\hline Jessamine & 565.12 & 489.81 & 75.30 & 159.13 & 149.19 & 9.94 \\
\hline Knott & 12.43 & 12.01 & .41 & 12.11 & 11.69 & .41 \\
\hline Knox & 16.83 & 15.52 & 1.30 & 12.82 & 10.73 & 2.09 \\
\hline Lee & 55.74 & 50.52 & 5.21 & 46.05 & 39.80 & 6.24 \\
\hline Lestie & 28.30 & 25.40 & 2.90 & 37.10 & 30.21 & 6.88 \\
\hline Letcher & 39.32 & 36.36 & 2.95 & 50.56 & 45.90 & 4.65 \\
\hline Lincoln & $1,073.37$ & 891.87 & 181.50 & 620.15 & 560.95 & 59.19 \\
\hline Madison & 1.593 .71 & $1,385.35$ & 208.36 & $1,059.62$ & $1,010.05$ & 49.56 \\
\hline Menifee & 48.48 & 47.43 & 1.04 & 42.48 & 40.38 & 2.10 \\
\hline Mercer & 267.70 & 219.15 & 48.54 & 68.27 & 52.75 & 15.52 \\
\hline Montgomery & 42.41 & 40.00 & 2.41 & 31.07 & 29.41 & 1.66 \\
\hline Owen & 733.95 & 645.37 & 88.58 & 312.65 & 280.07 & 32.58 \\
\hline Owsley & 141.46 & 134.02 & 7.43 & 87.69 & 83.42 & 4.26 \\
\hline Perry & 29.21 & 24.74 & 4.47 & 22.06 & 21.18 & .87 \\
\hline Powell & 108.31 & 101.60 & 6.71 & 114.20 & 105.90 & 8.29 \\
\hline Rockcastle & 117.37 & 109.22 & 8.15 & 108.97 & 100.87 & 8.10 \\
\hline Scott & $1,260.82$ & 856.73 & 404.08 & 341.96 & 265.49 & 76.46 \\
\hline Shelby & 396.60 & 271.58 & 125.01 & 150.09 & 124.41 & 25.67 \\
\hline Wolfe & 77.63 & 68.51 & 9.12 & 60.01 & 55.16 & 4.85 \\
\hline Woodford & $1,007.82$ & 794.78 & 213.03 & 225.74 & 122.48 & 103.25 \\
\hline TOTAL $^{1}$ & 14.058 & 11,757 & 2,301 & 6,330 & 5,646 & 685 \\
\hline
\end{tabular}

${ }^{1}$ columns may not add to totals because of independent rounding. 


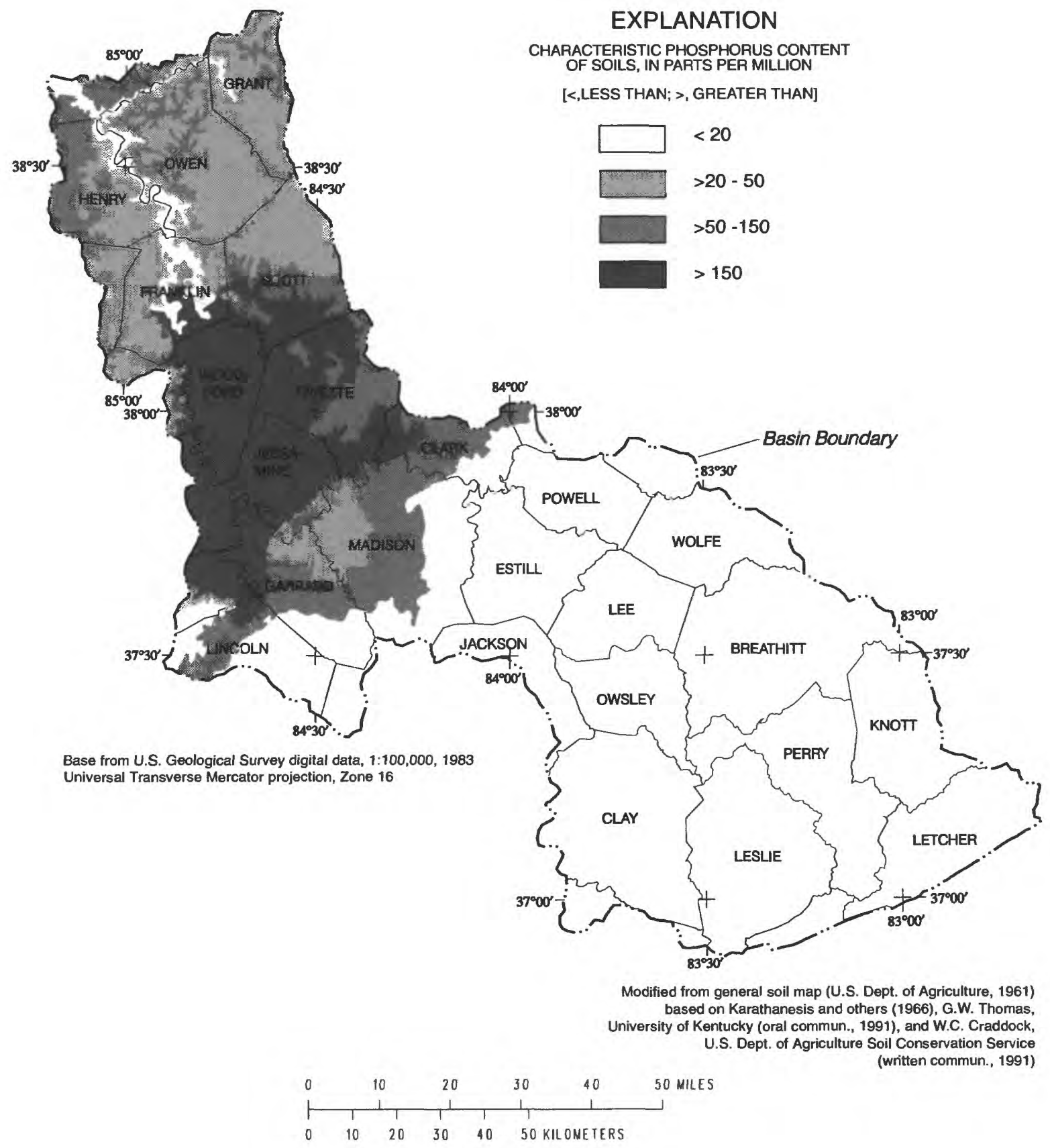

Figure 27. Characteristic phosphorus content of soils in the Kentucky River Basin. 
Table 8. Average concentrations of nitrite and nitrate in ground water, by county, in the Kentucky River Basin, 1950-87

[N, number of observations per site; mg/L, milligrams per liter;

$\cdots$, no data]

\begin{tabular}{|c|c|c|c|c|}
\hline County & $\mathbf{N}$ & $\begin{array}{l}\text { Nitrite, } \\
\text { dissolved, } \\
\text { as nitrogen } \\
\text { in } \mathrm{mg} / \mathrm{L}\end{array}$ & $\begin{array}{l}\text { Nitrate } \\
\text { total, } \\
\text { as nitrogen, } \\
\text { in } \mathrm{mg} / \mathrm{L}\end{array}$ & $\begin{array}{l}\text { Nitrate, } \\
\text { dissolved, } \\
\text { as nitrogen, } \\
\text { in } \mathrm{mg} / \mathrm{L}\end{array}$ \\
\hline Breathitt & 6 & - & 0.14 & 0.46 \\
\hline Estill & 6 & - & - & 1.70 \\
\hline Jessamine & $\begin{array}{r}1 \\
24\end{array}$ & $\begin{array}{l}0.32 \\
-\end{array}$ & $\ldots$ & $-\overline{2.50}$ \\
\hline Lee & 5 & - & - & .47 \\
\hline Leslie & $\begin{array}{l}1 \\
7\end{array}$ & -- & $\ldots$ & .28 \\
\hline Madison & 7 & - & 2.48 & $\cdots$ \\
\hline Owsley & $\begin{array}{l}1 \\
6\end{array}$ & -- & $\ldots$ & .64 \\
\hline Powel1 & $\begin{array}{l}1 \\
3 \\
8 \\
1\end{array}$ & $\begin{array}{l}.02 \\
\cdots \\
\cdots \\
\quad .02\end{array}$ & $\ldots .14$ & $\begin{array}{l}\cdots \\
\cdots \\
\cdots\end{array}$ \\
\hline
\end{tabular}


ground-water sources, and ground water is primarily used for rural-domestic and stock purposes. However, in karst areas of the Bluegrass Region, where ground-water and surface-water exchange is high, the concentration of nitrogen in ground water may be important to surface-water quality. Based on the historical data, the counties with the highest concentrations of nitrogen in ground water are Madison and Jessamine (both in the Bluegrass Region). Other studies of karst aquifers in the Bluegrass Region support this conclusion (Kiesler and others, 1986).

\section{Relation of nutrients to phytoplankton populations in the main stem}

Phytoplankton chlorophyl1 a concentrations during low flow in the Kentucky River main stem correlated positively with concentrations of total phosphorus and total ammonia plus organic nitrogen. Concentrations of nitrite plus nitrate nitrogen in the Kentucky River correlated positively with phosphorus concentrations but did not correlate with chlorophyll a.

Concentrations of nutrients and chlorophyl1 a were lowest in the main stem around Lock 14 at river mile 249 (figs. 28 and 29) and highest downstream from Lock and Dam 6 (river mile 96). Sources of nutrients upstream from Lock 14 (fig. 30) include WWTP discharges from the towns of Beattyville and Booneville. Although WWTP discharges from the towns of Jackson, Hazard, and Whitesburg contribute nutrients to the North Fork Kentucky River upstream from river mile 303, phytoplankton chlorophyll a concentrations were relatively small, probably because loads of suspended sediment from sources associated with coal-mining activities increase water turbidity (fig. 31), thereby reducing light availability for algal photosynthesis and growth. Increases in nutrient and chlorophyll a concentrations in the Kentucky River between river miles 180 and 120 (figs. 28 and 29) probably were associated with WWTP discharges from the cities of Richmond, Berea, Lexington, Nicholasville, and Wilmore to tributary streams of the Kentucky River in the Bluegrass Region. The positive correlation of chlorophyll a with total ammonia plus organic nitrogen in the Kentucky River probably indicates that a considerable proportion of total (suspended) nitrogen was transported as algal biomass during periods of low flow.

Although nutrient concentrations were largest in tributary streams that receive WWTP effluent, phytoplankton chlorophyll a concentrations and algal cell density were generally highest in the Kentucky River main stem. This might be expected because as is true in many stream systems (Hynes, 1970), nutrients were not limiting in streams of the Kentucky River Basin. Compared to tributary streams, the lower turbulence and lower stream velocity in the main stem allow longer retention times for algae and the possibility for reproduction. During stable, low-flow conditions, phytoplankton communities in the Kentucky River main stem were dominated by species that are typical of reservoirs and lakes (euplankton), whereas phytoplankton assemblages in smaller, tributary streams in the Kentucky River Basin were frequently dominated by dislodged periphyton (tychoplankton) species (Stevenson and White, 1995). Phytoplankton communities in the Kentucky River upstream from river mile 185 (near Doylesville) were dominated by green algae and flagellates, and algal cell density was less than 1,600 cells per milliliter (cells $/ \mathrm{mL}$ ). In contrast, blue-green algae (cyanobacteria) were predominant 


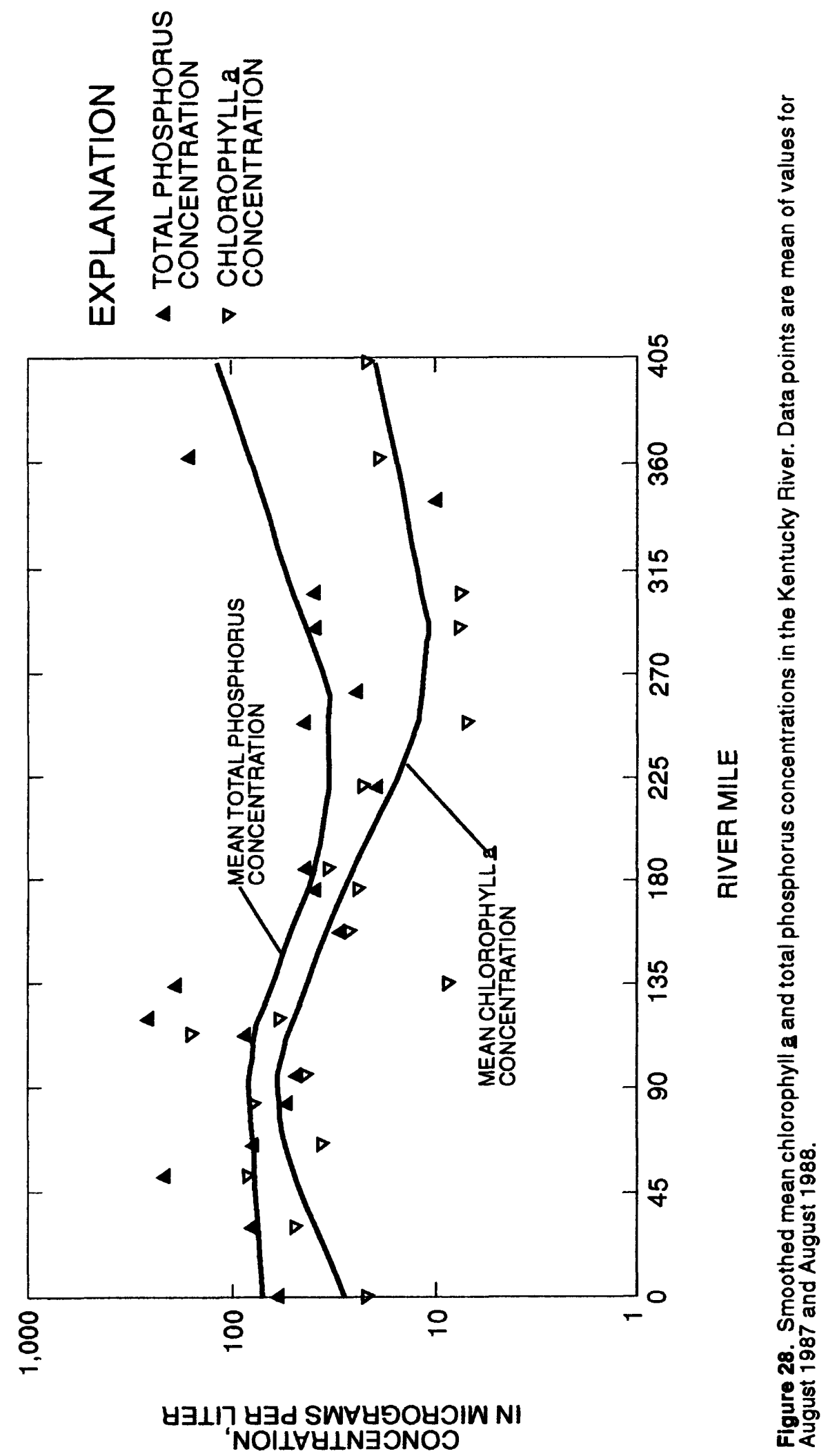




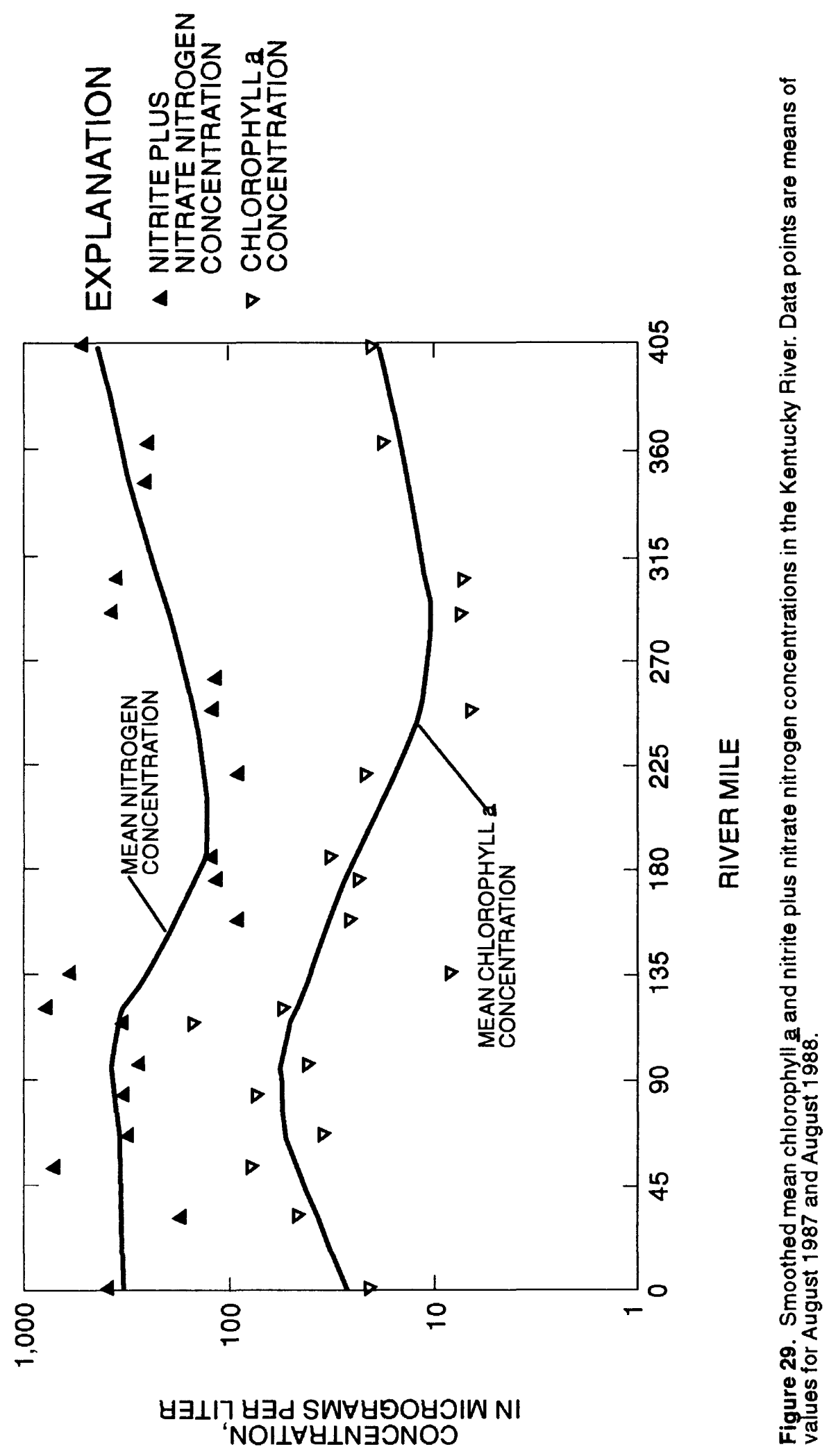




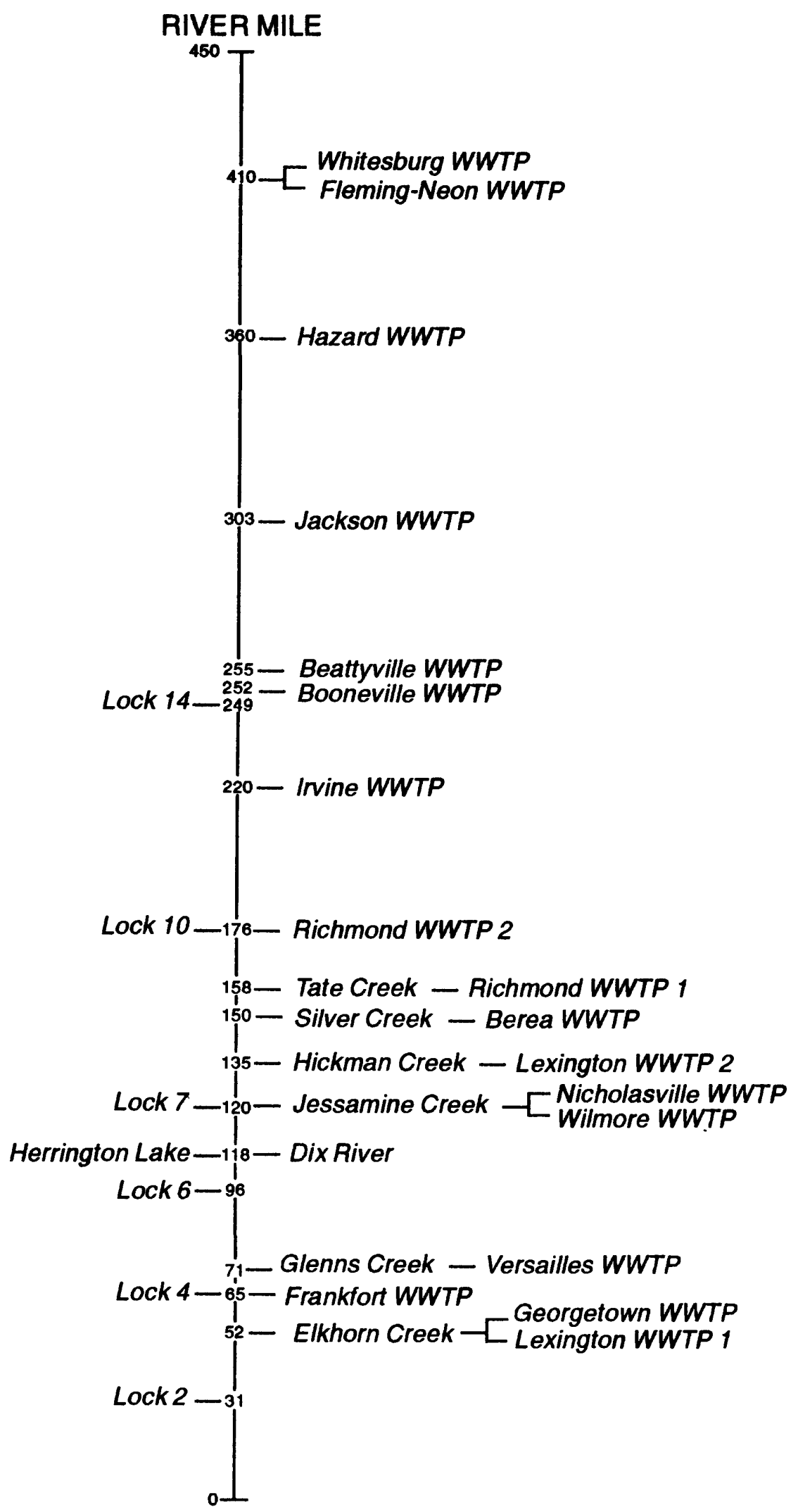

Figure 30. Location of major tributaries, navigation locks, and municipal wastewater-treatment plants (WWTP) with respect to the main stem of the Kentucky River. 


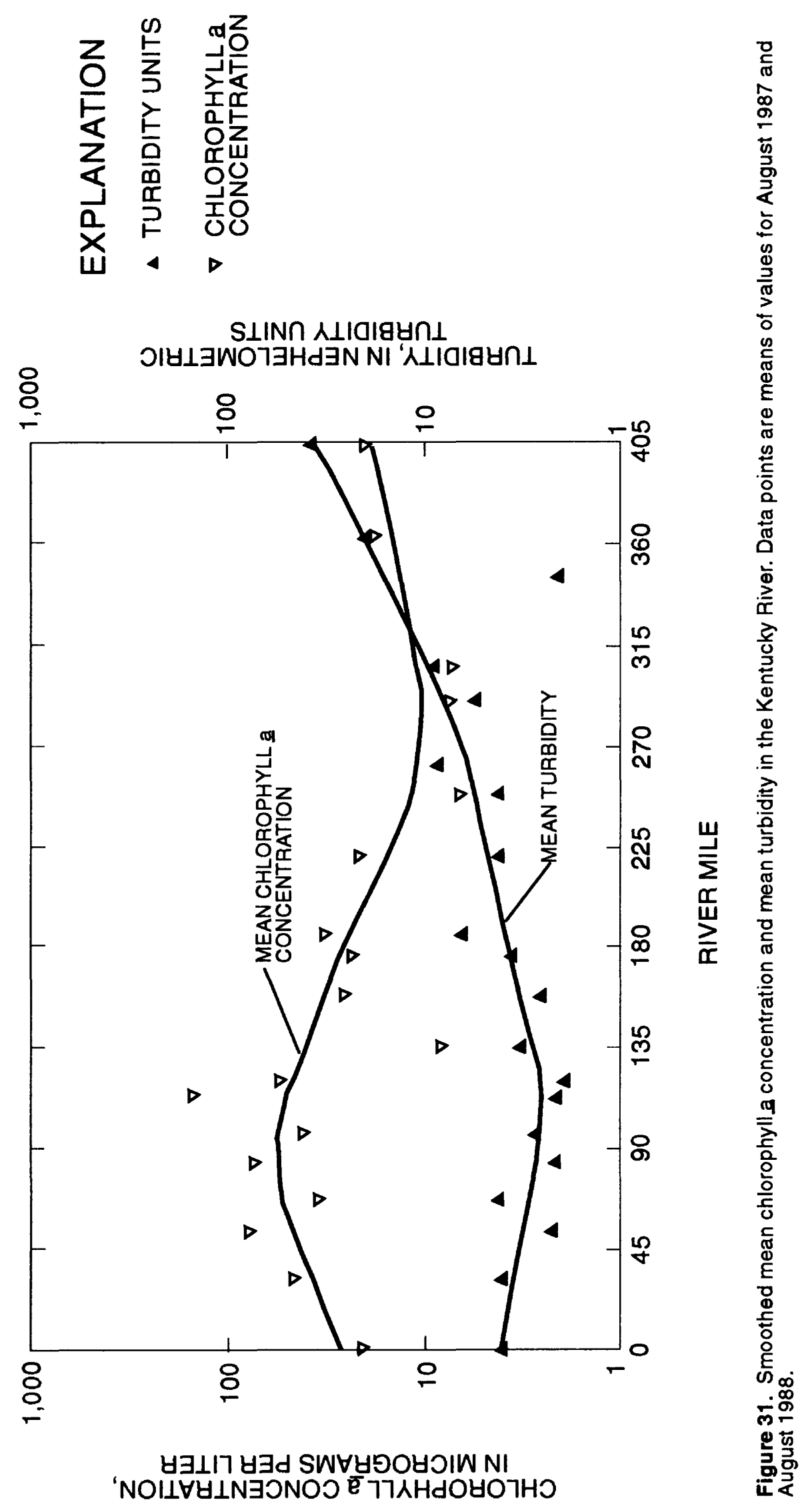


from river mile 158 (near Tate Creek) downstream to near the mouth of the Kentucky River. Large blue-green algal populations have been associated with "musty" tastes and odors in public water supplies (Mallevialle and Suffet, 1987).

The increase of phytoplankton cell density (fig. 32), from 3,600 cells/mL at river mile 158 to $34,000 \mathrm{cells} / \mathrm{mL}$ at river mile 113 , may result in increased water-treatment costs to water utilities at several locations in the pools above Locks 8 and 9 of the Kentucky River. Downstream from river mile 113, algal-cell density remained relatively constant (fig. 32), ranging from about $12,000 \mathrm{ce} 11 \mathrm{~s} / \mathrm{mL}$ at river mile 83 to $11,000 \mathrm{ce} 11 \mathrm{~s} / \mathrm{mL}$ at river mile 31 and decreasing to $5,600 \mathrm{cells} / \mathrm{mL}$ at river mile 1 . Algal-cell density in the Kentucky River correlated significantly with chlorophyll a concentrations $(r=0.69 ; p=0.009 ; n=13)$. Chlorophyll-biomass-nutrient relations in the Kentucky River are similar to those reported for lakes and reservoirs elsewhere (Canfield and others, 1985).

Nutrients indirectly affect concentrations of dissolved oxygen (DO) and $\mathrm{pH}$ in the Kentucky River by stimulating the growth and photosynthetic processes of phytoplankton. Rates of these processes may vary seasonally and by time of day. However, this study did not address seasonal or diel variability in chlorophyll a. Consequently, the relation between dissolved oxygen, chlorophyl1 a, and time of day could not be established. Dissolved oxygen does exhibit diel variability (G.L. Jarrett, U.S. Geological Survey, written commun., 1994) but this cannot be statistically related to chlorophyll a and primary production in this study. Although the concentration and saturation of Do did not correlate with chlorophyll a concentrations, changes in average DO saturation and chlorophyll $\underline{\text { a }}$ concentration during low flow in the Kentucky River main stem followed a similar pattern (fig. 33). Dissolved-oxygen saturation exceeded 100 percent from approximately river mile 120 (Lock 7 pool) downstream to river mile 52 (Lock 3 pool near Elkhorn Creek), which corresponded with the distribution of highest cell density of phytoplankton in the Kentucky River (fig. 32). Downstream from river mile 52 and upstream from about river mile 221, Do saturation decreased to about 50 percent (fig. 33), and early-morning DO concentrations were near $5 \mathrm{mg} / \mathrm{L}$.

Variations in $\mathrm{pH}$ were associated with variations in phytoplankton cell density. Values of $\mathrm{pH}$ were highest (8.0-9.0) between river miles 113-120 (near Lock 7) and decreased as chlorophyll a concentrations decreased downstream to river mile 52. Some $\mathrm{pH}$ measurements met but did not exceed the water-quality criterion of 9.0 (U.S. Environmental Protection Agency, 1992). All pH measurements were made before noon and it is likely that this criterion was temporarily exceeded during the afternoon hours as a result of photosynthesis in waters with large phytoplankton populations.

The net rate of oxygen production (NROP) in the Kentucky River main stem generally increased with chlorophyll a and nutrient concentrations, from river mile 249 downstream to about river mile 66 (fig. 34). The lower than expected NROP between river mile 176 and river mile 135 may have been associated with the relatively high chemical oxygen demand (COD) that occurred in this 40-mi segment of the Kentucky River (fig. 35). The reason for the high COD may be 


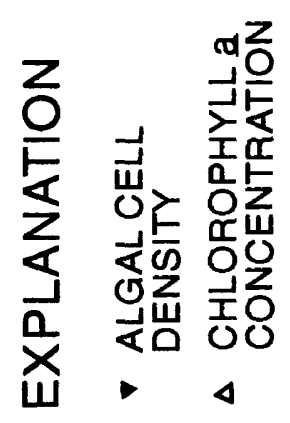

ช

8

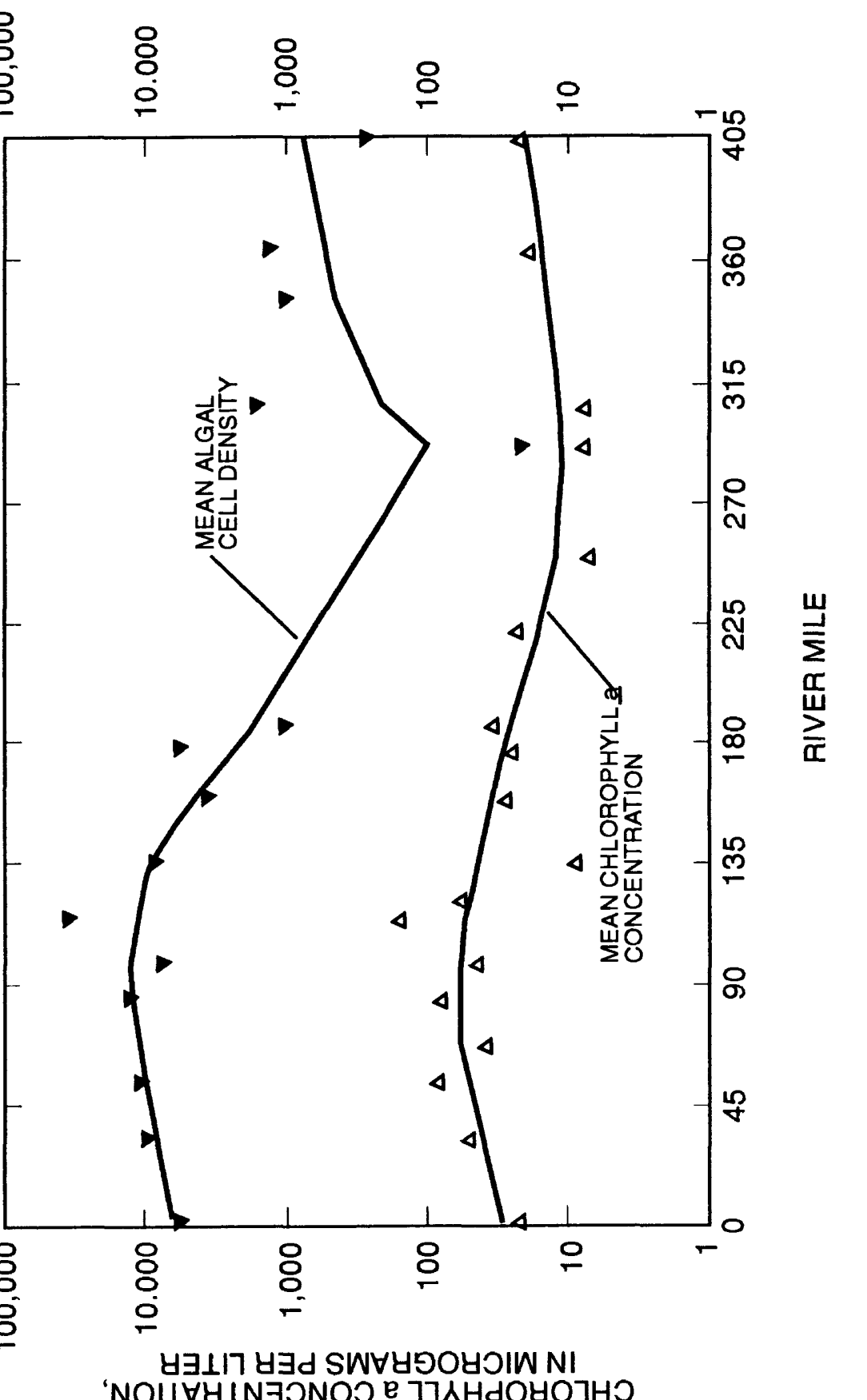

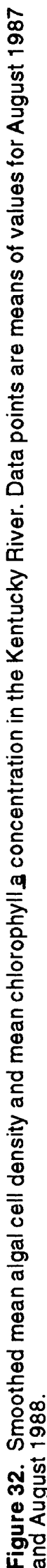




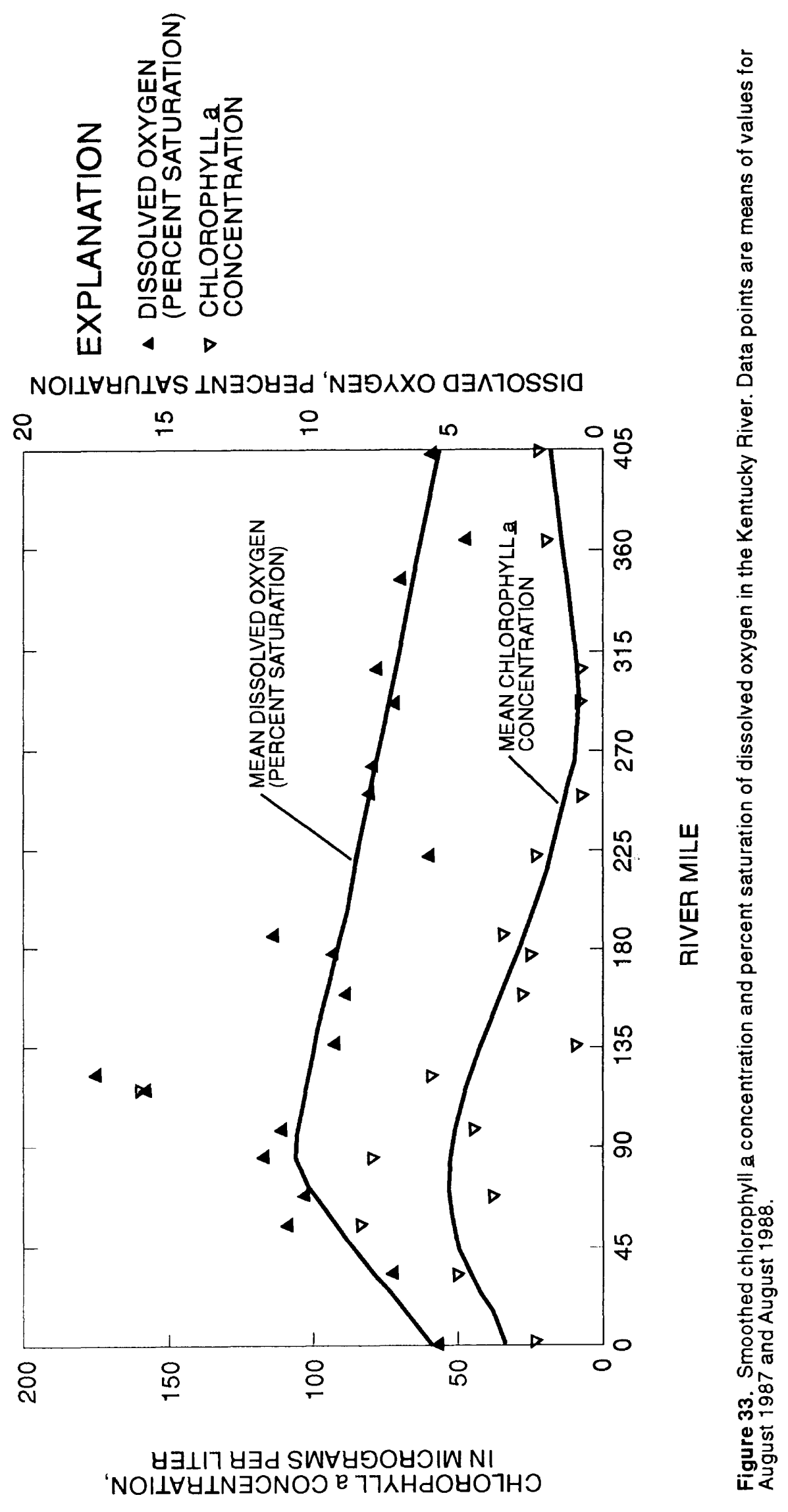




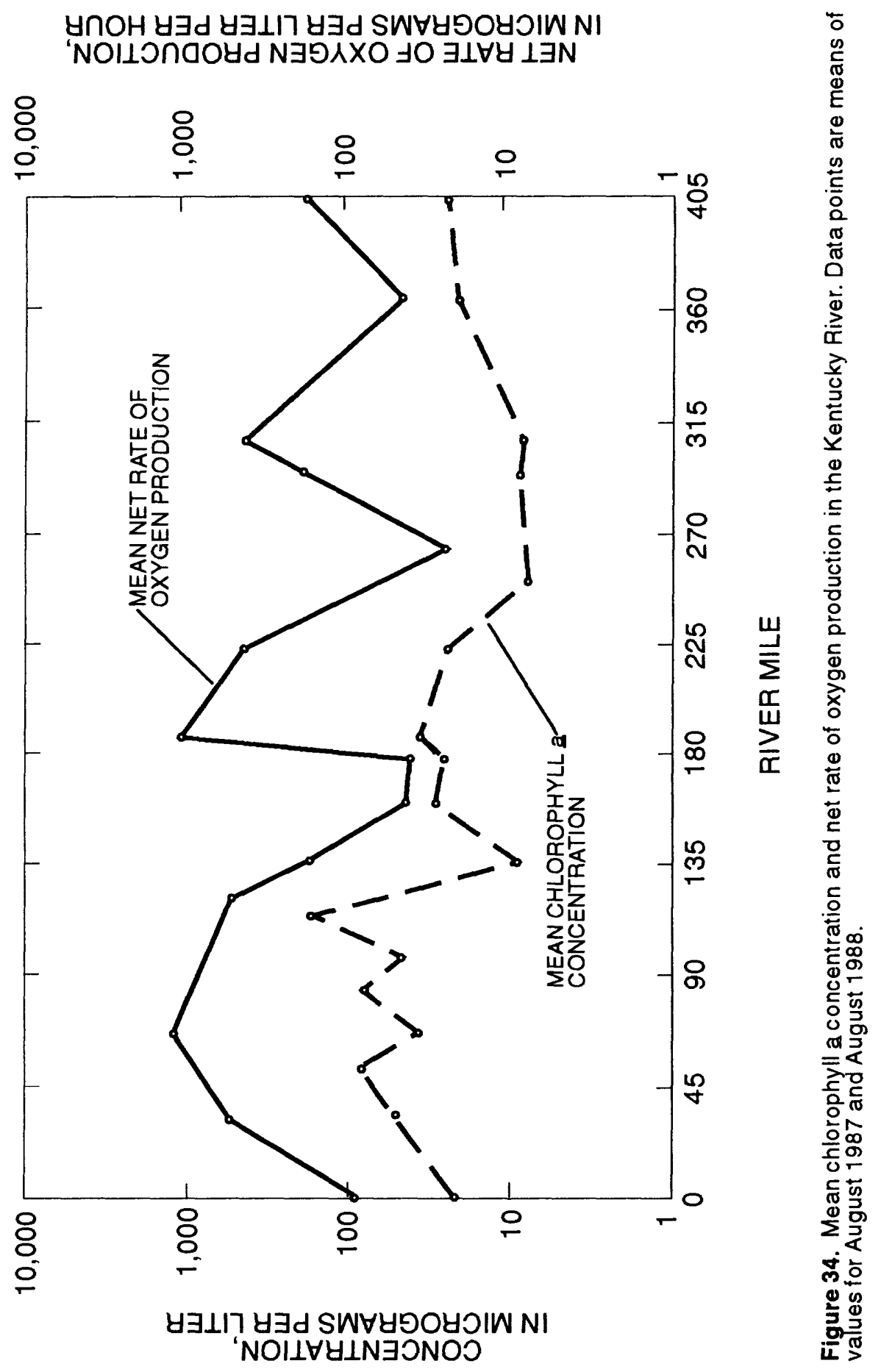




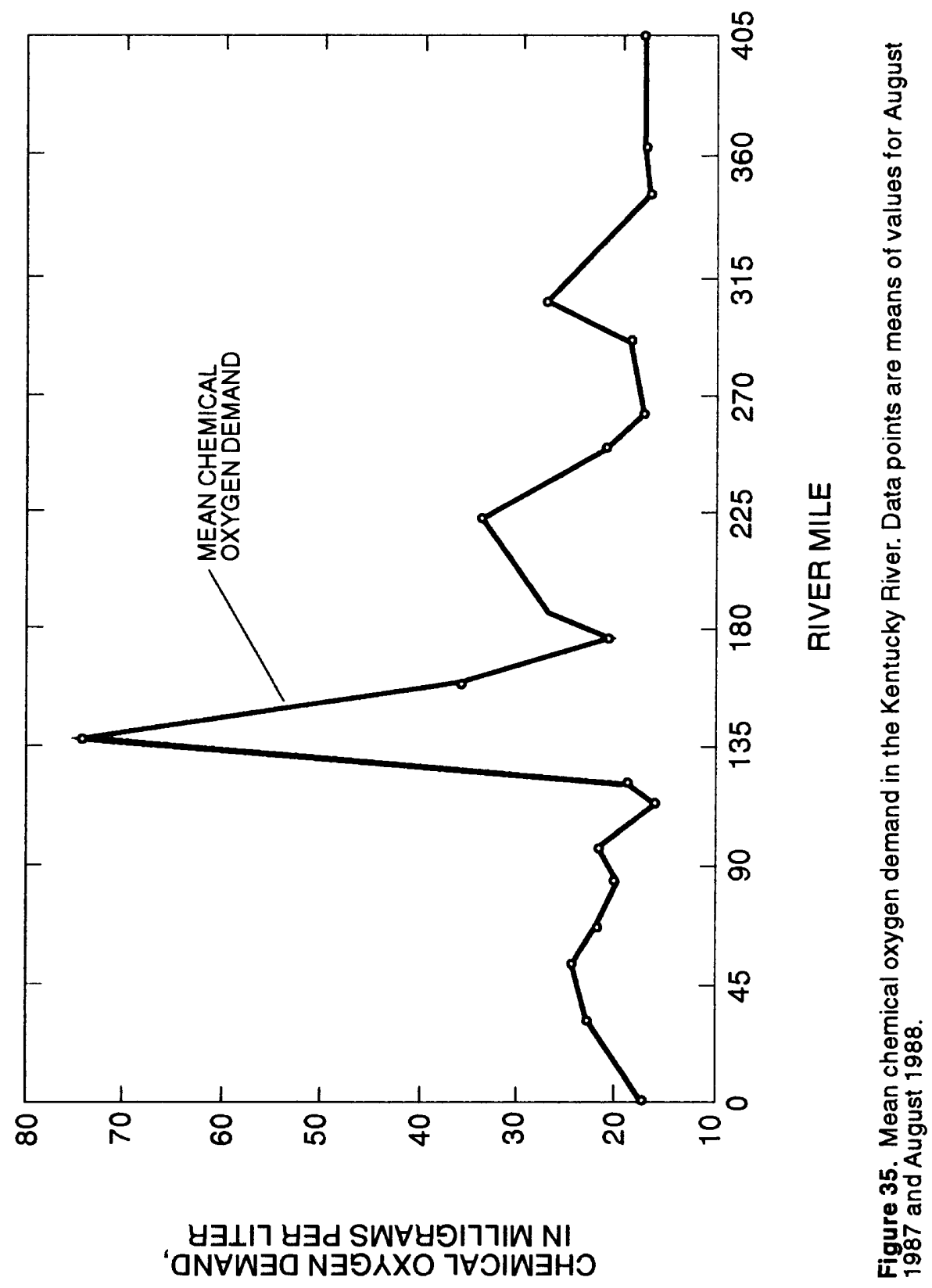


the discharge of oxygen-demanding wastes from multiple WWTP's (fig. 30). The NROP is relatively high downstream from river mile 120, and it decreases with chlorophyll a concentrations downstream from river mile 66 (fig. 34).

\section{Relation of nutrients to phytoplankton populations in tributary streams}

Phytoplankton chlorophyll a concentrations in tributary streams of the Kentucky River correlated positively with concentrations of total phosphorus and total ammonia plus organic nitrogen. Although dissolved nitrite plus nitrate nitrogen concentrations did not significantly correlate with chlorophyll a concentrations, they did positively correlate with concentrations of total phosphorus, and ammonia nitrogen did positively correlate with total ammonia plus organic nitrogen concentrations. Maximum chlorophyll a concentrations during August 1987 were greater than $165 \mu \mathrm{g} / \mathrm{L}$ in three streams [Benson Creek (QB), Glenns Creek (PB), and Otter Creek (IO); fig. 8]. Mean concentrations of chlorophyll a were greater than $25 \mu \mathrm{g} / \mathrm{L}$ in North Elkhorn Creek near Georgetown (RB), South Elkhorn Creek (RG and RH), Hickman Creek (KC), Goose Creek (FJ), Silver Creek (KB), and Town Fork near Nicholasville (LB) (table 2, fig. 36), and in several other tributary streams. Algal-cell density in these streams generally exceeded 2,500 cells/mL, and phytoplankton samples were dominated by blue-green and green algae that are indicative of nutrient and organic enrichment. These streams receive nutrient loads from WWTP discharges.

In contrast, several other streams affected by nutrient enrichment from WWTP discharges contained relatively low concentrations of phytoplankton chlorophyll a, including Town Branch (RF), Tate Creek (JB), Clarks Creek (SE), and Clarks Run (LE). The relatively high NROP (greater than $800 \mu \mathrm{g} / \mathrm{L}$ per hour) in Tate Creek, Clarks Creek, and Clarks Run indicates high algal productivity but this was likely a product of the periphyton community rather than phytoplankton in those streams. High concentrations of metals in Town Branch near Lexington (S.D. Porter, U.S. Geological Survey, written commun., 1993) may have exerted a toxic effect on algal productivity at that site.

The relation between nutrients and phytoplankton differs among streams that drain agricultural, urban, surface-mined, and forested areas. Streams that are affected by agricultural sources of nutrients in the Kentucky River Basin contain relatively higher densities of phytoplankton than streams that drain forested subbasins; however, separation of agricultural sources of nutrients from those attributable to rural WWTP's can be difficult. Median chlorophyll a concentrations and algal cell density in agricultural streams were significantly higher than concentrations and densities in forested streams or streams affected by surface mining. However, concentrations of nutrients in many of these streams were relatively small. Perhaps dissolved concentrations of nitrogen and phosphorus are being rapidly removed from the water as a result of nutrient-uptake processes of algae and other microorganisms, and nutrients are being retained and transported as algal biomass during periods of low discharge.

Median concentrations of chlorophyll a and algal cell density in urban streams $(9.5 \mu \mathrm{g} / \mathrm{L}$ and $2,600 \mathrm{cells} / \mathrm{mL})$ were not statistically different from those found in agricultural streams $(17.4 \mu \mathrm{g} / \mathrm{L}$ and $15,600 \mathrm{cells} / \mathrm{mL})$. 


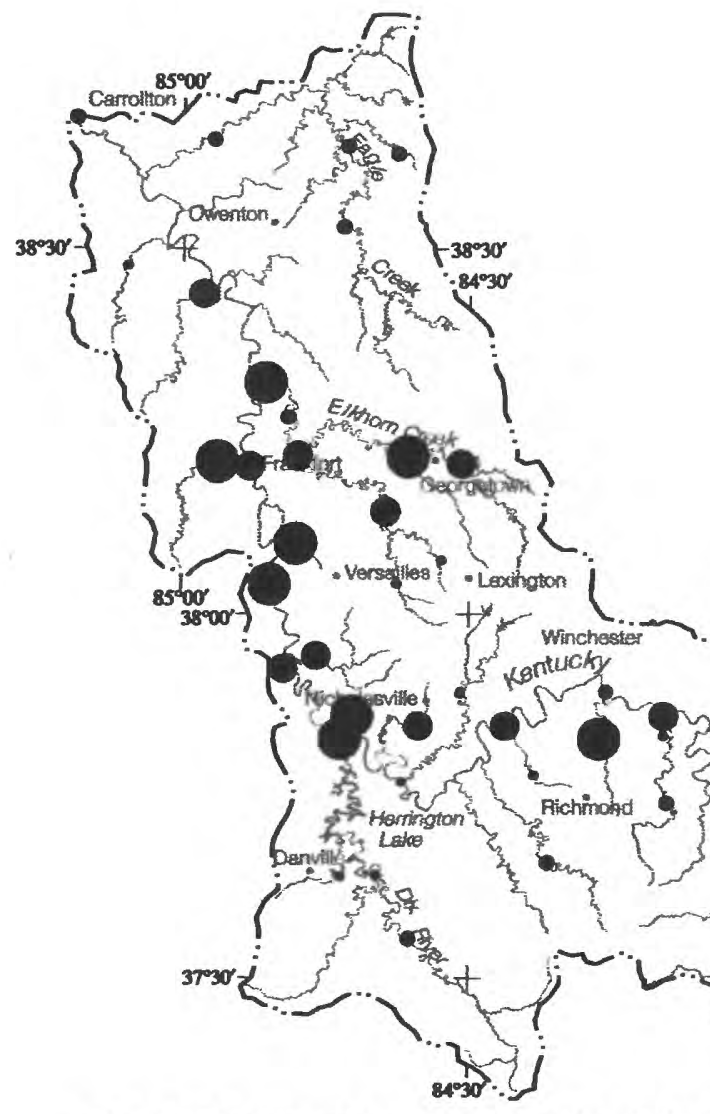

Base from U.S. Geological Survey digital data, 1:100,000, 1983 Universal Transverse Mercator projection, Zone 16
EXPLANATION

CHLOROPHYLLa CONCENTRATION,

IN MICROGRAMS PER LITER

[<, LESS THAN; >, GREATER THAN]

- $<10$

- 10-25

$>25-50$

$>50$

\section{$84000^{\circ}$}<smiles>[3H]C1CCCC1</smiles>
Basin Boundary

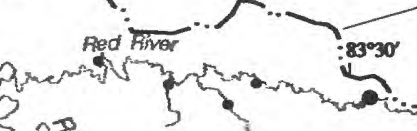<smiles>C1CCCC1</smiles> 
Moreover, algal community composition in agricultural streams was similar to that found in urban streams; that is, dominated by blue-green algae, small flagellates, and green algae. Phytoplankton species diversity, however, was lower in agricultural streams (Stevenson and White, 1995).

Median concentrations of chlorophyll a $(4.1 \mu \mathrm{g} / \mathrm{L})$ and algal cell density (930 cells/mL) were significantly lower in streams that drain forested or surface-mined areas in the Knobs and Eastern Coal Field Regions than in streams that drain agricultural and urban lands in the Inner and Outer Bluegrass Regions. Small chlorophyll a concentrations in streams affected by turbidity from surface-mining activities may have resulted from reduced light availability or toxicity associated with mine drainage. Although median concentrations of nutrients also are lower in these streams, higher concentrations of chlorophyll a in Rockhouse Creek and Quicksand Creek (fig. 36, table 2) are probably associated with nutrient loads from rural WWTP discharges. Algal communities in these streams were dominated by periphyton (benthic diatoms; Stevenson and White, 1995).

\section{Seasonal nutrient-phytoplankton relations}

Phytoplankton densities at fixed stations during 1987-90 correlated positively with water temperature, $\mathrm{pH}$, alkalinity, and total ammonia plus organic nitrogen concentrations and correlated negatively with concentrations of dissolved oxygen, ammonia nitrogen, and suspended sediment (Stevenson and White, 1995). No correlation was found between total phytoplankton density and concentrations of nitrite plus nitrate nitrogen or total phosphorus. Average phytoplankton density at fixed stations was highest during summer and fall and lowest during winter. Algal communities were dominated by green algae during winter, diatoms during spring, and blue-green algae during summer. Phytoplankton diversity changed with water-quality and hydrologic conditions. Diversity generally decreased with nutrient enrichment, and increased with changes in water quality (water temperature, specific conductance, or concentrations of metals) that altered species composition or inhibited algal growth (Stevenson and White, 1995).

\section{Temporal Trends in Nutrient Concentrations}

Opportunities to discern temporal trends in phosphorus and nitrogen concentrations (table 9) in the Kentucky River main stem were limited by data requirements of Seasonal-Kendall trend tests. The period of record is not sufficient at most stations for such analyses. Results are available, however, for four stations where eight or more years of data were collected. A significant downward trend was detected in the North Fork Kentucky River at Jackson $(p<0.075)$ for total phosphorus. No significant trend was evident in the Kentucky River at Lock 2 on the basis of data for 1975-90. Data collected by the KDOW during 1980-90 indicate significant downward trends in total phosphorus in Eagle Creek at Glencoe. A significant $(p<0.088)$ upward trend in concentrations of dissolved nitrite plus nitrate was found in the Middle Fork Kentucky River at Tallega during 1982-90. 


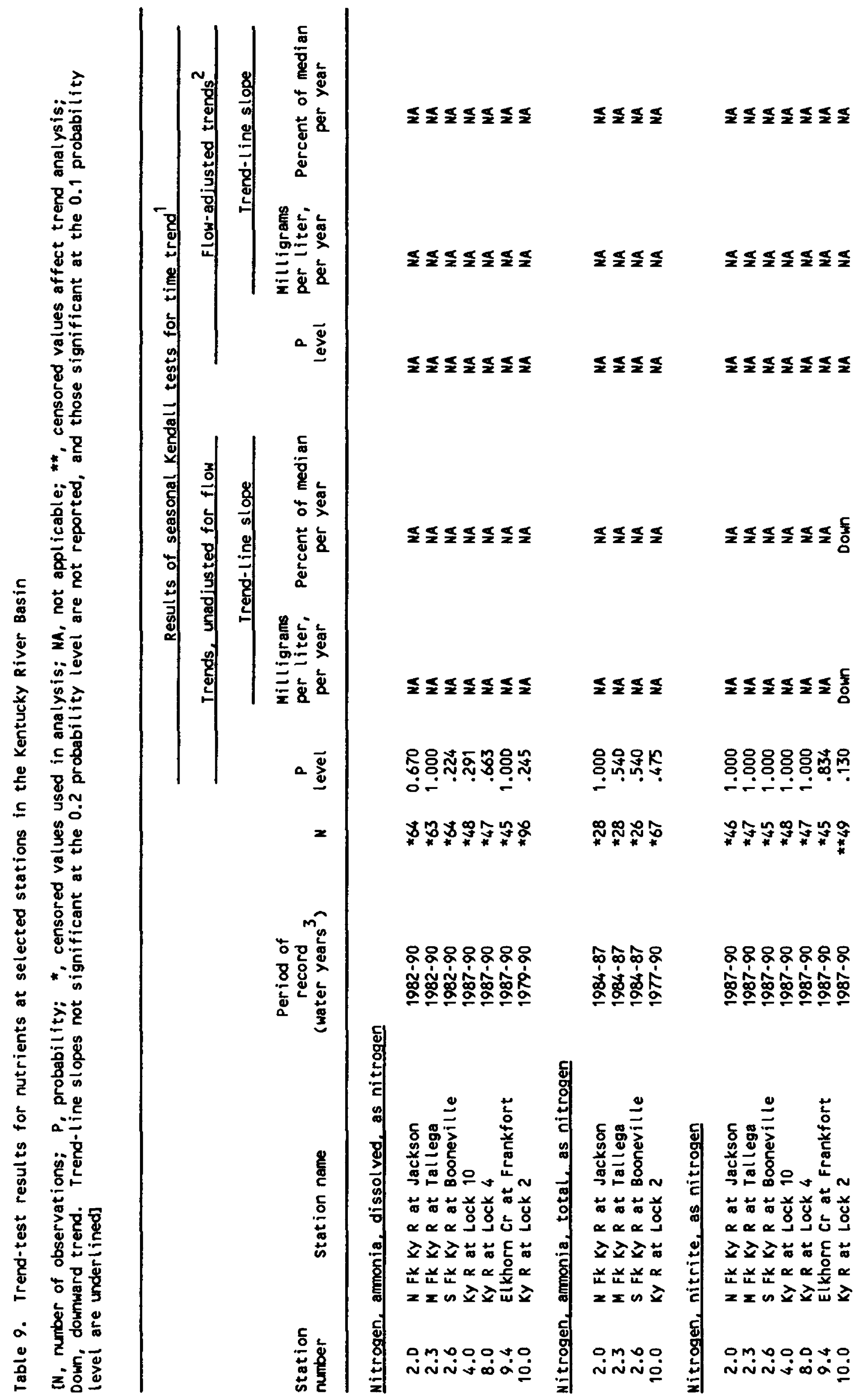




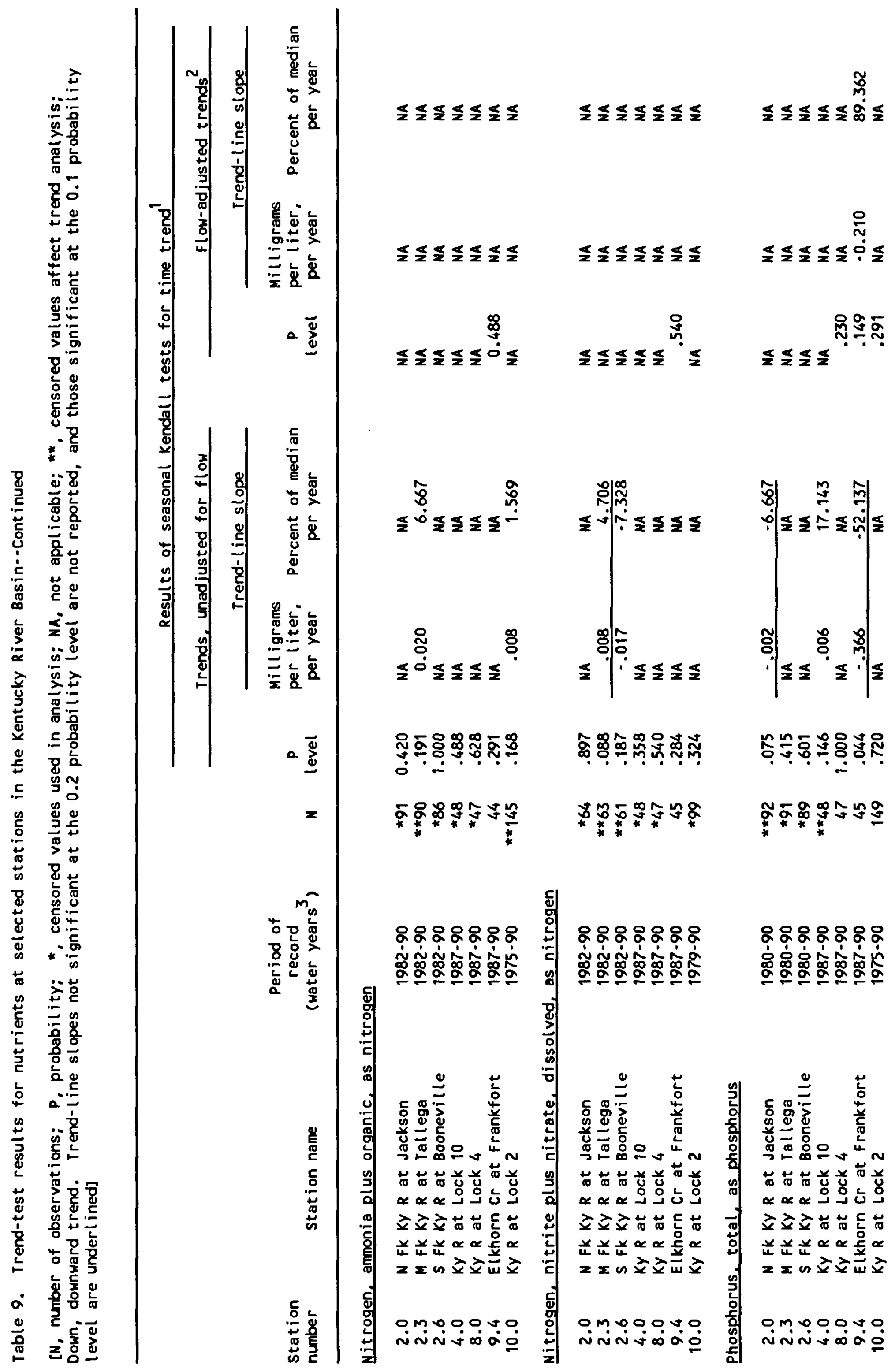




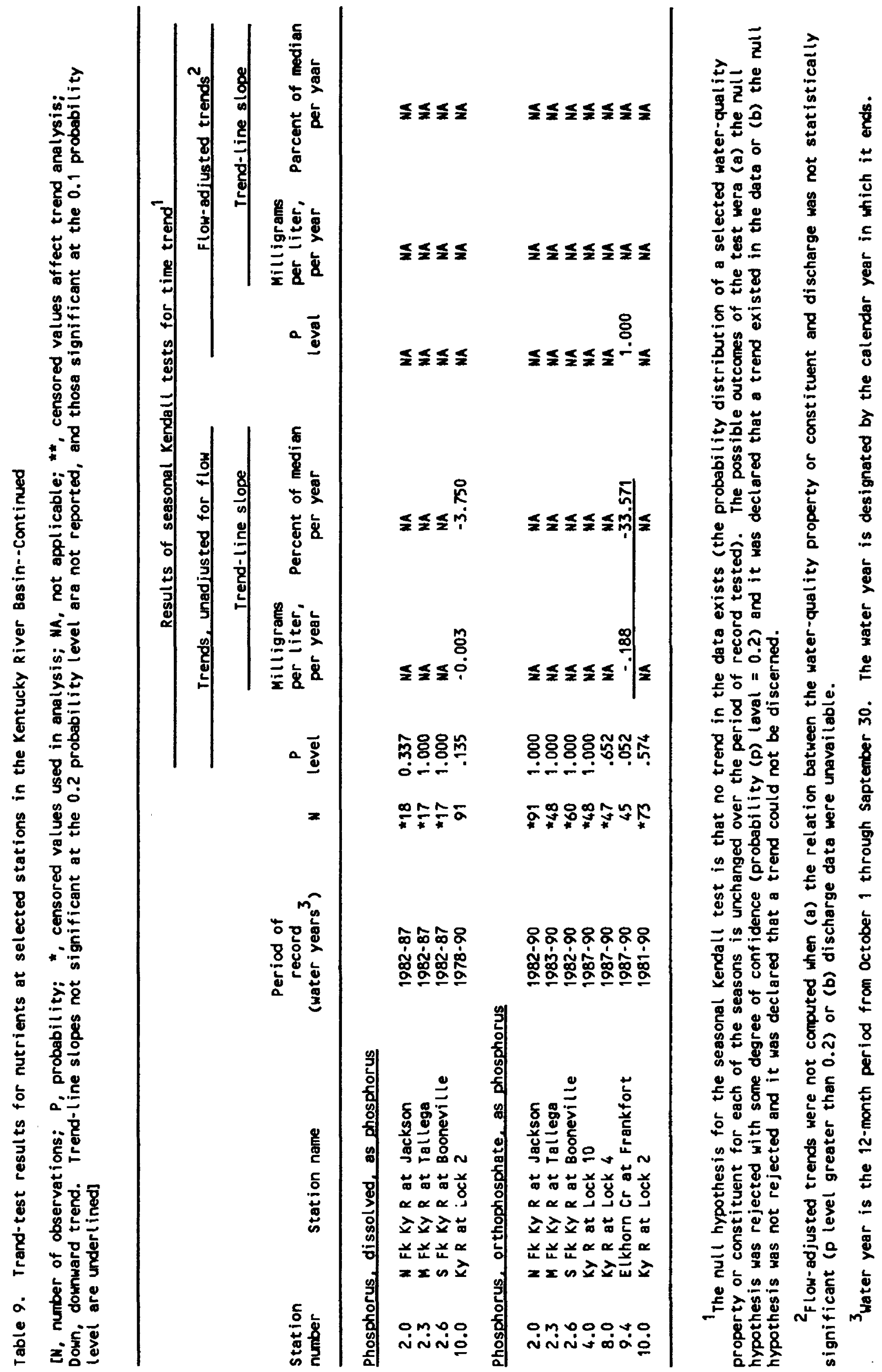




\section{Suspended Sediments}

The presence of sediments in surface waters directly and indirectly affects various water-quality characteristics and the biotic community. Therefore, suspended-sediment samples were collected through time and at specified sites throughout the basin to provide information on spatial and temporal distribution.

\section{Spatial and Temporal Distribution}

The spatial and temporal distribution of sediments was assessed by analyzing samples collected during the 3 -year study at the fixed stations (table 10). A summary of data collected by the KDOW is included for comparison. Median concentrations of suspended sediment collected at the NAWQA sites are higher than indicated by KDOW data at the four paired stations (North Fork Kentucky River at Jackson, Middle Fork Kentucky River at Tallega, South Fork Kentucky River at Booneville, and Kentucky River at Lock 4, Frankfort). As discussed in an earlier section, this discrepancy probably resulted from differences of sample-collection methodology. Because of correlative relations between concentrations of nutrients and concentrations of suspended sediment, the water-quality data and transport estimates from this study will differ from those from the KDOW.

Among the fixed stations, the median concentration of suspended sediment was lowest in Elkhorn Creek at Frankfort (10 mg/L; table 10). Median concentrations were highest in the North Fork Kentucky River at Jackson $(30 \mathrm{mg} / \mathrm{L})$ and in the Kentucky River at Lock 10 and Lock $2(31 \mathrm{mg} / \mathrm{L})$. A greater proportion of samples contained elevated concentrations of suspended sediment in the North Fork Kentucky River at Jackson, and this site had the highest maximum suspended-sediment concentration $(1,780 \mathrm{mg} / \mathrm{L})$ of all the fixed stations. The maximum suspended-sediment concentration was lowest in the Middle Fork Kentucky River at Tallega ( $302 \mathrm{mg} / \mathrm{L}$ ), probably because of suspended-sediment retention by Buckhorn Lake upstream from this site.

Suspended-sediment particle size and surface area are significant factors controlling sediment chemistry. Finer-sized sediment particles have a higher capacity for sorption of organic compounds, because they tend to have higher organic matter content (Witkowski and others, 1987). The median concentration of suspended sediment classified as silt and clay (less than $63 \mu \mathrm{m}$ ) ranged from 74 percent (Middle Fork of Kentucky River at Tallega) to 89 percent (Kentucky River at Lock 2) at the fixed stations, excluding Elkhorn Creek (table 10). In Elkhorn Creek at Frankfort, the median concentration of finegrained suspended-sediment particles was 68 percent.

Moreover, fine-grained sediments, because of their large surface areas, are the main sites for the collection and transport of inorganic constituents (Horowitz, 1991). The median estimated surface area of suspended sediment ranged from a low of $15.85 \mathrm{~m}^{2} / \mathrm{g}$ (square meters per gram) in the North Fork Kentucky River at Jackson to a high of $21.52 \mathrm{~m}^{2} / \mathrm{g}$ in the Kentucky River at Lock 10. Differences between sites were not statistically significant. 


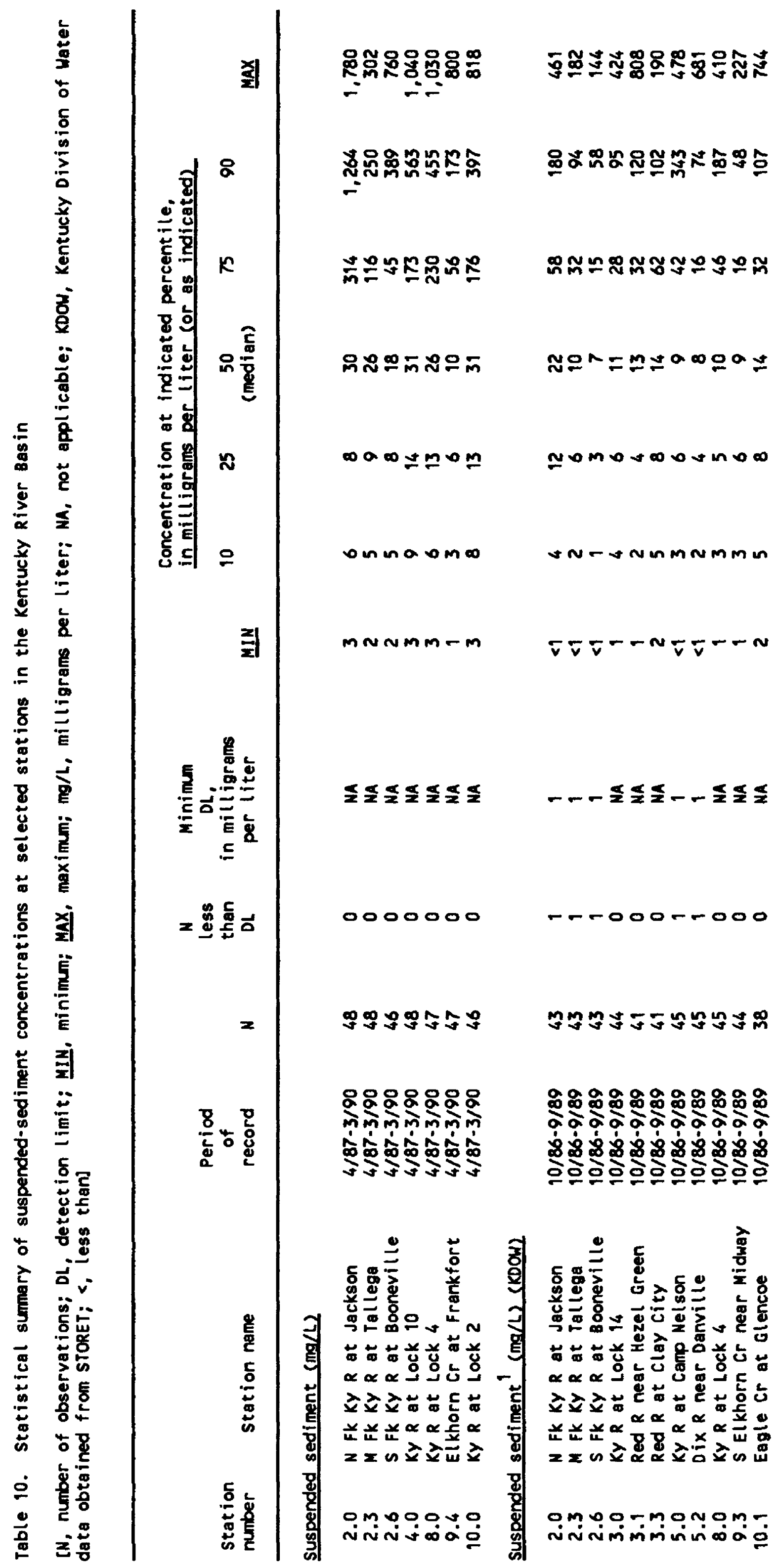




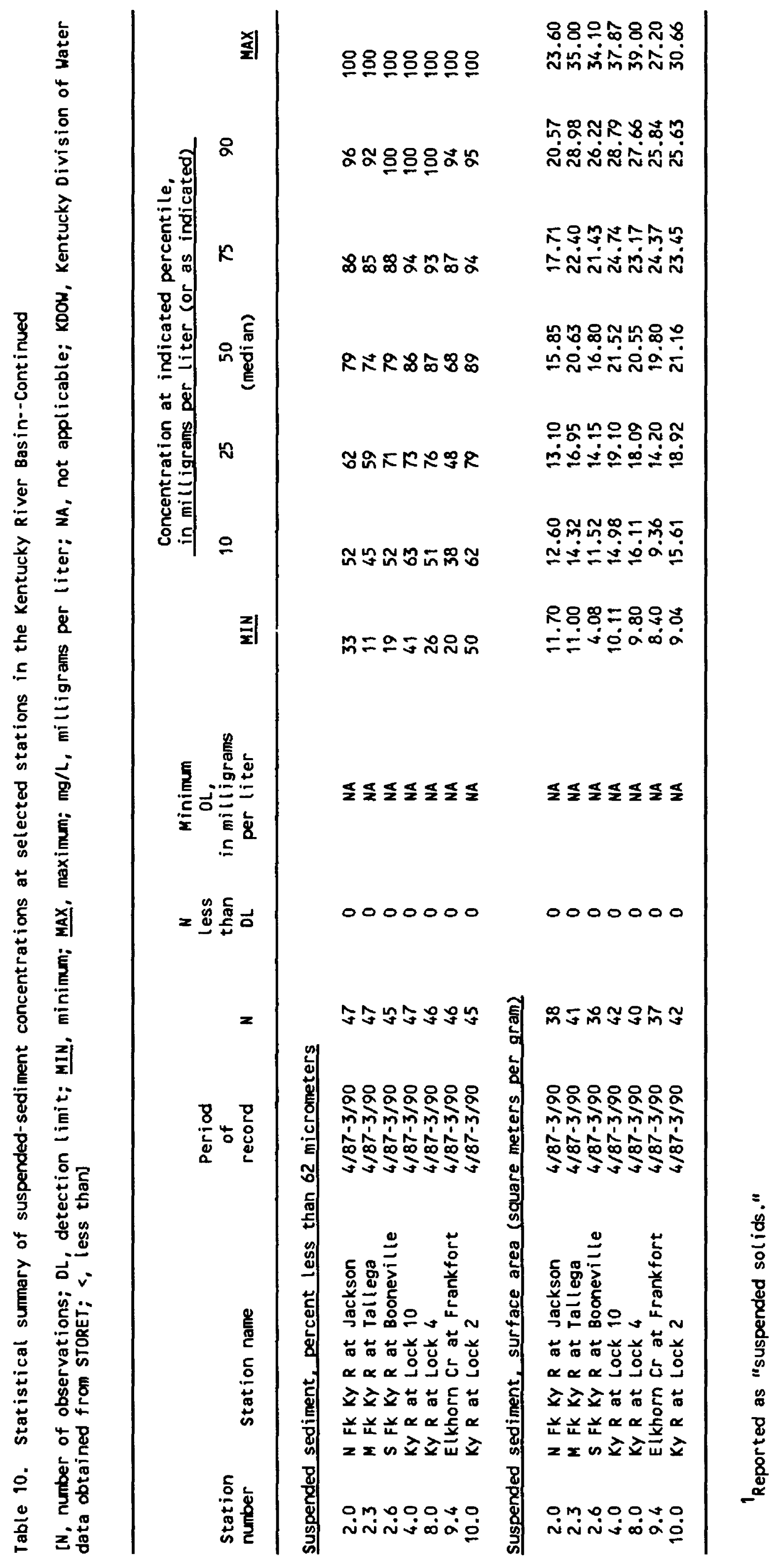


In water years 1987 and 1988, a consistent downward trend in suspendedsediment concentrations ( $f i g .37$ ) was detected in the Kentucky River main stem from the headwaters to the mouth. Concentrations declined rapidly from the headwaters to about river mile 270 on the main stem and then declined more gradually downstream to river mile 176 (Lock 10). From river mile 176 (Lock 10) downstream to the mouth, suspended-sediment concentrations remained relatively low.

Concentrations of suspended sediment were consistently higher in 1989 than in the two previous water years at all fixed stations. Data for the North Fork Kentucky River at Jackson and for the Kentucky River at Lock 2 are shown in figure 38. Moreover, the variation in sediment concentrations from month to month was also much greater in 1989 than at other times in the 3-year sampling period. Higher daily mean discharge in 1989 (fig. 4) was the likely cause of the high suspended sediment concentrations.

\section{Estimation of Suspended-Sediment Loads and Yields}

Estimates of mean annual suspended sediment loads (table 11) are much higher in the North Fork Kentucky River at Jackson (1,040,000 tons) than at the other two stations in the upper part of the basin $(116,000$ tons in the Middle Fork Kentucky River at Tallega; 212,000 tons in the South Fork Kentucky River at Booneville). This location receives drainage from surface-mining activities in the North Fork Kentucky River Subbasin, and a large part of the total sediment transport in the Kentucky River originates in the North Fork Kentucky River Subbasin. Estimates of the mean annual suspended-sediment load increase in the Kentucky River main stem downstream to 1,600,000 tons in the Kentucky River at Lock 2. Mean annual suspended-sediment-load estimates are much lower in Elkhorn Creek at Frankfort (139,000 tons). Singh and Durgunoglu (1992) reported a suspended-sediment load of 60,780 tons for E1khorn Creek on the basis of a nonlinear rating curve; however, the source of the data for these estimates is not given.

A further understanding of sediment transport can be developed by examination of annual load estimates obtained from KDOW data (table 11). KDOW data indicate that (1) a considerable sediment mass of more than 7 million tons/yr is deposited upstream from Lock 14, and (2) sediment transport increases in the middle part of the Kentucky River Basin as a result of suspended-sediment contributions from the Red River and other tributary streams of the Knobs Region ( $f i g .3$ ). Overall, about 40 percent of sediment mass transport in the middle reach of the Kentucky River (at the Lock 10 and Camp Nelson) originates in the Eastern Coal Field Region, and about 60 percent originates in the Knobs Region. The increase in the estimated suspendedsediment load in the Kentucky River between Lock 4 and Lock 2 seems to be related largely to the transport of sediment from agricultural and urban landuse activities in the E1khorn Creek Subbasin.

\section{Relation of Suspended-Sediment Concentrations to Discharge}

Suspended-sediment concentrations averaged for the entire study period were highly correlated with discharge at the fixed stations (figs. 39-41), 


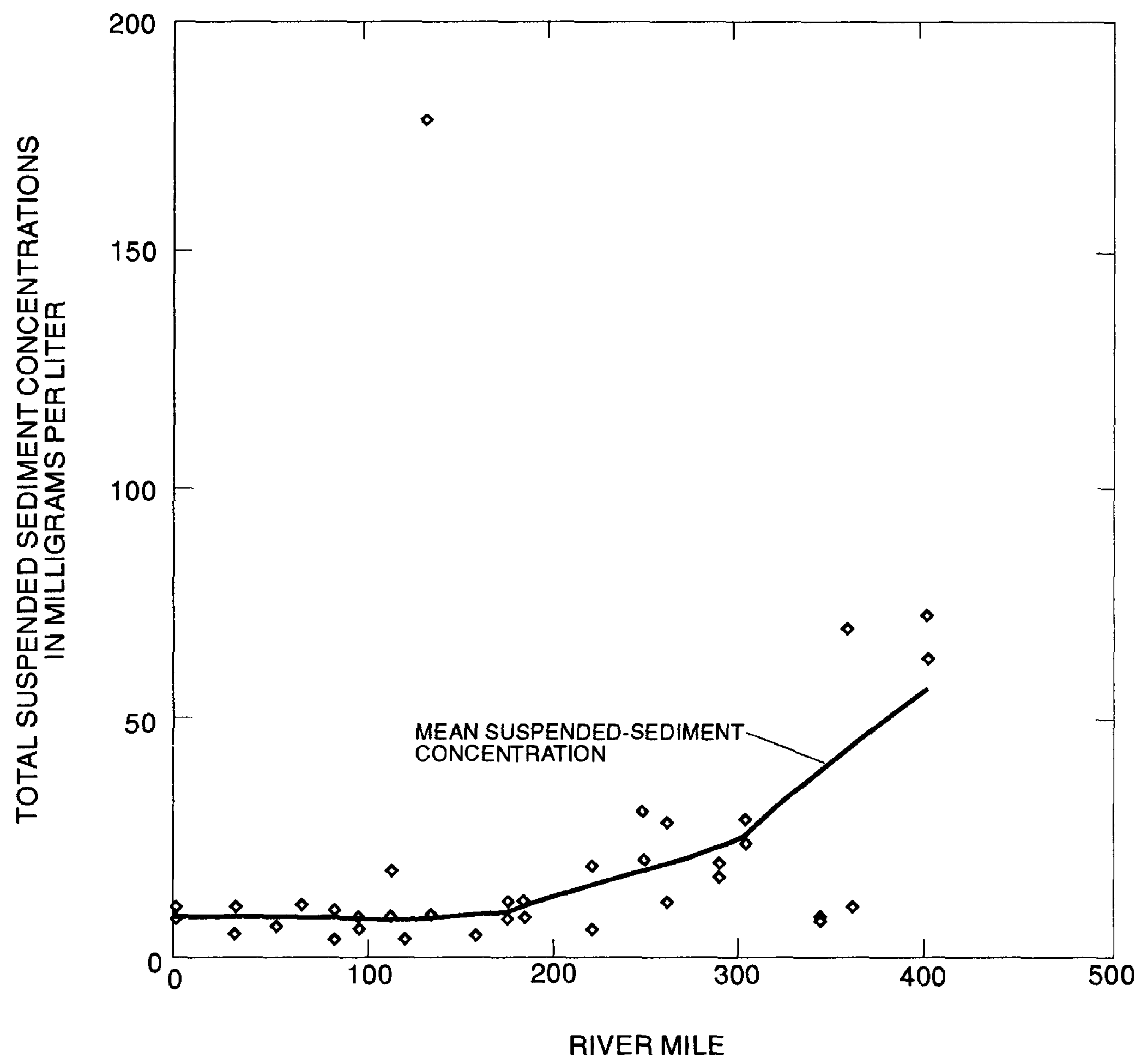

Figure 37. Smoothed mean suspended-sediment concentration in the Kentucky River, April 1987 - March 1990. 


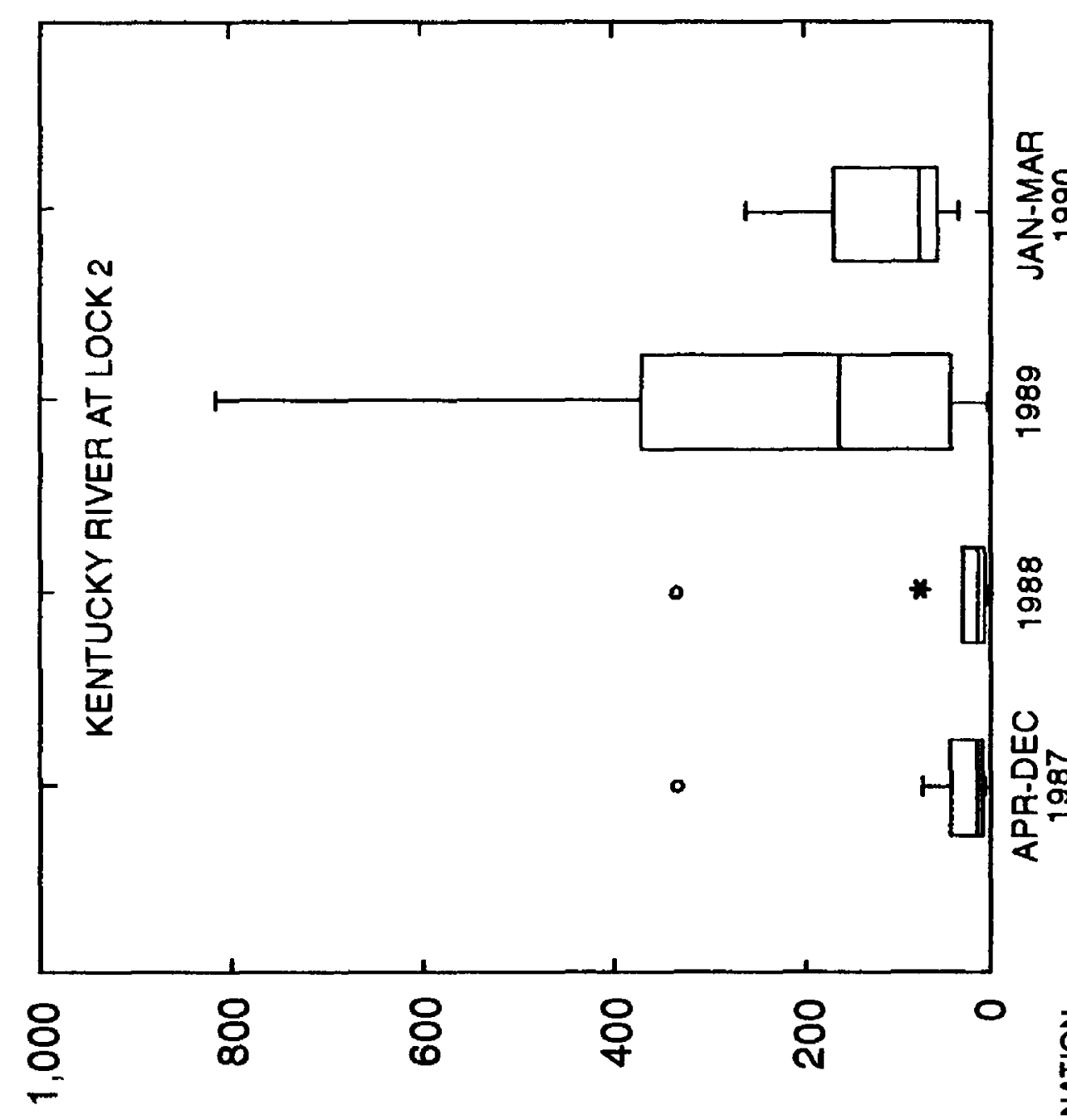

要

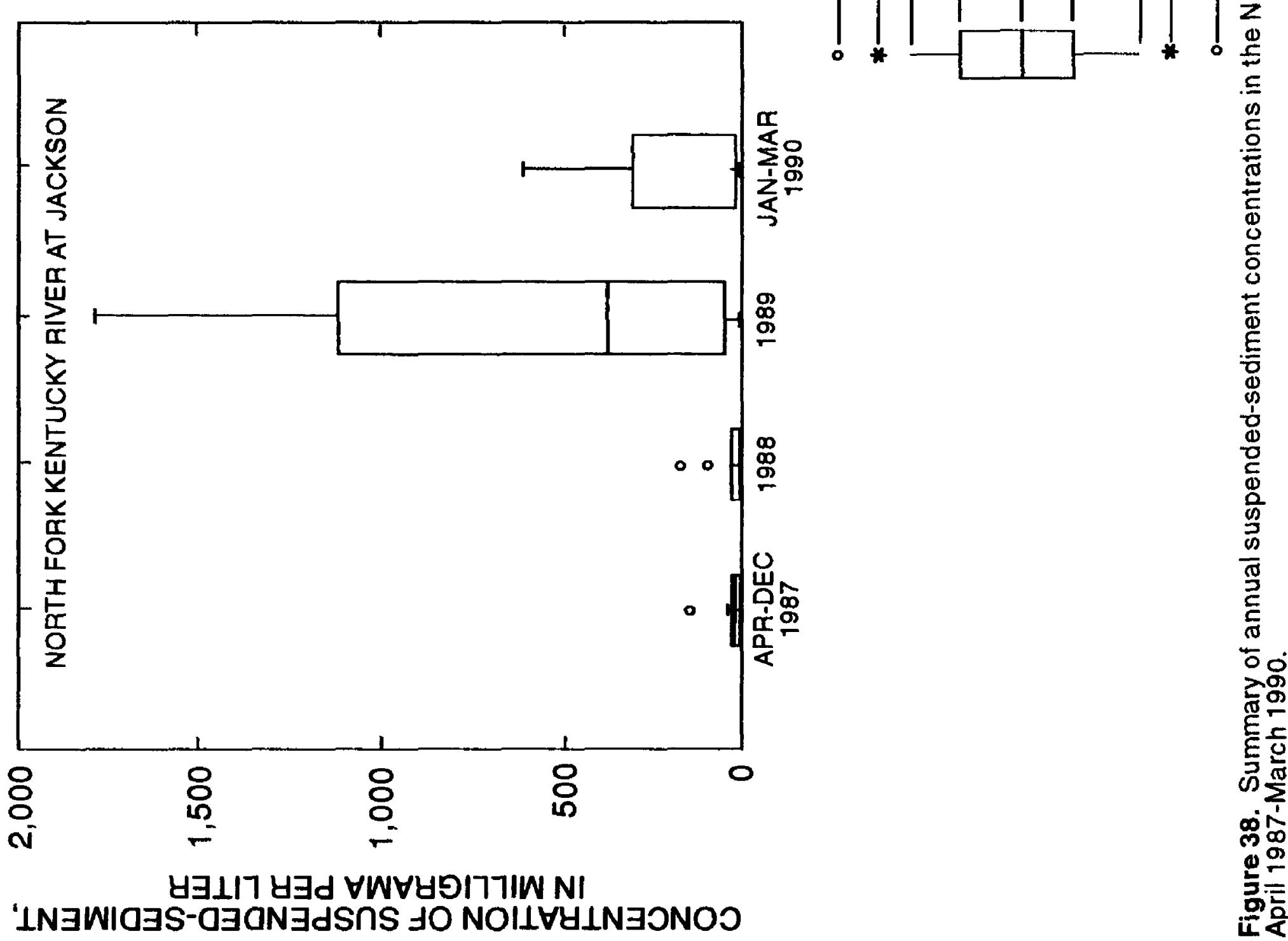




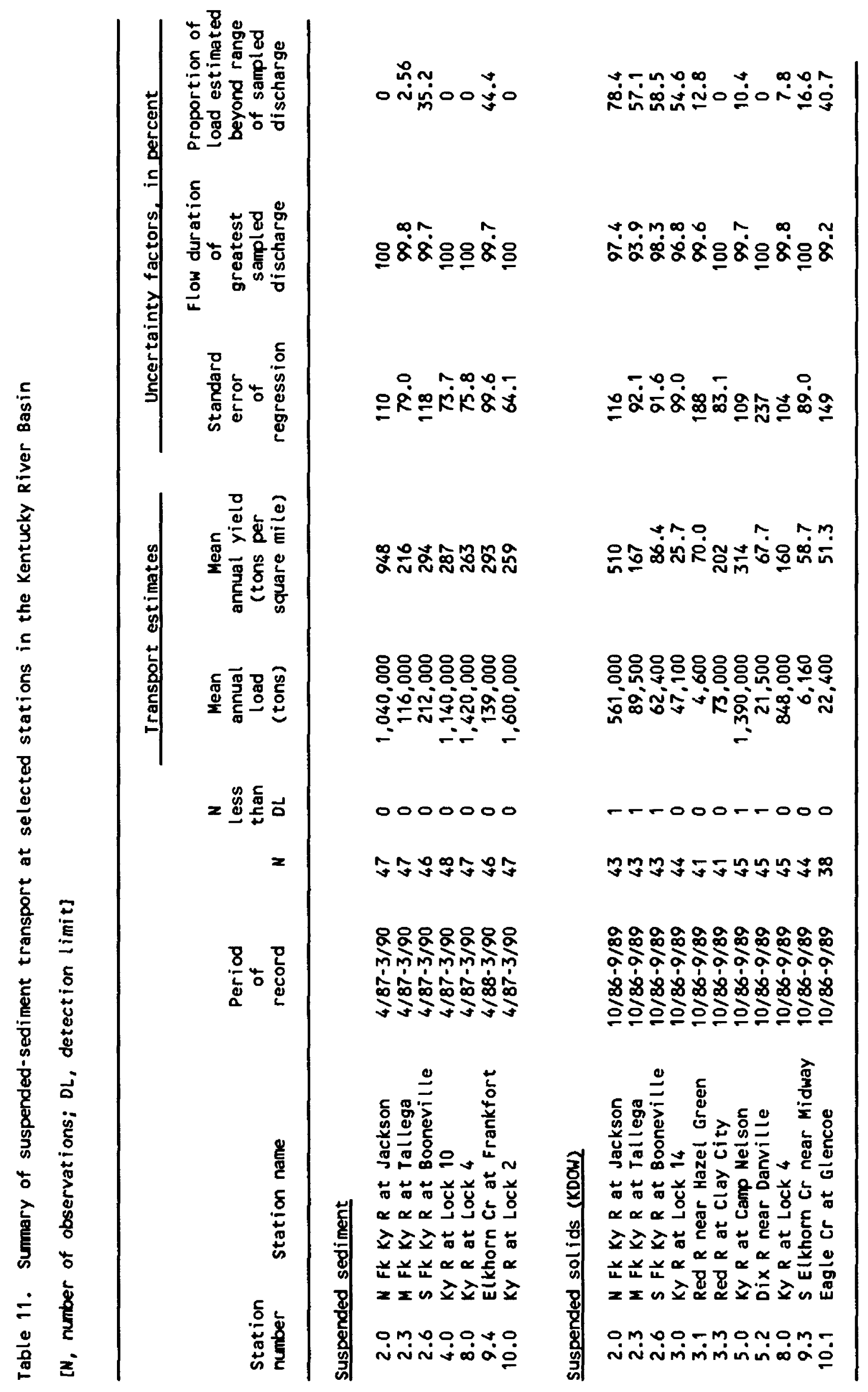




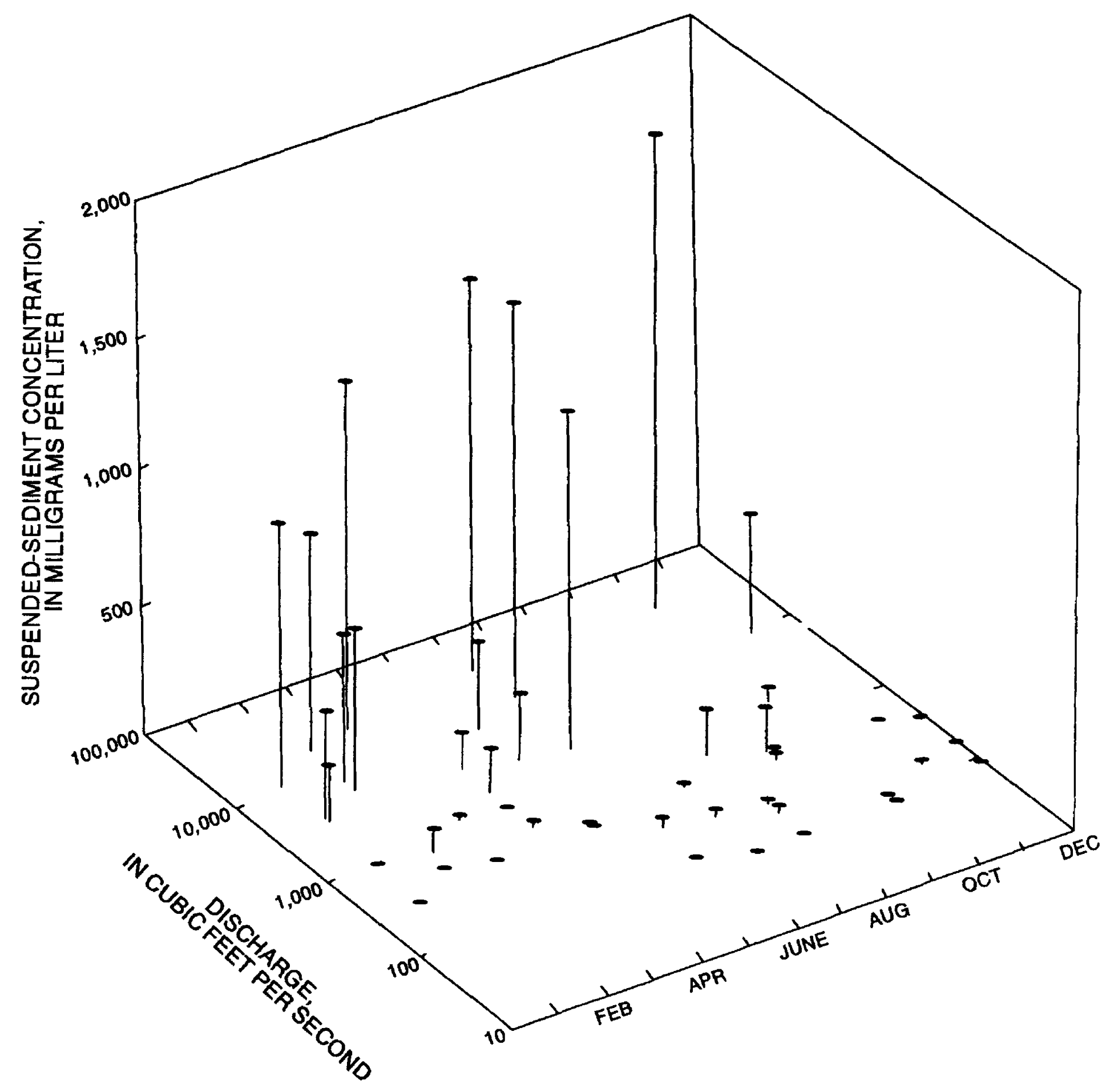

Figure 39. Variations in mean monthly suspended-sediment concentrations and discharge in the North Fork Kentucky River at Jackson, April 1987 - March 1990. 


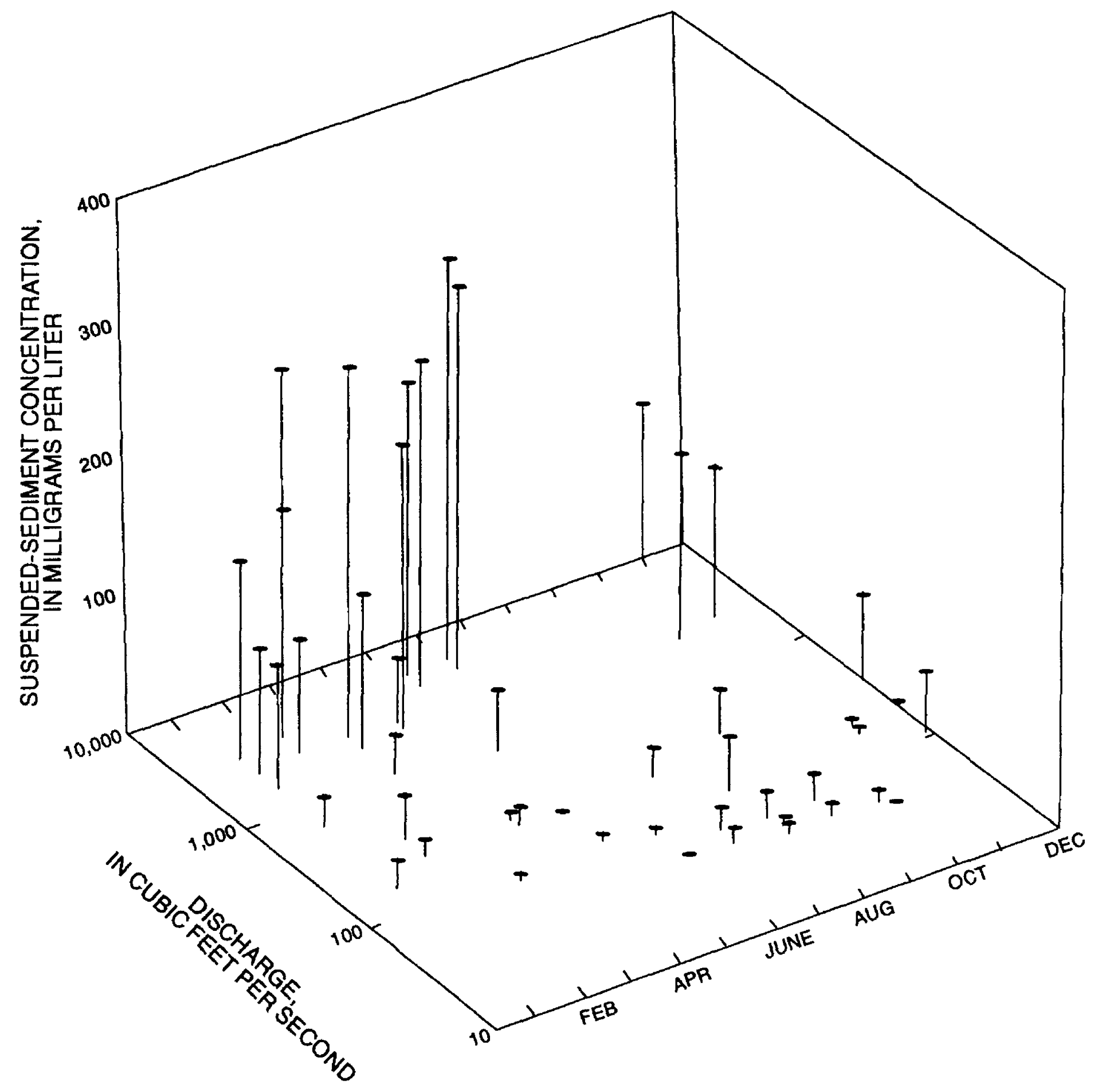

Figure 40. Variations in mean monthly suspended-sediment concentrations and discharge in the Middle Fork Kentucky River at Tallega, April 1987 - March 1990. 


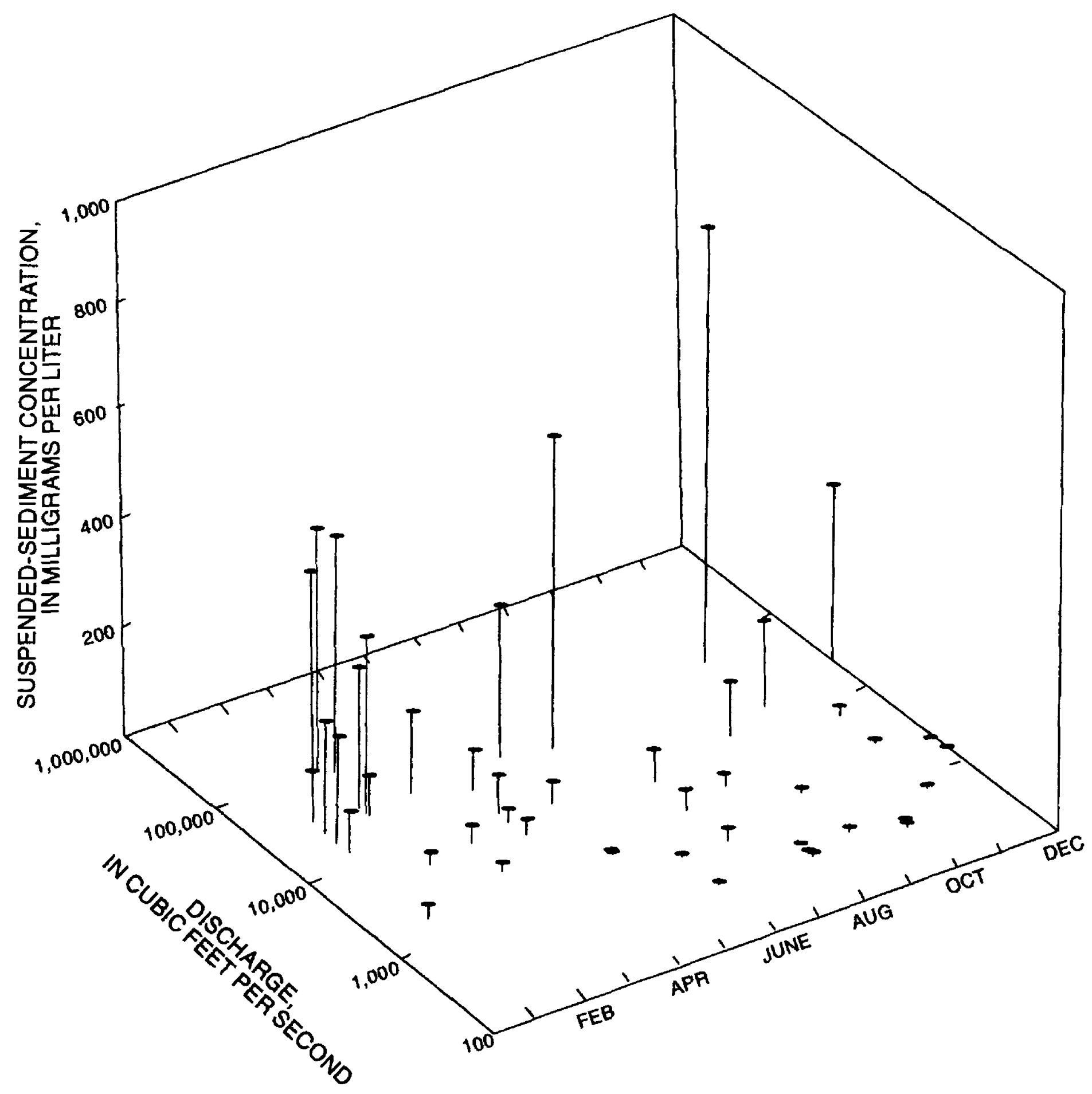

Figure 41. Variations in mean monthly suspended-sediment concentrations and discharge in the Kentucky River at Lock 2, April 1987 - March 1990. 
with the exception of South Fork Kentucky River at Booneville and Elkhorn Creek at Frankfort (data not shown in figs. 39-41). The suspended-sediment concentrations were always lower during July-September, which is typically a low-flow period, than during any other months of the year.

\section{Relation of Suspended-Sediment Concentrations to Other Constituents}

The ability of suspended sediment to adsorb other constituents is well established. However, at the fixed stations in the Kentucky River Basin, significant correlations were not found between total suspended sediment and total concentrations of any of the nutrient forms studied in this basin. At the synoptic sites on the Kentucky River a significant relation was found between mean (August 1987 and August 1988) total phosphorus and suspended sediment above river mile 200 (fig. 42). The relation was weaker and was not significant further downstream where suspended-sediment concentrations were much lower.

\section{Relation of Suspended-Sediment Concentrations During Low Flow to Land Use and Point Sources}

Samples were collected for determination of suspended-sediment concentrations as part of the low-flow synoptic studies in August 1987 and August 1988. No significant correlations between total suspended-sediment concentrations and discharge were found among the synoptic samples in either year or when data from both years were combined, presumably because the range of discharge during this low-flow period was small. No correlations were found between land use and total suspended-sediment concentrations, although the level of resolution of land-use data was perhaps not adequate to reflect differences at the subbasin scale.

However, the correlation between point-source discharges, specifically WWTP's, and suspended-sediment concentrations in streams was significant. The instantaneous effluent loads of total suspended solids from WWTP's in the basin are shown in figure 43. It should be noted that as much as 65 percent of the material reported as total suspended solids in WWTP effluent may be volatile solids (McElroy and Bell, 1974).

Turbidity, which reflects the amount of suspended material in the water column, was measured in both synoptic surveys. Highest turbidities (>50 NTU) were measured in the upper part of the basin (fig. 44), principally in coalmining areas. Turbidities in the range of 5.0 to 50 NTU were common in tributary streams throughout the basin for all land uses. Turbidities in the main stem of the Kentucky River tended to be below 5.0 NTU during both synoptic surveys, which were done during low-flow periods.

\section{Temporal Trends in Suspended-Sediment Concentrations}

Opportunities to discern temporal trends in suspended-sediment concentrations in the Kentucky River main stem were limited by data requirements of Seasonal-Kendall trend tests. The period of record is not 


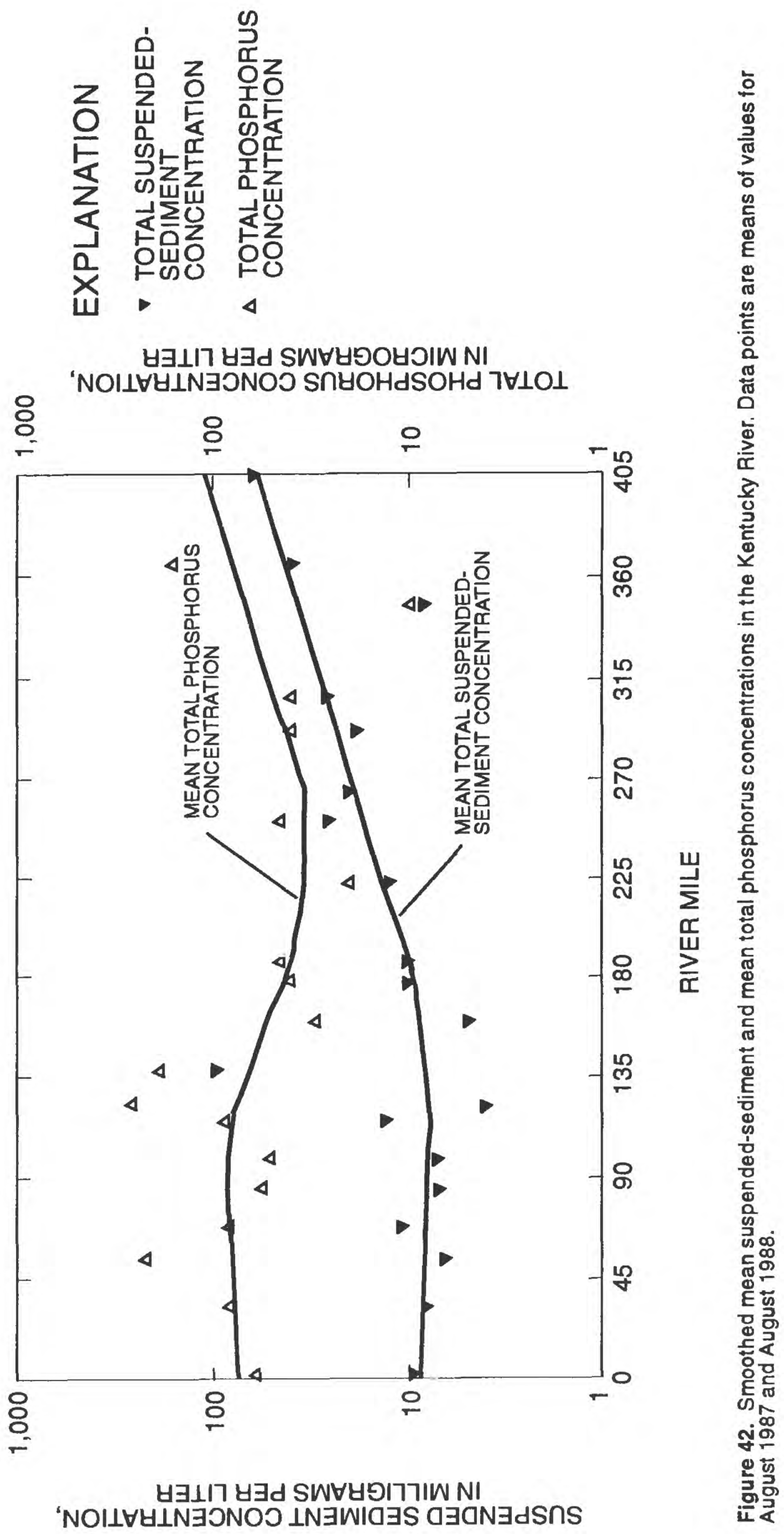



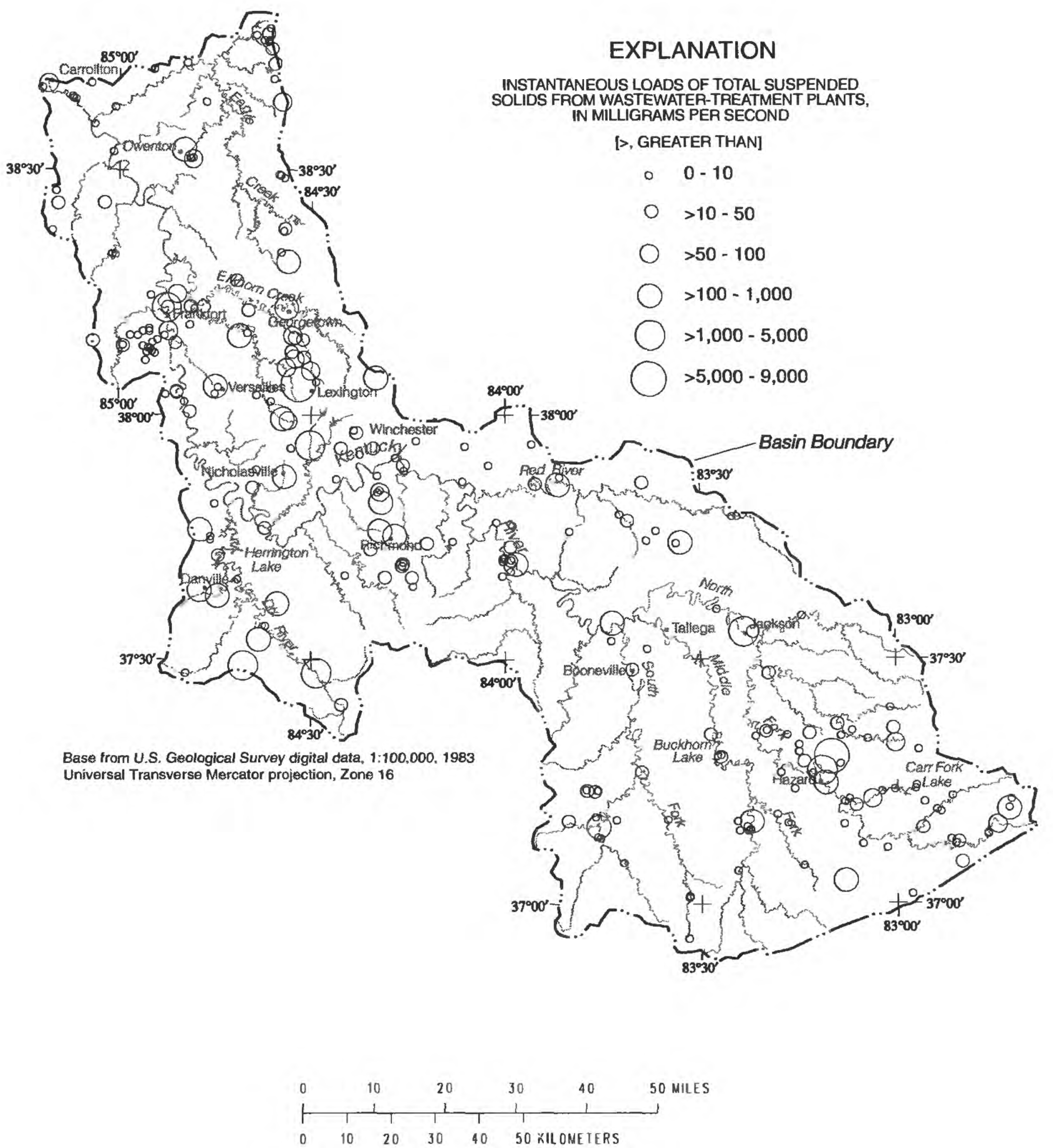

Figure 43. Instantaneous loads of total suspended solids from wastewater-treatment plants in the Kentucky River Basin, August 1991. 


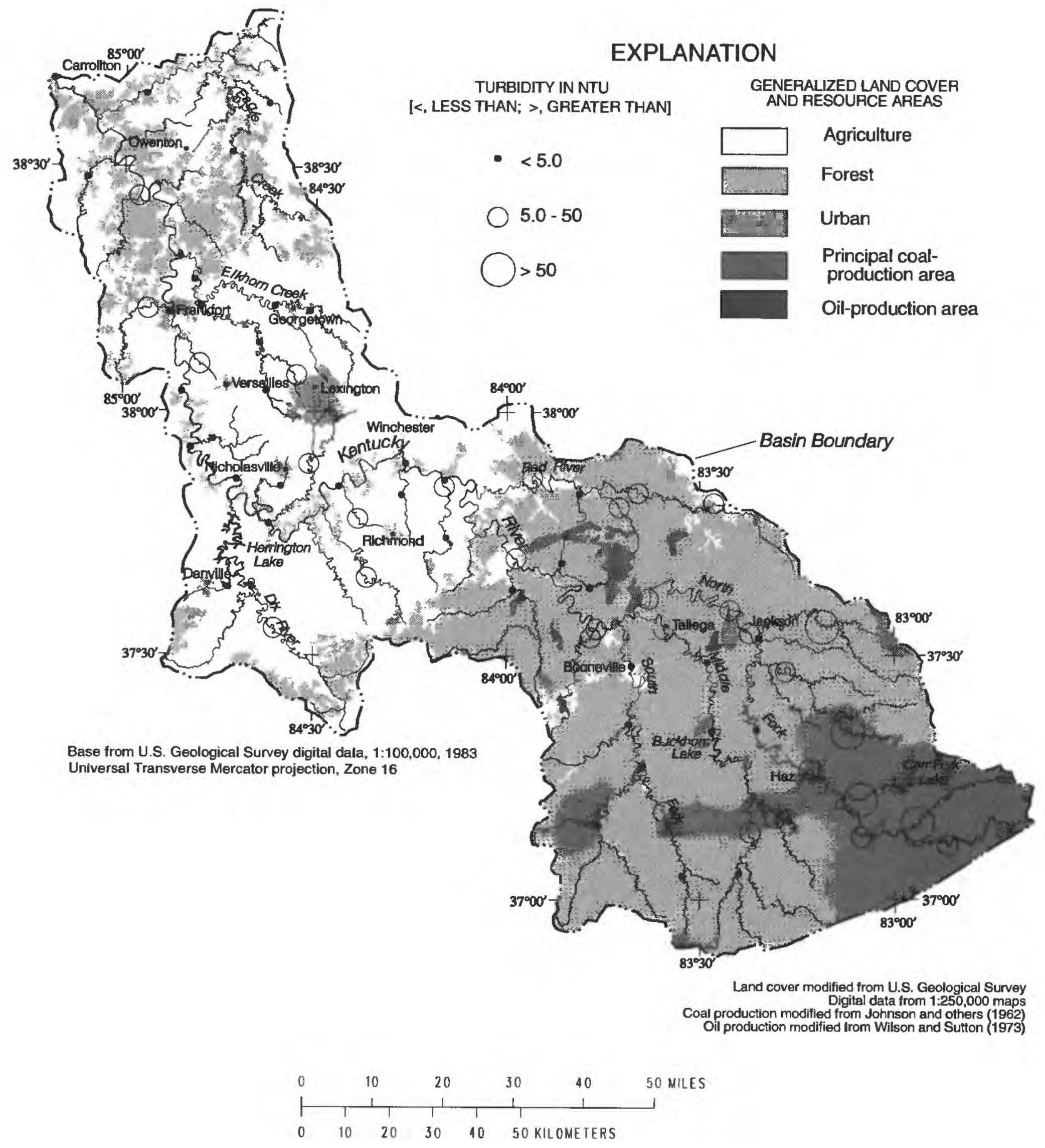

Figure 44. Turbidity in streams of the Kentucky River Basin, August 8-12, 1987. 
sufficient for such analysis at most stations. Results are available, however, for 4 stations where 10 or more years of data were collected. A significant 15-year downward flow-adjusted trend for suspended-sediment concentrations is indicated for the Kentucky River at Lock 2. Similar results were found by use of data from KDOW at Lock 2. No other significant trends in suspended-sediment concentrations were found.

The downward trend at Lock 2 may have resulted from the implementation of best-management practices to reduce soil erosion from surface-mining and agricultural activities in the Kentucky River Basin. Hill (1991) suggests that the implementation of best-management practices in North Carolina may have reduced the sediment yield there by an order of magnitude. However, the suspension of routine lock and dam operations by the U.S. Army Corps of Engineers during the late 1970's and the consequent reduced use of lock facilities by commercial and recreational traffic upstream from Lock 4 may have resulted in increased deposition of sediment upstream from the navigational locks and dams on the Kentucky River and may have affected the observed concentrations over time.

\section{Pesticides}

Water and streambed-sediment samples were analyzed for pesticides at selected sites in the Kentucky River Basin during 1988-90. Results for most samples indicated insecticide (table 12) and herbicide (table 13) concentrations at or below reporting limits.

\section{Spatial Distribution}

The spatial distribution of selected pesticides was assessed by sampling surface-water runoff at 14 sites in 1988 and 1989 . Some sites were sampled only once, whereas others were sampled on 3-10 different dates. Surface water was sampled every 2 months at four of those sites in 1990 (fig. 45). Additional sampling was done during low flows in 1988 to determine the occurrence of organochlorine compounds in streambed sediments at 26 sites in the basin (fig. 46).

\section{Detection in water samples}

Pesticides were detected in water samples in all three years of the study (tables 14 and 15; fig. 47). Diazinon, malathion, and parathion were the most frequently detected organophosphate insecticides, particularly in the Elkhorn Creek Subbasin. In 1988-89, diazinon was found at two sites. Concentrations of diazinon ranged from $0.03 \mu \mathrm{g} / \mathrm{L}$ in Elkhorn Creek at Frankfort to $0.40 \mu \mathrm{g} / \mathrm{L}$ in South E1khorn Creek at Midway. In 1990, diazinon was detected not only in the Elkhorn Creek Subbasin but also in the Kentucky River at Lock 10 and Lock 2, in the Red River at Clay City, and in the Eagle Creek Subbasin (table 15). Diazinon is widely used for insect control on tobacco, fruits, vegetables, pasture, grasslands, and ornamentals. Diazinon has a moderately rapid rate of degradation when exposed to sunlight and low mobility in the soil (U.S. Environmental Protection Agency, 1991). 
Table 12. Incidence of detection of insecticides in water and streambed-sediment samples in the Kentucky River Basin, 1988-90 [ $\mu \mathrm{g} / \mathrm{kg}$, micrograms per kilogram; $\mu \mathrm{g} / \mathrm{L}$, micrograms per liter]

\begin{tabular}{|c|c|c|c|c|}
\hline Common name & \multicolumn{2}{|c|}{ Reporting limit } & $\begin{array}{c}\text { Number } \\
\text { of samples }\end{array}$ & $\begin{array}{l}\text { Incidence } \\
\text { of detection, } \\
\text { in percent }\end{array}$ \\
\hline Aldrin & 2.5 & $\mu \mathrm{g} / \mathrm{kg}$ & 25 & 16 \\
\hline Arochlor 1242 & 25.0 & $\mu \mathrm{g} / \mathrm{kg}$ & 25 & 8 \\
\hline Arochlor 1260 & 25.0 & $\mu \mathrm{g} / \mathrm{kg}$ & 25 & 4 \\
\hline BHC-Alpha isomer & 2.5 & $\mu \mathrm{g} / \mathrm{kg}$ & 25 & 4 \\
\hline Chlordane & .25 & $\mu \mathrm{g} / \mathrm{kg}$ & 24 & 25 \\
\hline Chlorpyrifos & .01 & $\mu \mathrm{g} / \mathrm{L}$ & 6 & 9 \\
\hline DDE & 2.5 & $\mu \mathrm{g} / \mathrm{kg}$ & 23 & 9 \\
\hline DDT & 2.5 & $\mu \mathrm{g} / \mathrm{kg}$ & 25 & 8 \\
\hline Diazinon & .01 & $\mu \mathrm{g} / \mathrm{L}$ & 30 & 77 \\
\hline Dieldrin & 2.5 & $\mu \mathrm{g} / \mathrm{kg}$ & 25 & 4 \\
\hline Endosulfan & .5 & $\mu \mathrm{g} / \mathrm{kg}$ & 25 & 8 \\
\hline Endrin & 2.5 & $\mu \mathrm{g} / \mathrm{kg}$ & 25 & 8 \\
\hline Heptachlor & 2.5 & $\mu \mathrm{g} / \mathrm{kg}$ & 25 & 16 \\
\hline Heptachlor epoxide & 2.5 & $\mu \mathrm{g} / \mathrm{kg}$ & 25 & 36 \\
\hline Lindane & 2.5 & $\mu \mathrm{g} / \mathrm{kg}$ & 24 & 4 \\
\hline Malathion & .01 & $\mu \mathrm{g} / \mathrm{L}$ & 30 & 30 \\
\hline Parathion & .01 & $\mu \mathrm{g} / \mathrm{L}$ & 30 & 13 \\
\hline
\end{tabular}


Table 13. Incidence of detection of herbicides in water samples in the Kentucky River Basin, 1988-90

\begin{tabular}{lccc}
\hline Common name & $\begin{array}{c}\text { Reporting limit, } \\
\text { in micrograms } \\
\text { per liter }\end{array}$ & $\begin{array}{c}\text { Number } \\
\text { of samples }\end{array}$ & $\begin{array}{c}\text { Incidence } \\
\text { of detection, } \\
\text { in percent }\end{array}$ \\
\hline Alachlor & 0.1 & 28 & 14 \\
Atrazine & .1 & 27 & 44 \\
Cyanazine & .1 & 28 & 7 \\
2,4-D & 20.0 & 29 & 45 \\
Dicamba & .01 & 29 & 14 \\
Metolachlor & .1 & 29 & 3 \\
Metribuzin & .1 & 29 & 3 \\
Picloram & .01 & 28 & 4 \\
Prometon & .1 & 29 & 34 \\
Simazine & .1 & 28 & 36 \\
\hline
\end{tabular}




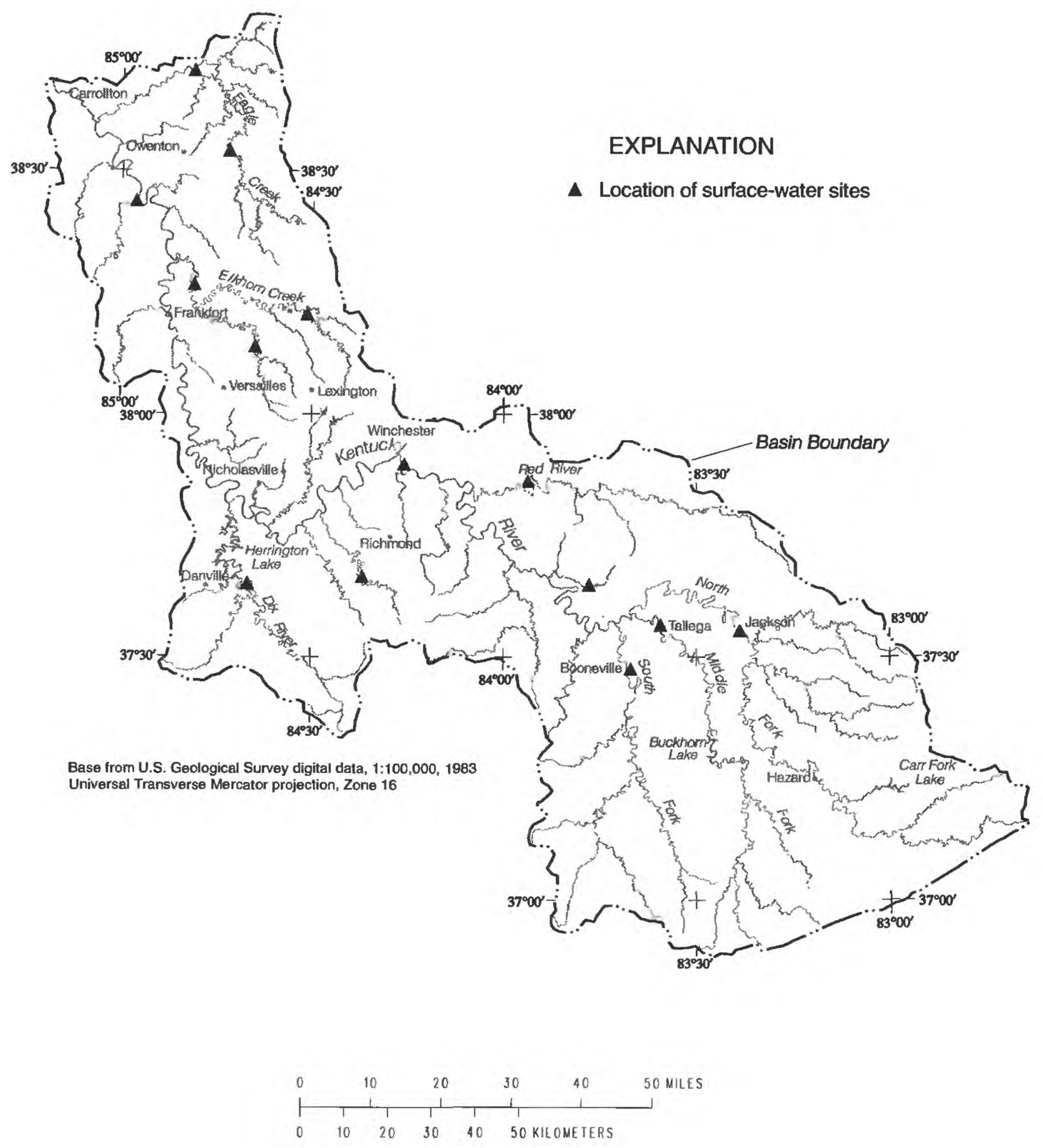

Figure 45. Surface-water sampling sites for pesticides in the Kentucky River Basin, 1988-90. 


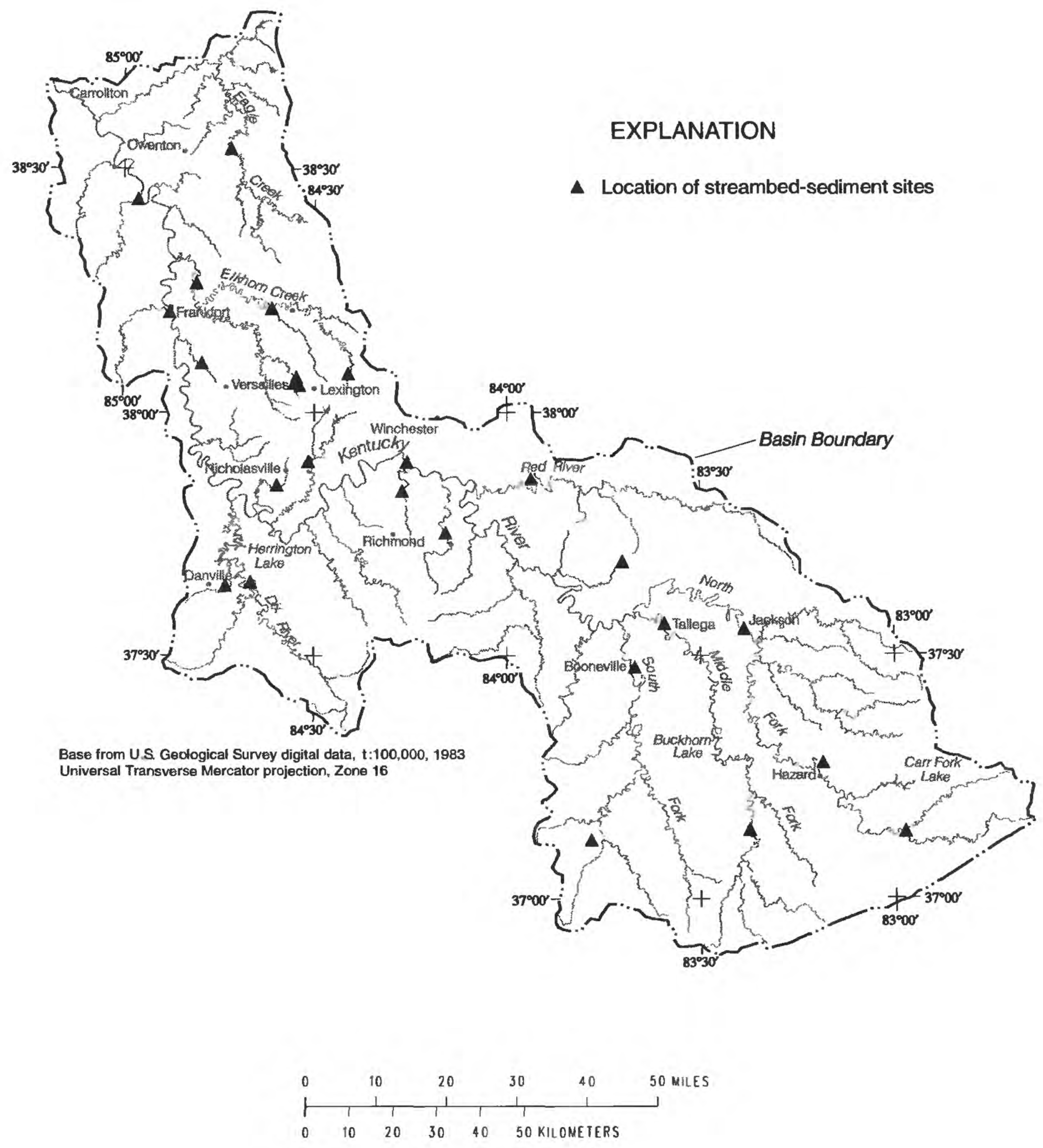

Figure 46. Streambed-sediment sampling sites for pesticides in the Kentucky River Basin, 1988-90. 
Table 14. Concentrations of pesticides detected in water samples from streams in the Kentucky River Basin, 1988-89

\author{
Pesticide \\ and sample site
}

Concentration, in micrograms

Date per liter

\section{Organophosphate insecticides}

Diazinon

South Elkhorn Creek near Midway

$\begin{array}{lr}11 / 05 / 88 & 0.34 \\ 02 / 13 / 89 & .10 \\ 06 / 06 / 89 & .07 \\ 09 / 12 / 89 & .40 \\ 11 / 05 / 88 & .12 \\ 06 / 06 / 89 & .03\end{array}$

Malathion

South Elkhorn Creek near Midway

$06 / 06 / 89$

$09 / 12 / 89$

$\mathrm{a} .01$

Parathion

South Elkhorn Creek near Midway

$09 / 12 / 89$

a .11

\section{Herbicides}

Alachlor

North Elkhorn Creek near Georgetown

$02 / 13 / 89$

1.2

South Elkhorn Creek near Midway

$02 / 15 / 89$

$06 / 06 / 89$

Eagle Creek at Glencoe

$06 / 06 / 89$

.2

.3

.1

Atrazine

North Fork Kentucky River at Jackson $06 / 15 / 8$

.1

Middle Fork Kentucky River at Tallega

$06 / 16 / 89$

South Fork Kentucky River at Booneville

Red River at Clay City

$06 / 15 / 89$

$09 / 06 / 89$

$06 / 17 / 89$

Kentucky River at Lock 10

$02 / 13 / 89$

$06 / 06 / 89$

South Elkhorn Creek near Midway

Elkhorn Creek at Frankfort

Eagle Creek at Glencoe

$06 / 06 / 89$

$06 / 06 / 89$

$06 / 06 / 89$

Cyanazine

Red River at Clay City

$09 / 06 / 89$

$06 / 06 / 89$

.1

.2 
Table 14. Concentrations of pesticides detected in water samples from streams in the Kentucky River Basin, 1988-89--Continued

\begin{tabular}{|c|c|c|}
\hline $\begin{array}{l}\text { Pesticide } \\
\text { and sample site }\end{array}$ & Date & $\begin{array}{c}\text { Concentration, } \\
\text { in micrograms } \\
\text { per liter }\end{array}$ \\
\hline \multicolumn{3}{|l|}{$2,4-D$} \\
\hline North Elkhorn Creek near Georgetown & $06 / 06 / 89$ & 0.17 \\
\hline South Elkhorn Creek near Midway & $06 / 06 / 89$ & .47 \\
\hline \multirow{2}{*}{ E1khorn Creek at Frankfort } & $11 / 05 / 88$ & .02 \\
\hline & $06 / 06 / 89$ & .44 \\
\hline \multicolumn{3}{|l|}{ Dicamba } \\
\hline Big Sinking Creek near Crystal & $02 / 15 / 89$ & .4 \\
\hline Elkhorn Creek at Frankfort & $11 / 05 / 88$ & .02 \\
\hline \multicolumn{3}{|l|}{ Metolachlor } \\
\hline North Elkhorn Creek near Georgetown & $02 / 13 / 89$ & .9 \\
\hline \multicolumn{3}{|l|}{ Metribuzin } \\
\hline North Elkhorn Creek near Georgetown & $02 / 13 / 89$ & 1.1 \\
\hline \multicolumn{3}{|l|}{ Picloram } \\
\hline South E1khorn Creek near Midway & $11 / 05 / 88$ & .02 \\
\hline \multicolumn{3}{|l|}{ Prometon } \\
\hline North E1khorn Creek near Georgetown & $11 / 05 / 88$ & .2 \\
\hline Elkhorn Creek at Frankfort & $06 / 06 / 89$ & .1 \\
\hline \multirow[t]{2}{*}{ South Elkhorn Creek near Midway } & $06 / 06 / 89$ & .1 \\
\hline & $09 / 12 / 89$ & .1 \\
\hline \multicolumn{3}{|l|}{ Simazine } \\
\hline South Fork Kentucky River at Booneville & $06 / 15 / 89$ & .1 \\
\hline Red River at Clay City & $06 / 09 / 89$ & .1 \\
\hline \multirow[t]{2}{*}{ North Elkhorn Creek near Georgetown } & $02 / 13 / 89$ & .6 \\
\hline & $06 / 06 / 89$ & 4.5 \\
\hline South Elkhorn Creek near Midway & $06 / 06 / 89$ & .2 \\
\hline Elkhorn Creek at Frankfort & $06 / 06 / 89$ & .2 \\
\hline Eagle Creek at Glencoe & $06 / 06 / 89$ & .1 \\
\hline
\end{tabular}

${ }^{a}$ Concentrations exceed the Maximum Contaminant Levels for acute and (or) chronic aquatic life criteria (U.S. Environmental Protection Agency, 1992).

${ }^{b}$ Concentrations exceed the Maximum Contaminant Levels for drinking water (U.S. Environmental Protection Agency, 1991). 
Table 15. Concentrations of pesticides detected in water samples from streams in the Kentucky River Basin, 1990

\begin{tabular}{|c|c|c|}
\hline $\begin{array}{l}\text { Pesticide } \\
\text { and sample site }\end{array}$ & Date & $\begin{array}{c}\text { Concentration, } \\
\text { in micrograms } \\
\text { per liter }\end{array}$ \\
\hline
\end{tabular}

\section{Organophosphate insecticides}

Chlorpyrifos

South Elkhorn Creek near Midway

$08 / 29 / 90$

0.02

Diazinon

Red River at Clay City

Kentucky River at Lock 10

$07 / 12 / 90 \quad .01$

North Elkhorn Creek near Georgetown

$07 / 12 / 90$

.02

$01 / 04 / 90$

.07

South Elkhorn Creek near Midway

$08 / 29 / 90$

.02

$01 / 04 / 90$

.03

E1khorn Creek at Frankfort

Kentucky River at Lock 2

$08 / 29 / 90$

.23

$08 / 29 / 90$

.06

Eagle Creek at Lusbys Mill

$07 / 13 / 90$

.01

$08 / 29 / 90$

.01

Malathion

North Elkhorn Creek near Georgetown

$01 / 04 / 90$

.03

$08 / 29 / 90$

.03

South Elkhorn Creek near Midway

$08 / 29 / 90$

.01

Parathion

North Elkhorn Creek near Georgetown

$01 / 04 / 90$

a. 08

\section{Herbicides}

Atrazine

Red River at Clay City

Kentucky River at Lock 10

North Elkhorn Creek near Georgetown

Kentucky River at Lock 2

$07 / 12 / 90$

$07 / 12 / 90$

.4

$08 / 29 / 90$

.3

$07 / 13 / 90$

.1

.3

$2,4-D$

Red River at Clay City

Kentucky River at Lock 10

$07 / 12 / 90$

.69

$07 / 12 / 90$

.09

North Elkhorn Creek near Georgetown

$08 / 29 / 90$

.05

South Elkhorn Creek near Midway

$08 / 29 / 90$

.47

Elkhorn Creek at Frankfort

$08 / 29 / 90$

.13

Kentucky River at Lock 2

$07 / 13 / 90$

.05

Eagle Creek at Lusbys Mill

$08 / 29 / 90$

.03 
Table 15. Concentrations of pesticides detected in water samples from streams in the Kentucky River Basin, 1990--Continued

\begin{tabular}{clc}
\hline $\begin{array}{c}\text { Pesticide } \\
\text { and sample site }\end{array}$ & $\begin{array}{c}\text { Concentration, } \\
\text { in micrograms } \\
\text { per 1iter }\end{array}$ \\
\hline Dicamba & Date & 0.03 \\
South Elkhorn Creek near Midway & $08 / 29 / 90$ & \\
Prometon & & .1 \\
North Elkhorn Creek near Georgetown & $08 / 29 / 90$ & .1 \\
South Elkhorn Creek near Midway & $01 / 04 / 90$ & .2 \\
Elkhorn Creek at Frankfort & $08 / 29 / 90$ & .1 \\
Simazine River at Clay City & $08 / 29 / 90$ & .2 \\
Red River at Lock 10 & & .1 \\
Kentucky River & $07 / 12 / 90$ & \\
Kentucky River at Lock 2 & $07 / 12 / 90$ & \\
& $07 / 13 / 90$ & \\
\hline
\end{tabular}

${ }^{a}$ Concentrations exceed Maximum Contaminant Levels for acute and (or) chronic aquatic life criteria (U.S. Environmental Protection Agency, 1992). 


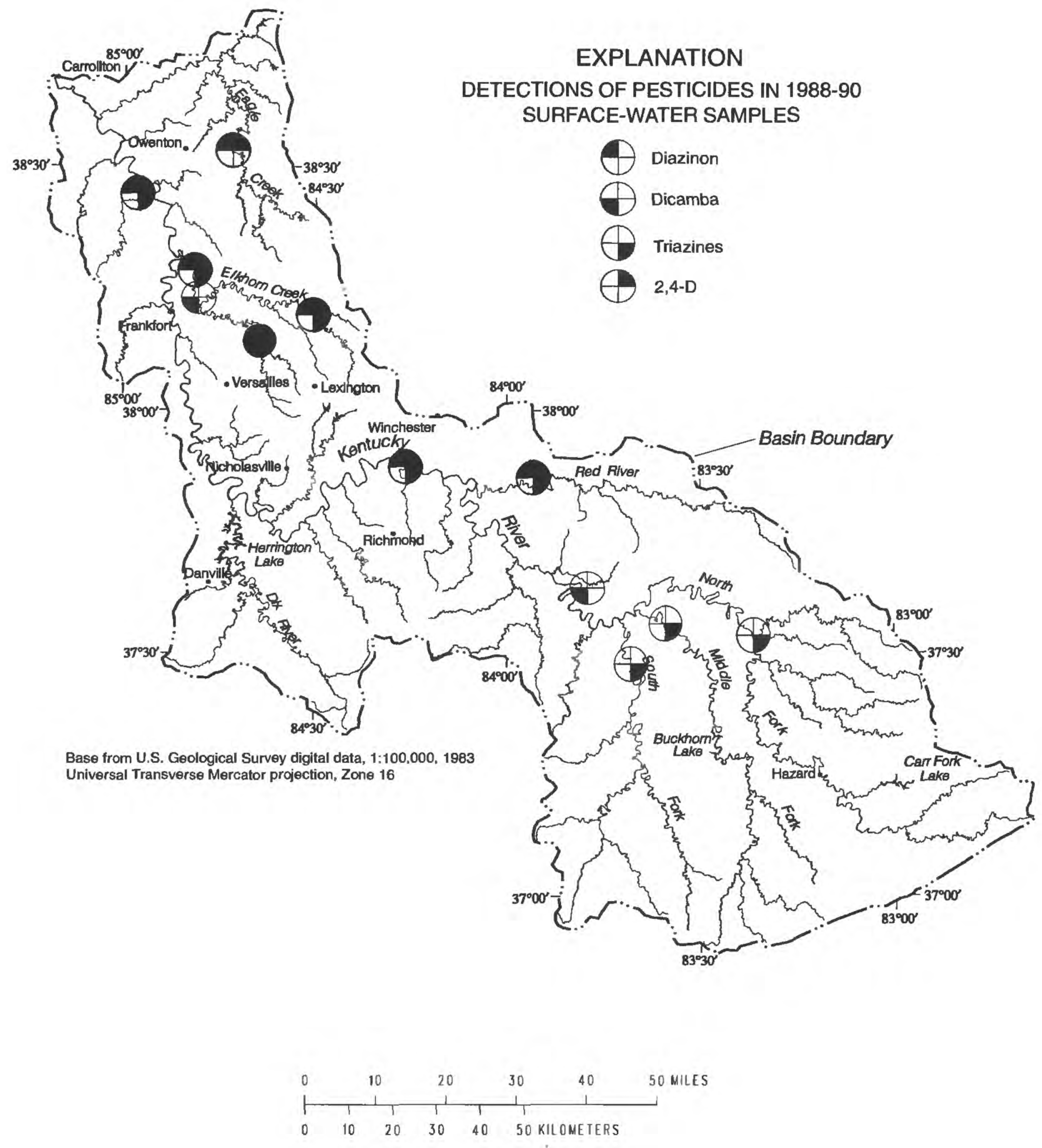

Figure 47. Detections of pesticides in surface-water samples in the Kentucky River Basin, 1988-90. 
Malathion and parathion were often detected in the Elkhorn Creek Subbasin in all 3 years; concentrations ranged from 0.01 to $0.14 \mu \mathrm{g} / \mathrm{L}$ and 0.08 to $0.11 \mu \mathrm{g} / \mathrm{L}$, respectively. These compounds are relatively short lived in the environment (Biggar and Seiber, 1987), but they are used widely in agriculture, home gardens, and mosquito-abatement programs. Chlorpyrifos, which is used for house parasites and some insects of crops (including corn and tobacco), was detected only in 1990 in South Elkhorn Creek at Midway $(0.02 \mu \mathrm{g} / \mathrm{L})$. Organochlorine insecticides were not detected in water samples in this study. The very low solubility of these compounds in water makes it unlikely that they would be present at levels above the reporting limits (Butler, 1987).

Several herbicides were detected in surface-water samples in the basin (fig. 47), principally in 1989 (tables 14 and 15). Among the triazine herbicides were atrazine, cyanizine, simazine, and metribuzin. Atrazine was found throughout the basin, including the North, Middle, and South Forks of the Kentucky River. Atrazine is the most heavily used herbicide in the United States and is extensively used in the Kentucky River Basin for selective weed control in corn production. Atrazine is moderately to highly mobile in soils ranging from clay to gravelly sand (D.A. Goolsby, U.S. Geological Survey, written commun., 1992), and frequent detections in surface-water samples would be expected, particularly after seasonal application to crops. Numerous detections of atrazine were recorded in the Elkhorn Creek Subbasin. Although concentrations rarely exceeded $0.5 \mu \mathrm{g} / \mathrm{L}$, water samples collected in June 1989 from North Elkhorn Creek near Georgetown had unusually high concentrations of atrazine $(16.0 \mu \mathrm{g} / \mathrm{L})$ and simazine $(4.5 \mu \mathrm{g} / \mathrm{L})$. These high concentrations are similar to those found by Goolsby and others (1991) in the Mississippi River. Goolsby and others (1991) reported atrazine residues throughout the year; however, the highest atrazine concentrations occurred in May and June, presumably after postapplication rainfall flushing in late spring and early summer.

Prometon, another triazine herbicide approved for use on perennial broadleaf weeds and grasses, was found at several sites in the Elkhorn Creek Basin. Prometon is the only herbicide commonly used on tobacco that was detected in this study.

The herbicide 2,4-D was present in multiple samples collected in the Elkhorn Creek Subbasin, as well as in samples from the Red River, the Kentucky River at Locks 10 and 2, and in Eagle Creek at Lusbys Mill. Although 2,4-D is widely used to control broadleaf weeds in cereal crops, such as corn, wheat, alfalfa, and soybeans, it degrades within 1 to 4 weeks under field conditions (Howard, 1991).

Alachlor and metolachlor, which are significantly less persistent than atrazine (Perry, 1991; Thurman and others, 1992), were found in Elkhorn Creek and Eagle Creek in 1989. Alachor and metolachlor are used on corn and soybeans; the latter is mobile in soil and available in surface-water runoff (U.S. Environmental Protection Agency, 1991). Dicamba was found in the Elkhorn Creek Subbasin at low concentrations $(0.02-0.03 \mu \mathrm{g} / \mathrm{L})$, and in $\mathrm{Big}$ Sinking Creek at a higher concentration $(0.4 \mu \mathrm{g} / \mathrm{L})$. Dicamba is used to control broadleaf weeds in field and silage corn, as well as on noncrop areas such as fence rows, roadways, and wastelands. Picloram, a restricted-use 
herbicide used on grassland and rights-of-way for powerlines, was found at only one site, South Elkhorn Creek near Midway. Metribuzin, used on alfalfa and soybeans, was found in only one sample, from North Elkhorn Creek near Georgetown.

The concentrations of pesticides seldom exceeded the established Maximum Contaminant Levels (MCL's) in the USEPA Drinking Water Health Advisory (U.S. Environmental Protection Agency, 1991) and acute and chronic Aquatic Life Criteria (U.S. Environmental Protection Agency, 1986) (tables 14 and 15). Malathion and parathion were found in South Elkhorn Creek near Midway at concentrations exceeding MCL's for aquatic life, whereas atrazine was found at concentrations exceeding MCL's for drinking water in North Elkhorn Creek near Georgetown. Concentrations of atrazine may periodically be sufficiently high to affect the biotic integrity of streams in the Kentucky River Basin, as indicated in studies of direct and indirect effects of this herbicide on stream biota (deNoyelles and others, 1982; Dewey, 1986; Veber and others, 1981).

\section{Accumulation in streambed sediments}

Many organic compounds have a low solubility in water and tend to adsorb to particulate matter. Streambed sediments in the Kentucky River Basin were analyzed for pesticides at 25 sites in November 1988 (table 16; fig. 48).

Organochlorine insecticides were detected in streambed sediments at numerous sites in the basin. These compounds account for less than 10 percent of all insecticides used in the United States, but they are highly persistent and tend to remain in the environment long after their initial application. The cyclodiene insecticides--including aldrin, chlordane, dieldrin, endrin, endosulfan, heptachlor, heptachlor epoxide, and lindane--were commonly detected, particularly in the lower end of the basin (fig. 48). Chlordane was found at concentrations from 59.4 to $269.0 \mu \mathrm{g} / \mathrm{kg}$ in Hickman Creek, Town Fork, Town Branch, Glenns Creek, and North Elkhorn Creek (table 16). Although chlordane is no longer used for termite control, it is highly persistent in the environment and is fairly common near residential or urban land use. Heptachlor was detected at eight sites, principally in the lower end of the basin. Concentrations of heptachlor, a restricted-use insecticide used principally for termite control, ranged from 1.1 to $33.8 \mu \mathrm{g} / \mathrm{kg}$ (table 16). Endosulfan was detected at only two sites in the basin in 1988; however, the agricultural use of endosulfan increased in the state by about 65 percent from 1990 to 1992 (University of Kentucky, 1993b), and detections in streambedsediment samples in agricultural areas may also increase.

The occurrence of DDT in the Kentucky River Basin is notable because DDT has been banned in the United States since 1973. It was present in two streambed-sediment samples at concentrations ranging from 3.8 to $8.8 \mu \mathrm{g} / \mathrm{kg}$ (table 16). DDE, a degradation product of DDT, was found in four samples at concentrations ranging from 2.7 to $55.9 \mu \mathrm{g} / \mathrm{kg}$. Both of these compounds are relatively insoluble in water and tend to associate with streambed sediments, where they can remain for years. 
Table 16. Maximum concentrations of pesticides detected in streambedsediment samples from streams in the Kentucky River Basin, 1988

Pesticide
and sample site $\quad \begin{gathered}\text { Concentration, } \\ \text { in micrograms } \\ \text { per kilogram }\end{gathered}$

\section{Organochlorine insecticides}

Aldrin

North Fork Kentucky River at Jackson $11 / 15 / 88$

3.3

South Fork Kentucky River at Booneville 11/15/88

2.0

Horse Creek near Hima

$11 / 14 / 88$

22.0

Eagle Creek at Lusbys Mill

$11 / 16 / 88$

3.5

Arochlor 1242

South Fork Kentucky River at Booneville 11/15/88

Eagle Creek at Lusbys Mill

$11 / 16 / 88$

46.2

57.8

Arochlor 1260

Hickman Creek near Mills

$11 / 16 / 88$

130.0

BHC-Alpha isomer

South Fork Kentucky River at Booneville 11/15/88 .9

Chlordane

Hickman Creek near Mills

$11 / 16 / 88$

$11 / 16 / 88$

$11 / 16 / 88$

$11 / 15 / 88$

$11 / 16 / 88$

59.4

Town Fork near Nicholasville

Glenns Creek near Versailles

North Elkhorn Creek at Bryan Station

Town Branch near Lexington

$11 / 15 / 88$

$11 / 16 / 88$

$11 / 17 / 88$

84.8

96.6

269.0

DDE

Kentucky River at Lock 10

Town Branch near Lexington

Kentucky River at Lock 2

$11 / 16 / 88$

97.0

Eagle Creek at Lusbys Mill

DDT

North Fork Kentucky River at Blackey 11/14/88

$11 / 14 / 88$

3.8

Horse Creek near Hima

$11 / 16 / 88$

16.9

Glenns Creek near Versailles

10.4

55.9

8.9

2.7

Dieldrin

sulfan

Endosulfan

Horse Creek near Hima

Eagle Creek at Lusbys Mill

$11 / 14 / 88$

3.8

$11 / 16 / 88$

1.9 
Table 16. Maximum concentrations of pesticides detected in streambedsediment samples from streams in the Kentucky River Basin, 1988--Continued

\begin{tabular}{ccc}
\hline $\begin{array}{c}\text { Pesticide } \\
\text { and sample site }\end{array}$ & $\begin{array}{c}\text { Concentration, } \\
\text { in micrograms } \\
\text { per kilogram }\end{array}$ \\
\hline $\begin{array}{c}\text { Endrin } \\
\text { Kentucky River at Lock 10 }\end{array}$ & 12.7 \\
Town Branch near Lexington & $11 / 15 / 88$ & \\
Heptachlor & $11 / 16 / 88$ & \\
Lotts Creek near Darfork & & 1.1 \\
Otter Creek at Redhouse & $11 / 14 / 88$ & 93.6 \\
Hickman Creek near Mills & $11 / 15 / 88$ & 14.6 \\
Town Fork near Nicholasville & $11 / 16 / 88$ & 13.6 \\
Glenns Creek near Versailles & $11 / 16 / 88$ & 17.7 \\
North Elkhorn Creek at Great Crossing & $11 / 16 / 88$ & 3.8 \\
Town Branch near Lexington & $11 / 16 / 88$ & \\
Eagle Creek at Lusbys Mill & $11 / 16 / 88$ & \\
Heptachlor epoxide & & 28.1 \\
Town Branch near Lexington & $11 / 16 / 88$ & \\
Lindane & & 1.2 \\
South Fork Kentucky River at Boonevil1e & $11 / 15 / 88$ & 3.2 \\
Hickman Creek near Milis & $11 / 16 / 88$ & \\
\hline
\end{tabular}




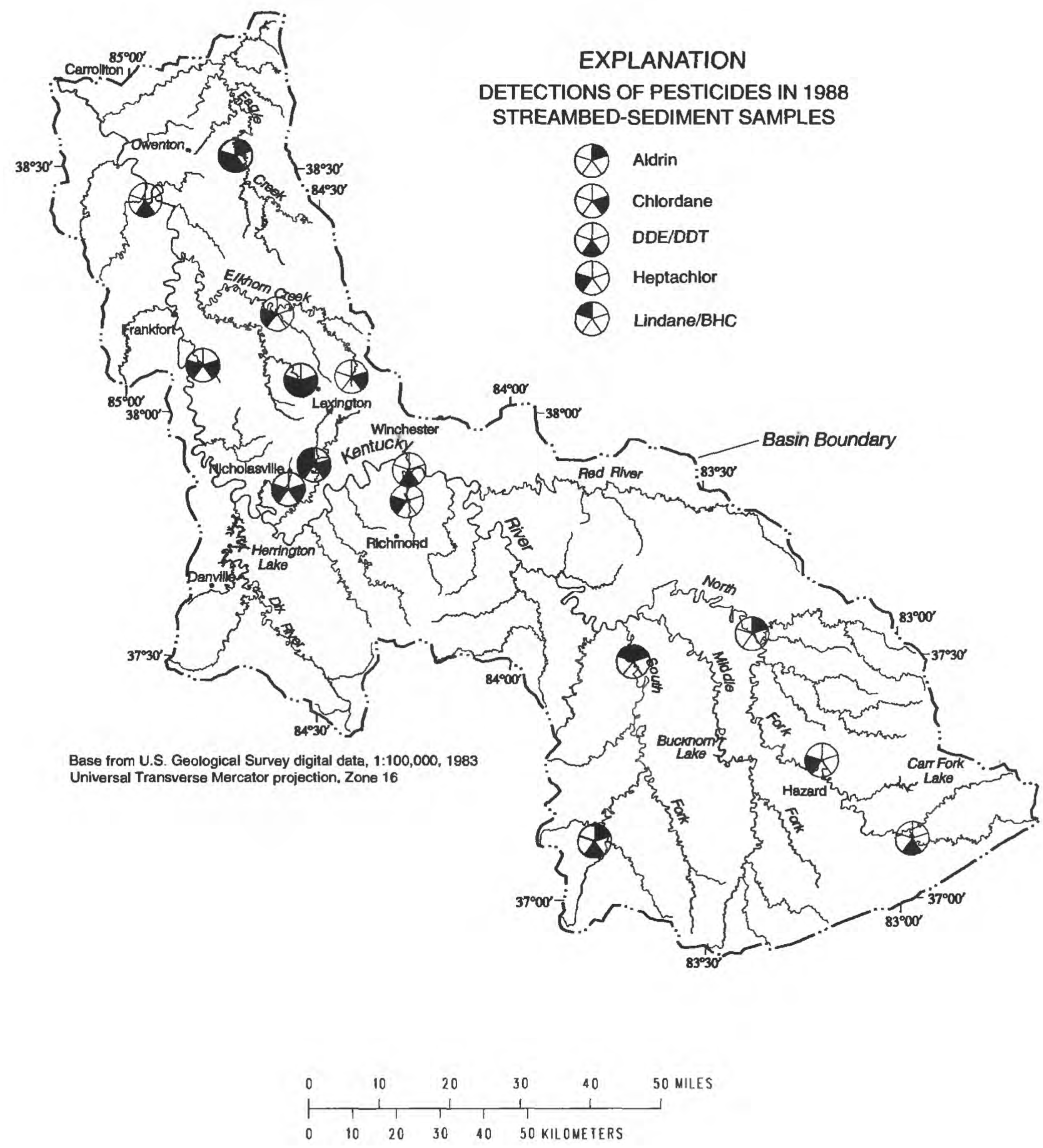

Figure 48. Detections of pesticides in streambed-sediment samples in the Kentucky River Basin, 1988. 
Currently (1994), standards or criteria have not been established for pesticides in bottom material by USEPA. These compounds can and do solubilize, however, and may be chronically present in the water column at low levels. The presence of pesticides in the water column solubilized from bed sediments at levels below the detection limits can be of concern because of the tendency of pesticides to bioaccumulate in the fat and tissues of aquatic animals. Studies in the San Joaquin River and its tributaries reported measurable levels of DDD, DDE, and DDT in fine-grained bed sediments associated with undesirable levels in fish from the San Joaquin River (Gilliom and Clifton, 1987). Investigators in the San Joaquin River study estimated concentrations of selected organochlorine pesticides in water from measured concentrations in bed sediments. In the case of dieldrin, a measured concentration of $8.9 \mu \mathrm{g} / \mathrm{kg}$ resulted in an estimated water concentration of $0.004 \mu \mathrm{g} / \mathrm{L}$, which exceeds the aquatic-life criterion for this compound (U.S. Environmental Protection Agency, 1986). A dieldrin concentration of $16.9 \mu \mathrm{g} / \mathrm{kg}$ was found in streambed sediments in Glenns Creek at Versailles, indicating possible concentrations in water that exceed aquatic-life criteria in the Kentucky River Basin. Concentrations of chlordane in surface water that exceed aquatic-life criteria might also be expected on the basis of concentrations in streambed sediments near Lexington.

\section{Occurrence of Pesticides in Fish and Macroinvertebrate Tissue}

Studies on the Mississippi River and some of its tributaries have indicated that numerous chlorinated pesticides and hydrocarbons can be found in fish tissue even though pesticide concentrations in the water are below detection limits (Leiker and others, 1991). Although the study design of the Kentucky River NAWQA project did not include tissue analyses, other studies in the basin indicate that certain pesticides are present and may affect the biota. Data collected by the KDOW illustrate the utility of multiple lines of evidence to determine the presence of pesticides. Sediment samples collected from eight sites in the Kentucky River below Bailey Run contained no detectable concentrations of pesticides, whereas fish tissue collected from the same sites contained detectable concentrations of chlordane, DDD, DDE, DDT, and dieldrin (Kentucky Natural Resources and Environmental Protection Cabinet, 1988b). Detectible concentrations of dieldrin, DDT, and chlordane were found in fish-tissue samples from the Red River near Hazel Green in 1986, whereas analyses of biological communities in this reach of the Red River generally indicated acceptable water quality (Bradfield and Porter, 1990).

Other examples of pesticides in tissues are available in the Kentucky River Basin. The KDOW reported chlordane residues of $320 \mu \mathrm{g} / \mathrm{kg}$ and $440 \mu \mathrm{g} / \mathrm{kg}$ in fish-tissue samples collected from the Kentucky River below Frankfort in 1984 (Kentucky Natural Resources and Environmental Protection Cabinet, 1986). These concentrations are slightly above U.S. Food and Drug Administration action levels of $300 \mu \mathrm{g} / \mathrm{kg}$. Tissues of three species of fishes at two sites in South Elkhorn Creek contained detectable concentrations of chlordane, dieldrin, DDT, DDE, and DDD (Kentucky Natural Resources and Environmental Protection Cabinet, 1983). Fish tissue from Eagle Creek contained detectible concentrations of chlordane, PCB's, DDT, and methoxychlor (M.R. Mills, Kentucky Division of Water, written commun., 1988). 
A small-scale sampling of the Asiatic clam Corbicula fluminea was done in this NAWQA study in E1khorn Creek near Frankfort in Apri1 1992 to gain an understanding of the accumulation of pesticides in macroinvertebrate tissue. Tissue samples were pooled, and seven subsamples were analyzed for organochlorine insecticides. DDE was present at a concentration of $5.15 \mu \mathrm{g} / \mathrm{kg}$, and nonachlor at $9.89 \mu \mathrm{g} / \mathrm{kg}$. Lindane (gamma $\mathrm{HCH}$ ) was present at $4.67 \mu \mathrm{g} / \mathrm{kg}$, and chlordane was detected at $9.66 \mu \mathrm{g} / \mathrm{kg}$. Heptachlor epoxide, endrin, and DDD were detected at or below reporting levels. These compounds were all found in bed sediment at sites in the Kentucky River Basin in the course of the NAWQA project; however, none were found at the Elkhorn Creek at Frankfort site. These data illustrate the utility of tissue analyses as a compliment to bed-sediment analyses to ascertain the occurrence and distribution of hydrophobic pesticides.

\section{Relation of Pesticides to Land Uses and Other Human Activities}

Pesticides in surface water in the Kentucky River Basin can originate from many sources. These include, but are not limited to, application of herbicides and insecticides to agricultural cropland, use of herbicides on golf courses and other recreational turf, residential herbicide and pesticide use, and application of insecticides for urban mosquito control.

\section{Agricultural 1and use}

The use of agrichemicals can be inferred from an examination of the distribution of cropland in conjunction with an analysis of information on agricultural pesticide sales. The distribution of agricultural croplands in the Kentucky River Basin is shown in figure 22. These distributional patterns are noteworthy because they indicate probable patterns of pesticide application, based on common practice. Wide-scale use of agricultural chemicals is confined to production of corn, soybeans, tobacco, alfalfa, and wheat. Areas 1ying within the Inner and Outer Bluegrass Region are important agricultural areas--particularly for livestock and tobacco (figs. 23 and 24)-but most farms are general-purpose operations that raise a mix of forage crops, tobacco, and grains. For example, the ratio of row crops (corn, soybeans, wheat, alfalfa, and tobacco) to total agricultural acreage is relatively low in Henry County (15 percent), Fayette County (13 percent), Scott County ( 9 percent), Clark County ( 8 percent), and Madison County ( 6 percent) (University of Kentucky, 1993a). Therefore, the extensive acreages of single-row crops found elsewhere, which involve the use of large amounts of pesticides, would not be expected in the Kentucky River Basin.

Corn and other row crops are common in the upper part of the Kentucky River Basin, although agriculture is not the dominant land use. Row crops are commonly found along streams. Detections of pesticides such as atrazine and 2,4-D in streams in Breathitt, Lee, and Owsley Counties indicate that although the percentage of land use devoted to agriculture may be small, the possibility for contamination of streams does exist, particularly where agricultural land is adjacent to streams. 
Agricultural sales data summarize the use of numerous pesticides in the counties within the basin. By assuming that the point of application is near the point of sale, one can infer patterns of agricultural application of these chemicals. The counties of Clark, Fayette, Madison, and Scott all had relatively high agricultural sales of several commonly used herbicides (figs. 49-51) and insecticides (figs. 52-53) in 1989. Many of the detections of pesticides in the Kentucky River Basin occurred in counties of the Bluegrass Region where agricultural land use is dominant. However, the limited frequency and distribution of our sample sites prohibits the definition of cause and effect relations between application patterns and occurrence in water and streambed sediments.

\section{Urban land use}

The use of certain pesticides can be linked to patterns of urban land use. The counties with the greatest population $(>20,000)$ in the Kentucky River Basin include Clay, Fayette, Franklin, Jessamine, Letcher, Madison, Perry, and Scott (fig. 5). All these counties have at least one urban population center. As noted previously, population distribution has changed over the last 10 years, with density increasing in urban areas and decreasing in rural areas. When urbanization occurs, increased residential pesticide application can be expected not only from homeowners but also from certified pesticide applicators. A concomitant increase in pesticide use on golf courses, cemeteries, school grounds, public parks, and roadside turf is frequently observed. Turf-maintenance expenses in Kentucky in 1989 included expenditures on pesticides of $\$ 11,076,000$ (Kentucky Agricultural Statistics Service, 1991), indicating the magnitude of pesticide application.

Statistical data on residential sales of pesticides by retail outlets are not available. Estimates of pesticide application by certified applicators employed by commercial lawn-care firms are available. The principal pesticides applied by lawn-care companies and found in water samples collected in the Kentucky River Basin in 1990 are summarized by county in table 17 . In the counties of Fayette, Franklin, Jessamine, Scott, and Woodford, which are all relatively urbanized, sales of pesticides used by commercial lawn-care companies were considerable, and detection sites for herbicides and organophosphate insecticides were numerous. However, limitations in the number and distribution of sample sites preclude statistical analyses of these data.

The occurrence of DDT in sediment samples in the Kentucky River Basin may be linked in part to residential pesticide use. Although not approved for sale and use as a principal active ingredient, DDT is a component, or known impurity, of approved commercial products that contain other principal active ingredients. For example, DDT may constitute as much as 15 percent of Kelthane (dicofol) (Miller, 1988). In 1982, an estimated 1,166,099 $1 \mathrm{~b}$ active ingredient of dicofol were imported and used in the United States. According to the Kentucky Division of Pesticides (Ernest Collins, written commun., 1993), there were no agricultural sales of Kelthane in Kentucky during 1990-91; however, eight commercial applicators sold or applied Kelthane in lawn-care operations in 1991, and one of these operations was in Fayette County in the Kentucky River Basin. 


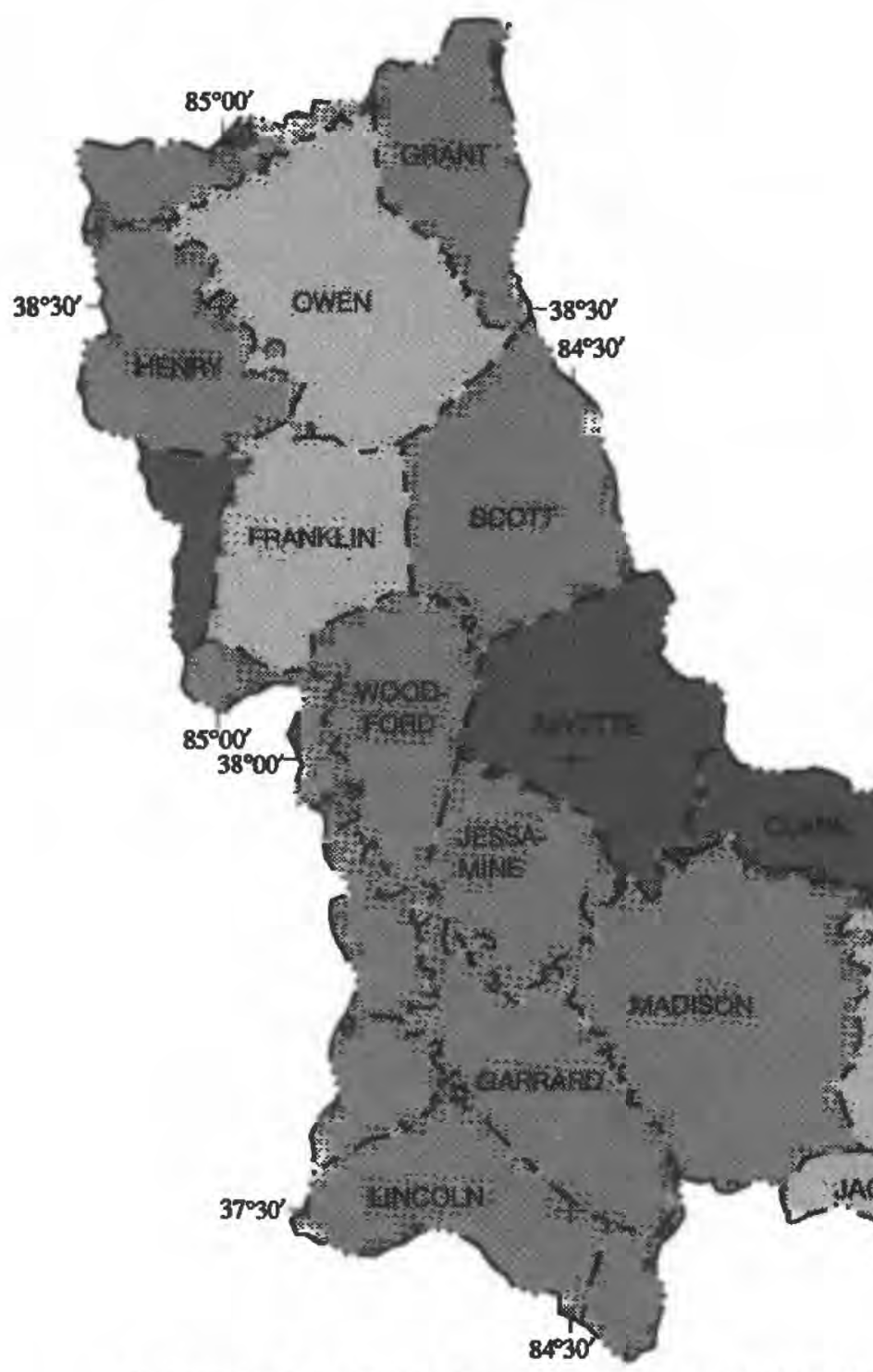

Base from U.S. Geological Survey digital data, 1:100,000, 1983 Universal Transverse Mercator projection, Zone 16

\section{EXPLANATION \\ ATRAZINE SALES, IN POUNDS \\ [<, LESS THAN; >, GREATER THAN]}

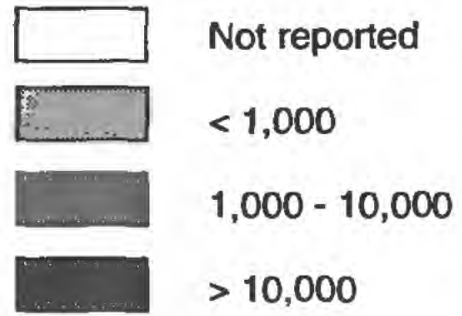

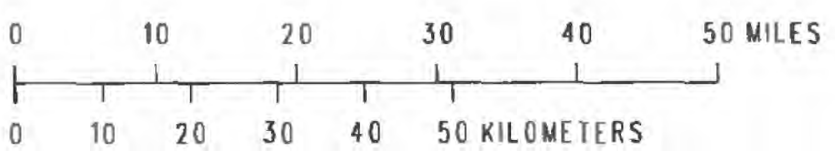

Figure 49. Agricultural sales of atrazine, by county, in the Kentucky River Basin, 1989. 


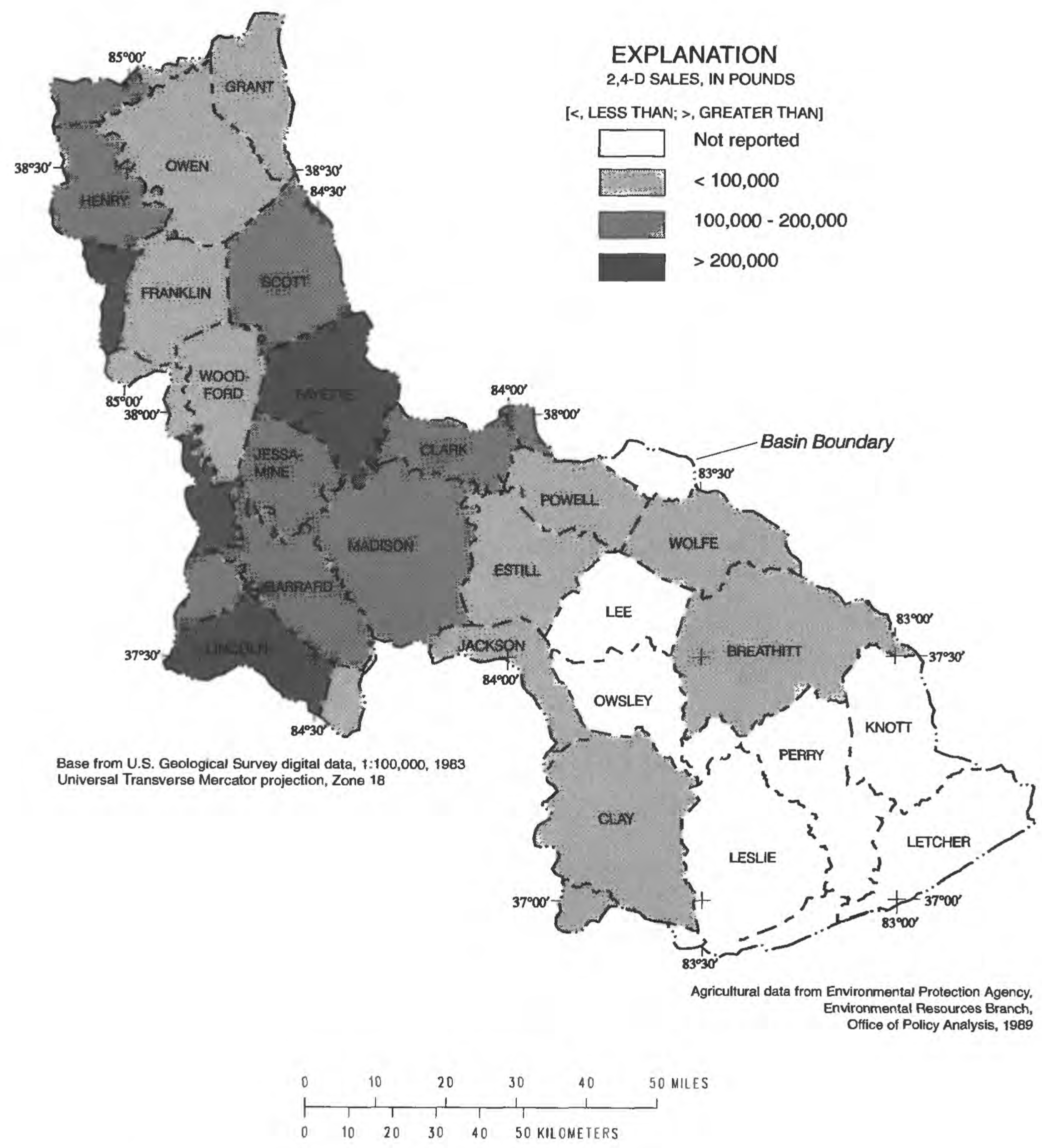

Figure 50. Agricultural sales of 2,4-D, by county, in the Kentucky River Basin, 1989. 


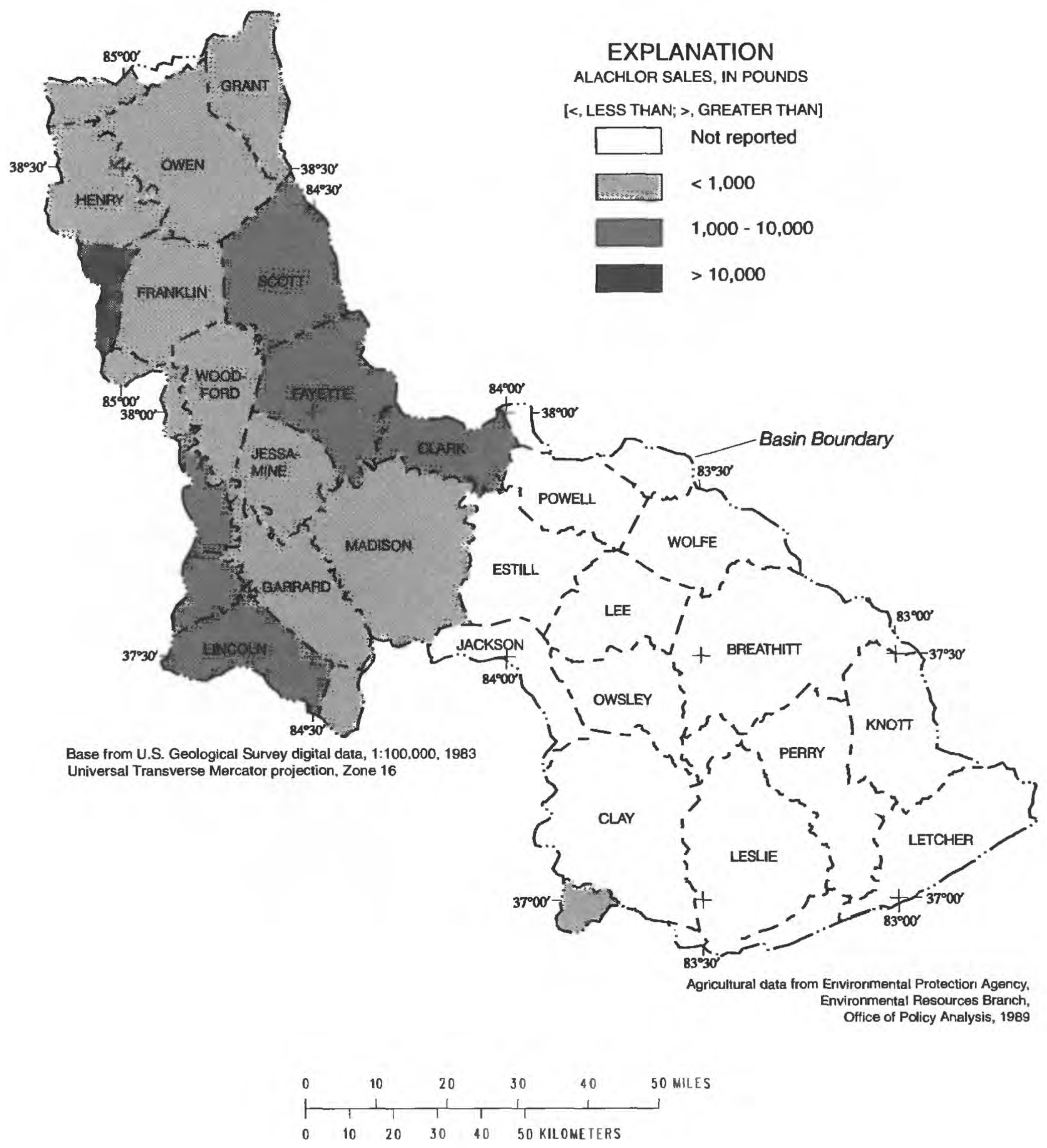

Figure 51. Agricultural sales of alachlor, by county, in the Kentucky River Basin, 1989. 


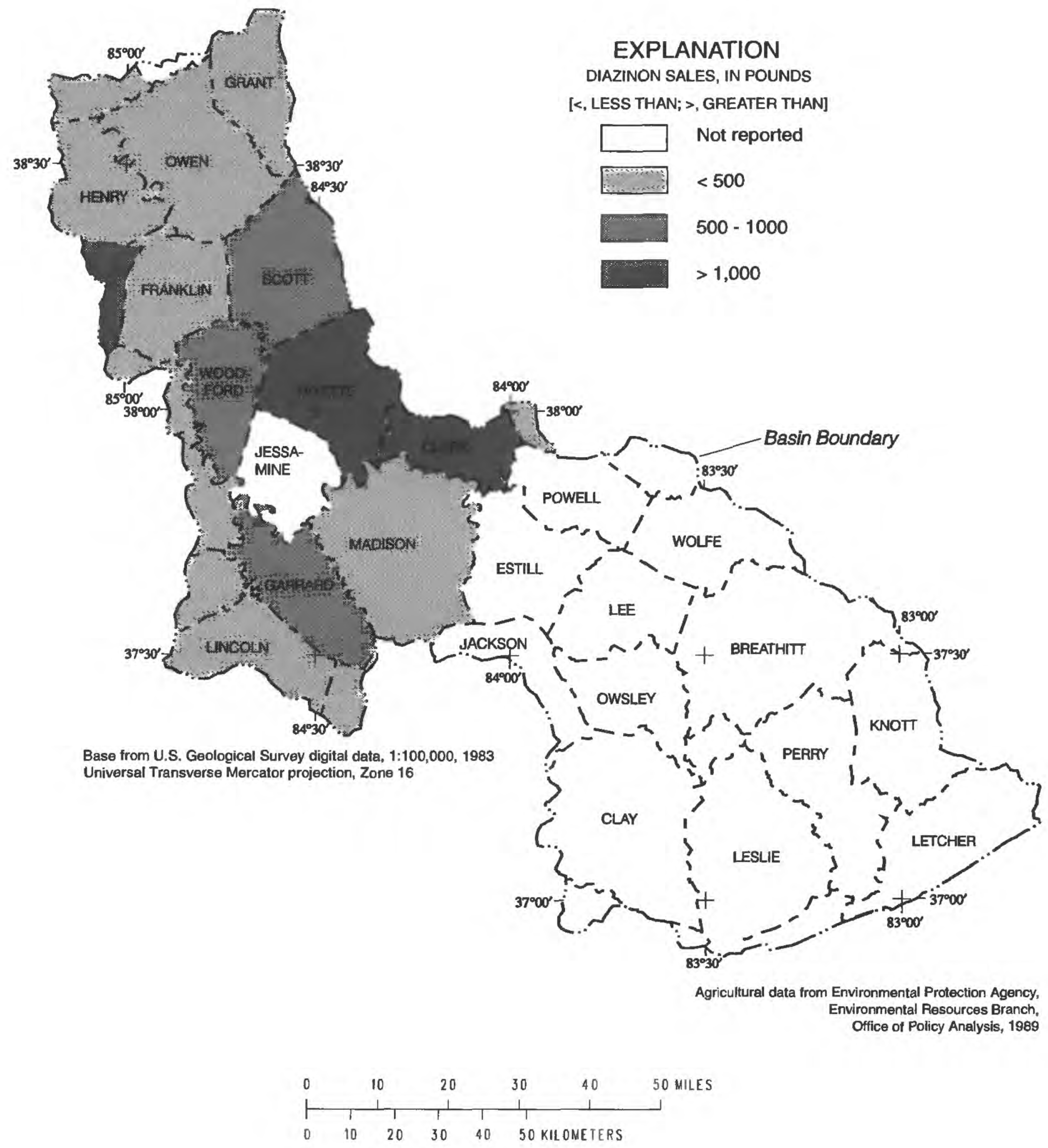

Figure 52. Agricultural sales of diazinon, by county, in the Kentucky River Basin, 1989. 


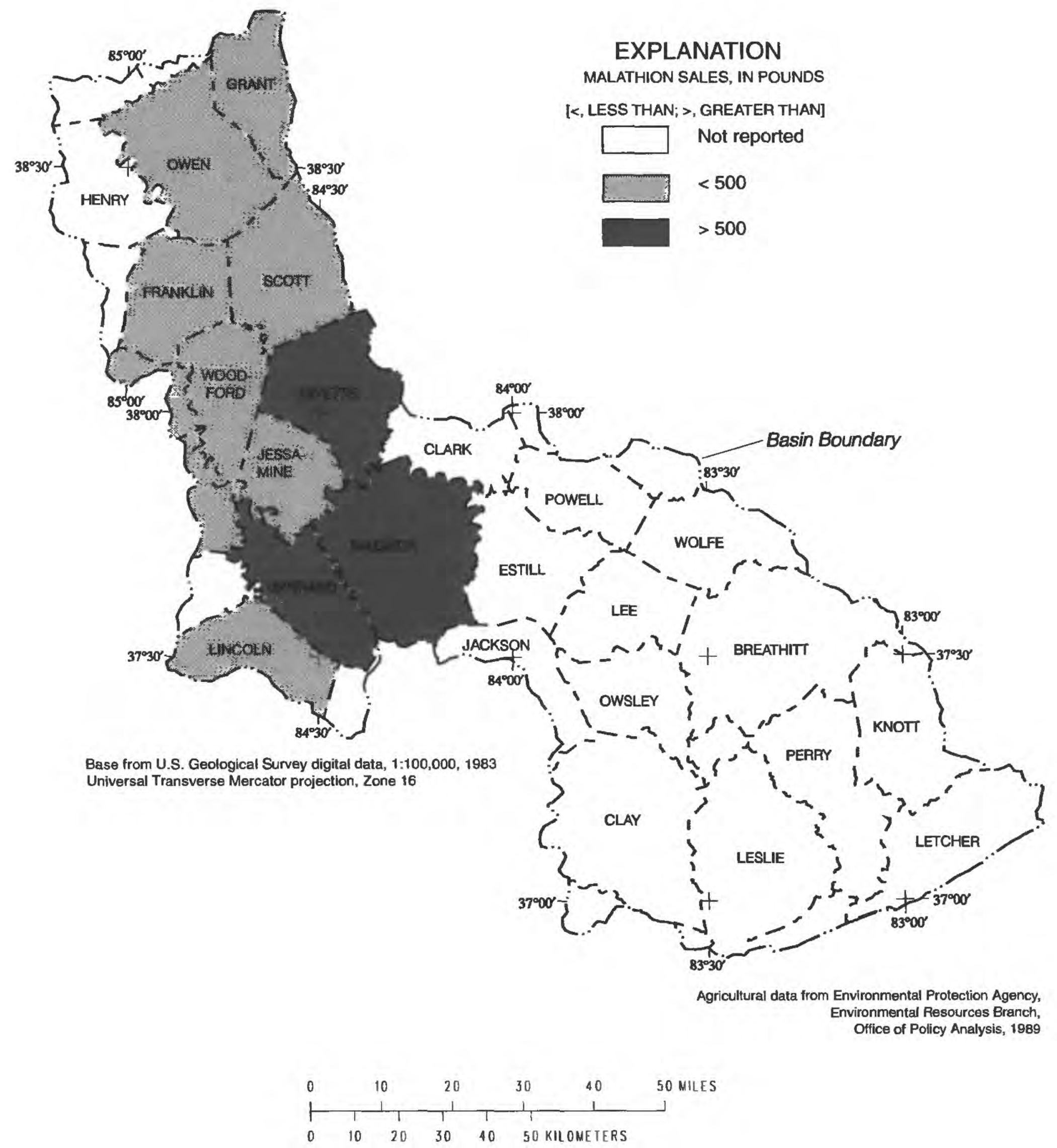

Figure 53. Agricultural sales of malathion, by county, in the Kentucky River Basin, 1989. 


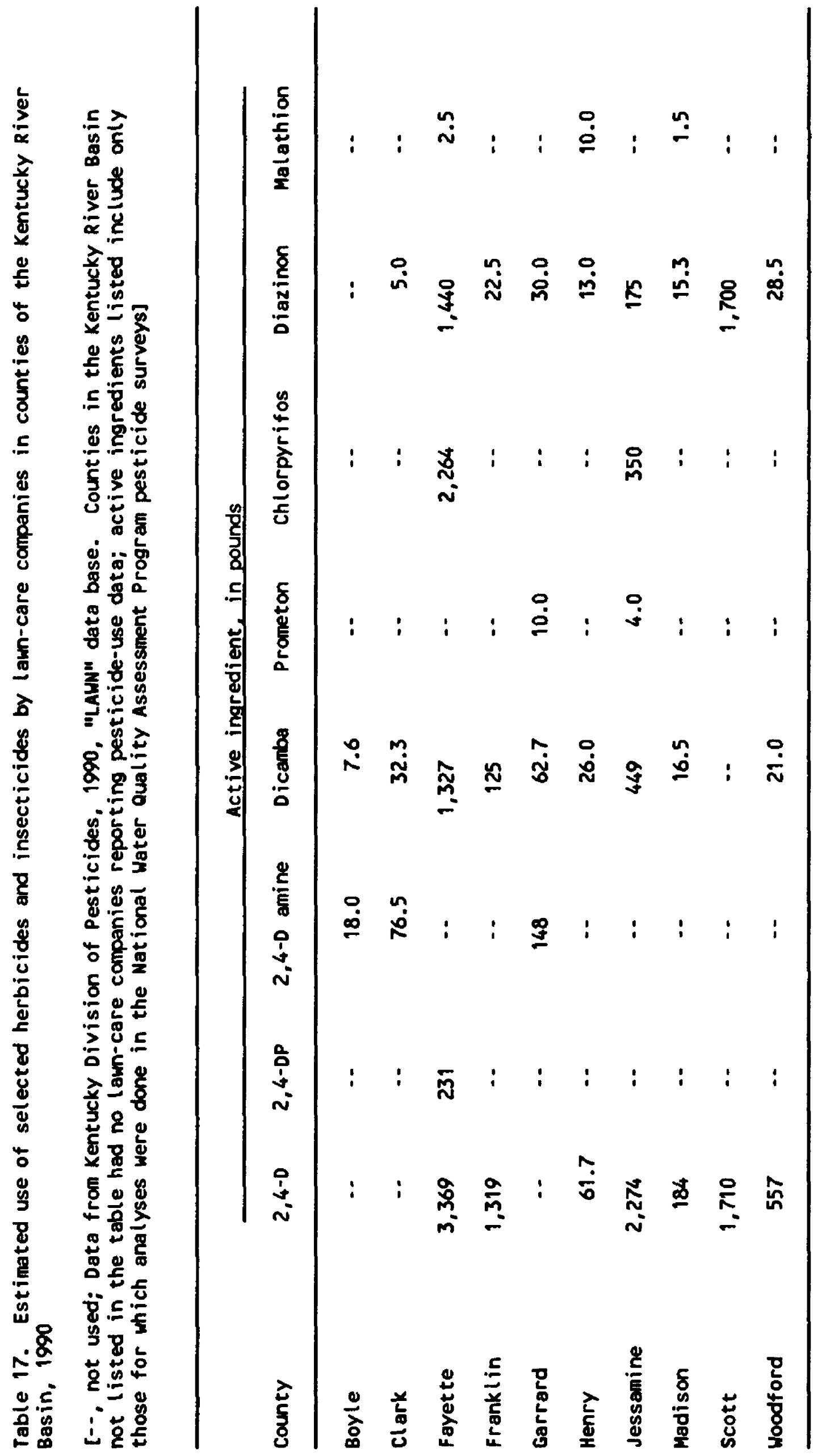




\section{SUMMARY AND CONCLUSIONS}

The U.S. Geological Survey collected water and sediment samples from streams in the Kentucky River Basin, Kentucky, during April 1987-March 1990 as part of the National Water Quality Assessment Program. Seven fixed stations were sampled monthly during the study period. A total of 75 synoptic sites were sampled during low flow (August 1987 and August 1988), when the effects of point-source discharges were predominant. Samples from throughout the $7,000 \mathrm{mi}^{2}$ basin were analyzed for concentrations of nutrients, suspended sediment, and pesticides. Chlorophyll a concentrations and algal cell densities also were measured at several synoptic sites. Mean annual loads and yields of water-quality constituents were estimated at sites where at least 2 years of streamflow data had been collected. Efforts were made to identify factors affecting instream concentrations and loads of constituents.

Generally, nutrient concentrations at the fixed stations did not vary significantly from year to year. Concentrations of total ammonia and organic nitrogen ranged from less than $0.2 \mathrm{mg} / \mathrm{L}$ to $3.4 \mathrm{mg} / \mathrm{L}$ at these sites, whereas concentrations of dissolved nitrite plus nitrate nitrogen ranged from less than $0.01 \mathrm{mg} / \mathrm{L}$ to $8.5 \mathrm{mg} / \mathrm{L}$. Total phosphorus concentrations ranged from less than $0.01 \mathrm{mg} / \mathrm{L}$ to $5.7 \mathrm{mg} / \mathrm{L}$. At the E1khorn Creek at Frankfort station, however, total phosphorus and total nitrogen concentrations appeared to be higher in 1987 than in the other years.

Estimates of mean annual total phosphorus loads at the fixed stations were relatively low in the upper end of the basin, ranging from 32.6 tons in the Middle Fork of the Kentucky River at Tallega to 94.2 tons in the North Fork of the Kentucky River at Jackson. Phosphorus loads were an order of magnitude higher ( 1,920 tons) at the most downstream site (Kentucky River at Lock 2). Estimates of the mean annual load of dissolved nitrite plus nitrate nitrogen ranged from 192 tons in the Middle Fork of the Kentucky River at Tallega to 9,170 tons in the Kentucky River at Lock 2. Mean annual yield estimates for total phosphorus and for nitrite plus nitrate nitrogen were highest in Elkhorn Creek at Frankfort ( 0.95 tons $/ \mathrm{mL}^{2}$ and 5.32 tons $/ \mathrm{ml}^{2}$, respectively), because of upstream discharges of wastewater-treatment-plant (WWTP) effluent.

A1though no statistically significant correlations were found between nutrient concentrations and discharge, high concentrations of phosphorus were generally found at high discharges in rural (nonurban) areas where nonpointsource runoff is dominant. High concentrations of total nitrogen were found at both the upper and lower extremes of discharge in the lower part of the basin near the mouth of the Kentucky River, reflecting the combined effects of point and nonpoint sources of constituents. Significant correlations were found between concentrations of total phosphorus and suspended sediment. At many sampling sites in urban areas, most of the stream nitrogen load was attributable to WWTP discharges, even when only a small proportion of the total stream discharge was composed of WWTP discharges. Instream nitrogen concentrations at synoptic sites downstream from WWTP's were among the highest measured in the Kentucky River Basin. For example, concentrations of nitrite plus nitrate nitrogen exceeded $10.0 \mathrm{mg} / \mathrm{L}$ in Hickman Creek near Mills and in Clarks Creek near Stewartsville in August 1987 and in Town Branch near Lexington in August 1988. 
Significant correlations were not found between land-use type and concentrations of nitrogen forms at the fixed sites. Concentrations of phosphorus, however, were positively correlated with urban and agricultural land use and negatively correlated with forest and mining land use. The high phosphorus content of soils in the Inner and Outer Bluegrass Regions presumably contributes to concentrations of phosphorus in streams of these physiographic regions. No correlations between nutrients and land-use type were indicated at the synoptic sites, although high concentrations of phosphorus were also found in areas where urban or agricultural land use predominated.

Phytoplankton chlorophyll a concentrations in the main stem of the Kentucky River during low flows correlated positively with concentrations of total phosphorus and total ammonia plus organic nitrogen. The positive correlation of chlorophyl1 a with total ammonia plus organic nitrogen indicates that a considerable proportion of total nitrogen was transported as algal biomass during periods of low discharge. The highest algal cell densities and the highest concentrations of chlorophyll a were found in the lower Kentucky River, downstream from river mile 180. In tributary streams, phytoplankton chlorophyll a concentrations also correlated positively with concentrations of total phosphorus and total ammonia plus organic nitrogen. In August 1987 and August 1988, several streams affected by urban sources of nutrient enrichment contained relatively low concentrations of phytoplankton chlorophyll a, indicating that periphyton probably dominated the algal community in those streams. Streams affected by agricultural sources of nutrients contained higher densities of phytoplankton than streams that drained forested subbasins. Median concentrations of chlorophyll a and algal cell density were significantly lower in streams that drained surface-mined areas than in streams that drained agricultural and urban lands.

Median suspended-sediment concentrations ranged from 18 to $31 \mathrm{mg} / \mathrm{L}$ at the main-stem sites. The maximum suspended-sediment concentration in the study area was found in the North Fork of the Kentucky River at Jackson $(1,780 \mathrm{mg} / \mathrm{L})$, an area where mining activities are a predominant land use. The median concentration of suspended sediment in Elkhorn Creek at Frankfort $(10 \mathrm{mg} / \mathrm{L})$ was the lowest among the fixed stations. The trend in suspendedsediment concentrations during the study was a downstream decrease in the Kentucky River main stem from the headwaters to the mouth. Suspended-sediment concentrations were correlated with discharge at the fixed stations; concentrations were always lower in summer, which is typically a low-flow period, than in any other season of the year. No significant correlations were found between suspended-sediment concentrations and any nutrient forms in the Kentucky River Basin, with the exception of phosphorus. No correlations were found between land use and total suspended-sediment concentrations, although the level of resolution of land-use data may not have been adequate to reflect differences at the subbasin scale. A significant 15-year-long downward flow-adjusted trend in suspendzd-sediment concentrations was indicated for the Kentucky River at Lock 2. The downward trend may have resulted from the implementation of best management practices to reduce soil erosion from surface-mining and agricultural activities in the Kentucky River Basin. 
Atrazine was found in water samples at sites throughout the Kentucky River Basin. Concentrations of triazine herbicides rarely exceeded $0.5 \mu \mathrm{g} / \mathrm{L}$, but water samples collected in June 1989 from North Elkhorn Creek at Georgetown contained unusually high concentrations of atrazine $(16.0 \mu \mathrm{g} / \mathrm{L})$ and simazine $(4.5 \mu \mathrm{g} / \mathrm{L})$. Other herbicides frequently found were 2,4-D, alach1or, metolachlor, and dicamba. Diazinon, malathion, and parathion were the most frequently detected organophosphate insecticides in water samples, particularly in the Elkhorn Creek Basin. At two sites, concentrations of pesticides in water samples exceeded the USEPA Maximum Contaminant Levels (MCL's) for drinking water (atrazine in North Elkhorn Creek at Georgetown) and acute and chronic aquatic-life criteria (malathion and parathion in South Elkhorn Creek at Midway).

Analyses of streambed-sediment samples resulted in frequent detections of several organochlorine insecticides, including aldrin, chlordane, DDT, DDE, dieldrin, endrin, endosulfan, heptachlor, heptachlor epoxide, and lindane. Chlordane was found at concentrations ranging from 59.4 to $268.7 \mu \mathrm{g} / \mathrm{kg}$ in Hickman Creek, Town Fork, Town Branch, Glenns Creek, and North Elkhorn Creek. Many of the pesticides detected in the Kentucky River Basin were in counties of the Bluegrass Region, where agricultural land use is dominant. Data indicated that residential pesticide application in urban areas in the Bluegrass Region also might affect the distribution of pesticides such as 2,4-D and diazinon in streams.

In conclusion, the temporal and spatial variability of nutrients, suspended sediments, and pesticides in the Kentucky River Basin were affected by numerous factors, including land-use type, agricultural and urban runoff, WWTP discharges, and the distribution of algal populations. Nutrients in WWTP effluent had substantial effects on water quality during low flows in many tributary streams. The temporal variability of nutrients and dissolved oxygen was strongly affected by the presence of algal populations, particularly in the Kentucky River main stem. A large amount of suspended sediment originates in the Eastern Coal Field Region, but contributions of suspended sediment from the Red River and other tributary streams of the Knobs Region also are substantial. Water and streambed-sediment samples collected at sites throughout the basin contained numerous herbicides and insecticides, reflecting agricultural as well as residential pesticide-use patterns. 


\section{REFERENCES CITED}

Adams, W.J., Kimerle, R.A., and Barnett, J.W., 1992, Sediment quality and aquatic life assessment: Environmental Science \& Technology, v. 26, no. 10 , p. $1865-1875$.

American Society of Civil Engineers, Task Committee on Sediment Transport and Aquatic Habitats, Sedimentation Committee, 1992, Sediment and aquatic habitat in river systems: Journal of Hydraulic Engineering, v. 118, no. 5, p. $669-687$.

Beaulac, M.N., and Reckhow, K.H., 1982, An examination of land use-nutrient export relationships: Water Resources Bulletin, v. 18, p. 1013-1024.

Biggar, J.W., and Seiber, J.N., 1987, Fate of pesticides in the environment: Oakland, Calif., University of California, Agricultural Experiment Station Publication 3320,157 p.

Bradfield, A.D., and Porter, S.D., 1990, Summary of biological investigations relating to surface-water quality in the Kentucky River basin, Kentucky:

U.S. Geological Survey Water-Resources Investigations Report 90-4051, $63 \mathrm{p}$.

Britton, L.J., and Greeson, P.E., eds., 1989, Methods for collection and analysis of aquatic biological and microbiological samples:

U.S. Geological Survey Techniques of Water-Resources Investigations, book 5, chap. A4, 363 p.

Butler, D.L., 1987, Pesticide data for selected Wyoming streams, 1976-78: U.S. Geological Survey Water-Resources Investigations Report 83-4127, $41 \mathrm{p}$.

Canfield, D.E., Linda, S.B., and Hodgson, L.M., 1985, Chlorophyl1-biomassnutrient relationships for natural assemblages of Florida phytoplankton: Water Resources Bulletin, v. 21, no. 3, p. 381-391.

Clesceri, L.S., Greenberg, A.E., and Trussel, R.R., eds., 1989, Standard methods for the examination of water and wastewater (17th ed.): American Public Health Association, American Water Works Association [variously paged].

Currens, J.C., Carey, D.I., and Dinger, J.S., 1991, The reconnaissance of the groundwater resources of the Kentucky River basin: Lexington, Ky., University of Kentucky, Kentucky Geological Survey, 29 p.

Decker, Ronnie, ed., 1991, Kentucky economic statistics: Frankfort, Ky., Department of Existing Business and Industry, Division of Research and Planning, $129 \mathrm{p}$.

deNoyelles, F., Kettle, W.D., and Sinn, D.E., 1982, The responses of plankton communities in experimental ponds to atrazine, the most heavily used pesticide in the United States: Ecology, v. 63, no. 5, p. 1285-1293. 
Dewey, S.L., 1986, Effects of the herbicide atrazine on aquatic insect community structure and emergence: Ecology, v. 67, p. 148-162.

Edwards, M.D., Putnam, A.L., and Hutchinson, N.E., 1986, Conceptual design for the National Water Information System: U.S. Geological Survey Open-File Report 86-604, 37 p.

Edwards, T.K., and Glysson, G.D., 1988, Fleld methods for measurement of fluvial sediment: U.S. Geological Survey Open-File Report 86-531, 118 p.

Elam, A.B., Jr., Haan, C.T., Barfield, B.J., and Bridges, T.C., 1972, Precipitation probabilities for Kentucky: Lexington, Ky., University of Kentucky, College of Agriculture, Progress Report 202, 55 p.

Faust, R.J., Banfield, G.R., and Willinger, G.Q., 1980, A compilation of ground water quality data for Kentucky: U.S. Geological Survey Open-File Report 80-685, $963 \mathrm{p}$.

Federa1 Interagency Sedimentation Project, 1963, Determination of fluvia1 sediment discharge: Minneapolis, Minn., St. Anthony Falls Hydraulics Laboratory, Report 14, 29 p.

Fishman, M.J., and Friedman, L.C., eds., 1989, Methods for determination of inorganic substances in water and fluvial sediments: U.S. Geological Survey Techniques of Water-Resources Investigations, book 5, chap. Al, $545 \mathrm{p}$.

F1int, R.F., 1983, Fluvial sedimentation in Kentucky: U.S. Geological Survey Water-Resources Investigations Report 83-4152, 75 p.

Friedman, L.C., and Erdman, D.E., 1983, Quality assurance practices for the chemical and biological analyses of water and fluvial sediments:

U.S. Geological Survey Techniques of Water-Resources Investigations, book 5, chap. A6, $181 \mathrm{p}$.

Garcia, Rene, Sholar, C.J., and Toms, S.G., 1989, Water resources data, Kentucky, water year 1988: U.S. Geological Survey Water-Data Report $\mathrm{KY}-88-1,569 \mathrm{p}$.

1990, Water resources data, Kentucky, water year 1989: U.S. Geological Survey Water-Data Report KY-89-1, $461 \mathrm{p}$.

Gianessi, L.P., 1986, Water pollutant discharges and pesticide usage estimates for NAWQA surface-water study regions: Washington, D.C., Resources for the Future, $19 \mathrm{p}$.

Gilliom, R.J., and Clifton, D.G., 1987, Organochlorine pesticide residues in bed sediments of the San Joaquin River and its tributary streams:

U.S. Geological Survey Open-File Report 87-531, 15 p. 
Goolsby, D.A., Coupe, R.C., and Markovchick, D.J., 1991, Distribution of selected herbicides and nitrate in the Mississippi River and its major tributaries, April through June 1991: U.S. Geological Survey WaterResources Investigations Report 91-4163, 35 p.

Griffin, M.S., Martin, G.R., and White, K.D., 1994, Surface-water-quality assessment of the Kentucky River Basin, Kentucky--Fixed-station network and selected water-quality data, April 1987 through August 1991:

U.S. Geological Survey Water-Resources Investigations Report 94-4029.

Guy, H.P., and Norman, V.W., 1970, Field methods for measurements of fluvial sediment: U.S. Geological Survey Techniques of Water-Resources Investigations, book 3 , chap. C2, $59 \mathrm{p}$.

Helsel, D.R., 1991, Less than obvious--statistical treatment of data below the detection limit: Environmental Science \& Technology, v. 24, no. 12, p. $1766-1774$.

Hem, J.D., 1985, study and interpretation of the chemical characteristics of natural water ( $3 d$ ed.): U.S. Geological Survey Water-Supply Paper 2254 , $264 \mathrm{p}$.

Hil1, C.L., 1991, Effects of land-management practices on sediment yields in northeastern Guilford County, North Carolina: U.S. Geological Survey Water-Resources Investigations Report 90-4127, $40 \mathrm{p}$.

Hirsch, R.M., Alley, W.M., and Wilber, W.G., 1988, Concepts for a national water-quality assessment program: U.S. Geological Survey Circular 1021, $42 \mathrm{p}$.

Horowitz, A.J., 1991, A primer on sediment-trace-element chemistry: Chelsea, Mich., Lewis Publishers, $136 \mathrm{p}$.

Howard, P.H., ed., 1991, Handbook of environmental fate and exposure data for organic chemicals: Boca Raton, Fla., Lewis Publishers, 684 p.

Hutchinson, N.E., 1975, WATSTORE user's guide, volume 1: U.S. Geological Survey Open-File Report 75-426 [variously paged].

Hynes, H.B.N., 1970, The ecology of running waters: Liverpool, England, Liverpool University Press, 555 p.

Jones, B.E., 1987, Quality control manual of the U.S. Geological Survey's National Water-Quality Laboratory: U.S. Geological Survey Open-File Report 87-457, $17 \mathrm{p}$.

Kentucky Agricultural Statistics Service, 1991, Kentucky Agricultural Statistics 1990-1991: Louisville, Ky., 159 p.

Kentucky Environmental Quality Commission, 1992, State of Kentucky's environment--a report of progress and problems: Frankfort, Ky., Kentucky Environmental Quality Commission, $332 \mathrm{p}$. 
Kentucky Natural Resources and Environmental Protection Cabinet, 1983, South Elkhorn Creek drainage biological and water quality investigation for stream use designation: Frankfort, Ky., Kentucky Natural Resources and Environmental Protection Cabinet, Division of Water, Technical Report 2, $133 \mathrm{p}$.

1986, 1986 Kentucky report to Congress on water quality: Frankfort, Ky., Kentucky Natural Resources and Environmental Protection Cabinet, Division of Water, $192 \mathrm{p}$.

1988a, Kentucky standard operating procedure and quality assurance manual for the ambient surface water monitoring program: Frankfort, Ky., Kentucky Natural Resources and Environmental Protection Cabinet, Division of Water, $57 \mathrm{p}$.

1988b, Bailey Run/Cedar Brook drainage biological and water quality investigation: Frankfort, Ky., Kentucky Natural Resources and Environmental Protection Cabinet, Division of Water, Technical Report 27 , $91 \mathrm{p}$.

1992, Kentucky report to Congress on water quality: Frankfort, Ky., Kentucky Natural Resources and Environmental Protection Cabinet, Division of Water, $187 \mathrm{p}$.

Kiesler, J.L., Woosley, L.H., Jr., and Davis, R.W., 1986, National Water Summary 1986--Kentucky ground-water quality: U.S. Geological Survey Water-Supply Paper 2325, p. 265-272.

Leiker, T.J., Rostad, C.E., Barnes, C.R., and Pereira, W.E., 1991, A reconnaissance of halogenated organic compounds in catfish from the lower Mississippi River and its major tributaries: Chemosphere, v. 23, no. 7 , p. $817-829$.

Mallevialle, J., and Suffet, I.H., 1987, Identification and treatment of tastes and odors in drinking water: Denver, Colo., American Water Works Association, 292 p.

Martin, G.R., Smoot, J.L., and White, K.D., 1993, A comparison of surface-grab and cross sectionally integrated stream-water-quality sampling methods: Water Environment Research, v. 64, no. 7, p. 866-876.

Mattraw, H.C., Jr., Wilber, W.G., and Alley, W.M., 1989, Quality-assurance plan for the pilot National Water-Quality Assessment program:

U.S. Geological Survey Open-File Report 88-726, 21 p.

McElroy, F.T.R., and Bell, J.M., 1974, Stormwater runoff quality for urban and semi-urban/rural watersheds: West Lafayette, Ind., Purdue University Water Resources Research Center, Technical Report 43, 156 p.

Melcher, N.B., and Ruh1, K.J., 1984, Streamflow and basin characteristics at selected sites in Kentucky: U.S. Geological Survey Open-File Report 84-704, 80 p. 
Miller, G.T., 1988, Living in the environment: Belmont, Calif., Wadsworth Publishing Company, 603 p.

Miller, Wihry, and Lee, Incorporated, 1975, The river basin water quality management plan for Kentucky--Kentucky River: Frankfort, Ky., Kentucky Natural Resources and Environmental Protection Cabinet, 123 p.

National Atmospheric Deposition Program, 1991, NADP/NTN annual data summary, precipitation chemistry in the United States, 1990: Fort Collins, Colo., Colorado State University, Natural Resource Ecology Laboratory, 475 p.

Odum, H.T., 1956, Primary production in flowing waters: Limnology and Oceanography, v. 1, no. 2, p. 102-117.

Perry, C.A., 1991, Observed and simulated distribution of selected herbicides in silty loam, sandy loam, and clay soil profiles near Topeka, Kansas, 1986-88: U.S. Geological Survey Water-Resources Investigations Report 91-4017, 61 p.

Puckett, L.J., 1994, Nonpoint and point sources of nitrogen in major watersheds of the United States: U.S. Geological Survey Water-Resources Investigations Report 94-4001, 9 p.

Searcy, J.K., 1969, Flow-duration curves; manual of hydrology, part 2, lowflow techniques: U.S. Geological Survey Water-Supply Paper 1542-A, 33 p.

Singh, K.P., and Durgunoglu, Ali, 1992, Predicting sediment loads: Civil Engineering, v. 62, no. 11, p. 64-65.

Smith, J.A., Witkowski, P.J., and Fusillo, T.V., 1988, Manmade organic compounds in the surface waters of the United States--a review of current understanding: U.S. Geological Survey Circular 1007, 92 p.

Smith, V.H., 1979, The nutrient dependence of primary productivity in lakes: Limnology and Oceanography, v. 24, p. 1051-1064.

1983, Light and nutrient dependence of photosynthesis by algae: Journal of Phycology, v. 19, p. 306-313.

Smoot, J.L., Liebermann, T.D., Evaldi, R.D., and White, K.D., 1991, Surface water-quality assessment of the Kentucky River basin, Kentucky--analysis of available water-quality data through 1986: U.S. Geological survey Open-File Report 90-360, 209 p.

Stevenson, R.J., and White, K.D., 1995, A comparison of natural and human determinants of phytoplankton communities in the Kentucky River Basin, USA: Hydrobiologia, v. 297, no. 3, p. 201-216.

Thurman, E.M.,.Goolsby, D.A., Meyer, M.T., Mills, M.S., Pomes, M.L., and Kolpin, D.W., 1992, A reconnaissance study of herbicides and their metabolites in surface water of the midwestern United States using immunoassay and gas chromatography/mass spectrometry: Environmental Science \& Technology, v. 26, no. 12, p. 2440-2447. 
Toms, S.G., Sholar, C.J., and Zettwoch, D.D., 1988, Water-resources data, Kentucky, water year 1987: U.S. Geological Survey Water-Data Report $\mathrm{KY}-87-1,356 \mathrm{p}$.

Tukey, J.W., 1977, Exploratory data analysis: Reading, Mass., Addison-Wesley, $506 \mathrm{p}$.

U.S. Department of Agriculture, 1981, Report for Kentucky River basin:

Lexington, Ky., Economics and Statistics Service, Forest Service, and Soil Conservation Service, in cooperation with Kentucky Soil and Water Conservation Commission, and Kentucky Natural Resources and Environmental Protection Cabinet, 119 p.

U.S. Environmental Protection Agency, 1986, Quality criteria for water, 1986: U.S. Environmental Protection Agency, EPA-440/5-86-011 [variously paged].

1991, Drinking water health advisory--pesticides: Chelsea, Mich., Lewis Publishers, 819 p.

1992, Drinking water regulations and health advisories: Washington, D.C., U.S. Environmental Protection Agency, Office of Drinking Water, $10 \mathrm{p}$.

U.S. Geological Survey, 1986, Land use and land cover digital data from $1: 250,000$ and 1:100,000-scale maps: U.S. Geological Survey Data Users Guide $4,36 \mathrm{p}$.

University of Kentucky, 1993a, Agricultural chemical use impacts on Kentucky groundwater resources--1992 status report: Lexington, Ky., College of Agriculture, $125 \mathrm{p}$.

1993b, Kentucky pesticide user practices and alternatives, 1992: Lexington, Ky., College of Agriculture, $42 \mathrm{p}$.

Veber, K., Zahradnik, J., Brey1, I., and Kred1, F., 1981, Toxic effect and accumulation of atrazine in algae: Bulletin of Environmental

Contamination and Toxicology, v. 27, p. 872-876.

Ward, J.R., and Harr, C.A., eds., 1990, Methods for collection and processing of surface-water and bed-material samples for physical and chemical analyses: U.S. Geological Survey Open-File Report 90-140, 71 p.

Weber, C.I., ed., 1973, Plankton, in Biological field and laboratory methods for measuring the quality of surface waters and discharges: Cincinnati, Ohio, U.S. Environmental Protection Agency, National Environmental Research Center, Office of Research and Development, EPA-670/4-73-001, p. $1-20$.

Wershaw, R.L., Fishman, M.J., Grabbe, R.R., and Lowe, L.E., eds., 1987, Methods for the determination of organic substances in water and fluvial sediments: U.S. Geological Survey Techniques of Water-Resources Investigations, book 5, chap. A3, 80 p. 
White, K.D., Smoot, J.L., Jackson, J.K., and Choquette, A.F., 1987, Surfacewater quality assessment of the Kentucky River basin, Kentucky--project description: U.S. Geological Survey Open-File Report 87-234, 39 p.

Wilber, W.G., and Davis, J.V., 1993, Point versus nonpoint sources of phosphorus in rivers: U.S. Geological Survey Yearbook, Fiscal Year 1993, p. $48-49$.

Wilkinson, Leland, 1989, SYSTAT--the system for statistics: Evanston, I11., $821 \mathrm{p}$.

Witkowski, P.J., Smith, J.A., Fusillo, T.V., and Chiou, C.T., 1987, A review of surface-water sediment fractions and their interactions with persistent manmade organic compounds: U.S. Geological Survey Circular 993, 39 p. 